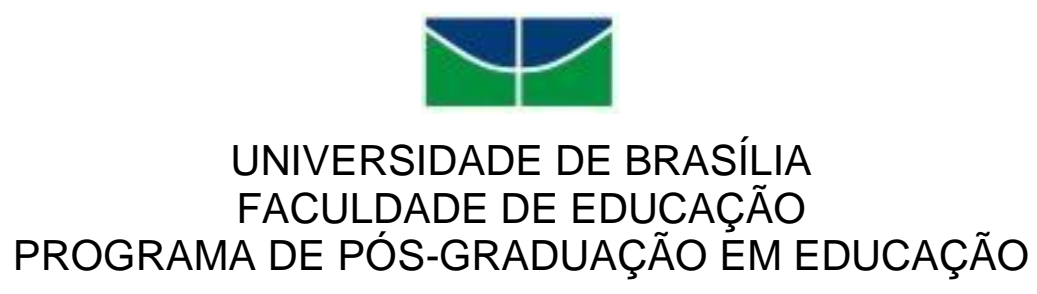

OS INSTITUTOS FEDERAIS DE EDUCAÇÃO, CIÊNCIA E TECNOLOGIA: UMA ANÁLISE DE SUA INSTITUCIONALIDADE

Andréa de Faria Barros Andrade

Brasília, 2014 


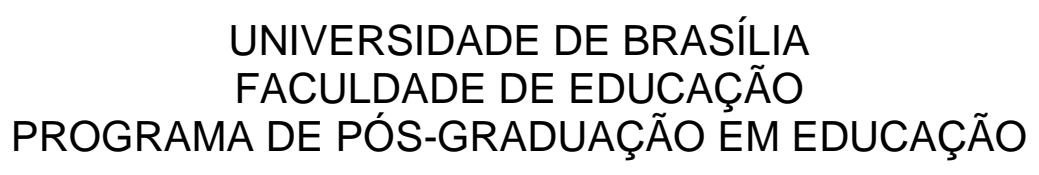

UNIVERSIDADE DE BRASILIA

FACULDADE DE EDUCACC̃O

PROGRAMA DE PÓS-GRADUAÇÃO EM EDUCAÇÃO

\title{
OS INSTITUTOS FEDERAIS DE EDUCAÇÃO, CIÊNCIA E TECNOLOGIA: UMA ANÁLISE DE SUA INSTITUCIONALIDADE
}

\author{
Andréa de Faria Barros Andrade
}

Tese de doutorado apresentada ao programa de Pós-Graduação em educação da Faculdade de Educação da Universidade de Brasília/UnB coo parte dos requisitos para a obtenção de título de Doutora em Educação.

Orientador: Prof. Dr. Bernardo Kipnis 


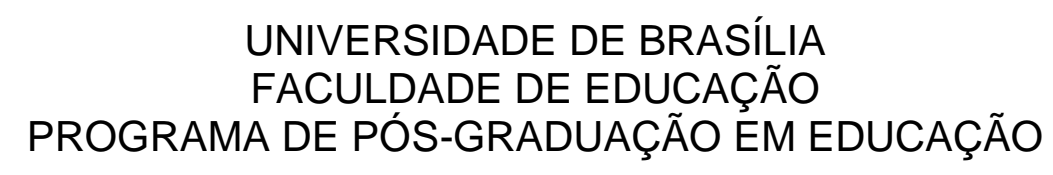

\title{
OS INSTITUTOS FEDERAIS DE EDUCAÇÃO, CIÊNCIA E TECNOLOGIA: UMA ANÁLISE DE SUA INSTITUCIONALIDADE
}

\author{
TESE DE DOUTORADO
}

Andrea de Faria Barros Andrade

Orientador: Prof. Dr. Bernardo Kipnis

Banca:

Prof. Dr. Bernardo Kipnis (UnB)

Profa. Dra. Magda de Lima Lúcio (UnB)

Prof. Dr. Remi Castioni (UnB)

Prof. Dr. Aléssio Trindade de Barros (IFPB)

Prof. Joaquim José Soares Neto (UnB)

Profa. Dra. Olgamir Carvalho - suplente (UnB) 
À minha amada filha Bianca, cujo sorriso iluminou essa jornada. 


\section{AGRADECIMENTOS}

A Deus, que através de seu amor de Pai me concedeu concluir com alegria esse projeto, superando cansaço e agenda complicada.

A Bernardo Kipnis, por sua dedicação comprometimento e paciência na condução da orientação.

Aos professores Aléssio Barros, Remi Castioni, Magda de Lima Lúcio, José Joaquim Soares Neto pelas ricas contribuições a esta pesquisa e pela aceitação em participar de minha banca examinadora.

Ao Eron, com quem divido cotidianamente perplexidades, saberes e esperanças, pelo incentivo e companheirismo na escrita deste trabalho.

A toda minha família pela torcida silenciosa e poderosa e, em especial, a minha sobrinha Priscila, a quem agradeço a companhia na trajetória solitária e ensimesmada da escrita acadêmica.

Por fim, sou também muito grata aos amigos Jorge Messias, Cleunice, Patrícia, Aléssio, Marta, Paulo, Getúlio, Fechine, Jaqueline, Joana, Maria Clara, Marcelo. Desde a ajuda na revisão, liberação de dias de trabalho, incentivo, cobrança até no impedimento de minha desistência, foram demonstrações de carinho, fraternidade e solidariedade inesquecíveis. 


\section{RESUMO}

Os Institutos Federais de Educação, Ciência e Tecnologia configuram-se como de importância substantiva no atual cenário da educação brasileira, com potencial, inclusive, de demarcar, como inovação exitosa, seu modelo de institucionalidade e, a partir da educação profissional e tecnológica, influenciar positivamente o desenvolvimento socioeconômico das regiões onde atuam. Se os Institutos Federais podem ser considerados como uma política inovadora, de que forma a proposição de um modelo teórico pode refletir essa inovação e permitir seu teste empírico e consequente avaliação futura? Esta tese oferece um referencial conceitual, analítico e metodológico sobre a nova institucionalidade da rede federal, contribuindo para o avanço do conhecimento na área via teste de hipóteses, proposição de tipologia de rede política, atlas da oferta, taxonomia dos Institutos Federais e ainda seu modelo teórico o que propiciará subsídios a estudos futuros de avaliação. Dentre as principais hipóteses testadas, destacam-se o fato de que apesar do aumento da titulação dos professores incidir positivamente no aumento da oferta da educação superior, não se confirma que esta ampliação incida negativamente na oferta de cursos técnicos. Adicionalmente, não foi corroborada a hipótese de que o contexto produtivo local, tampouco a especialização do instituto exerce impacto positivo na produção científica. Ademais, esta tese confirmou a hipótese de que o contexto produtivo e a qualidade da infraestrutura laboratorial incidem positivamente na empregabilidade de seus alunos egressos. Por fim, espera-se que a pesquisa contribua para uma melhor compreensão da Rede dos Institutos Federais e seu papel enquanto instrumento de política pública.

Palavras-chave: educação profissional e tecnológica; Institutos Federais; modelos; institucionalidade. 


\begin{abstract}
The Federal Education, Science and Technology Institutes appear as substantive importance in the current scenario of brazilian education, as a successful innovation, in its institutional model, and from the vocational and technological education, positively influence the socio-economic development of the regions where are located. If the Federal Institutes can be considered as an innovative policy, how can theoretical model reflect that innovation and make possible its empirical testing and subsequent further evaluation? This thesis offers a conceptual, analytical and methodological framework on the new institutional arrangements of the federal system, contributing to the advance of knowledge in the area via hypothesis testing, policy network typology proposition, educational atlas, taxonomy of federal institutes and also its theoretical model which provides grants to future evaluation studies. Among the main hypotheses tested, we highlight the fact that despite the upward on academic titration teachers have a positive impact in increasing higher education programs and courses, is not confirmed that this expansion focuses negatively on offering technical degrees. In addition, the hypothesis that the local productive context, nor the institute's specialization has a positive impact on scientific production has not been corroborated. Moreover, this thesis confirmed the hypothesis that the productive context and the quality of laboratory facilities have a positive impact on employability of its students. Finally, it is hoped that this thesis contributes to a better understanding the Federal Institutes system and its role as a public policy instrument.
\end{abstract}

Keywords: vocational education; Federal Institutes; models; institutionalism. 


\section{LISTA DE ABREVIATURAS E SIGLAS}

BID Banco Interamericano de Desenvolvimento

CAPES Coordenação de Aperfeiçoamento de Pessoal de Nível Superior

CEFET Centro Federal de Educação Tecnológica

CES Câmara de Educação Superior

CET Centro de Educação Tecnológica

CFE Conselho Federal de Educação

CNE Conselho Nacional de Educação

CONIF Conselho Nacional de Instituições da Rede Federal de Educação Profissional e Tecnológicac

CP Conselho Pleno

ENADE Exame Nacional de Avaliação de Desempenho de Estudantes

EPT Educação Profissional e Tecnológica

FHC Fernando Henrique Cardoso

FIC Formação Inicial e Continuada

IES Instituição de Ensino Superior

INEP Instituto Nacional de Estudos e Pesquisas Educacionais Anísio Teixeira

IPEA Instituto de Pesquisa Econômica Aplicada

LDB Lei de Diretrizes e Bases da Educação Nacional

MEC Ministério da Educação

RFEPT Rede Federal de Educação Profissional e Tecnológica

SEM Structural Equation Modeling

SEMTEC Secretaria de Educação Média e Tecnológica

SESU Secretaria de Educação Superior

SETEC Secretaria de Educação Profissional e Tecnológica

SINAES Sistema Nacional de Avaliação da Educação Superior

SPSS Statistical Package for Social Sciences 


\section{LISTA DE FIGURAS}

Figura 1-Unidades da Rede Federal de EPT existentes em 2002

Figura 2-Unidades da Rede federal de educação profissional e tecnológica criadas quando da expansão fase I, 2003 - 2010

Figura 3-Unidades da Rede Federal de Educação Profissional e Tecnológica criadas quando da expansão fase I, período 2003-2010.

Figura 4-Unidades da Rede Federal de Educação Profissional e Tecnológica criadas quando da expansão fase II, período 2011-2012.

Figura 5-Total das unidades da Rede Federal de Educação Profissional e Tecnológica .23

Figura 6-Ciclo de Políticas Públicas. 34

Figura 7-Procedimento cíclico para a definição de um modelo causal. .54

Figura 8-Elementos integrantes do modelo EFQM .56

Figura 9-Modelo esquemático de aprendizagem educacional .57

Figura 10-Fluxograma do processo metodológico .75

Figura 12-Mapa das Unidades da Rede Federal com a variável selecionada IDEB 126

Figura 13- Mapa do IDHM dos municípios onde estavam localizados os Institutos Federais existentes em 2013. 128

Figura 14-Mapa do IDHM dos municípios onde estavam localizados os Institutos Federais existentes em 2002 (Pré expansão). 129

Figura 15-Mapa do IDHM dos municípios onde estavam previstos a implantação de Institutos Federais, durante a 1‥ Fase da expansão (2003-2010). 130

Figura 16-Mapa do IDHM dos municípios onde estavam previstos a implantação de Institutos Federais, durante a 2ª . Fase da expansão (2011-2012). 131

Figura 17-Mapa do PIB dos municípios onde estavam localizados os Institutos Federais existentes em 2013.

Figura 18-Mapa do PIB dos municípios onde estavam localizados os Institutos Federais existentes em 2002 (Pré expansão). 134

Figura 19-Mapa do PIB dos municípios onde estavam previstos a implantação de Institutos Federais, durante a 1‥ Fase da expansão (2003-2010). 135

Figura 20-Mapa do PIB dos municípios onde estavam previstos a implantação de Institutos Federais, durante a 2ª ${ }^{\mathrm{a}}$. Fase da expansão (2011-2012). 
Figura 21- Mapa de Distribuição de bolsas PIBID nos Institutos Federais, em 2013.

Figura 22-Mapa de Distribuição de grupos de pesquisa cadastrados na base CNPQ presentes nos Institutos Federais, em 2013.

Figura 23-Representação gráfica das variáveis e suas relações presentes no Inciso I do Art 6을 da Lei Federal no 11.892/2008.

Figura 24-Representação gráfica das variáveis e suas relações presentes nos Incisos I e II do Art 6음 da Lei Federal n 11.892/2008.

Figura 25-Representação gráfica das variáveis e suas relações presentes nos Incisos I, II e III do Art 6ㅇda Lei Federal n 11.892/2008.

Figura 26-Representação gráfica das variáveis e suas relações presentes nos Incisos I, II, III e IV do Art 60 da Lei Federal n 11.892/2008. 145

Figura 27-Representação gráfica das variáveis e suas relações presentes nos Incisos I, II, III, IV e V do Art 60 da Lei Federal n 11.892/2008. 146

Figura 28-Representação gráfica das variáveis e suas relações presentes nos Incisos I, II, III, IV, V e VI do Art 6o da Lei Federal n 11.892/2008.

Figura 29-Representação gráfica das variáveis e suas relações presentes nos Incisos I, II, III, IV, V , VI e VII do Art 6으 da Lei Federal n 11.892/2008. 148 Figura 30-Representação gráfica das variáveis e suas relações presentes nos Incisos I, II, III, IV, V , VI, VII e VIII do Art 6을 da Lei Federal n 11.892/2008. 149 Figura 31-Representação gráfica das variáveis e suas relações presentes nos Incisos I, II, III, IV, V , VI, VII ,VIII e IX do Art 6º da Lei Federal n 11.892/2008. ....150 Figura 32-Representação gráfica das variáveis e suas relações presentes nos Incisos do Art 60 da Lei Federal n 11.892/2008. 151

Figura 33-Modelo para teste de hipóteses 166

Figura 33-Banco de dados desenvolvido no âmbito desta pesquisa 173 


\section{LISTA DE TABELAS}

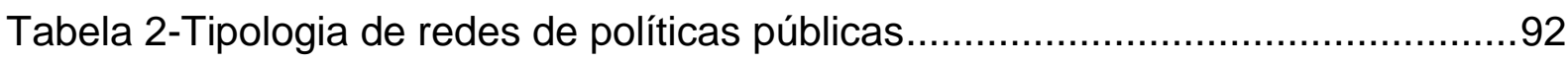

Tabela 3-Taxonomia dos Institutos Federais quanto ao porte .............................100

Tabela 4-Taxonomia dos Institutos Federais quanto à ação educativa ....................101

Tabela 5-Taxonomia dos Institutos Federais quanto ao contexto no qual se insere 103

Tabela 6-Configurações institucionais de origem dos atuais Institutos Federais ....106

Tabela 7-Quantitativo de campi por Institutos Federais .....................................109

Tabela 8-Maior distância entre Sede e Campus dos Institutos Federais ................112

Tabela 9-Titulação do corpo docente nos Institutos Federais. ...............................121

Tabela 10-Definição operacional de variáveis e constructos ...............................167

Tabela 11-Significância das Hipóteses ..........................................................168

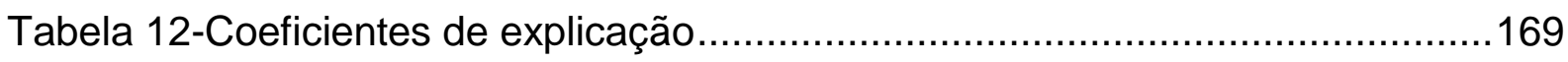

Tabela 13-Teste das Hipóteses...................................................................170

Tabela 9-bases de dados utilizadas na pesquisa .............................................171 


\section{LISTA DE GRÁFICOS}

Gráfico 1-Expansão das unidades dos Institutos Federais de Educação Ciência e Tecnologia no Brasil, período de 2003 a 2014.

Gráfico 2-Expansão das unidades dos Institutos Federais de Educação Ciência e Tecnologia no Brasil, período de 2003 a 2014. .24

Gráfico 3-Evolução de matrículas na Rede Federal de EPT. 26

Gráfico 4-Distribuição de Matrículas por níveis na Rede Federal de Educação Profissional e Tecnológica. .73

Gráfico 5-Distribuição da oferta de cursos por Eixo Tecnológico, em 2013 114 Gráfico 6-Distribuição da oferta de cursos por grupos de Eixos Tecnológicos, em 2013 114

Gráfico 7-Distribuição do grau da oferta de cursos nos Institutos Federais, em 2013 116

Gráfico 8-Distribuição da oferta de cursos técnicos nos Institutos Federais, em 2013

Gráfico 9-Distribuição da oferta de cursos de graduação nos Institutos Federais, em 2013 118

Gráfico 10-Distribuição da proporção de ofertas de cursos técnicos em relação a oferta de cursos de graduação por Instituto Federal, em 2013 119

Gráfico 11-Distribuição da modalidade de oferta (Presencial ou EaD) de cursos nos Institutos Federais, em 2013 120

Gráfico 12-Titulação das funções docentes nos Institutos Federais, em 2013 123

Gráfico 13-Titulação das funções docentes nos Institutos Federais, em 2013 123

Gráfico 14-Funções docentes nos Institutos Federais, por sexo, em 2013 125

Gráfico 15-Técnicos administrativos nos Institutos Federais, por sexo, em 2013 ...125 


\section{SUMÁRIO}

INTRODUÇÃ̃ ...........................................................................................................16

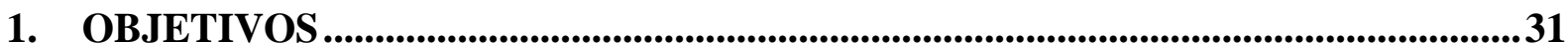

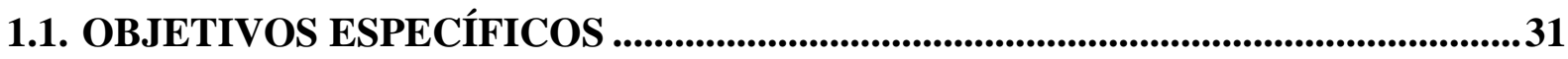

2. REFERENCIAL TEÓRICO..............................................................................32

2.1. O CONCEITO DE POLIÍTICA E O CICLO DE VIDA DAS POLÍTICAS

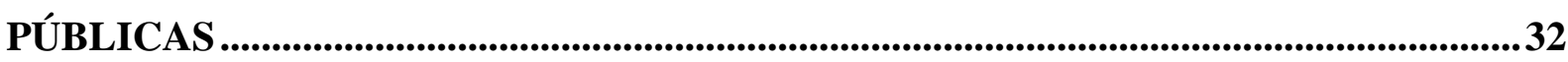

2.2. QUALIDADE NA EDUCAÇÃ̃ .......................................................................35

2.3. AVALIAÇÃO E SUA IMPORTÂNCIA ……………..........................................................42

2.4. INDICADORES SOCIAIS ....................................................................................................46

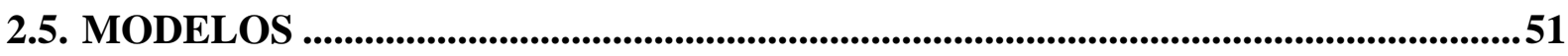

2.6. MODELAGEM DE EQUAÇÕES ESTRUTURAIS.........................................................59

3. SOBRE O OBJETO EMPÍRICO .................................................................................61

3.1. DAS ESCOLAS DE APRENDIZES E ARTÍFICES AOS INSTITUTOS FEDERAIS: CONTEXTO HISTÓRICO E EVOLUÇÃO DA POLÍTICA PÚBLICA ..61

3.2. PERFIS DOS DESTINATÁRIOS DA RFEPT: DOS “DESPROVIDOS DA SORTE E FORTUNA" AOS CIDADÃOS-TRABALHADORES .....................................................64

4. PROCEDIMENTOS METODOLÓGICOS ………...................................................74 
5. HIPÓTESES

6. RESULTADOS .81

6.1. APLICAÇÃO DE UMA TIPOLOGIA DE REDE DE POLÍTICAS PÚBLICAS AO CASO DO CONSELHO NACIONAL DE INSTITUIÇÕES DA REDE FEDERAL DE EDUCAÇÃO PROFISSIONAL E TECNOLÓGICA - CONIF: A REDE DENTRO DA REDE . .81

6.2. REDES DE POLÍTICAS PÚBLICAS 83

6.2.1. O CONSELHO NACIONAL DE INSTITUIÇÕES DA REDE FEDERAL DE EDUCAÇÃO PROFISSIONAL E TECNOLÓGICA - CONIF. .86

6.2.2. PROPOSTA DE TIPOLOGIA DE REDE POLÍTICA. .89

6.3. TAXONOMIA DOS INSTITUTOS FEDERAIS .94

6.4. ATLAS DA REDE FEDERAL DE EDUCAÇÃO PROFISSIONAL E TECNOLÓGICA 105

6.4.1. CATEGORIA DE ANÁLISE: CONFIGURAÇÃO DE ORIGEM .105

6.4.2. CATEGORIA DE ANÁLISE: QUANTIDADE DE CAMPI. 108

6.4.3. CATEGORIA DE ANÁLISE: MAIOR RAIO DE ABRANGÊNCIA. 110

6.4.4. CATEGORIA DE ANÁLISE: GRAUS DE ESPECIALIZAÇÃO DA REDE.113

6.4.5. CATEGORIA DE ANÁLISE: OFERTA EDUCATIVA 115

6.4.6. CATEGORIA DE ANÁLISE: TITULAÇÃO 120

6.4.7. CATEGORIA DE ANÁLISE: IDEB. 126 
6.4.8. CATEGORIA DE ANÁLISE: IDHM

6.4.9. CATEgORIA DE ANÁLISE: PIB .132

6.4.10. CATEGORIA DE ANÁLISE: PIBID 137

6.4.11. CATEGORIA DE ANÁLISE: GRUPO DE PESQUISA CNPQ 139

6.5. MODELO TEÓRICO DAS FINALIDADES DOS INSTITUTOS FEDERAIS DE EDUCAÇÃO, CIÊNCIA E TECNOLOGIA 141

6.5.1. MODELO TEÓRICO DAS FINALIDADES DOS INSTITUTOS FEDERAIS 151

6.5.2. VARIÁVEIS E CONSTRUCTOS: DEFINIÇÃO OPERACIONAL .152

6.6. TESTES DAS HIPÓTESES 166

6.6.1. DISCUSSÃO DAS HIPÓTESES 174

7. CONCLUSÕES .181

8. REFERÊNCIAS .188

9. ANEXO I - DEFINIÇÃO DE CONSTRUCTOS 195

10. ANEXO II - DISTRIBUIÇÃO DA OFERTA DE CURSOS DA EPT NOS INSTITUTOS FEDERAIS EM 2013. 198

11. ANEXO III - ANÁLISE ESTATÍSTICA DAS HIPÓTESES .203 


\section{INTRODUÇÃO}

Nunca entendi o processo de motivação fora da prática, antes da prática. [...] A motivação faz parte da ação. É um momento da própria ação. Isto é, você se motiva à medida que está atuando.

Paulo Freire

Os Institutos Federais de Educação, Ciência e Tecnologia configuram-se como de importância substantiva no atual cenário da educação brasileira, com potencial, inclusive, de demarcar, como inovação exitosa, seu modelo de institucionalidade e, a partir da educação profissional e tecnológica, influenciar positivamente no desenvolvimento socioeconômico das regiões onde atuam. Os Institutos Federais de Educação, Ciência e Tecnologia - ao longo deste trabalho, alternativamente denominados de Institutos Federais - representam mais que um novo modelo institucional, são a expressão maior da atual política pública da educação profissional brasileira (OTRANTO, 2010).

Esses institutos compõem, de forma majoritária ${ }^{1}$, uma rede legalmente institucionalizada - a Rede Federal de Educação Profissional e Tecnológica. São ao todo trinta e oito Institutos Federais de Educação, Ciência e Tecnologia, organizações multicampi, implantadas em todos os Estados da federação, que totalizarão em 2014, 562 unidades escolares, empregando 22 mil docentes e contabilizando um número superior a 1 (um) milhão mil vagas ofertadas (BRASIL, 2010).

\footnotetext{
${ }^{1}$ Compõem, ainda, a Rede Federal de Educação Profissional e Tecnológica os Centros Federais de Educação Tecnológica do Rio de Janeiro e Minas Gerais, Universidade Federal Tecnológica do Paraná e o Colégio Pedro II.
} 
No documento Concepção e Diretrizes: Instituto Federal de Educação, Ciência e Tecnologia, publicado em 2008, o Ministério da Educação revela sua expectativa notadamente relacionada com a inovação e com a ampliação dos requerimentos deste novo formato institucional, utilizando expressões tais como "mudança paradigmática" e "inversão da lógica até então presente". Segundo o documento, os Institutos Federais representariam a materialização de um novo projeto que busca conferir um maior destaque à educação profissional e tecnológica no seio da sociedade, mediante uma ação integrada e referenciada na ocupação e desenvolvimento do território, entendido como lugar de vida (BRASIL, 2010, p. 3).

Machado (2011) também pontua como inovação paradigmática a criação dos Institutos com relação à agenda da educação profissional e tecnológica brasileira - em especial o caráter dessas instituições e à forma de usar os saberes profissionais para responder demandas sociais -, e com relação ao diálogo entre processo de ensino-aprendizagem, pesquisa, extensão e gestão.

Em decorrência de tais configurações, essa rede vem suscitando interesses para pesquisas educacionais, sobretudo, considerando a intensa proposição e implantação de um conjunto de políticas públicas que culminam em reformas educacionais ou programas governamentais que, ora tratam de (re)definições curriculares, de tipos e modalidades de ofertas educacionais, ora focalizam a natureza destas instituições e sua (re)estruturação organizacional, além de sua articulação e integração com outros níveis de ensino e com o setor produtivo (LIMA FILHO, 2009).

Com reconhecido caráter de apoiar a formação para o trabalho, esses institutos foram alvo de reformulação legal em 2008 que definiu nove distintas finalidades, apontando para objetivos educacionais mais abrangentes e um novo leque de responsabilidades institucionais. Dentre elas, destaca-se o incentivo para atuação na oferta de licenciaturas, a intensa interiorização de suas unidades escolares e o desafio de "identificar as parcerias estratégicas, mobilizar ativos locais, explorar potencialidades e oportunidades, a incorporar todos os aspectos das mesorregiões em que se situam: os físico-territoriais, os étnico-culturais, os socioeconômicos e os político-institucionais" (MACHADO , 2011, p. 374). 
A trajetória histórica dos Institutos Federais confere-Ihes especificidades próprias - sobretudo na história recente de expansão relevante para os padrões de política educacional brasileira - que aguçam a necessidade de estudo deste fenômeno social.

A primeira delas diz respeito a sua institucionalidade, transformada por norma legal (BRASIL, 2008). Essa nova institucionalidade não pode ser entendida como uma mera mudança de denominação - como já ocorrido anteriormente - mas, principalmente, como um novo arranjo institucional, que resultou em Institutos Federais constituídos a partir da integração de CEFET, EAF e ETUF ${ }^{2}$ em diversas configurações. Para além do legado patrimonial e imobiliário que cada novo Instituto Federal recebe, deve-se considerar, ainda, que professores e técnicoadministrativos das escolas reunidas passam a integrar um mesmo corpo social dos atuais Institutos, o que agrega um fator de complexidade, qual seja: o convívio de distintas culturas escolares, advindas de história e trajetória escolar peculiares, o que pode se evidenciar quando escolas industriais e urbanas passam a compor com escolas agrícolas e rurais uma nova instituição.

Ademais, de maneira paradoxal, conquanto o marco legal concede aos Institutos autonomia pedagógica, também determina a forma de distribuição de sua oferta educativa - com assertividade -, estipulando percentuais para as vagas ofertadas em licenciatura, 20\% (vinte por cento), 30\% (trinta por cento) para graduações tecnológicas e 50\% (cinquenta por cento) para cursos técnicos. Esta distribuição na oferta educativa do Instituto inspira estudos futuros sobre a configuração proposta face aos novos objetivos estabelecidos e a trajetória de cada Instituto.

A segunda mudança perceptível na Rede Federal de Educação Profissional e Tecnológica é de caráter quantitativo e guarda em si o potencial de conferir a esta rede um novo papel no cenário educacional brasileiro: o expressivo aumento do número de suas unidades de ensino. Em 2002, contabilizando todas as

\footnotetext{
${ }^{2}$ As siglas CEFET, EAF e ETUF significam respectivamente, Centro Federal de Educação Tecnológica CEFET, Escola Agrotécnica Federal - EAF e Escola Técnica vinculada à Universidade Federal.
} 
unidades dos CEFET, EAF e ETUF, a rede federal de educação profissional e tecnológica contemplava 140 unidades de ensino distribuídas em 22 estados brasileiros, atendendo a 120 municípios, vide

Figura 1; de 2003 a 2007, foram implantadas mais 214 unidades, elevando o número total para 354 unidades servindo a 351 municípios (Figura 2). Até o ano 2014, a previsão de expansão estabelece o número de 562 unidades, beneficiando 512 municípios, alcançado em todos os estados da federação (Figura 3 ).

Figura 1-Unidades da Rede Federal de EPT existentes em 2002

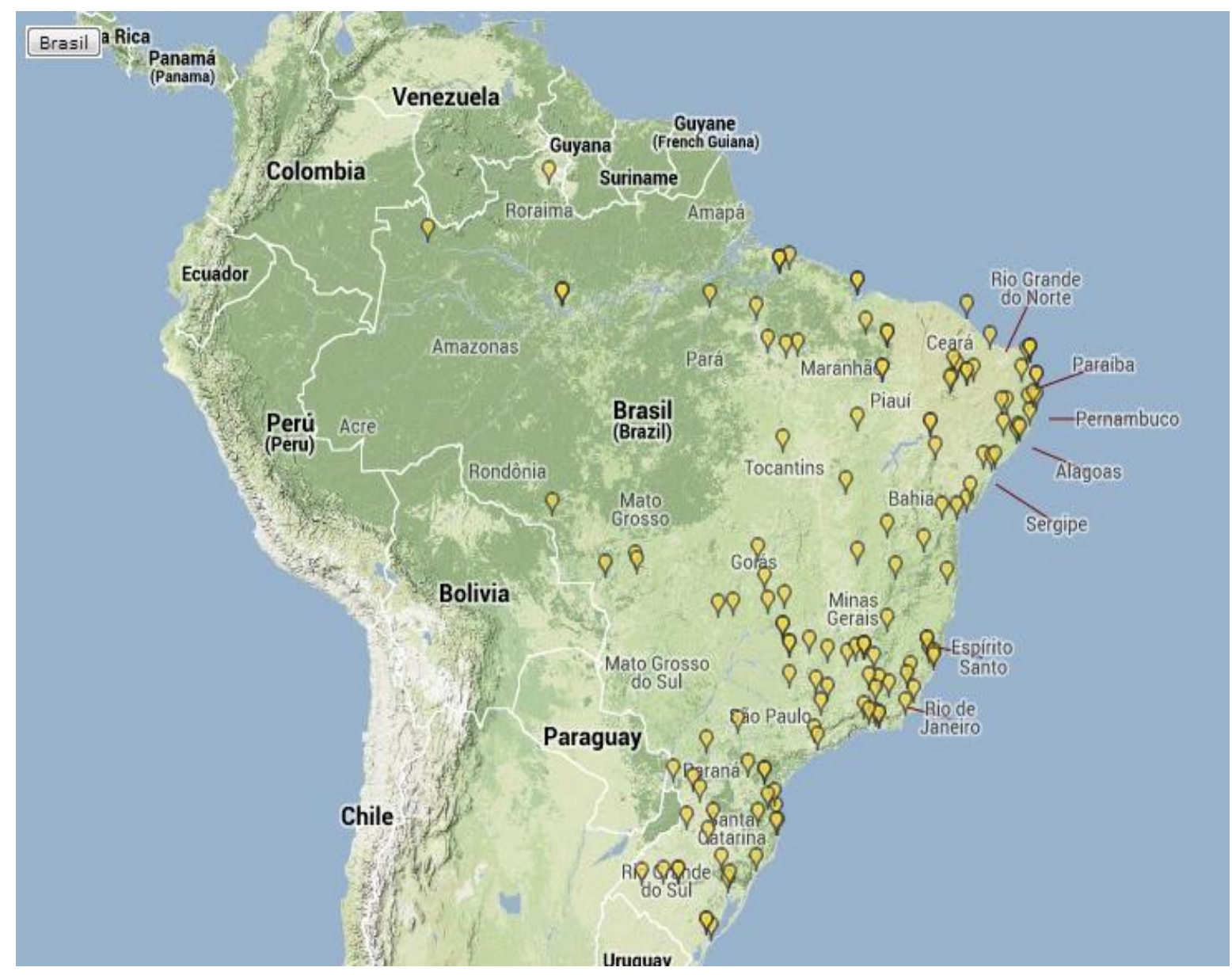

Fonte: SIMEC/MEC 
Figura 2-Unidades da Rede federal de educação profissional e tecnológica criadas quando da expansão fase I, $2003-2010$

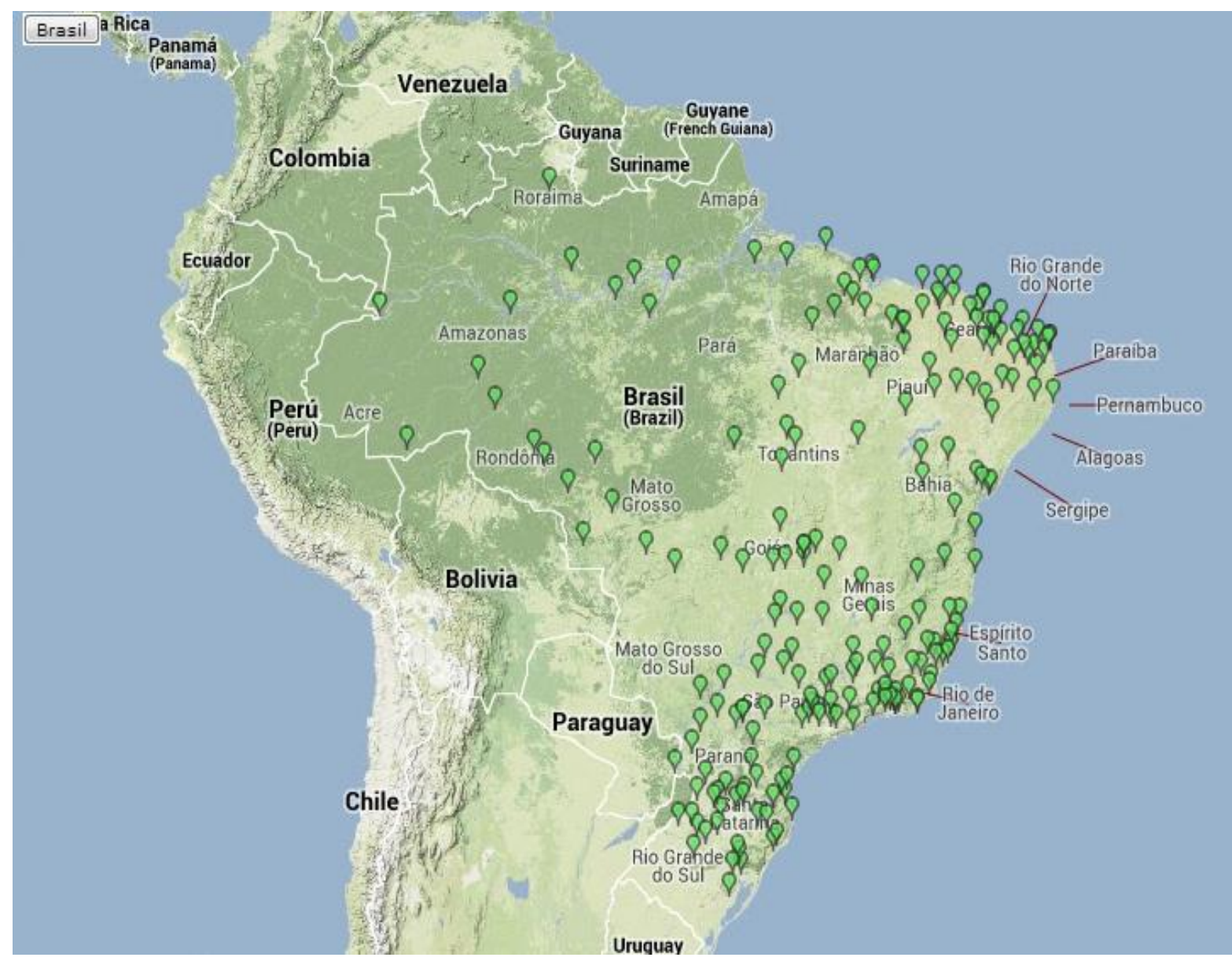

Fonte: SIMEC/MEC 
Figura 3-Unidades da Rede Federal de Educação Profissional e Tecnológica criadas quando da expansão fase I, período 2003-2010.

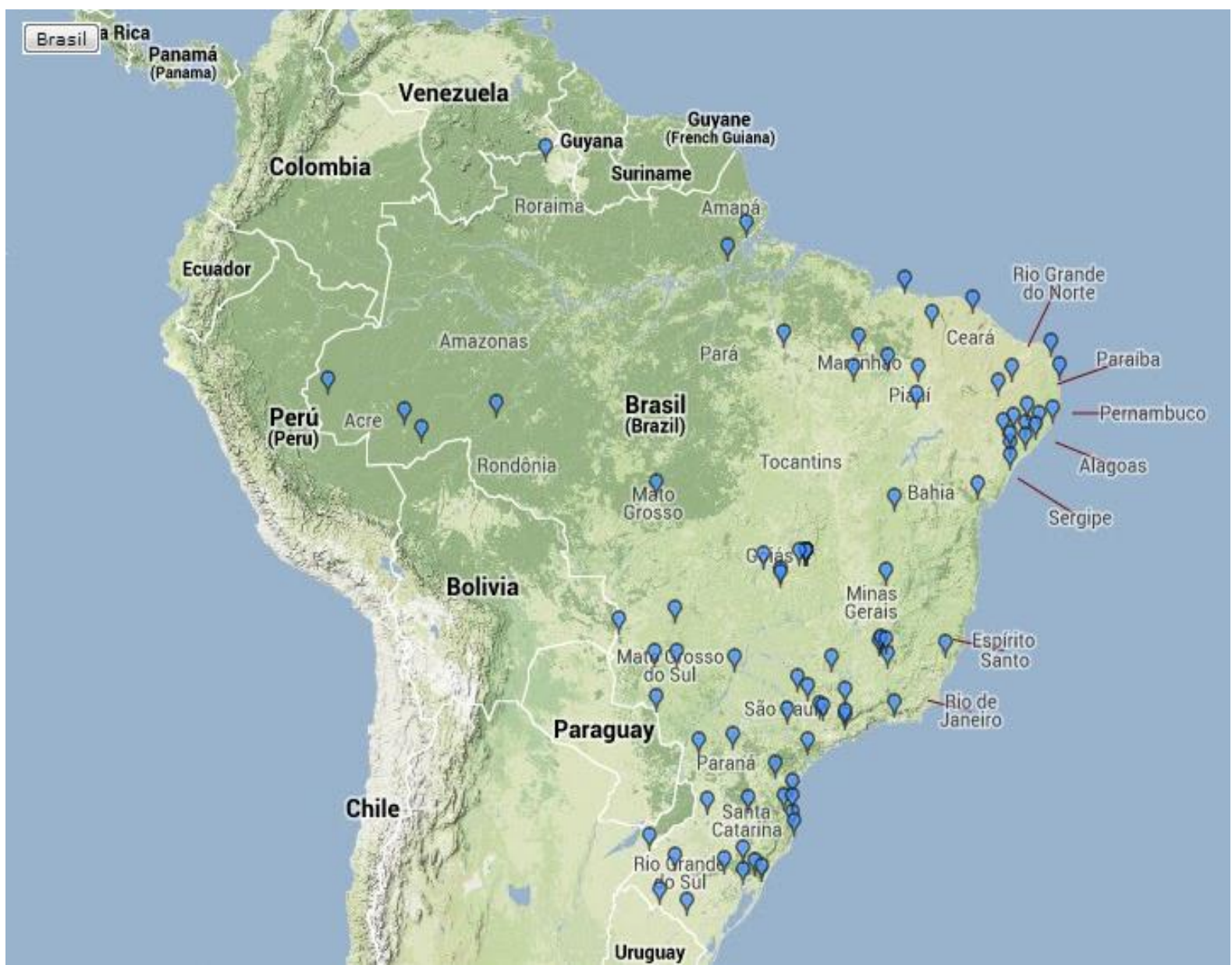

Fonte: SIMEC/MEC 
Figura 4-Unidades da Rede Federal de Educação Profissional e Tecnológica criadas quando da expansão fase II, período 2011-2012.

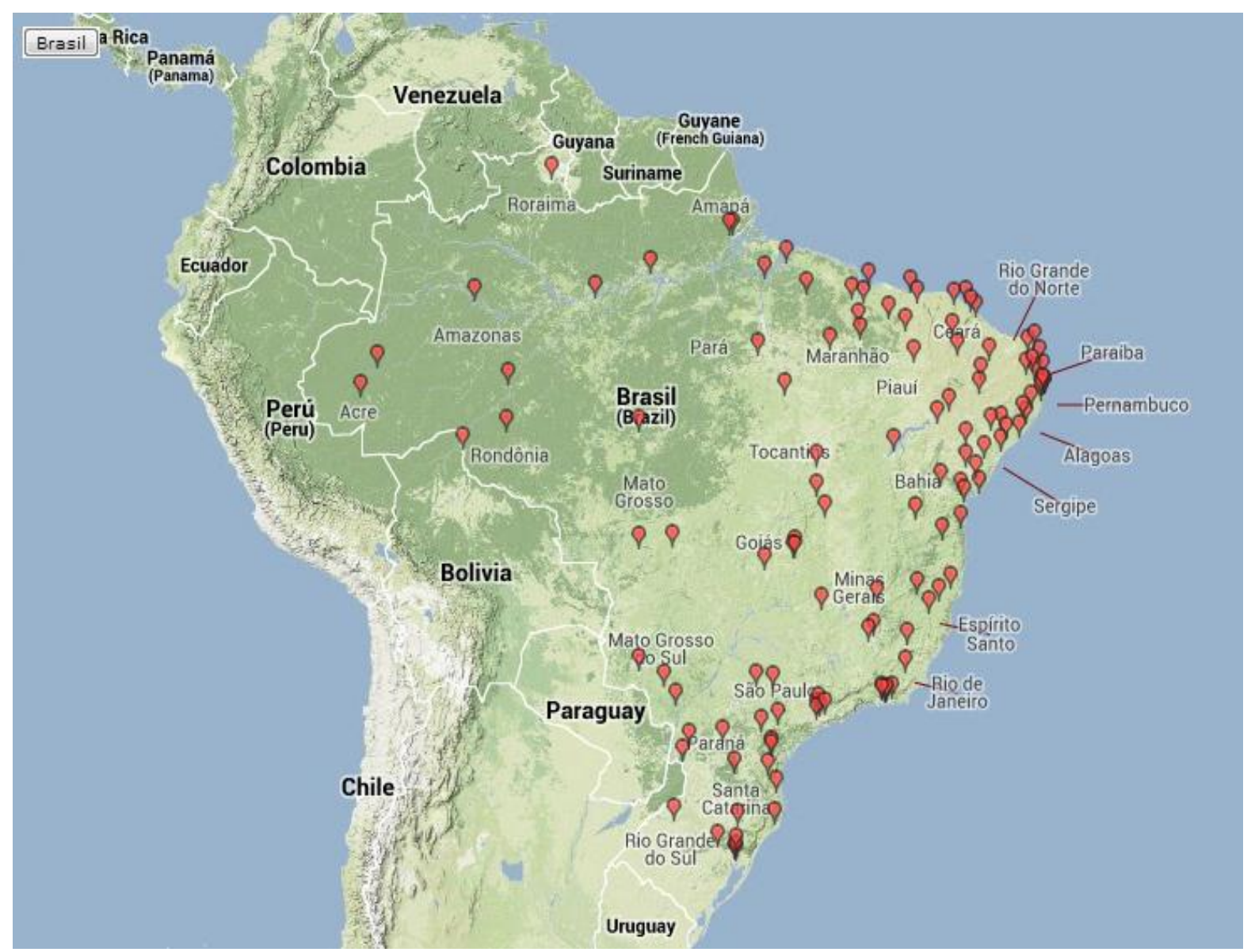

Fonte: SIMEC/MEC 
Figura 5-Total das unidades da Rede Federal de Educação Profissional e Tecnológica.

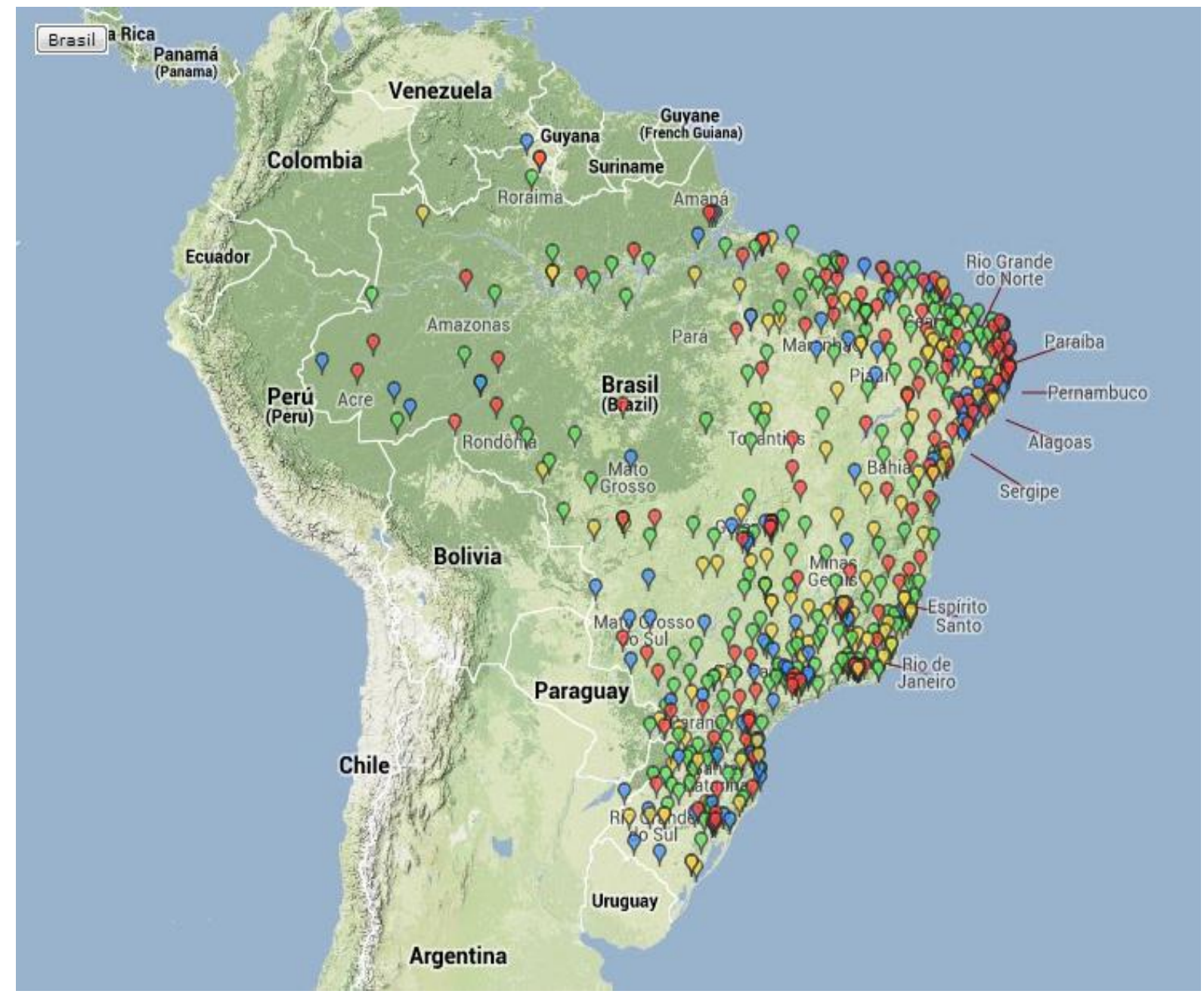

Fonte: SIMEC/MEC

Tais números apontam para um crescimento das unidades escolares de Rede Federal de Educação Profissional e Tecnologia da ordem de 300\% (Gráfico 1) e (Gráfico 2). 
Gráfico 1-Expansão das unidades dos Institutos Federais de Educação Ciência e Tecnologia no Brasil, período de 2003 a 2014.

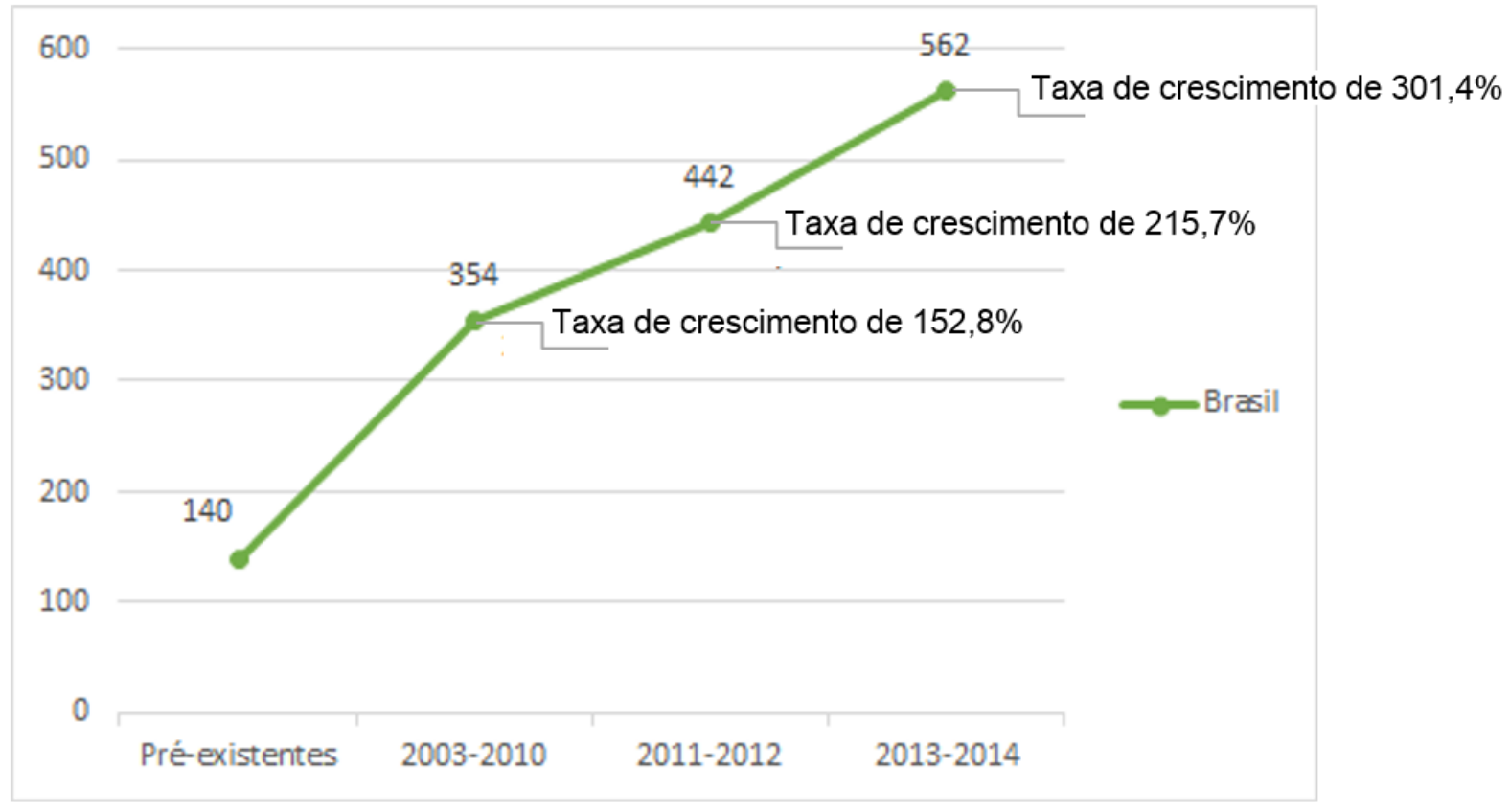

Fonte: MEC/SETEC/SISTEC

Gráfico 2-Expansão das unidades dos Institutos Federais de Educação Ciência e Tecnologia no Brasil, período de 2003 a 2014. 


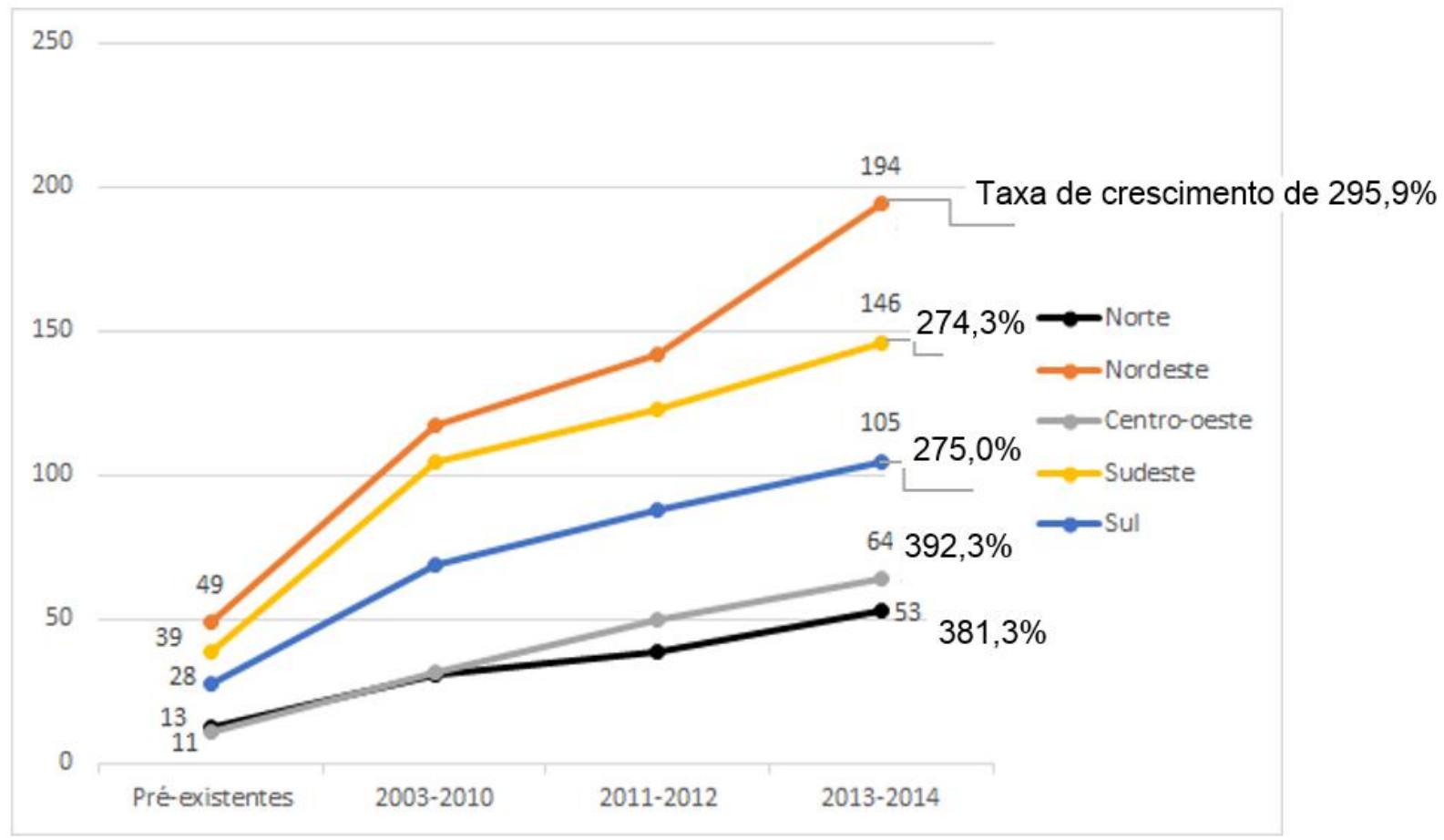

Fonte: MEC/SETEC/SISTEC

Destaca-se neste fenômeno da expansão, o percentual de crescimento da região Centro-Oeste: 392\% (trezentos e noventa e dois por cento), o maior crescimento em termos percentuais, apesar de, em termos quantitativos, a região contar com apenas $1 / 3$ (um terço) do quantitativo de unidades existentes no Nordeste, por exemplo. O maior número de unidades de Institutos Federais instaladas e/ou previstas está na região Nordeste: 194 unidades e o menor número de unidades na região Norte com 53.

Ressalta-se a política de interiorização como uma das características principais da expansão de unidades físicas, posto que apenas 15\% dos campi estarão nas capitais estaduais, além disso, 187 campi estarão em municípios com menos de 50.000 habitantes e, destes, 52 unidades escolares localizam-se em municípios com população inferior a 20.000 habitantes.

Quanto à expansão na oferta educativa, destaca-se o aumento do número de matrículas, que superou, inclusive, a previsão oficial de crescimento estimada pelo Instituto Nacional de Estudos e Pesquisas Educacionais Anísio Teixeira - INEP (Gráfico 3) em 2010. Segundo o INEP, em uma análise de prospecção futura, a Rede Federal de Educação Ciência e Tecnologia alcançaria em 2011 a marca de 
240.000 matrículas em cursos técnicos. Entretanto, em Agosto de 2011, os Institutos Federais registravam, no SISTEC - Sistema Nacional de Informações da Educação Profissional e Tecnológica, o número de 413.362 matrículas em cursos técnicos, $72 \%$ superior ao número projetado.

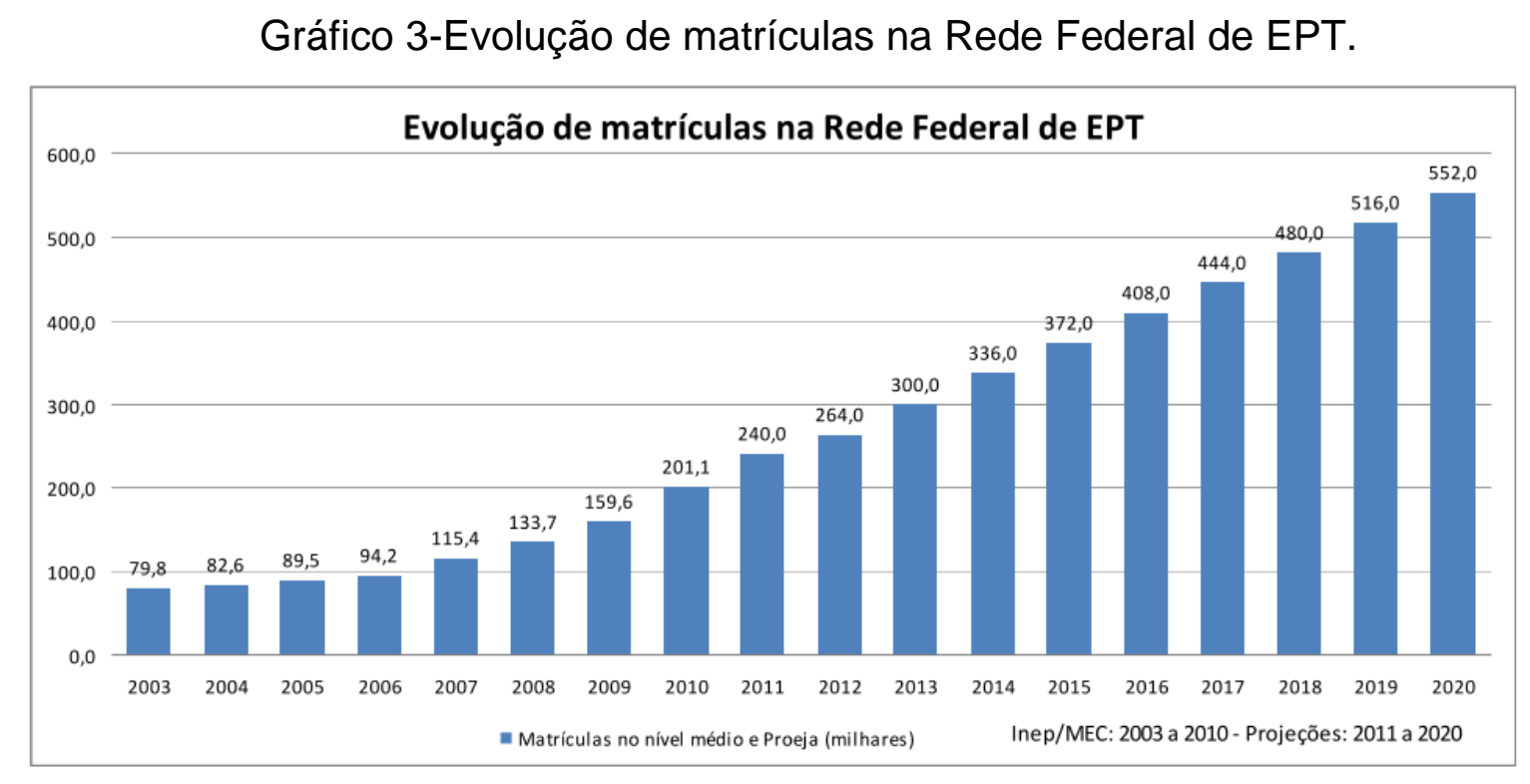

Fonte: INEP/MEC

A expansão também foi percebida no acréscimo expressivo do número de professores e técnicos administrativos recém-contratados, que já supera todo o efetivo docente e administrativo existente à época de sua constituição, sugerindo 
pesquisa futura sobre possível choque de culturas.

Tanto a expansão das unidades escolares quanto a nova institucionalidade atribuída à rede federal resultam da atual política pública para a educação profissional, que entende ser papel do Estado a implantação e manutenção de unidades escolares que objetivem, sobremaneira, atuar desde a formação de técnicos de nível médio até as licenciaturas e cursos de graduação tecnológica. Ressalte-se, porém, que esta política pública apoiada numa visão sobre o papel do Estado, iniciada em 2003 até a atualidade, é antagônica à visão anterior, compreendida no período de 1995 a 2002, que resultou em uma política pública que pode ser caracterizada como desestimuladora da oferta de educação profissional e tecnológica por unidades federais, sendo fomentada - naquele período - por meio de linhas de crédito, a oferta destes cursos em escolas privadas ou mantidas pelos governos estaduais ou municipais.

Além do grande fomento ao crescimento da oferta da educação profissional e tecnológica no segmento privado, a política anterior teve como seu expoente legal a Lei no 9.649/98 (BRASIL, 1998), que, em seu artigo 47, parágrafo quinto, proibia a expansão do sistema federal de educação profissional, verbis:

A expansão da oferta de educação profissional, mediante a criação de novas unidades de ensino por parte da União, somente poderá ocorrer em parceria com Estados, municípios, Distrito Federal, setor produtivo ou organizações não-governamentais, que serão responsáveis pela manutenção e gestão dos estabelecimentos de ensino (BRASIL, 1998).

Desta forma, nos últimos 17 anos, ou seja, em sua história recente, a Rede Federal de Educação Profissional e Tecnológica vivenciou lógicas opostas quanto às políticas públicas planejadas e executadas para este nível da educação, cada uma delas amparadas em pressupostos distintos sobre o papel do Estado e diferentes posições ideológicas. Entretanto, percebe-se um ponto em comum, tanto no período de 1995-2002 quanto no período de 2003-atual: a ausência de esforços no sentido da avaliação da implantação destas políticas públicas.

Torna-se evidente a inexistência de mecanismos institucionalizados de análise e acompanhamento de sua implantação, percebendo-se, ocasionalmente, 
algumas ações de avaliação de aspecto isolado relacionadas a estas políticas, objetivando meramente o cumprimento formal de uma exigência legal, quando, por exemplo, ocorre a prestação de contas de um encerramento de um contrato com organismo internacional. Assim, a despeito destas poucas iniciativas, importa ressaltar que o ciclo das políticas públicas tem resultado incompleto, especialmente no que se refere aos mecanismos de avaliação de sua implantação (ARRETCHE, 1998, p.75).

A avaliação desta política pública possibilitaria formar juízo de valor sobre seu alcance, permitindo propor medidas de correção de rumos, projetar resultados esperados ou mesmo subsidiar as futuras decisões políticas com resultados das ações anteriores. Isso porque, faltando-lhe a avaliação, a política de implantação e expansão dos Institutos Federais não resulta completa, uma vez que por hora, os Institutos Federais são apenas avaliados, no âmbito do SINAES - Sistema Nacional de Avaliação da Educação Superior - quanto à sua oferta educativa de graduação, notadamente minoritária.

Devido às características idiossincráticas da educação profissional e tecnológica, uma eventual reprodução do formato da avaliação da educação superior no segmento de oferta de cursos técnicos de nível médio e de qualificação profissional poderia constituir-se em equívoco ou, no mínimo, em desperdício de utilização de um modelo de avaliação inovador para uma política pública, também, inovadora.

Esse estudo pretende contribuir com esse debate a formulação de um modelo teórico da institucionalidade dos Institutos Federais, cotejando as finalidades elencadas em seu marco legal, com a utilização de indicadores sociais.

A política voltada para a oferta federal pública e gratuita de educação profissional no Brasil teve seu expoente na publicação da lei que institui a Rede Federal de Educação Profissional e Tecnológica - Lei 11.892/2008 - que estabeleceu as finalidades destas instituições, verbis:

Art. 1 Fica instituída, no âmbito do sistema federal de ensino, a Rede Federal de Educação Profissional, Científica e Tecnológica, vinculada ao Ministério da Educação e constituída pelas seguintes instituições: 
I - Institutos Federais de Educação, Ciência e Tecnologia - Institutos Federais;

II - Universidade Tecnológica Federal do Paraná - UTFPR;

III - Centros Federais de Educação Tecnológica Celso Suckow da Fonseca - CEFET-RJ e de Minas Gerais - CEFET-MG;

IV - Escolas Técnicas Vinculadas às Universidades Federais; e

V - Colégio Pedro II.

Este aparato legal fornece a base sobre a qual será elaborado, no âmbito desta pesquisa, um modelo teórico que represente essa estratégia governamental. Ressalta-se que a elaboração do modelo teórico representativo desta política pública, e sua validação por meio de equações estruturais, configura-se como possibilidade de oferecer, aos gestores públicos e pesquisadores, ferramenta que traduza a complexidade e multidimensionalidade dos Institutos Federais, possibilitando a identificação dos aspectos realmente relevantes, orientando pesquisa e investigação futuras que visem o controle e melhoria da qualidade dessas instituições.

Toma-se, assim, como foco do estudo a seguinte questão: Se os Institutos Federais podem ser considerados como uma política inovadora, de que forma a proposição de um modelo teórico pode refletir essa inovação e permitir seu teste empírico e consequente avaliação futura?

Embora tenham sido desenvolvidos estudos recentes sobre a educação profissional e tecnológica e os Institutos Federais, ainda é bastante incipiente, a existência de estudos que envolvam indicadores educacionais ou modelos teóricos que possibilitem análise causal relativos à implantação de políticas públicas nesta área, seja no âmbito da pesquisa quanto da produção bibliográfica.

Outrossim, as políticas públicas são comumente estabelecidas com base em visões pessoais de dirigentes, correntes ideológicas e sem a utilização de informações coletadas sobre a dinâmica anterior - sejam decorrentes de outras políticas ou de diferentes programas implantados - ou seja, quando de sua formulação prescindem de subsídios que poderiam contribuir sobremaneira para sua efetividade. Tal prática decorre de dois problemas interdependentes. O primeiro problema é a incipiente cultura de avaliação - os deliberadores acham que as avaliações feitas são irrelevantes para as decisões que eles tomam. Por sua vez, os tomadores de decisão sentem falta de certas informações de pesquisa que apenas 
raramente são produzidas pelos estudos de avaliação. Os dois problemas têm a mesma origem: o esquema conceitual que orienta a avaliação (SCHNEIDER, 2009, p.311).

No âmbito do MEC não existe mecanismo institucionalizado de avaliação dos Institutos Federais em sua completude. Atualmente, são avaliados parcialmente, ou seja, apenas a dimensão relacionada ao ensino superior está inserida nos procedimentos avaliativos do SINAES e da CAPES. Dimensões relevantes da política pública proposta para a Rede Federal como seu potencial inovador, ensino técnico, formação inicial e continuada estão sem mensuração sistemática, conduzindo a leituras equivocadas ou parciais dos seus objetivos.

Tampouco a mera reprodução de mecanismos de avaliações, atualmente existentes, traduziria a complexidade deste modelo inovador. Assim, diante da abrangência e complexidade da política pública que objetiva o fomento à educação profissional e tecnológica, analisada neste estudo, parece-nos imperativo apontar a necessidade de construção de um modelo teórico que configure os Institutos Federais, com respectivos indicadores que possibilitem avaliar sua implantação, permitindo o avanço do conhecimento acerca dos impactos experimentados, suas possibilidades e limites.

Desta maneira, o escopo da proposição desta pesquisa situa-se num campo do saber relativamente recente, a modelagem prévia ao desenvolvimento, utilização e avaliação de sistemas de indicadores referentes à implantação de políticas públicas, especialmente na educação profissional e tecnológica. Durante o levantamento bibliográfico, foram encontradas apenas duas dissertações de mestrado, defendidas em 2007 e 2008 respectivamente, oriundas de um mesmo programa de pós-graduação em Engenharia da Produção, que abordam aspectos avaliativos associados à gestão dos então denominados CEFET, porém utilizandose de adaptações de abordagens econômicas originalmente propostas para avaliação do desempenho e lucros de empresas privadas, a saber Balanced Scorecard e Análise Envoltória dos Dados (FERREIRA, 2007; COSTA E SILVA, 2008).

Dessa forma, supõe-se como inédita a proposta para a realização deste 
estudo, por abordar os desafios de modelagem e o teste de hipóteses, propondo a utilização de um conjunto de indicadores que capture toda a complexidade da implantação de uma política pública, considerando sua multidimensionalidade e a significância de cada uma de suas dimensões. O conjunto de indicadores a ser construído deverá permitir não apenas sua utilização para a avaliação posterior relativa à implantação dos Institutos Federais bem como, indicar e projetar os impactos e resultados a serem esperados, a partir da implantação desta política.

A utilização de um sistema de indicadores numa política pública em seu estágio inicial e a projeção de seus impactos e resultados - dinâmica, ainda pouco usual, em se tratando da utilização de indicadores - constituem-se em pontos de relevância e da pertinência temporal da pesquisa proposta. Espera-se, ainda, que os resultados da pesquisa possam contribuir para clarificar questões importantes à formulação de políticas públicas referentes à educação profissional e tecnológica, sobretudo, a concepção de estruturas e arranjos organizacionais correspondentes à necessária oferta com qualidade.

\section{OBJETIVOS}

Propor um modelo teórico referente aos Institutos Federais de Educação, Ciência e Tecnologia operacionalizado por indicadores sociais e outros, com finalidades futuras de explicar, predizer e avaliar a realidade da Educação Profissional e Tecnológica no Brasil.

\subsection{OBJETIVOS ESPECÍFICOS}

- Elaborar o modelo de equações estruturais representativo da política pública que constituiu e implantou os Institutos Federais;

- Definir conjunto de indicadores associados às variáveis presentes no modelo teórico formulado; 
- Desenvolver uma tipologia de rede política e da rede de oferta dos Institutos Federais;

- Propor e testar um conjunto de hipóteses relativas às finalidades dos Institutos Federais.

\section{REFERENCIAL TEÓRICO}

\subsection{O CONCEITO DE POLÍtica E $O$ CICLO DE VIDA DAS POLÍTICAS PÚBLICAS}

Inicialmente, convêm destacar a polissemia da palavra "política", o que propicia discordâncias nos diálogos e nos debates, sendo prudente discernir suas principais significações, segundo as categorias propostas por Heidemann (2009, p. 28 e 29).

O primeiro significado apontado por este autor engloba tudo o que diz respeito à vida coletiva das pessoas em sociedade e em suas organizações. Representa esta categoria a clássica frase de Aristóteles: "o homem é um animal político", embora o autor questione tal afirmação, considerando que a política não 
define o homem em sua totalidade, apenas em uma de suas dimensões.

O segundo significado atribuído à palavra política decorre do conjunto de processos e métodos usados por pessoas ou grupos para influenciar, conquistar e manter poder. Ainda segundo Heidemann (2009, op. cit.), esta categoria pode ser ilustrada pelas expressões "entrar na política" ou mesmo, "submundo da política", revelando que nessa acepção interesses conjunturais ou particulares podem comprometer as instituições comuns.

Outra significação apresenta a política como a arte de governar e realizar o bem público, trazendo à tona a ética com que o organismo social deveria ser tratado, numa oposição ao conceito anterior, pois não predominam as vontades das entidades individuais.

O mesmo autor apresenta a acepção operacional da palavra política como: "ações, práticas, diretrizes políticas fundadas em Leis e implantadas como funções de Estado por um governo". Por fim, Heidemann (2009) consolida a sua definição para política como sendo o conhecimento dos fenômenos ligados à regulamentação e ao controle da vida humana em sociedade, como também à organização, ao ordenamento e à administração das jurisdições políticoadministrativas.

Entretanto, surge, mais recentemente, a necessidade de adjetivar a palavra "política" reforçado o seu caráter público, embora, tal caráter não esteja ausente de nenhumas das significações anteriores. Desta forma, entende-se por Políticas Públicas "as ações empreendidas que intencionam a garantia dos direitos sociais, diante de demandas diversas configurando um compromisso público" (IBID, p.31).

Finalizando a conceituação de política pública, torna-se pertinente estabelecer, ainda que brevemente, relação entre estas e o governo. Sob este aspecto, também são percebidas discordâncias, embora mais sutis. Dye (2009, p.101) afirma que existe uma relação íntima entre políticas públicas e instituições governamentais, "estritamente falando, uma política não se transforma em política pública antes que seja adotada, implementada e feita cumprir por alguma instituição governamental". Enquanto que, Heidemann (2009, p. 31) considera que a 
perspectiva de política pública vai além da perspectiva de políticas governamentais, pois não seria o governo a única instituição a servir a comunidade, devendo ser considerado também a atuação em políticas públicas por organizações não governamentais, ou até mesmo por empresas privadas.

Quanto ao ciclo de políticas, são compreendidas ao menos quatro fases: a primeira delas envolve a formulação, ou seja, tomada de decisões políticas visando a resolução da demanda do problema em estudo. A segunda fase envolve a implantação da política formulada, visando dar concretude as ideias para solução do problema-alvo. A fase seguinte deveria contemplar a verificação junto aos atores sociais envolvidos quanto ao atendimento da solução implantada e por fim, a última fase prevê a avaliação da implantação da política pública, cujos resultados deveriam subsidiar tanto possíveis medidas de correção de rumos, quanto futuras decisões políticas.

Bakkes e co-autores (1994) apud Van Bellen (2006, p.57) entendem que a efetividade e racionalidade do processo decisório, em políticas públicas, podem ser melhoradas pela apropriação da informação em todas as partes do processo decisório: identificação do problema, desenvolvimento de política e controle. A seguir apresenta-se o esquema que ilustra o ciclo de políticas públicas:

Figura 6-Ciclo de Políticas Públicas.

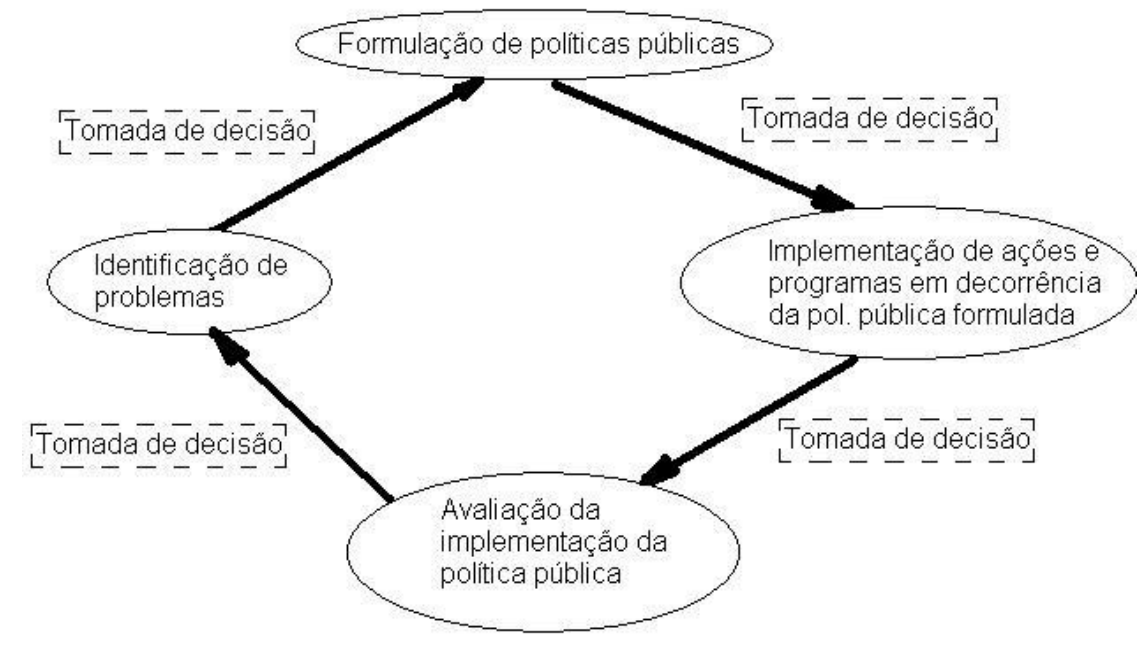

Fonte: Elaboração da autora a partir de revisão da literatura 


\subsection{QUALIDADE NA EDUCAÇÃO}

Um conceito frequentemente vinculado à avaliação - uma das finalidades possíveis de utilização do modelo teórico a ser proposto nesta tese - , é o conceito de qualidade. Nesta seção este conceito será discutido e uma revisão bibliográfica sobre o tema apresentada.

A subjetividade que o conceito de qualidade carrega é razão suficiente para impor a necessidade de clareza conceitual, no sentido de possibilitar saber exatamente ao que se está referindo. Importante ressaltar que o conceito qualidade foi introduzido no campo da educação procedente do mundo econômico, onde a competição, a globalização, a progressiva exigência dos consumidores, praticamente forçaram que produtos e serviços entrassem numa rota de melhoria permanente, para garantir sua sobrevivência no mercado (SARRAMONA, 2004).

Estes antecedentes podem ser tomados como motivo para criticar as propostas de aplicar os princípios da qualidade à educação. Entretanto, segundo Escudero (2002) apud Sarramona (2004, p.8) apenas por essa origem não se pode desqualificar o que uma proposta de qualidade introduz para a educação, com a ressalva de que não se trata de uma atividade que deva estar submetida às estritas normas do mercado, nem seus registros são estritamente econômicos:

\footnotetext{
Para ser mais concreto, os antecedentes economicistas e os contextos ideológicos atuais, com clara preponderância da sociedade neoliberal, podem apontar para a interpretação, entre outras opções, de diretriz de privatização, para deixar a educação sob as estritas leis do mercado, reduzindo ao mínimo a intervenção da administração pública (ESCUDERO, 2002 apud SARRAMONA, 2004, p.8).
}

Combater o conceito de qualidade aplicado à educação sob as fáceis acusações de que se trata de um invento economicista, próprio das mentalidades neoliberais para privatizar e mercantilizar a educação é tão simplista como defender ilusoriamente que agora vamos fazer da educação uma atividade submetida aos mesmos parâmetros de medida e melhoria que a produção de bens industriais.

Sarramona (2004, p.8) defende que a educação não pode opor-se a uma 
corrente geral que demanda melhoria de maneira sistemática e permanente, corrente que afeta a todas as atividades dos países desenvolvidos. Para esse autor, com todas as prevenções necessárias, a atividade educativa deverá entrar - na realidade já o fez - no caminho da análise e da melhoria que supõe a qualidade, sem deixar com isto de seguir questionando a natureza do conceito quando se aplica ao âmbito da educação.

Seguramente há âmbitos profissionais da vida econômica e social
que têm mais clareza do que é qualidade em sua área, do que os
profissionais da educação. Aqui há tanto uma explicação ideológica
como histórica, porque entre os educadores termos como
"competitividade", "otimização de recursos", "eficácia" "prestação de
contas", etc. são vistos com carga semântica negativa, diante da qual
se reage com prevenção; além disto, o campo educativo carece de
tradição de ser submetido a questionamento sistemático a respeito
de seu funcionamento e resultados alcançados (SARRAMONA,
2004, p.8, tradução nossa).

Outro aspecto a ser considerado, diz respeito à associação entre os conceitos de globalização e o de qualidade. Não é necessário forçar muito a comparação para encontrar essa relação, considerando que tem sido a globalização entendida num certo sentido a que tem imposto a exigência de qualidade. A globalização se fundamenta em uma rede de conexões entre atores e elementos que geram informação. Com efeito, a abertura dos mercados em todos os âmbitos, junto com o acesso generalizado à informação e à progressiva tomada de consciência dos cidadãos - também consumidores - fomentou a exigência de qualidade dos produtos e serviços, que estão obrigados a competir entre si para ganhar uma cota do mercado. Porém a globalização concentrou-se especialmente no que conhecemos como "sociedade da informação" e a qualidade inclui a informação de maneira imprescindível: informação diagnóstica (avaliação) como base para conhecer o ponto de partida do processo de melhoria desejado, informação de processos para conhecer como se atua, informação sobre resultados para saber aonde se chegou.

Ninguém negará que a educação tem tradição de avaliação e que se baseia na informação de maneira decisiva. A questão é como utilizar a avaliação não apenas para sancionar o nível de aprendizagem dos alunos, mas para ajuizar o 
conjunto do processo educativo e o conjunto de seus agentes, como referência para a melhoria. O conceito de "qualidade total" tão amplamente empregado no mundo das organizações produtivas, também nos remete a essa perspectiva de totalidade, a essa globalização dos sistemas, ao explicitar que a qualidade em uma organização ou sistema tem de incluir todo o conjunto de elementos e processos. Assim, por exemplo, a preocupação generalizada pela qualidade da gestão das organizações é uma forma de incrementar o valor de seus produtos e serviços, gerando conhecimento sobre si mesma (LOPEZ, 2001 apud SARRAMONA, 2004, p.9). Globalização, integralidade, totalidade, são diversas perspectivas que acabam demandando a qualidade quando se instaura em um contexto. É uma questão de simples coerência com sua natureza de busca de melhoria.

O significado da qualidade tem múltiplas dimensões e perspectivas. Ao exigir uma educação de qualidade se pode demandar coisas tão diversas como a transformação de um modelo cultural, a facilitação de acesso ao mundo do trabalho, o estabelecimento de alguns valores morais, a seleção de uma minoria de excelência o a consecução de padrões instrutivos considerados desejáveis. Inclusive pode ser usada para defender posições políticas opostas.

No campo dos serviços, no qual se situa a educação, há profundas diferenças sobre as metas e as estratégias para alcançar padrões de qualidade. Sarramona (2004, p.10) comenta:

O serviço de hotelaria, por exemplo, pouco tem a ver com o de sanidade ou com o de assistência social. O denominador comum, sem dúvida, é que toda atividade humana é suscetível de melhoria e a educação não se constitui uma exceção. Insistir na necessidade de qualidade da educação é uma forma de mostrar que ela é suscetível de melhoria permanente, a qual inclui, entre outras dimensões, sua adaptação às exigências dos tempos e lugares em que é ofertada (SARRAMONA, 2004, p.10, tradução nossa).

Certamente, em educação um critério de qualidade centrado exclusivamente nos resultados pode levar a desvirtuar a natureza mesma da educação como atividade valiosa por si mesma, de frutos sempre complexos e a longo prazo. Porém, é igualmente certa a necessidade de incorporar as dimensões quantificáveis à definição da qualidade - ainda não que de maneira exclusiva - 
pelas possibilidades que estas oferecem para estabelecer comparações, seja consigo própria ou com os demais. Por tudo isto, parece adequada a proposta de reivindicar um conceito de qualidade educativa que abarque diversas dimensões fundamentais da educação, que combine fatores como equidade e eficiência, coesão social e liberdade, que defenda um conceito de escola para todos e aberta a todos, administrada sob princípios democráticos e na qual estejam envolvidos todos os setores da comunidade escolar (MUNOZ-REPISO \& MURILLO, 2001 apud SARRAMONA, 2004, p.10).

Uma educação que obtenha o máximo rendimento de todos e de cada um de seus alunos, assim como dos recursos materiais e humanos de que disponha, onde a exigência seja uma constante para todos os membros da comunidade educativa, em busca da melhoria permanente. É evidente que são muitos fatores a considerar, aspecto totalmente correspondente ao campo da educação. A busca da qualidade em educação será tão difícil como complexa, pois é da natureza do fenômeno educativo.

Segundo Bertolin $(2005$, p.133) diversas definições de qualidade começaram a surgir durante a década de 1980. Em 1983, Groot afirmou que a qualidade é determinada pelo grau em que um conjunto prévio de objetivos são satisfeitos. Em 1985, C. Ball definiu qualidade como ajuste ao propósito e, pouco depois, qualidade foi discutida em termos da noção de valor agregado por $\mathrm{T}$. Barnett, em 1988, e J. C. McClain, D. W. Krueger e T. Taylor, em 1989 (WATTY, 2005 apud BERTOLIN, 2005, p.132). Durante a década de 1990 surgiram as principais propostas de categorizações das diversas maneiras de se pensar a qualidade em educação.

Na obra Improving Higher Education, o autor Ronald Barnett (1992, p.15), afirma que não é possível formar opinião consistente sobre qualidade em educação sem antes, uma razoável concepção da própria educação. Para o autor, podem ser sumarizados em quatro os conceitos dominantes que embasam abordagens contemporâneas de educação, e trazem as seguintes visões de qualidade, a seguir descritos:

- Educação como produção de recursos humanos qualificados: nesta abordagem a educação é vista como um processo em que estudantes 
são valorados em função da utilidade para o mercado. A qualidade tende a se identificar com as habilidades dos estudantes para a obtenção de sucesso no mundo do trabalho e é aferida por suas taxas de emprego e níveis de retornos econômicos.

- Educação como formação para a carreira de pesquisador: nesta visão a qualidade é medida menos em termos de êxito dos estudantes e mais pelo perfil adequado para a pesquisa. Parte-se da suposição de que a mensuração da relação entre entradas e saídas (a quantidade de ingressos de pesquisas, as publicações realizadas etc.) é o próprio indicador de qualidade educacional.

- Educação como gerenciamento eficiente da oferta de ensino: com a expansão e massificação dos sistemas educacionais, as taxas de custo por aluno obtiveram uma contínua necessidade de redução. Assim, nesta visão, as instituições são entendidas como exitosas, se suas saídas são altas, dadas as fontes a sua disposição. Nela a eficiência está relacionada a quantos estudantes - e em que tempo e a qual custo - são formados pelas escolas e encaminhados ao mercado de trabalho.

- Educação como meio de ampliar as oportunidades na vida: esta concepção está vinculada com os potenciais "clientes" da educação superior. Nela a educação é valorada por sua capacidade de oferecer oportunidades a partir das demandas dos estudantes para desfrute dos benefícios da sociedade moderna.

Ainda sobre o conceito de qualidade, Lee Harvey e Diana Green (1993, p.15) publicaram, talvez a mais difundida proposta de classificação de qualidade em educação. No artigo intitulado "Defining Quality" os autores compilaram a ampla diversidade de concepções existentes em cinco grupos distintos:

- Qualidade como fenômeno excepcional: Aqui, aceita-se como axiomático que qualidade é algo especial. Assim, a noção de qualidade - nesta concepção - costuma estar atrelada à ideia de exclusividade, elitismo ou notória distinção. 
- Qualidade como perfeição ou coerência: Aqui a qualidade se define em termos de atendimento com excelência a um conjunto de itens de conformidade, nela a palavra-chave da qualidade é fidelidade aos padrões, aos standards. Esta concepção está ligada à "cultura da qualidade", que supõe que todo membro da instituição é responsável pela qualidade. Na medida em que reconfigura a excelência em termos de especificações e processo, em detrimento das entradas e saídas, esta concepção "democratiza" e relativiza a qualidade.

- Qualidade como ajuste a um propósito: Aqui somente existe qualidade na medida em que o serviço se ajusta às exigências para cuja satisfação foi concebido e realizado. Trata-se de uma definição funcional da qualidade. Um produto 'perfeito' é totalmente inútil se não serve para satisfazer à necessidade para a qual foi criado.

- Qualidade como relação custo-benefício: embasa esta concepção a ideia de eficiência econômica, ou seja, a ideia de prestação de contas dos custos para os mantenedores é central. Os chamados "indicadores de realização ou rendimento" costumam ser empregados para mensuração nesta concepção.

- Qualidade como transformação: Aqui, a qualidade vincula-se à perspectiva de mudança qualitativa. $O$ professor ou a instituição não faz algo para o cliente, mas faz algo ao cliente, transforma-o. A qualidade estaria, assim, no desenvolvimento das capacidades do aluno e, em possibilitar-Ihe influir na sua própria transformação. $A$ qualidade é tanto o "valor agregado", em termos de incremento de conhecimento, habilidades e destrezas, como também a capacidade de incrementar no aluno a lucidez, a autoconfiança e o pensamento crítico (BERTOLIN 2005, p.139).

Harvey e Green (1993, p.20), após abordar tipificar e classificar os conceitos de qualidade em educação, apresentou, adicionalmente, vantagens e desvantagens da implantação destes.

Tomando-se por base o conceito de qualidade como fenômeno 
excepcional, resultaria na impossibilidade de mensuração. Ora, por tratar-se da ideia da oferta de um produto ou serviço muito especial e distinto - a autora exemplifica citando a Universidade de Harvard - este conceito não teria utilidade para a avaliação da qualidade de outras IES, pois se todas as instituições forem julgadas em comparação à Harvard, provavelmente a maioria seria atestada como de má qualidade (HARVEY e GREEN, 1993, p.20).

A aplicação da mensuração de qualidade, com um ajuste a especificações em sua origem ligada à noção de controle de qualidade na produção industrial. Neste enfoque, a mensuração pode permitir a todas as instituições uma oportunidade para aspirar à qualidade, posto que níveis de standards distintos podem ser fixados para diferentes tipos de instituições.

A mensuração de qualidade como adequação aos objetivos é, notadamente, a definição adotada por muitos analistas e elaboradores de políticas da educação. Desse modo, a qualidade é julgada em termos da extensão em que os objetivos preestabelecidos de um produto ou serviço são logrados. Associa-se a esta definição a noção de dinamismo, visto que os objetivos, certamente, variam e que implicaria na reavaliação das especificações. Por outro lado, Bertolin (2005, p.140) aponta como problema desta definição, a dificuldade de se estabelecer quais deveriam ser os objetivos da educação, visto que representantes de diferentes grupos de interesses na educação podem ter divergentes visões sobre esse tema.

Mensurar qualidade referenciando-se em qualidade como satisfação dos clientes, requer, segundo Harvey e Green (1994, p.21) e Bertolin (2005, p.141) a resposta as seguintes questões: Quem é o cliente da educação? Ele é o usuário do serviço (o estudante) ou é quem paga pelos serviços (o governo, os empregadores)? O estudante é o cliente, o produto ou ambos? Aqui, utilizando-se esta definição, está claro que a adequação aos objetivos está relacionada às necessidades dos clientes. Os críticos deste enfoque questionam se os estudantes estão ou não em condições de saber do que eles necessitam.

Woodhouse (OECD, 1999, p. 29), resume da seguinte forma: "do muito que foi escrito envolvendo o significado de qualidade em educação e das muitas definições sugeridas, a ideia que geralmente é mais aceita está ligada à qualidade 
como "ajuste ao propósito" (fitness for purpose). Este autor, delineia uma visão de qualidade na qual as instituições definiriam seus propósitos em suas missões e seus objetivos, assim a 'qualidade' seria demonstrada pelo alcance deles, o que também possibilitaria a existência de variabilidade de instituições.

Por fim, Lemaitre (2011, p.73), em sua entrevista para o Boletim Técnico do SENAC em 2011, concorda que há múltiplas definições de qualidade, e também, que a mais utilizada, internacionalmente, em processos de mensuração de qualidade é a de 'fitness for purpose', ou seja, o cumprimento das finalidades declarados pela própria Instituição.

No entanto, num contexto de diversidade, esta abordagem deve ser acompanhada por uma análise da relevância dos objetivos. Quando se combinam ambos os olhares - o externo, com relação à pertinência dos objetivos ante as expectativas e demandas do ambiente acadêmico, profissional e social - e o olhar interno, com relação aos princípios e prioridades da missão institucional. Desse modo, obtém-se objetivos relevantes e seu nível de atendimento define a qualidade da instituição (LEMAITRE, 2011, p.73.8, Tradução nossa).

\subsection{AVALIAÇÃO E SUA IMPORTÂNCIA}

Esta seção explorará conceitualmente o tema da avaliação por ser esta uma das principais possibilidades de aplicação do modelo teórico dos Institutos Federais, objeto de estudo desta tese.

Avaliar é uma questão cotidiana. Ao avaliarmos, emitimos juízos de valor sobre alguma ação ou atividade. Na formulação desses juízos, acham-se implícitas as representações que o indivíduo tem do mundo onde vive, do lugar e espaço social que ocupa. Essa forma de olhar, de representar e de valorizar é construída socialmente.

Afirma Sobrinho (2003, p.61-62) sobre esse processo de avaliar espontâneo: 
Assim como estamos sempre fazendo prosa sem nos darmos conta disso, frequentemente avaliamos, usando explicitamente o verbo avaliar ou não. A avaliação é uma palavra hoje largamente utilizada na comunicação cotidiana em vários sentidos e muitas vezes de maneira espontânea, sem que isso geralmente cause inquietações. Contudo, é no campo educacional que ela encontrou seu leito mais fértil, goza de maior força de evocação e experimenta as mais sérias tensões. [...] Mesmo as avaliações tidas como estritamente educacionais em geral concebidas como exclusivamente técnicas, significam muito mais que aquilo que dizem ser, pois produzem efeitos importantes para as políticas que os governos pretendem implementar e para a sociedade em geral. (SOBRINHO, 2003, p.61$62)$.

Sobrinho (2003, p.62) ressalta como esse tipo de avaliação espontânea, enraizada no senso comum, contamina a avaliação sistemática, planejada, técnica e pretensamente objetiva e neutra. Por isto, a importância de avaliar a partir de um modelo teórico que imprima objetividade e garanta segurança na aplicação e confiabilidade nos resultados obtidos.

Neste sentido, afirma Franco (1995, p.24) que para avaliar, torna-se fundamental "o entendimento da atividade humana, da ação prática dos homens, o que pressupõe a análise do motivo e da finalidade dessa ação" (FRANCO, 1995, p.24).

Para Lemaitre (2011, p.73) a avaliação em educação deve ser conduzida referenciando-se na expectativa em torno do alcance dos propósitos institucionais, 0 que favoreceria a legitimação e reconhecimento da diversidade institucional. Se é desejável que num sistema coexistam instituições diversas, não é possível tratar a todas da mesma maneira ou impor-Ihes os mesmos critérios de qualidade, porém a constatação é de que, em geral, os mecanismos de controle de qualidade operam com critérios e procedimentos homogêneos mesmo que em contextos claramente diversificados.

Assim, ainda, segundo Lemaitre (2011, p.73-74) os desafios e riscos a serem enfrentados em processos para assegurar a qualidade nos sistemas educacionais podem ser sintetizados nos seguintes:

- Reconhecimento de que o processo de avaliação é um meio e não um fim. Visto assim, configura-se como um meio para apoiar o 
melhoramento contínuo das instituições e de sua responsabilidade pública com relação à qualidade.

- A necessidade de reconhecimento das mudanças sociais, bem como, as implicações decorrentes para as instituições.

- Considerar a diversidade institucional - distintas missões - e consequente definição de critérios e indicadores de qualidade que respeitem esta diversidade. Aplicar os mesmos critérios a instituições diferentes pode ser contrário ao conceito de qualidade.

- Necessidade de renovação e inovação contínua. Muitas vezes a qualidade é demonstrada precisamente pela capacidade de operar mudanças: novos desafios curriculares, novos métodos pedagógicos, novas formas de organização acadêmica, e que mecanismos são utilizados para apoiar as mudanças requeridas.

- Fomento da auto regulação, ou seja, a capacidade das instituições avançar em suas políticas de auto avaliação e melhoramento contínuo.

- Busca por mecanismos sustentáveis de avaliação, considerando facilidade de coleta, clareza e custos (LEMAITRE, 2011, p.73-74).

Conforme enumera Afonso (2000, p.30) as políticas de avaliação decorreram de aspectos tais como: necessidade de programar mecanismos de controle de resultados e de mensurar o desempenho dos sistemas educativos; necessidade de dispor de um sistema avaliativo concreto, prático e fiável dos resultados da ação administrativa por meio da lógica de gestão empresarial e da necessidade de regulação com base em critérios mínimos de qualidade e eficiência segundo as exigências de mercado.

Ainda sobre o tema, Dias Sobrinho (1997, p.72) considera que a avaliação institucional tem como objeto instituições, sistemas e projetos ou políticas públicas. Segundo o autor, o adjetivo institucional se refere tanto ao objeto quanto ao sujeito da avaliação. O objeto da avaliação é institucional no sentido de considerar a organização educacional em todas as suas dimensões e inter-relações, bem como de contemplar as características de cada organização em respeito à sua identidade. O sujeito da avaliação é institucional no sentido de que os próprios 
componentes da organização educacional e da comunidade acadêmica projetam e realizam a avaliação.

O essencial da avaliação é construir, de forma coerente, um corpo de informações pertinentes, interpretá-las e atribuir-lhes juízos de valor que possam sustentar as articulações de transformação (DIAS SOBRINHO,1997, p.72).

De forma enfática, Sarramona (2004, p.13) afirma que a qualidade decorre, indubitavelmente, da avaliação, seja qual for a situação a ser melhorada. No campo da educação - o sistema educativo em seu conjunto, sendo a escola uma instituição social - a necessidade da avaliação reveste-se de requisitos necessários à prestação de contas à sociedade, ao conhecimento da efetividade de processos administrativos e pedagógicos implantados e, também, a ampliação de condições de participação social, uma vez que, possibilita aos seus beneficiários o direito de conhecer o funcionamento e os resultados obtidos (SARRAMONA, 2004, p.13).

Belloni (2000, p.55) oferece uma consolidação das visões relativas a avaliação institucional, conciliando as principais teorias. Segundo a autora, a avaliação institucional deve buscar compreender a realidade e estar voltada ao processo decisório, tal como estabeleceu Stufflebeam em sua proposta de avaliação voltada para a tomada de decisão; responder a questionamentos na forma de avaliação responsiva desenvolvida por Stake; pode levar à identificação de mérito ou valor, conforme proposto na avaliação de mérito de Scriven, e à avaliação participativa sistematizada por Saul, cuja ênfase está na participação dos sujeitos integrantes da instituição a ser avaliada.

Com relação à avaliação em políticas públicas, a corrente atual dos estudiosos sobre o tema parece ter retirado a ênfase anterior que se centrava no rigor metodológico ou na visibilidade e utilização dos resultados avaliativos produzidos, o que determinaria se "afinal, um determinado estudo compensaria o seu custo". Atualmente, requer-se da avaliação contribuições que possam subsidiar o processo decisório trazendo melhorias à formulação de políticas (SCHNEIDER, 2009, p.325).

Assim, o escopo e objetivos da avaliação são ampliados, o que estende a responsabilidade dos avaliadores, tornando complexa a tarefa de incorporar no 
projeto de pesquisa e nas variáveis do modelo teórico, aspectos da política e respectivos efeitos (se a pesquisa conseguir calcular seu impacto causal) que tenham mais chances de produzir melhores políticas e programas (SCHNEIDER, 2009, p.316). A utilização de indicadores em modelos de análise causal representa hoje os maiores desafios às avaliações de políticas públicas.

Outro desafio imposto à avaliação é a necessidade de transformá-la em cultura, em instrumento usual aos formuladores e atores sociais envolvidos em políticas públicas, assim, coadunando com (SCHNEIDER, 2009, p. 324) "deve-se dar fim à era da avaliação de um tiro só, realizada por grupos externos, que conduzem os estudos com pouco conhecimento da história política e depois deixam o programa sem a capacidade contínua de avaliação".

Neste sentido, o Ministério do Planejamento, Orçamento e Gestão, em seu Guia Metodológico para a construção de indicadores de programas, afirma que o gestor deve ter em mente, desde o início, quando do desenho do programa ou da política pública, que deverão ser mapeadas as demandas de informações necessárias ao monitoramento e avaliação de resultados, a fim de que sejam planejados os processos de captação, tratamento, armazenamento e recuperação dos registros administrativos a serem utilizados na construção dos indicadores. (MPOG, 2010, p.59)

Para além dos aspectos já elencados relativos à avaliação, Lemaitre (2011, p.75) destaca outro afeto à relação existente entre avaliação da qualidade e igualdade.

Não adianta nada garantir o acesso para estudantes, especialmente os mais vulneráveis a uma oferta de má qualidade. Quando a ênfase está na qualidade em todos os níveis e, particularmente, em instituições que lidam com alunos mais vulneráveis - estão a trabalhar para a equidade. Ao mesmo tempo, os sistemas de avaliação devem enfatizar a importância das IES em assumir a responsabilidade para o sucesso nos estudos dos alunos admitidos principalmente aqueles com baixa qualificação e com menos, redes sociais de apoio (LEMAITRE 2011, p. 75.8, tradução nossa).

\subsection{INDICADORES SOCIAIS}


Tal como os astrolábios, que no século XV permitiram orientar a navegação nos mares desconhecidos e descobrir novos mundos, os indicadores - devidamente escolhidos, computados e analisados - podem ser as bússolas a guiar o planejamento público no caminho de um Brasil mais justo e pujante.

(JANUZZI, 2010, p.17)

A relevância da discussão conceitual de indicadores, especificamente indicadores sociais, no âmbito desta tese reside na proposta de sua utilização como insumos, numa perspectiva empírica, ao modelo teórico dos Institutos Federais em desenvolvimento. Ademais a existência de indicadores sociais consolidados referentes ao contexto sócio produtivo no qual se localizam os Institutos Federais igualmente caracteriza-se como ponto de atenção relevante a este estudo.

A etimologia da palavra indicador advém do latim indicare, que significa descobrir, apontar, anunciar ou estimar (HOUAISS, 2009). Sarramona (2004, p.68) define indicador como "um elemento informativo de caráter quantitativo, sobre algum componente ou atributo de uma realidade, objetivando servir de subsídio para elaborar juízo sobre ela". A OECD (1993) apud Van Bellen (2006, p. 42), por sua vez, define indicador como um parâmetro, ou mesmo valor derivado de parâmetros que apontam e fornecem informações sobre o estado de um fenômeno, com uma extensão significativa. Outros autores (CHEVALIER apud VAN BELLEN, 2006, p. 42) expressam um indicador como uma variável que está hipoteticamente relacionada com outra variável estudada, que não pode ser diretamente observada; assim, o indicador seria uma representação de atributo, característica ou propriedade de um sistema, uma abstração deste.

A utilização dos indicadores nas ciências sociais fez surgir a necessidade de qualificá-los com um adjetivo, passam a denominar-se indicadores sociais, embora, em essência ainda mantenham a mesma definição. Jannuzzi (2006, 3.ed, p.15) apresenta uma definição que além de caracterizar o indicador social apresenta algumas possibilidades de sua utilização: 
[...] um indicador social é uma medida em geral quantitativa dotada de significado social substantivo, usado para substituir, quantificar ou operacionalizar um conceito social abstrato, de interesse teórico (para pesquisa acadêmica) ou programático (para formulação de políticas)" (JANNUZZI, 2006, 3.ed, p.15).

Outros autores, assim como Tunstall (1994) apud Van Bellen (2006, p. 43) apresentam cinco grandes funções dos indicadores, quais sejam: avaliação de condições e tendências; comparações entre lugares e situações; avaliação de condições e tendências em relação às metas e aos objetivos; prover informações de advertência; e antecipar futuras condições e tendências. Sublinhando assim, a utilização de indicadores em dinâmicas distintas, avaliação de eventos passados e prospecção de cenários futuros.

Outro aspecto a ser destacado, ainda que sinteticamente, é a utilização de dados primários na construção dos indicadores e a distinção entre eles. Assim, embora muitas vezes um indicador seja apresentado numericamente, estatisticamente ou graficamente, ele é sempre uma composição de dados primários, ou seja, o indicador é uma função de outras variáveis expressas em dados primários, podendo ser esta função extremamente simples ou complexa, resultado de um modelo de simulação (VAN BELLEN, 2006, p.43)

Assim, os indicadores, apesar de não serem a própria realidade, devem ser um modelo desta realidade analiticamente legítimos e construídos dentro de uma metodologia coerente de mensuração. A seguir, uma outra definição para indicadores que acrescenta, aos já enumerados, mais um objetivo para sua utilização: a comunicação e divulgação de resultados.

são sinais referentes a eventos e sistemas complexos. São pedaços de informação que apontam para as características dos sistemas, realçando o que está acontecendo. Os indicadores são utilizados para simplificar informações sobre fenômenos complexos e para tornar a comunicação sobre eles mais compreensível e quantificável (VAN BELLEN, 2006, p. 45).

Entretanto, são necessários cuidados ao se planejar a construção de um sistema de indicadores. Serão listadas abaixo, algumas destas precauções a serem consideradas quando do desenho de indicadores, a partir dos estudos de Meadows (1998) apud Van Bellen (2006, p.56). 
- Devem ser claros no seu conteúdo, devem ser entendíveis, com unidades que façam sentido;

- Devem ser suficientemente elaborados para impulsionar a ação política;

- Devem ser factíveis, isto é, mensuráveis dentro da razoabilidade dos custos e tempo;

- Devem ser suficientes, evitando o excesso de informações ou informações insuficientes para que se obtenha um quadro da situação em medição;

- Devem ser democráticos, ou seja, propiciar acesso às informações obtidas;

- Devem ser suplementares, incluir elementos que as pessoas não possam medir por si;

- Devem ser condutores, ou seja, devem fornecer informações que conduzam à ação; e

- Devem ser provocativos, levando à discussão, ao aprendizado e à mudança.

Operacionalmente, os indicadores costumam ser construídos a partir das dimensões conceituais componentes do objeto ou situação a ser conhecida. Assim um indicador educacional, por exemplo, pode contemplar as dimensões referentes aos alunos, recursos e instalações físicas, resultados obtidos em exames nacionais, articulações e parcerias com o entorno produtivo, ou ainda, contemplar dimensão relativa ao processo de gestão. A seleção das dimensões componentes de um indicador deve atender, fundamentalmente, ao objetivo da mensuração.

Acredita-se que o processo de gestão é enriquecido com a mensuração. O processo decisório, a gestão operacional e o controle de implantação de programas e políticas públicas necessitam de novas maneiras de medição de suas fases numa realidade complexa e multivariada, assim os indicadores podem constituir-se numa importante ferramenta. Por fim, 
uma realidade dinâmica. As medidas fornecem uma base empírica e quantitativa de avaliação de performace e permitem comparações no tempo e no espaço, proporcionando oportunidades para descobrir novas correlações (VAN BELLEN, 2006, p. 54).

Faz necessário, entretanto, ressalvar que a construção e decorrente utilização de indicadores acarretam, de forma não rara, desconforto à comunidade produtora de dados. Isto acontece, pois a redução de uma complexa e dinâmica realidade a um número implica em série de reduções e simplificações, difíceis de serem percebidas pelo senso comum, ou pela não divulgação concomitante do modelo utilizado.

Contudo, não obstante estas críticas, é inegável a importância de indicadores sociais, no acompanhamento de programas e até junto à opinião pública, sendo o exemplo mais clássico, o IDH (Índice de Desenvolvimento Humano) que se revelou em medida catalisadora, na discussão de temas sociais.

o índice imperfeito falou alto e claro e recebeu uma atenção inteligente e, através desse veículo, a realidade complexa contida no Relatório encontrou também uma audiência interessada (PNUD, 1998, p.5).

O emprego de indicadores para referenciar a qualidade de um sistema educativo sempre gera polêmica. $O$ ponto principal é o argumento de que o indicador provê uma ideia do estado do item avaliado, sem, porém explicar os porquês geradores das situações; além do argumento de que resultam em simplificações da realidade e que não resultam uteis para a melhoria das instituições. Por sua vez, o argumento a favor dos indicadores aponta para a necessidade de objetivar parâmetros educativos de carácter geral, que permitam comparações entre países e que permitam aos gestores do sistema decisões mais acertadas (BOTTANI, 2001 apud SARRAMONA, 2004, p.70). Neste sentido, afirmase que a opção pela utilização de indicadores está condicionada a sua destinação posterior (PEREZ, 2002, p.65).

De forma positiva, os indicadores permitem estabelecer comparações, advertir tendências de caráter interno e a obtenção de séries temporais. Sarramona (2004, p.72) cita a título de exemplo, os resultados obtidos em provas de leitura realizadas, na Europa, em 1991 e repetidos dez anos depois no mesmo grupo de 
países, o que permitiu averiguar os avanços e retrocessos produzidos na área durante esse período.

A título de conclusão sobre a polêmica em torno do tema, Sarrramone (2004, p.74), afirma que

As críticas obrigam a uma revisão constante dos indicadores e, consequentemente, um desejo, incessante, de avaliação e comparação de parâmetros referidos, com maior ou menor grau de acerto, como indicadores de qualidade (SARRAMONA, 2004, p.74, tradução nossa).

\subsection{MODELOS}

A construção de modelos é um processo inerente ao sistema cognitivo humano na sua busca por compreender o universo que o cerca (VOSNIADOU, 2002). O homem constrói modelos mentais que representam aspectos tanto do mundo físico quanto do social, e manipula esses modelos ao pensar, planejar e tentar explicar eventos desse mundo. No processo de aquisição e construção de conhecimento os modelos estão, quase sempre, presentes.

Entre cientistas e filósofos da ciência, a importância de modelos é bastante reconhecida, tendo sido a teoria dos modelos, originalmente, uma teoria da ciência. Os modelos estão no centro de qualquer teoria e a construção e emprego de modelos é fundamental no processo da pesquisa científica (HALLOUN, 2004). Ferramentas relevantes usadas pelos cientistas na produção do conhecimento e um dos principais produtos da ciência, pode-se considerar que o desenvolvimento do conhecimento científico relativo a qualquer fenômeno relaciona-se normalmente com a produção de uma série de modelos com diferentes abrangências e poder de predição.

Em ciências, um modelo pode ser definido como uma representação parcial de um objeto, evento, processo ou ideia que é produzida com propósitos específicos como, por exemplo, facilitar a visualização, fundamentar a elaboração e 
teste de novas ideias, possibilitar a elaboração de explicações e previsões sobre comportamentos e propriedades do sistema modelado (GILBERT, BOULTER \& ELMER, 2000). Em adição ao colocado por esses autores a importância em modelar uma realidade passa por estabelecer relações hipotéticas entre constructos, que permitam explicar e predizer a realidade, em nível teórico; obter um retrato mais sintético e inteligível de uma realidade mais complexa e pouco sistematizada em sua abrangência; poder passar do mundo teórico para o mundo empírico, a medida em que se operacionaliza constructos; a modelagem serve também aos propósitos de uma avaliação e monitoramento da realidade, ao se comparar os resultados alcançados com metas estabelecidas; e serve também como suporte técnico e racional para tomada de decisão.

A modelagem de uma realidade também possui suas limitações e restrições entre elas pode-se citar: a simplificação poderá deixar de lado outras características da realidade não captadas em sua complexidade; a linearidade das relações limita o alcance de outras possibilidades relacionais próprias de uma realidade complexa; um modelo deixa de lado a captação da realidade subjetiva dos sujeitos, sua interpretação e complexidade, cujo conhecimento continua importante na compreensão de uma determinada realidade focada em uma política pública.

A necessidade de combinar modularmente teorias parciais e mecanismos causais sob a forma de um modelo advém da impossibilidade de dedução de hipóteses de trabalho de teorias abrangentes. Dessa forma, o desenvolvimento de modelos é essencial aos estudos de caso, porque organizam a percepção sobre o conhecimento esperado, modelando questões e selecionando variáveis e fatores com alto potencial explicativo. Embora seja mais reduzido que uma teoria completa, um modelo proporciona uma linguagem pictórica descritiva mais amigável que as formulações dos pesquisadores e, dessa forma, mais útil à comparação de pressupostos e hipóteses entre diferentes casos em análise.

Por isso, diante da dificuldade, ou até da impossibilidade, de se elaborarem teorias empiricamente validadas, a solução aponta ao desenvolvimento de modelos causais a partir do qual hipóteses possam ser enunciadas e, por conseguinte, a análise dos casos possa ser conduzida a partir das narrativas. 
Uma vez que não podemos depender de teorias que formulam 'regularidades do tipo leis gerais' para explicar fenômenos sociais complexos, deveríamos relaxar o critério de abrangência e trabalhar com 'mecanismos de pequeno ou médio porte'. Mas isso também implica que as explicações completas, que não obstante devem ser buscadas, só possam ser construtos modulares, combinando e relacionando vários 'módulos' teóricos que dêem conta de explicar fenômenos ou eventos complexos únicos empriricamente observáveis. As ligações entre os módulos bem poderiam ser narrativas ou ter o caráter de teorias parciais. (SCHARPF, 1997, p.30-31).

A construção de um modelo com um mecanismo causal, expressando uma teoria parcial, serve adequadamente ao propósito de explicar os casos em análise. Contudo, sua utilização para explicar categorias mais abrangentes de fenômenos, como conjuntos de políticas públicas ou governos, deve ser tratada, similarmente, de forma modular, incorporando outras construções causais e relacionais unidas por narrativas.

A complexidade da mensuração associada à avaliação relaciona-se com a necessidade de desenvolvimento de um modelo que simplifique a realidade, capturando a multidimensionalidade de uma escola ou sistema educativo sem reduzir a significância de cada um dos escopos utilizados no sistema. Desta forma, o desenvolvimento de um modelo que expresse as possíveis relações entre as variáveis e que traduza tal complexidade é vital para a atividade de avaliação, para a comunicação dos resultados obtidos e para o avanço do conhecimento científico sobre o assunto.

Em se tratando de indicadores sociais, devem ser propostos modelos teóricos que apresentem as relações entre um conjunto de variáveis, fornecendo, para teste, uma explicação sobre um fenômeno particular ainda que amplo (KERLINGER, 1980, p. 17). Assim, a teoria sobre o fenômeno que se deseja modelar desempenha um papel fundamental no processo de modelagem porque subsidia os relacionamentos, ou seja, facilita a identificação e representação das possibilidades de relações entre as variáveis, sendo os indicadores apenas a mensuração da teoria consubstanciada pelo modelo teórico e hipotético.

Sobre esses aspectos discorrem Ferreira e Vieira (2010, p. 248), afirmado que: 
(...) não podemos esquecer que os indicadores precisam ser considerados em função dos seus limites e possibilidades como identificadores de recortes da realidade que se pretende avaliar. Só relativizando os modelos de avaliação adotados é que poderemos pensar em possíveis cruzamentos e articulações que favoreçam a construção de olhares sob os diversos aspectos e resultados encontrados (...), já que todos os modelos se revelam parciais.

Diferentemente da realidade, onde causas e efeitos existem independentemente de como elas se relacionam, nos modelos, as causas e efeitos dependem totalmente do modo pelo qual os relacionamentos são especificados (ANJOS NETO, 2003, p.78).

A seguir, apresenta-se um diagrama esquemático do ciclo de desenvolvimento e validação de um modelo teórico-hipotético (Figura 7), segundo MacRae (1985, p.105). Importa destacar que no diagrama apresentado, a seguir as fases de desenvolvimento de modelos devem ser sempre apoiadas no referencial conceitual do objeto em estudo e, principalmente, estão previstas ações de retroalimentação em busca de melhorias ao modelo inicialmente estabelecido.

Figura 7-Procedimento cíclico para a definição de um modelo causal

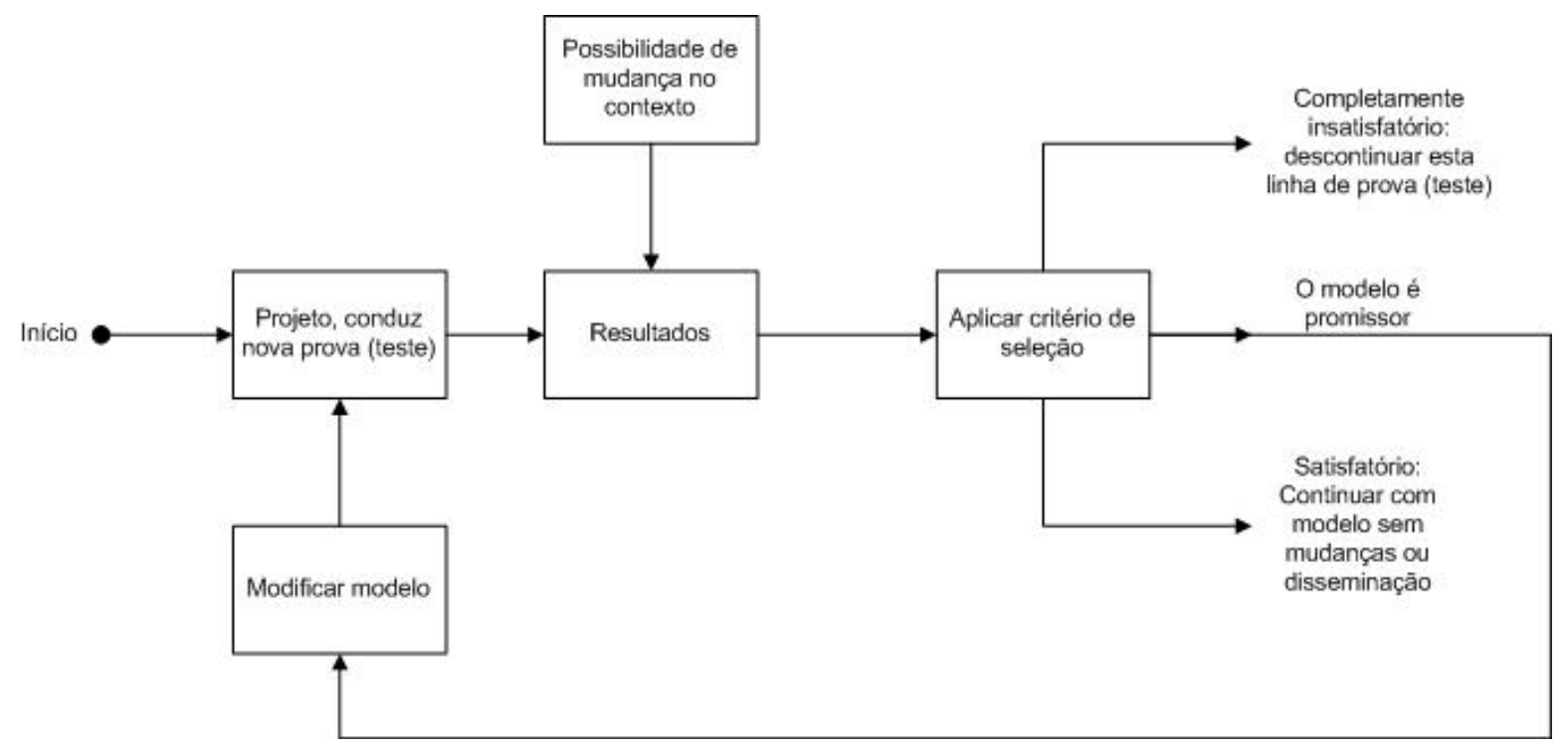

Fonte: Policy Indicator: links between social science and public debate. (MACRAE 1985, p. 105, tradução nossa). 
Em síntese, o esquema trata da proposição de uma versão inicial do modelo causal, posteriormente submetida a testes e validação, cujos resultados deste procedimento irão corroborar o modelo proposto, descartá-lo por completo, ou de forma mais usual, conduzir a melhorias sucessivas - após o exame das falhas e críticas - configurando a retroalimentação apresentada.

Importa ressaltar as linhas de setas, neste tipo de esquema supra, apenas indicam sequência de passos. Posteriormente, no âmbito dos modelos propostos neste estudo, as setas indicarão possível relação causal entre variáveis.

Quanto às finalidades que um modelo deve atender, Dye (2009, p. $126 \mathrm{e}$ 127) enumera seis delas: (i) ordenar e simplificar a realidade; (ii) identificar aspectos realmente relevantes; (iii) condizer com a realidade; (iv) comunicar algo significativo; (v) orientar a pesquisa e investigação; e (vi) propor explicações.

Assim, de modo prático e do ponto de vista esquemático, observa-se no modelo o desenho de possíveis relações de causa-efeito entre variáveis para uma composição de hipóteses. Os relacionamentos dentro desta composição são descritos pela magnitude do efeito (direto ou indireto) que as variáveis independentes (observada ou latentes) têm nas variáveis dependentes (observada ou latentes) (HERSHBERGER, MARCOULIDES, \& PARRAMORE, 2003).

Define-se como variável exógena ou independente aquela preditora ou "causadora" de um efeito em outra variável/construto no modelo teórico. Enquanto que a variável dependente ou endógena é aquela que resulta de pelo menos uma relação causal.

Hair Jr et al (2005) considera como construto ou variável latente aquelas variáveis que não podem ser diretamente medidas, mas que podem ser representadas por outros indicadores, constituídos pelos itens das escalas ou pela observação do pesquisador, que em conjunto permitirão que ele obtenha uma medida razoavelmente precisa da atitude.

Frente a esta multiplicidade de dados, há que se considerar que as instituições escolares costumam contar com uma ampla gama de instrumentos de avaliação, alguns deles empregados por autoridade regulatória ou de inspeção 
educativa - usualmente utilizada quando da avaliação externa - bem como outros gerados especialmente para atendimento à auto avaliação. Ainda importa destacar que as instituições educativas podem recorrer, igualmente, a outros sistemas de indicadores específicos (demográficos, econômicos), que enriqueceriam tanto a avaliação interna quanto a externa (BARBERÁ, 1990; COROMINAS E OUTROS, 1992; CHAVARRÍA E BORREL, 1999).

A seguir serão apresentados dois usos de modelos com finalidades distintas. O primeiro do EFQM (European Foundation for Quality Management) é um modelo para avaliação de qualidade do ensino e aprendizagem com aplicação na gestão da qualidade nas instituições de ensino, não tenciona constituir-se numa teoria. O modelo seguinte, o proposto por MacRae, representa um modelo teórico explicativo sobre o aprendizado, com suas respectivas hipóteses.

No plano internacional, um modelo de avaliação de qualidade muito difundido - no âmbito da Educação Profissional e Tecnológica - é o denominado EFQM (European Foundation for Quality Management), estabelecido em 1992 pela Fundação Européia para a Gestão da Qualidade (htpp://www.efgm.org). Este modelo tem dois objetivos básicos: estimular e ajudar as instituições educacionais a participar em atividades de melhoria do seu processo educativo, bem como transformar a gestão de qualidade em um objetivo da instituição. A seguir, segue o esquema (

Figura 8):

Figura 8-Elementos integrantes do modelo EFQM 


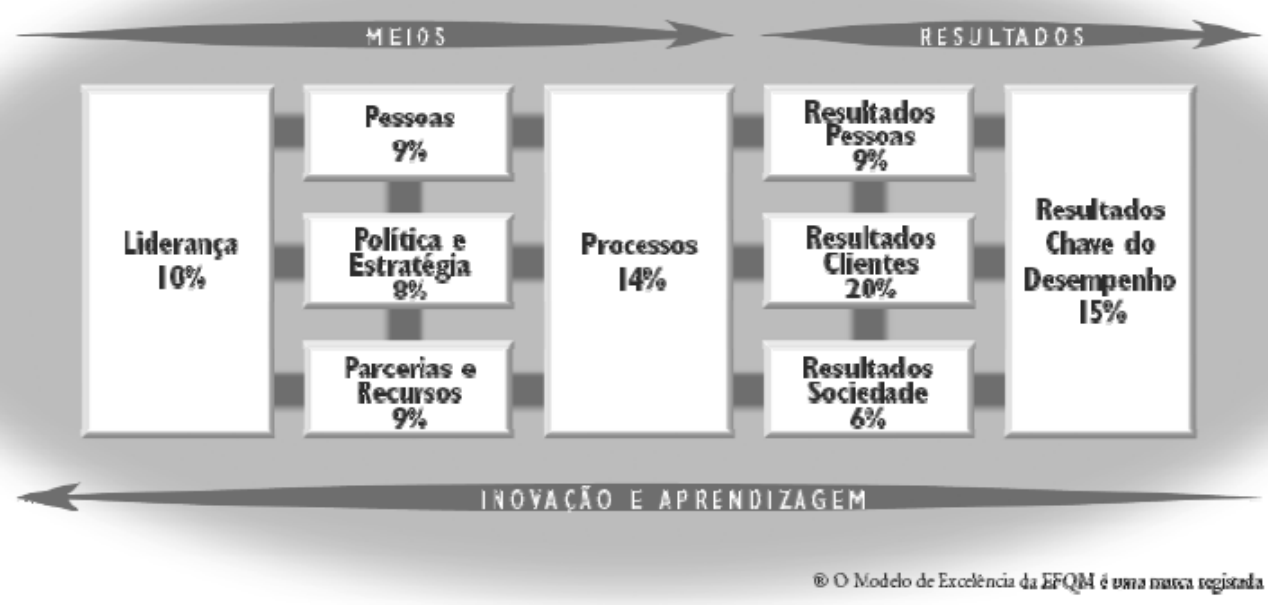

Fonte: Factores e indicadores de calidad en la educación. (SARRAMONA 2004, p. 120).

Por sua vez, o estudo de MacRae (1985, pág 132), "Policy Indicator: links between social science and public debate", obra de referência no desenvolvimento de modelos hipotético-teóricos no campo social, apresenta uma estrutura de modelo relativa ao aprendizado do aluno, ou, aos efeitos produzidos pela escola. Neste modelo, as principais variáveis e suas possíveis relações incidentes no aprendizado estão expostas com duas importantes inovações, vide Figura 9.

Figura 9-Modelo esquemático de aprendizagem educacional 


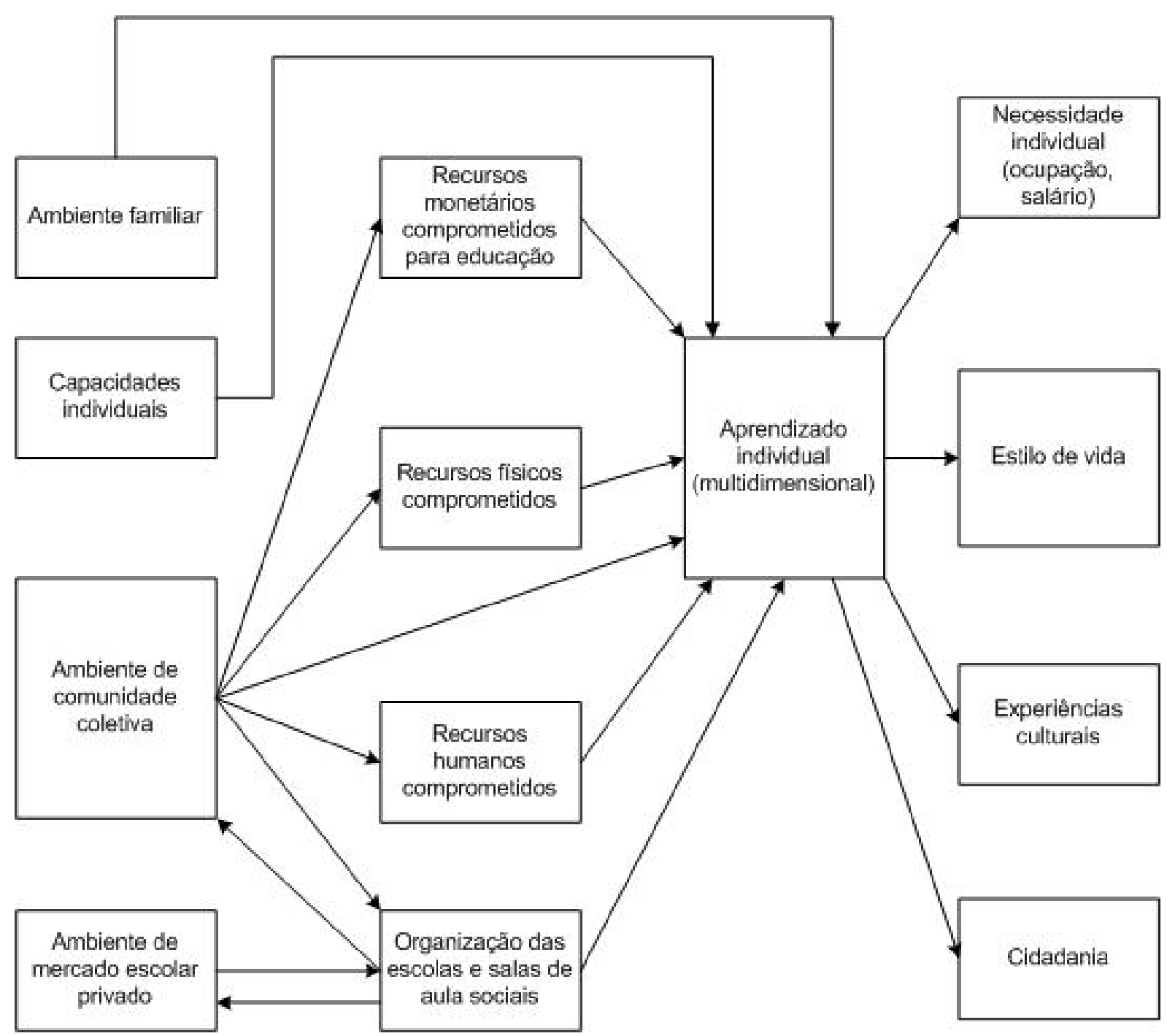

Fonte: Policy Indicator: links between social science and public debate. (MACRAE 1985, p. 132, tradução nossa).

A primeira delas diz respeito aos insumos, representados pelas variáveis: "ambiente familiar", "capacidades individuais", "comunidade" e "mercado de trabalho", todas essas variáveis incidindo diretamente no aluno ou indiretamente nele, através da escola. Na parte central do modelo, estão descritas as variáveis classicamente associadas a uma escola.

A segunda inovação relaciona-se à forma de descrever a efetividade da ação educativa no aluno, que se dá pela escolha das variáveis "preparação para o trabalho", "cidadania", "estilo de vida" e "vida cultural". Nesse caso, o aprendizado é uma variável dependente em relação às variáveis demográficas do aluno e as 
relativas ao ambiente escolar, e também uma variável explicativa desse aprendizado na inserção social futura do aluno.

Os destaques supramencionados são tratados sob a forma de indicadores nas pesquisas referentes à escola ou sistema educativo consolidadas mundialmente, em especial, a pesquisa conduzida pela OCDE, objeto de Relatório Anual denominado "Education at Glance". Por sua vez, as pesquisas de egressos também modelam seus instrumentos de coleta de dados intencionando captar os aspectos apresentados por MacRae (1985, p. 132), ou seja, a "ambiência" que influencia o aluno e a escola, e a superação da visão meramente tecnicista quando da mensuração dos resultados do aprendizado, utilizando uma abordagem tridimensional: cultura, cidadania e formação para o trabalho.

\subsection{MODELAGEM DE EQUAÇÕES ESTRUTURAIS}

De acordo com Pereira (2004) apud Corrar (2007, p.3),

a análise multivariada é um vasto campo do conhecimento que envolve uma grande multiplicidade de conceitos estatísticos e matemáticos, que dificilmente pode ser perfeitamente dominada por pesquisadores de outros campos do conhecimento, já que isso os afastaria de seu mister principal. Como tampouco pode 0 pesquisador utilizar uma estratégia metodológica desconhecendo seus princípios sob pena de má utilização, uma situação intermediária deve ser buscada, na qual possa o pesquisador ter algum conhecimento essencial que o habilite ao uso produtivo da tecnologia disponível por meio de pacotes estatísticos para computadores.

Diante disso, este estudo cuja centralidade situa-se, predominantemente, na área de conhecimento da educação almeja nesta seção - ainda que de forma sucinta - apresentar a técnica de Modelagem de Equações Estruturais objetivando, assim, embasar teoricamente a utilização deste ferramental, em softwares 
estatísticos, de forma produtiva e confiável.

A Modelagem de Equações Estruturais (Structural Equation Modeling SEM) é uma técnica estatística robusta, que a partir de um modelo onde as relações entre múltiplos construtos dependentes e independentes estão simultaneamente traçadas, permite aos pesquisadores responderem a uma série de perguntas interrelacionadas de uma forma simples, sistemática e abrangente (GEFEN, STRAUB, \& BOUDREAU, 2000).

A SEM caracteriza-se por dois componentes básicos: o modelo estrutural e o modelo de mensuração. No modelo estrutural estão relacionadas as variáveis dependentes e independentes. É nele que se sumarizam as relações causais entre as variáveis latentes. Por sua vez, o modelo de mensuração especifica os indicadores de cada variável latente e permite avaliar a confiabilidade de cada construto ao estimar as relações causais que nele ocorrem (GEFFEN ET AL., 2000; HERSHBERGER ET AL., 2003).

Com o propósito de garantir que ambos os modelos estrutural e de mensuração estejam especificados de forma correta e que os resultados sejam válidos, Schumacker e Lomax (2004) sugerem cinco os passos fundamentais: (1) especificação do modelo, (2) identificação do modelo, (3) estimação do modelo, (4) testagem do modelo e (5) modificação do modelo.

A representação pictórica das relações entre as variáveis latentes e observadas num modelo SEM apresenta as seguintes características:

- SETAS: indicam o tipo de relação entre as variáveis latentes e observadas. Se a seta for unidirecional ela indicará uma relação recursiva entre as variáveis. Se a seta for bidirecional, ela indicará uma relação não recursiva entre as variáveis, ou seja, elas têm uma relação mútua e recíproca. Cada construto no par estabelece uma relação com outro construto.

- Linha curvada bidirecional: traçadas entre duas variáveis latentes representa a correlação e a covariância destas variáveis no modelo (GARVER \& MENTZER, 1999; HAIR JR ET AL., 2005; HERSHBERGER ET AL., 2003). 
- Elipses/círculos: representam as variáveis latentes.

- Quadrados/retângulos: representam as variáveis observadas.

Para o desenvolvimento do modelo a ser testado, deve o pesquisador apoiar-se na teoria, bem como nas suas próprias experiências distinguindo quais variáveis independentes prevêem cada variável dependente (HAIR JR. ET AL., 2005; HERSHBERGER ET AL., 2003; KLEM, 2006).

Esta é, segundo Ringdon (2009), a principal aplicação da utilização da SEM: a determinação da validez de dado modelo teórico, perante os dados reais observados.

\section{SOBRE O OBJETO EMPÍRICO}

\subsection{DAS ESCOLAS DE APRENDIZES E ARTÍFICES AOS INSTITUTOS FEDERAIS: CONTEXTO HISTÓRICO E EVOLUÇÃO DA POLÍTICA PÚBLICA}

Em seu processo de constituição histórica, a Rede Federal de Educação Profissional e Tecnológica - RFEPT vivenciou marcos legais distintos, destacandose seu ato constitutivo - marco zero - o Decreto ํㅡ 7.566, de 23 de setembro de 1909, assinado pelo então presidente Nilo Peçanha que criou um conjunto de escolas de aprendizes artífices (BRASIL, 1909).

Acompanhando as normativas legais, a Rede Federal empregou diferentes denominações para nominar suas Instituições e não por acaso, a cada nova denominação, novos objetivos e desafios delineavam-se. Assim, de instituições criadas em resposta a necessidade de prover, às classes proletárias, meios que garantissem sua sobrevivência, ipsis litteris os "desprovidos da sorte e fortuna" expressão contida no seu Decreto instituidor, até a atualidade, onde são descritas em seu marco legal como "instituições de educação superior, básica e profissional, pluricurriculares e multicampi, especializados na oferta de educação profissional e 
tecnológica" (BRASIL, 2008), marca a evolução histórica desta Rede, uma profusão de alterações e reformas educativas.

(...) tanto do ponto de vista quantitativo, pela expansão das instituições e da oferta, quanto do ponto de vista qualitativo, pela nova institucionalidade, diversidade de programas e modalidades ofertadas, apresenta elementos de continuidades e descontinuidades com a concepção histórica de constituição de modelos de educação profissional e tecnológica específicos, demandando a realização de estudos e pesquisas que tratem da investigação das reformas e políticas educacionais da educação profissional e tecnológica, da natureza e objetivos de suas instituições (LIMA FILHO, 2009, p.143).

Ainda com relação ao mesmo período, Lima Filho (2009, p.148) conclui que os objetivos e a identidade das instituições de educação profissional e tecnológica pública federal foram fortemente atingidos pelas políticas neoliberais (...) e medidas conexas (...) que tinham como meta a privatização e o "empresariamento" da rede federal.

Por sua vez, Cunha (2005, p.210) traz a memória um projeto oriundo do Ministério da Educação que apesar de transformado na Lei № 8.948, de 08 de dezembro de 1994, último mês do governo Itamar Franco, segundo o autor, "simplesmente não pegou". Tal Lei instituía o Sistema Nacional de Educação Tecnológica, previa seus objetivos e metas, a sua composição e determinava também que a totalidade das escolas agrotécnicas e técnicas que seriam alçadas a condição de CEFET, além disso, criava, inclusive, um conselho superior distinto do então denominado Conselho Federal de Educação. O autor afirma que esta lei caiu em descrédito - as escolas não abraçaram a ideia - e, nos anos seguintes, "foi atropelada pela política educacional do governo seguinte que revogou quase a totalidade de seus artigos".

Este acontecimento do início dos anos 90 ilustra, de forma contundente, as fragilidades na proposição de uma política meramente pela via legal e os impactos causados por sua descontinuidade motivada pela troca de governos. Mecanismos de avaliação relacionados à implantação de políticas públicas assumem em conjunturas como essas uma grande importância no planejamento de 
novas políticas e ampliam as possibilidades de tomadas de decisões racionais.

Posteriormente, já nos dias atuais, alguns autores, da área da educação, questionam a política de migração "em bloco" para o modelo de Institutos Federais, principalmente, comparando-a com a política anterior de implantação da primeira e única Universidade Tecnológica Federal brasileira, a partir da transformação do então CEFET Paraná.

Ciavatta (2009, p. 165) chama atenção para o simbolismo do fato de que os dois CEFET mais antigos do País - CEFET Rio de Janeiro e CEFET Minas Gerais - optaram pela não adesão ao modelo dos Institutos Federais, escolhendo permanecer como CEFET, na expectativa de, no futuro, conseguir o credenciamento como Universidade Tecnológica. Além disso, a autora ainda externa uma desconfiança - de outra natureza - quanto à expansão da rede federal, revelando, ainda, que a instituição do modelo dos Institutos Federais suscita discussões sob diversos aspectos, inclusive, no que se refere à destinação de recursos públicos, verbis:

(...) surpreende-nos a expansão do sistema público de universidades federais por meio da transformação dos CEFETS em institutos, nos moldes das universidades tecnológicas. Observa-se que, há mais de uma década, as universidades públicas plenas ${ }^{3}$ lutam para sobreviver à carência de recursos para despesas elementares de manutenção, etc (CIAVATTA, 2009, p.168).

Ainda sobre a criação dos Institutos Federais, Lima Filho (2009, p.149) destaca que os efeitos produzidos por tal política demandam tempo e, sobretudo, decisões de ordem educacional, governamental e legislativa, entretanto, ressalta que importa em sua implementação as disputas e enfrentamentos entre grupos de poder com concepções e projetos distintos que ocorrem no interior das próprias instituições educacionais.

(...) é no âmago e no tempo histórico desses embates que se localizam as discussões acerca da identidade e do futuro das

\footnotetext{
${ }^{3}$ Ressalte-se que é comum - na literatura específica - recorrer à adjetivação na tentativa de diferenciar a tipologia de universidade: "universidade plena" e "universidade tecnológica".
} 
instituições de educação profissional, quer se mantenham como escolas técnicas, agrotécnicas, ou centros de educação profissional, quer venham a ser transformadas em institutos de educação, ciência e tecnologia ou em universidades tecnológicas (LIMA FILHO, 2009, p.149).

Neste entendimento, a formulação de políticas públicas assume importância substantiva, principalmente, quando a prática usual aponta para soluções pontuais, ou mesmo, programas assistencialistas que embora necessários em contextos de desigualdade e injustiça social, não podem substituir a formulação, planejamento, implantação e avaliação das políticas públicas.

\subsection{PERFIS DOS DESTINATÁRIOS DA RFEPT: DOS "DESPROVIDOS DA SORTE E FORTUNA" AOS CIDADÃOS- TRAB ALHADORES}

A profusão de alterações e reformas na Rede Federal de Educação Profissional e Tecnológica impôs impactos nas características do seu público destinatário, com alterações históricas significativas nas regiões, localidades e comunidades abrangidas pelas influências geográfica, social e econômica de suas unidades.

Esta seção aborda o processo histórico de institucionalização da educação profissional na RFETP e as mudanças no perfil de seus destinatários, segundo a ótica de quatro gestões presidenciais (Nilo Peçanha, Getúlio Vargas, Fernando Henrique Cardoso e Lula). Aqui, portanto, a categoria de análise é o público-alvo a que se destina a educação profissional. Pretende-se, assim, enfatizar a evolução histórica deste público atendido nessa rede.

Na primeira república, percebe-se o caráter fortemente assistencialista das instituições da RFEPT ao destinar a educação profissional aos "órfãos, desvalidos e desfavorecidos da fortuna" BRASIL (1909). Segundo Kunze (2009, p.12) aos olhos do dirigente do país, "os ex-escravos, mendigos, negros, loucos, 
prostitutas, rebeldes, desempregados, órfãos e viciados, que se avolumavam com o crescimento das cidades, precisavam ser atendidos, educados e profissionalizados para se transformarem em obreiros, em operariado útil, incapaz de se rebelar contra a Pátria" e o lócus para esta formação seria as escolas de aprendizes e artífices criadas por Nilo Peçanha.

Além desse fator, na implantação da República, a educação profissional foi vista como uma estratégia de consolidação e de prosperidade da nova forma de governo. Nunes (2000) apud Kunze (2009, p.12) aponta que a República precisava ser vista como a virtude homogeneizadora das diferenças, desta maneira possibilitaria igualdade política entre os cidadãos e chances de inserção na classe proletária ou no funcionalismo público, até mesmo aos de origem modesta. Assim,

[...] com o conhecimento exato das circunstâncias e das necessidades reais do País, com o aperfeiçoamento da educação popular e política das classes e dos partidos, com as expansões que forem tendo as nossas riquezas, as nossas indústrias, os retoques e as reformas indispensáveis à sua consolidação. Até ontem, a nossa missão era fundar a república; hoje o nosso supremo dever perante a pátria e o mundo é conservá-la e engrandecê-la (KUNZE, 2009, p.10).

Então, para além da criação de seus símbolos, hino, bandeira, brasão, festas comemorativas, a República precisava encaminhar solução para a rápida urbanização, para a imigração, para a modernização e a industrialização incipientes e encontrou na educação para o trabalho um caminho, muitas vezes referido com fervor patriótico percebido nos discursos da época.

Após três séculos de escravidão, a sociedade brasileira ainda ressentia as marcas profundas e os preconceitos relacionados à categoria social inferior de quem executava trabalho manual.

A herança colonial escravista influenciou preconceituosamente as relações sociais e a visão da sociedade sobre a educação e a formação profissional. O desenvolvimento intelectual, proporcionado pela educação escolar acadêmica, era visto como desnecessário para a maior parcela da população e para a formação de "mão-deobra". Não se reconhecia vínculo entre educação escolar e trabalho, pois a atividade econômica predominante não requeria educação formal ou profissional (BRASIL, 1999). 
Cunha (2005, p.6) acrescenta que o ensino artesanal e manufatureiro destinado aos miseráveis, órfãos e abandonados os preparava para ocupações socialmente definidas como próprias de escravos "e se essa exclusividade não existia, a suposição de que os escravos exerciam tais ocupações já era sinal de que elas deveriam ser evitadas pelos homens livres, para marcarem sua distinção da condição escrava".

Entretanto, a despeito do preconceito que acompanhava as ocupações mais simples, o surgimento das cidades e dos seus respectivos serviços de infraestrutura demandava por trabalhadores qualificados. Tal necessidade já era percebida mesmo antes da proclamação da República. Em 1889, D. Pedro II quando de sua Fala do Trono na última sessão da Assembleia Legislativa do Império, obteve da Câmara dos Deputados a seguinte resposta, após apresentar proposta de criação de escolas técnicas: "Não merecerão menos, senhor, a atenção da Câmara dos Deputados às exigências da instrução pública, entre as quais sobressaem, como Vossa Majestade adverte, a da criação de escolas técnicas adaptadas às conveniências locais [...]" (apud BRASIL, 1906).

Portanto, possibilitar a aprendizagem de um ofício à população das cidades em formação, representava prover incentivos ao trabalho e mão-de-obra para as indústrias que começavam a surgir no país, devido ao início do deslocamento da base econômica agrária - ainda que de forma tímida - para a industrial. Datam desta época, trechos de mensagens presidenciais que demonstram a preocupação com o progresso e modernização brasileira requerente de mão-de-obra qualificada. Em 1906: "A criação e multiplicação de institutos de ensino técnico e profissional muito podem contribuir também para o progresso das indústrias, proporcionando-lhes mestres e operários instruídos e hábeis" (apud INEP, 1987). E em 1907, "devemos cuidar com especial atenção do ensino profissional e técnico, tão necessário ao progresso da lavoura, do comércio, indústrias e artes" (apud INEP, 1987).

O signatário da norma legal de maior impacto deste período foi Nilo Peçanha. Mulato, filho de um padeiro e de uma camponesa, nascido em Campos dos Goytacazes, no Rio de Janeiro, formou-se em Direito em Recife e chegou à Presidência da República após a morte do presidente Affonso Penna. 
Na presidência deu continuidade à sua experiência como presidente do Estado do Rio de Janeiro, onde havia criado quatro escolas profissionais: Campos, Petrópolis, Niterói e Paraíba do Sul, sendo as três primeiras, para o ensino de ofícios e a última à aprendizagem agrícola. Assim, movido por experiência própria ou, complementarmente, pelos pleitos por modernização e profissionalização, em 23 de setembro de 1909, o Presidente da República Nilo Peçanha expediu o Decreto oo. 7.566 criando, em capitais do país, Escolas de Aprendizes e Artífices, fato inicial deflagrador da atual Rede Federal de Educação Profissional e Tecnológica. A justificativa mais comumente presente nos documentos oficiais para a criação das escolas técnicas, pode ser ricamente ilustrada com o trecho a seguir

[...] que o aumento constante da população das cidades exige que se facilite às classes proletárias os meios de vencer as dificuldades sempre crescentes da luta pela existência; que para isso se torna necessário não só habilitar os filhos dos desfavorecidos da fortuna com o indispensável preparo técnico e intelectual, como fazê-los adquirir hábitos de trabalho profícuo, que os afastará da ociosidade ignorante, escola do vício e do crime; que é um dos primeiros deveres do Governo da República formar cidadãos úteis à Nação [...] (INEP, 1987).

Além do flagrante caráter assistencialista, o texto que acompanhou o Decreto de criação das escolas determinava, conforme a educação recebida, a clientela a ser atendida. É preciso considerar também que, com o aumento da população nas cidades, ocorreu proporcionalmente "o medo do contágio, tanto na perspectiva de doenças físicas, da 'rudeza' de certos hábitos e valores, quanto dos próprios movimentos insurrecionais" (KUNZE, 2009, p.12) condições estas que se constituiriam num estorvo ao progresso e à almejada civilidade brasileira.

A norma legal apresentada "inaugurava o dualismo em textos legais e reservava para as elites brasileiras, o trabalho intelectual - o planejamento dos rumos do país - devendo ser formados por outro ciclo de ensino composto pelo curso de primeiras letras, secundário e superior" (BRASIL, 1998).

Assim, a educação profissional no início da República foi entendida como o agente motor no processo de transformação "daquela gente" em cidadãos 
republicanos úteis e produtivos - fora da vadiagem - e, portanto, não propícios à proliferação de ideias contrárias ao novo regime ordem social, e em adição, constituintes de uma força de trabalho que impulsionaria o progresso nacional.

Coube às Escolas de Aprendizes e Artífices - as instituições que inauguraram a atualmente conhecida RFEPT - a difusão dos valores requeridos pelo mundo do trabalho: disciplina, hierarquia, higiene, habilidades de um ofício, transformando-os em "operários frutíferos à nação, trabalhadores ordeiros $e$ qualificados para atuarem nas futuras indústrias brasileiras" KUNZE (2009, p. 10).

O segundo período presidencialista destacado, a era Vargas, apresenta uma significativa transição do enfoque do público encaminhado à educação profissional: trata-se do nascimento da classe de trabalhadores industriais assalariados, num momento histórico de rápida industrialização brasileira.

Convém destacar que o caráter da educação profissional assume neste período, sua face mais marcante, a de preparação de mão-de-obra, diminuindo a ênfase assistencialista aos órfãos e desvalidos do período anterior, embora ainda mais comumente destinada às classes menos favorecidas. Destaca-se neste período a reforma Capanema que estruturou a educação profissional de nível médio, além da criação do SENAI, instituição de caráter híbrido: custeada por contribuições compulsórias e gerida pela iniciativa privada.

Em 1930, após o que muitos autores denominam como período de intensa efervescência política, assume como chefe de um Governo Revolucionário Provisório, o gaúcho Getúlio Dorneles Vargas. Oriundo da cidade de São Borja, Rio Grande do Sul, Getúlio era formado em Direito pela Faculdade Livre de Direito de Porto Alegre e havia sido deputado estadual, deputado federal e governador do Rio Grande do Sul.

Em 1932, Fernando de Azevedo e outras 23 personalidades do meio educacional, jornalístico e cultural endereçam à nação, um documento intitulado "Manifesto dos Pioneiros da Educação Nova", publicado na imprensa em março daquele ano. A eloqüente frase inicial deste manifesto dá o tom do documento: "Na hierarquia dos problemas nacionais, nenhum sobreleva em importância e gravidade o da educação" (AZEVEDO et al, 2010, p.33). 
Os signatários do manifesto entendiam que seria impossível "desenvolver as forças econômicas ou de produção, sem o preparo intensivo das forças culturais e o desenvolvimento das aptidões à invenção e à iniciativa que são os fatores fundamentais do acréscimo de riqueza de uma sociedade" (AZEVEDO et al, 2010, p.34-35). O Brasil vivia, à época, o início de seu processo de industrialização, impulsionado pela crise mundial decorrente da quebra da bolsa de New York, e consequente crise do café. Iniciava-se o período conhecido, posteriormente, como o de substituição das importações, a título de exemplo, na era Vargas foram criadas diversas empresas estatais, dentre elas: Companhia Vale do Rio Doce, Companhia Siderúrgica Nacional, Companhia Hidrelétrica do Vale do São Francisco e Petrobras.

Lemme (2005, p.174), em seu texto "Esboço de um programa educacional extraído do Manifesto", descreve dez tópicos relevantes à conjuntura da época. Para os fins deste estudo, interessa-nos, especialmente, os abaixo transcritos:

3 - Desenvolvimento da educação técnico-profissional de nível secundário e superior, como base da economia nacional, com a necessária variedade de tipos de escolas: a) de agricultura, de minas e de pesca (extração de matérias-primas); b) industriais e profissionais (elaboradores de matérias primas); c) de transportes e comércio (distribuição de produtos elaborados); e segundo métodos e diretrizes que possam formar técnicos e operários capazes em todos os graus da hierarquia industrial.

4 - Organização de medidas e instituições de psicotécnica e orientação profissional para o estudo prático do problema da orientação e seleção profissional e adaptação científica do trabalho às aptidões naturais (LEMME, 1984).

De fato, pode-se atribuir ao texto de Lemme (1984, p.174) um caráter premonitório, visto que alguns anos após, houve uma disseminação dos exames psicotécnicos - utilizados no acesso aos cursos profissionais - além da posterior criação de escolas vocacionadas na base industrial, agropecuária e de comércio.

Entretanto, neste período um conjunto de leis, conhecidas como "Reforma Capanema", irão marcar definitivamente e por muitos anos após a estrutura do ensino secundário. Trata-se das Leis Orgânicas da Educação Nacional: a do Ensino Industrial (Decreto-Lei n.4.073, de 30/01/1942), a do Ensino Secundário (Decreto-lei n.4.244, de 09/04/42), a do Ensino Comercial (Decreto-lei n.6.141, de 28/12/1943), a 
do Ensino Normal (Decreto-lei n.8.530, de 02/01/1946) e a do Ensino Agrícola (Decreto-lei n.9.613, de 20/06/1946).

Segundo Saviani (2008, p.269), além da organicidade conferida pelo conjunto de normativas legais, sobressai-se seu caráter dualista, "separando o ensino secundário, destinado às elites condutoras, do ensino profissional, destinado ao povo conduzido e concedendo apenas ao ramo secundário a prerrogativa de acesso a qualquer carreira de nível superior". Este autor, ainda destaca o caráter corporativista da reforma, "ao vincular estreitamente cada ramo ou tipo de ensino às profissões e aos ofícios requeridos pela organização social".

Cunha (2005, p.40) por sua vez, conclui que a "articulação do ensino industrial com os demais graus e ramos se dava de modo a facilitar as entradas e a dificultar as saídas”. Desta forma, a pretensão do concluinte de um curso técnico industrial de cursar uma faculdade era desestimulada pela exigência de vinculação entre a especialidade técnica adquirida e a pretendida no curso superior.

Freitag (2005, p.140), destaca por sua vez que, somente a partir do fim do Estado Novo e com a entrada das massas no cenário político, tornou-se possível a quebra dessa estrutura dual. Na perspectiva da autora, essa unificação, entretanto, só se concretizaria no início dos anos 60, com "a flexibilização e equiparação legal entre os diferentes ramos do ensino profissional, e entre este e o ensino secundário, para fins de ingresso nos cursos superiores, embora, na prática, continuassem a existir dois tipos de ensino com públicos diferenciados".

Quanto ao público, o artigo 129 da Carta Magna, mantém a tendência histórica de destinação da educação profissional aos pobres e desfavorecidos, conquanto anuncie a ampliação da cobertura desse segmento educacional: "O ensino pré-vocacional e profissional destinado às classes menos favorecidas é, em matéria de educação, o primeiro dever do Estado. Cumpre-Ihe dar execução a esse dever, fundando institutos de ensino profissional e subsidiando os de iniciativa dos Estados, dos Municípios e dos indivíduos ou associações particulares e profissionais" (BRASIL, 1937).

No período seguinte focalizado neste estudo, governo Fernando Henrique Cardoso (FHC), destacam-se alterações quanto ao público da educação profissional 
da RFEPT, visto que àquela época era tido como moderno a formação de um novo tipo de trabalhador requerido pelos novos processos de produção e desenvolvimento tecnológico, moldado para a empregabilidade.

Dentre os presidentes citados neste estudo, Fernando Henrique Cardoso é o único com uma forte vida acadêmica ao lado de sua carreira política. Carioca, FHC, como é conhecido popularmente, é um sociólogo e cientista político brasileiro, foi professor Emérito da Universidade de São Paulo, tendo lecionado também no exterior, notadamente na Universidade de Paris. Na sua carreira política foi Senador da República, Ministro das Relações Exteriores, Ministro da Fazenda e Presidente do Brasil por duas vezes, no período de 1995 a 2002.

O discurso comum no final da era FHC era a necessidade de formação de um novo tipo de trabalhador, moldado para a empregabilidade, o que exigia mudanças nos papéis sociais da educação e, consequentemente, uma "verdadeira parceria" entre o setor privado e governo, tanto na gestão quanto no financiamento do sistema brasileiro de desenvolvimento científico e tecnológico" (LIMA FILHO, 2009, p.148). A RFEPT foi objeto de financiamento para a modernização de seus cursos, de modo que pudessem responder ao chamamento de formar trabalhadores para a empregabilidade, vinculando as ofertas às demandas, além do estímulo às parcerias com o setor produtivo.

Esse período foi marcado por uma reforma da educação profissional a partir do Acordo de financiamento com o Banco Interamericano de Desenvolvimento - BID. Com relação às características dos cursos que seriam implantados, percebese, conforme Lima Filho (2009, p.148), o fomento a "cursos pós-secundários não universitários, cursos livres de nível básico, objetivando apoiar a criação de um sistema eficaz de educação profissional para adestrar jovens e adultos”.

Reporta-se a esse período FHC também a proibição da criação de novas unidades de ensino na rede federal, que ocorreu por meio da Lei n. 9.649/98. Esta lei insere-se no suporte jurídico do governo do presidente Fernando Henrique Cardoso conferido, principalmente, pelo Decreto n. 2.208/97 (BRASIL, 1997). Salienta-se que o Decreto n. 2.208/97 atendia ao preconizado pelo Banco Mundial BID: a separação entre o ensino médio e a Educação Profissional, que a partir de 
então passaram a percorrer trajetórias separadas e não equivalentes. Desta forma, retornava a dicotomia do ensino nos moldes da exigência do mercado de trabalho: 0 Ensino Médio Propedêutico (que prepara o aluno para o ingresso no Ensino Superior) e o agora então chamado Ensino Profissionalizante (que prepara os jovens para o mercado de trabalho). "Nesta forma de análise quem dita as regras e o que é necessário para a formação dos jovens trabalhadores são os empresários, e não mais os pedagogos, educadores. Aparecem competências até então não valorizadas, onde além do Português e da Matemática, uma nova disciplina surge: a capacidade de trabalhar em grupo e de se adaptar a novas situações" (CASTRO, 2001 apud FRIGOTTO, CIAVATTA, 2003).

Nas palavras do Secretário Nacional de Educação Profissional e Tecnológica - daquele período - Ruy Berger; "O Brasil optou por romper com um modelo que preconizava a solução conciliatória entre os objetivos de preparar para o prosseguimento de estudos e a formação para o trabalho num ensino de segundo grau profissionalizante. A educação profissional foi definida como complementar a uma vertente ao mesmo tempo terminal e propedêutica" (BERGER FILHO, 1999, p.8).

Por fim, esse período, além de restringir o crescimento da RFEPT, é marcado pela alteração do perfil dos destinatários da educação profissional: jovens para o trabalho assalariado, com perfil de manter-se empregável no setor produtivo em reestruturação e reconversão econômica, configurado por mudanças tecnológicas aceleradas, instabilidade na oferta de empregos e alta competitividade mercadológica.

O quarto período presidencial focalizado, o governo Lula, acrescenta às demandas da educação profissional os alunos na faixa etária de 14 a 17 anos inseridos, devido a ênfase conferida ao ensino médio integrado ofertado pela RFEPT.

No governo Lula, uma das políticas de maior visibilidade, referente à Educação Profissional foi a expansão da Rede Federal de Educação Profissional e Tecnológica. Para dimensionar o impacto desta expansão, deve-se ressaltar que no período de 1909 a 2002, o Brasil teve 24 presidentes e construiu no total 140 
escolas técnicas federais. No período de 2003 a 2010, apenas durante a gestão de um único presidente foram construídas e inauguradas 214 novas unidades federais, o que representa um crescimento na ordem de $150 \%$ a maioria destas escolas situadas no interior do País. O Gráfico 4 ilustra esse crescimento acelerado a partir de 2008.

Gráfico 4-Distribuição de Matrículas por níveis na Rede Federal de Educação Profissional e Tecnológica

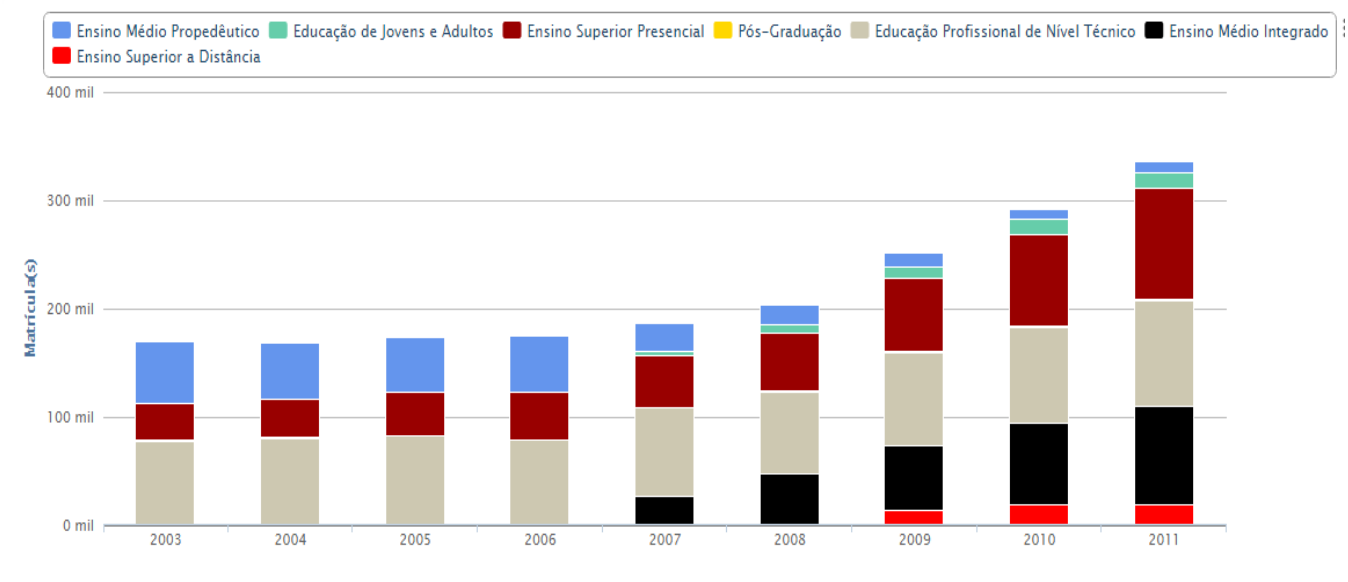

Fonte: SIMEC/MEC

É importante salientar ainda que a expansão e interiorização da Rede Federal de Educação Profissional e Tecnológica tem o potencial de contribuir para o processo de democratização do ensino e de desenvolvimento local. "A interiorização dos Institutos Federais está viabilizando que populações rurais, antes apartadas do acesso a um ensino público de qualidade, passem a ter contato com outra realidade educacional. Isto seguramente proporcionará a este contingente populacional um outro referencial de educação pública" (ARRUDA, 2010, p.3).

Finalmente, convém apontar o papel estratégico que desempenham a educação e a produção do conhecimento científico-tecnológico na construção de uma sociedade mais justa "a razão fundamental para que a política de educação profissional e tecnológica, seja de Estado, fundada na justiça social a partir da participação de todos na produção, na fruição do que foi produzido, na cultura e no poder, o que demanda processos educativos que articulem formação humana e sociedade na perspectiva da autonomia crítica, ética e estética". (KUENZER, 2006, 
p. 150).

Com esta expansão vultosa, ampliam-se as possibilidades de acolher e formar o novo trabalhador: o cidadão produtivo. A política orientadora desse período, para as instituições da RFEPT, supera a formação assistencialista dos primórdios da embrionária Rede, voltada para os desvalidos da sorte e os menos afortunados, para passar a formar o cidadão trabalhador, gestor de sua força de trabalho num mundo cada vez mais competitivo e globalizado, incluindo jovens de todas as camadas sociais, sobretudo dos núcleos urbanos e rurais mais distanciados dos eixos tradicionais de desenvolvimento no país.

\section{PROCEDIMENTOS METODOLÓGICOS}


Segundo Kerlinger (1980, p. 18), o propósito básico da ciência é chegar à teoria, inventar e descobrir explicações válidas de fenômenos naturais, destacando que na produção de conhecimento científico são o método e a técnica que caracterizam o trabalho ou o estudo como científico ou não. Assim, a descrição da metodologia a ser utilizada na pesquisa científica assume um papel central para o seu desenvolvimento, em observância ao método e ao rigor científico, na busca das evidências empíricas para as hipóteses elencadas, garantindo, inclusive, condições de replicação.

Barbeta (2007, p.23) afirma que nas pesquisas cientificas é necessário coletar dados com o objetivo de fornecer informações capazes de responder as indagações do pesquisador. Mas, para que os resultados da pesquisa sejam confiáveis, tanto a coleta dos dados quanto a sua análise deve ser feita de forma criteriosa e objetiva. Ainda segundo Barbeta (idem, p.24) não é possível obter boas informações de dados que foram coletados de forma inadequada. A qualidade da informação depende da qualidade dos dados. Do mesmo modo, para que a análise dos resultados seja feita de forma correta o pesquisador deve conhecer os princípios básicos das técnicas utilizadas no tratamento dos dados.

Este capítulo irá apresentar a metodologia utilizada na condução da pesquisa, os seus procedimentos, os métodos, as técnicas e os instrumentos para coleta, tratamento, e análise dos dados.

\section{Estrutura Metodológica}

O desenho do processo metodológico, ilustrado na Figura 10, apresenta sua estrutura, expondo as atividades e fluxo de operação executados na elaboração, coleta e análise das diversas bases de dados utilizadas na pesquisa.

Figura 10-Fluxograma do processo metodológico 


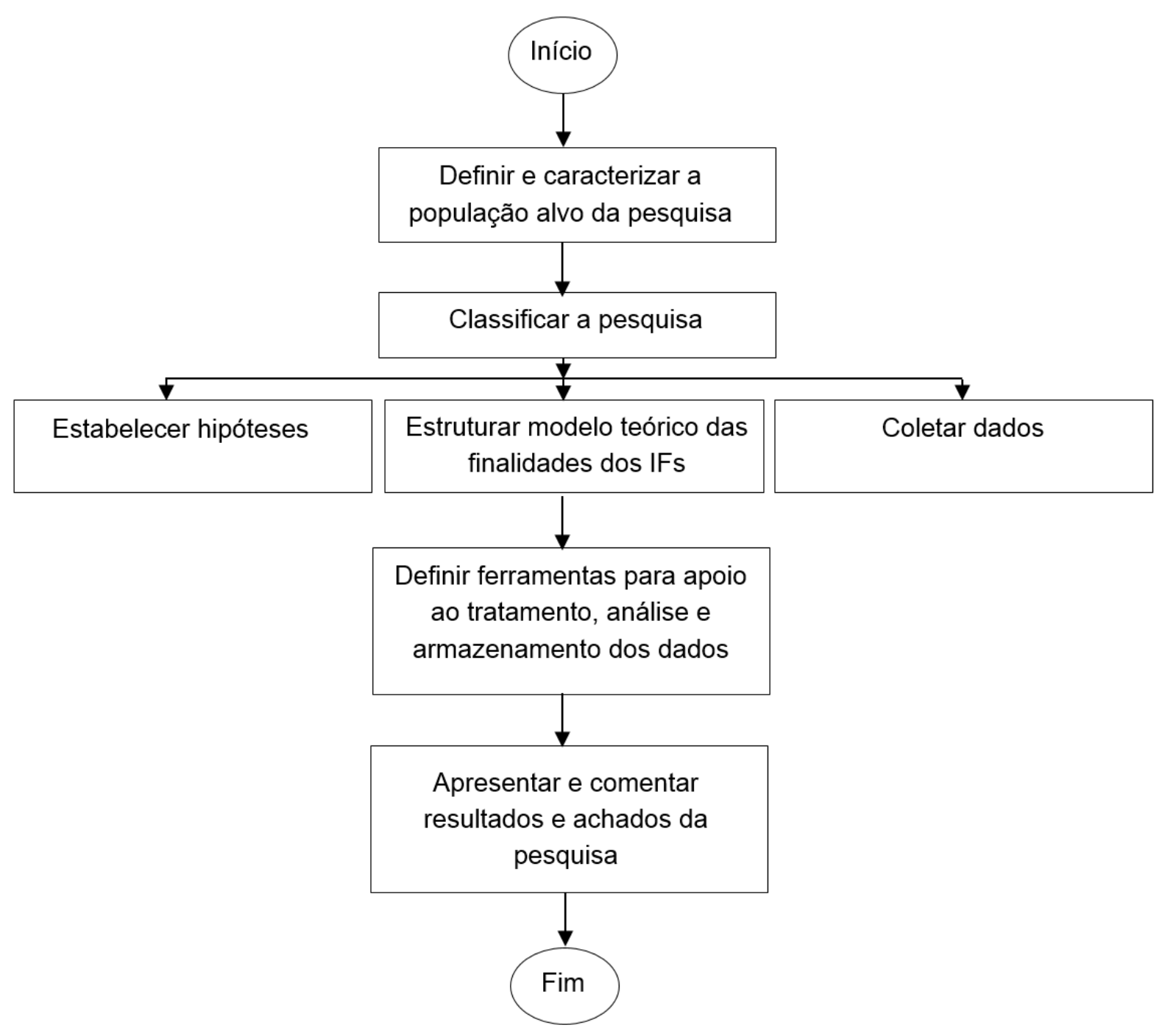

Fonte: Elaboração da autora

\section{Caracterização da População alvo da pesquisa}

Os estudos relacionados com essa pesquisa direcionam-se aos trinta e oito Institutos Federais de Educação, Ciência e Tecnologia - IFs, com recorte temporal dos dados referente ao ano de 2013. Ressalte-se que isso representa toda a população do objeto em estudo. Os Institutos são autarquias criados por lei e estão presentes em todos os estados da federação.

\section{Classificação da pesquisa}


De acordo com Moresi (2003, p. 11-14), esta pesquisa é classificada quanto à natureza como aplicada, quanto à abordagem do problema como quantitativa e qualitativa. Quanto aos fins como conclusiva descritiva.

É considerada uma pesquisa aplicada porque gera conhecimentos para aplicação prática dirigido à solução de problemas específicos. Do ponto de vista da forma de abordagem do problema é considerada como quantitativa. Para Minayo (2003), a pesquisa quantitativa traduz em números as opiniões e informações a serem classificadas e analisadas, utilizando-se de técnicas estatísticas. Constitui-se em uma pesquisa descritiva, pois expõe características de determinada população: os Institutos Federais, observando, analisando, classificando e interpretando fatos e dados, sem interferência do pesquisador.

Gil (1994, p.45) afirma que as pesquisas descritivas têm como objetivos "descrever características de determinada população ou fenômeno ou o estabelecimento de relações entre as variáveis". Malhotra (2006) acrescenta que o objetivo principal da pesquisa descritiva é descrever características ou funções de mercado, podendo ser usada para descrever características de grupos relevantes, tais como consumidores, vendedores, organizações ou mercados, e para determinar o grau em que variáveis de marketing estão associadas. Como método para a coleta de dados para a pesquisa descritiva, o autor cita a coleta de dados secundários, realização de surveys, a observação e outros dados. Para Malhotra (2006) o objetivo principal da pesquisa conclusiva é testar hipóteses específicas e examinar relações. Como principais características deste tipo de pesquisa, citam-se as seguintes: as informações necessárias estão claramente definidas; o processo de pesquisa é formal e estruturado; o plano amostral normalmente é largo e representativo; e análise de dados dá-se de forma quantitativa. Os resultados têm natureza conclusiva e normalmente são utilizados como inputs em processos decisórios. 


\section{HIPÓTESES}

A hipótese de pesquisa objetiva ampliar o conhecimento científico para além das fronteiras atuais do conhecimento teórico. Conexão entre especulação e teste, a hipótese de pesquisa é fator de crescimento do conhecimento científico.

Alguns atributos são essenciais à formulação adequada de hipótese de pesquisa, segundo Silva (2010, p.43) dentre eles:

- a hipótese tem que ter significado e ser formalmente correta;

- deve basear-se em conhecimento prévio;

- deve ser relacionada logicamente com a teoria na qual está amparada;

- deve prover uma resposta ao problema específico que a inspirou;

- deve ser tão específica e simples quanto possível; e

- deve ser verificável empiricamente, isto é, deve possibilitar o seu teste.

Importa ressaltar que o teste de uma hipótese em busca de corroborar ou refutar seu enunciado é, sempre, expressa em termos relativos, nunca em termos absolutos, segundo o grau de confirmação estabelecido.

Deste modo, estabelece-se um dilema, quando do delineamento da pesquisa, envolvendo de um lado a complexidade das hipóteses e de outro, a necessidade de coleta e teste de evidências empíricas. Fundamentalmente, deve-se evitar que a metodologia conduza à omissão de conhecimento tácito e/ou teórico sobre o mundo real, sobre o problema de pesquisa. Sob pena de que tal formulação não venha acrescentar à nossa compreensão sobre o passado nem nos possibilitar predições úteis sobre a viabilidade de opções de política pública.

A tradição neopositivista atribui muita importância ao teste de hipóteses, mas não à sua formulação original. Mesmo autores que abordam a questão da elaboração de hipóteses causais o fazem estabelecendo regras formais relacionadas a critérios de falibilidade, consistência interna, concretude e grau de generalização. Mas, a "substância das hipóteses deveria de alguma forma emergir da criatividade não-adestrada ou da intuição do indivíduo pesquisador em vez de submeter-se exatamente à mesma disciplina profissional que é corretamente exigida para o teste de hipóteses". (SCHARPF, 1997:27-8) 
Diante, da impossibilidade da elaboração de teorias completas passíveis de testes empíricos, pode-se recorrer a formulação de modelos que construídos a partir de hipóteses possam responder, "por que e como uma dada configuração de condições gera o efeito em questão" e que possa coletar evidência empírica de que o efeito previsto está sendo produzido.

As hipóteses deste estudo estão a seguir listadas. Ressalte-se que o número de hipóteses elaboradas é superior às hipóteses que serão submetidas ao teste, ou aquelas que estarão presentes no modelo teórico, isso justifica-se pela importância de registro de inter-relações identificadas pela observação do objeto em estudo ou advindas da teoria e que poderão ser testadas por pesquisas subsequentes.

H1: A titulação dos professores influencia na ampliação da oferta de cursos superiores.

H2: A titulação do corpo docente e infraestrutura laboratorial incidem positivamente na qualidade dos cursos de graduação ofertados.

H3: O crescimento da oferta de cursos superiores inibe o crescimento da oferta de cursos técnicos.

H4: O contexto produtivo local exerce impacto positivo na produção científica.

H5: A maior especialização do Instituto influencia o aumento na produção científica.

H6: O contexto educativo influencia positivamente a quantidade e diversidade de cursos ofertados.

H7: A titulação do corpo docente e a qualidade da infraestrutura laboratorial impactam positivamente na produção científica.

H8: A diversidade da oferta de cursos influencia na inserção laboral dos egressos.

H9: O contexto Produtivo associado a infraestrutura de laboratórios e equipamentos do instituto implicam em maior empregabilidade.

H10: A ampliação da oferta de cursos FIC incide no aumento da verticalização. 
H11: A diversidade e qualidade da oferta de cursos influenciam na percepção de confiabilidade da Instituição pela comunidade.

H12: A aderência às demandas do setor produtivo influencia a inserção laboral dos egressos.

H13: A origem do Instituto, quanto as Instituições que o compuseram, influencia a redução na especialização de sua oferta.

H14: A atuação em todos os níveis e modalidades da EPT impacta positivamente na verticalização e na percepção de confiabilidade da Instituição.

H15: A atualização curricular influencia positivamente na percepção de qualidade do curso pelo aluno.

H16: O quantitativo de campi influencia diretamente o desempenho da gestão e implica na redução da qualidade de seus cursos.

H17: O contexto educativo e cultural associado à infraestrutura de equipamentos culturais do instituto implicam em maior quantitativo de ações culturais.

H18: A titulação do corpo docente implica em maior registro de propriedade intelectual e patentes.

H19: A quantidade e diversidade de licenciaturas ofertadas influencia na elevação dos índices de qualidade do sistema de ensino. 


\title{
6. RESULTADOS
}

Esse capítulo apresenta os resultados desse trabalho construídos a partir de observações, dados e referenciais teóricos.

\subsection{APLICAÇÃo de UMA TIPOLOGIA de REDE dE POLÍtICAS PÚBLICAS AO CASO DO CONSELHO NACIONAL DE INSTITUIÇÕES DA REDE FEDERAL DE EDUCAÇÃO PROFISSIONAL E TECNOLÓGICA - CONIF: A REDE DENTRO DA REDE}

\begin{abstract}
A voga que a palavra e a ideia de rede estão encontrando, tanto nas ciências exatas e sociais, como na vida prática, paga o preço devido a essa popularidade. Sua polissemia tudo invade, afrouxa o seu sentido e, pode, por isso, prestarse a imprecisões e ambiguidades (SANTOS, 2002, p. 261-2).
\end{abstract}

$\mathrm{Na}$ vida contemporânea, assim como no debate teórico, acentua-se a importância do conceito de rede, em suas diferentes dimensões. Conforme Musso (2004, p.17), "hoje, a noção de rede é onipresente, e mesmo onipotente em todas as disciplinas". Daí a tendência - nos estudos que adotam a rede como conceito-chave - de sua adjetivação e da formulação de tipologias, como um recurso de qualificação, que parece cumprir a tarefa de delimitação do seu emprego a fenômenos particulares. Desse modo, constata-se a proliferação de uma grande variedade de conceitos de redes desdobrados: rede urbana, redes técnicas, redes territoriais, redes políticas, etc.

Dada a atualidade de uma sociedade da informação, não surpreende que pesquisadores de matizes e disciplinas diferentes, passem a utilizar progressivamente o termo de redes, explorando suas potencialidades e a capacidade de resposta que oferece para diferentes problemas, em diferentes 
domínios. A pluralidade de formulações utilizadas para se pensar o conceito de rede não invalida o seu uso, contudo, impõe a necessidade de reflexão acerca das diversas acepções relativas ao termo.

O conceito de rede ganhou relevância significativa no âmbito das políticas públicas, tanto como fenômeno empírico e estratégia político-administrativa quanto como conceito teórico e analítico.

Destaca-se, inicialmente, os processos de democratização e descentralização administrativa, fortalecendo os poderes locais, os arranjos de governança, mas também a dinamização dos processos computacionais devido ao uso crescente das tecnologias de informação e comunicação em todos os setores sociais e governamentais, convergindo para à horizontalização das relações organizacionais, inaugurando outras práticas de interação e de colaboração. Governar torna-se um processo interativo porque nenhum ator detém sozinho o conhecimento e a capacidade de recursos para resolver problemas unilateralmente. Ademais, a concepção da rede configurou-se como categoria de análise para os processos político-administrativos e decisórios nas sociedades contemporâneas. Nesta perspectiva, trata-se basicamente de saber em que medida as abordagens estruturais podem contribuir para explicar não apenas os processos político administrativos (politics), mas também os resultados ou conteúdos da política (policy) (GOLDSMITH e EGGERS, 2004).

Nas ciências sociais, a análise das redes tem sido sempre um campo, por excelência, de interdisciplinaridade. Inicialmente, usado em sentido metafórico, não se identificavam características morfológicas, uteis para a descrição de situações específicas nem estabeleciam relações entre as redes e o comportamento dos indivíduos que as constituem. Recentemente, o estudo de redes sociais e políticas constituiu-se como com domínio especifico do conhecimento e tem se institucionalizado de forma progressiva, demonstrando sinais evidentes de dinamismo.

Mesmo recebendo críticas pela suposta falta de rigor teórico e força explanatória, a abordagem parece ganhar notoriedade à medida que contribui a demonstrar as limitações das teorias tradicionais, consolidadas e com um aparente maior vigor e consistência teórico, 
mas com limitações para explicar a nova complexidade da vida social contemporânea. Neste sentido, adeptos da abordagem da rede como Kenis e Schneider (1991, p.25) atribuem ao conceito de rede a qualidade de se tornar o novo paradigma para a 'arquitetura da complexidade', mesmo admitindo que ainda não poderia ser considerada uma "teoria explícita", talvez antes "um método na busca de uma teoria". A análise de redes não é uma teoria in stricto sensu, mas antes um kit ferramental para descrever e medir configurações relacionais e suas características estruturais. A abordagem revela um potencial significativo de contribuir para o aprimoramento das teorias sociais dominantes, de evidenciar seus limites explicativos, além de, no âmbito das ciências políticas, possibilitar uma investigação de diferentes dimensões dos processos e políticas públicas que frequentemente escapam dos métodos tradicionais da análise de

políticas públicas e, portanto, são negligenciadas pelas teorias tradicionais (KENIS, SCHNEIDER, 1991, p25, p.41).

\subsection{REDES DE POLÍTICAS PÚBLICAS}

Entende-se por redes Políticas as interações das diferentes instituições e grupos tanto do executivo, do legislativo como da sociedade na gênese e na implementação de uma determinada política. Segundo Bonafont (2004. p. 379) tratase de redes de relações sociais que se repetem periodicamente, porém menos formais e delineadas do que relações sociais institucionalizadas, nas quais é prevista uma distribuição concreta de papeis organizacionais. Todavia, essas redes sociais evidenciam-se suficientemente regulares, para que possa surgir confiança entre seus integrantes e se estabelecer opiniões e valores comuns. Redes políticas são vistas "como um conjunto de relações relativamente estáveis, de natureza nãohierárquica e independente, que vincula uma variedade de atores que compartilham interesses comuns em referência a uma política, e que fazem intercâmbio de recursos para perseguir esses interesses compartilhados, admitindo que a cooperação é a melhor maneira de alcançar as metas comuns" (BONAFONT, 2004. p. 84).

As redes de políticas sociais são um instrumento fundamental para a gerência das políticas sociais em contextos democráticos, permitindo a construção de novas formas de coletivização, socialização, organização solidária e coordenação 
social. Nesse sentido, as redes transcendem o papel de um mero instrumento gerencial, na medida em que permitem gerar relações baseadas na confiança (capital social) e processos gerenciais horizontalizados e pluralistas (esfera pública democrática).

Assim, no âmbito desta tese, o estudo da Rede de Educação Profissional e Tecnológica requer, igualmente, o entendimento de sua rede política de governança. Neste sentido, não é apenas uma exigência ontológica, mas representa uma adequação importante do ferramental analítico à complexidade dos Institutos Federais de Educação, Ciência e Tecnologia.

Sendo a escola, ou especificamente, os Institutos Federais, uma organização social, pode-se explicá-la como:

um agrupamento humano formado por interações entre pessoas com cargos diferentes, especialidades distintas e histórias de vida singulares que, entretanto, compartilham objetivos comuns e decidem, de forma pública, participativa e solidária, os processos e os meios de conquista desses objetivos. Existem, assim, objetivos e processos de decisão compartilhados, mas não há ausência de direção; ao contrário, admite-se a conveniência de canalizar atividade das pessoas para objetivos e executar as decisões, considerando, de um lado, a necessidade de realizar com eficácia as tarefas, de cumprir os objetivos, de obter resultados, de fazer a organização funcionar e de realizar avaliações; e, de outro, a necessidade de coordenar o trabalho das pessoas, de assegurar um ótimo clima de trabalho, de enfrentar e superar os conflitos, de propiciar a participação de todos nas decisões, em discussão aberta e pública dos fatos, com confiança e respeito aos outros (LIBÂNEO; OLIVEIRA; TOSCHI, 2003, p.382-383).

Bonafont (2004, p.91) vai além ao afirmar que o marco legal e institucional importa, porém são os agentes, os indivíduos, que os interpretam e tomam suas decisões considerando restrições e oportunidades e de acordo com sua visão do problema.

Desse modo, a participação do corpo social da escola no processo de implantação e elaboração de seu projeto político depende não apenas da vontade de seus membros para mobilizar-se e defender seus interesses em torno a problemas concretos, mas também da estrutura da organização, o grau de 
profissionalização, a dependência de seus membros com respeito as funções que realiza. No plano federativo, importa o grau de reconhecimento pela autoridade governamental como ator legítimo para representar os interesses de um coletivo e participar na política. Um setor bastante mobilizado caracteriza-se pelo monopólio de representação do sector por somente uma organização que representa a maioria do sector. Essa associação se organiza a nível político técnico e ou territorial com o fim de gerar informações, levar a cabo funções específicas e manter a coesão interna em torno de uma só associação. (BONAFONT, 2004. p. 66 e 67).

O processo de elaboração de políticas públicas não se define unicamente pelas características estruturais da rede, mas também pela forma como cada um dos atores interpreta esta estrutura. Marsh e Smith (2000 apud BONAFONT, 2004, p. 91) desenvolveram um modelo dialético de análise de rede, objetivando abordar questões e proporcionar um marco teórico mais completo para explicar o processo de implantação de políticas públicas, considerando três tipos de relações:

- a rede e os atores que dela participam;

- a rede e o contexto onde se desenvolve a ação; e

- a rede e o resultado político.

As considerações de Bonafont (2004, p.91) e de Marsh e Smith (2000 apud BONAFONT, 2004, p.91) no âmbito de uma tipologia dos Institutos Federais merecem destaque tendo em vista a prática e a tradição destas unidades escolares de atuarem em Rede. E tal prática precede a concepção e o marco legal da criação do Institutos Federais no Brasil que cunhou o termo Rede, constituindo-se assim relevante pilar desta nova institucionalidade. Uma vez que a simples previsão em marco legal não impediria um distanciamento entre aquilo que se propõe no nível do discurso político e a realidade social concreta da vida organizacional dos Institutos Federais, a menos que não fosse, a sua prática anterior de realidade colaborativa em diversas dimensões, sejam elas geográficas, temáticas ou decorrentes de relações interpessoais do corpo social. 


\subsubsection{O CONSELHO NACIONAL DE INSTITUIÇÕES DA REDE FEDERAL DE EDUCAÇÃO PROFISSIONAL E TECNOLÓGICA - CONIF}

O Conselho Nacional das Instituições da Rede Federal de Educação Profissional, Científica e Tecnológica (CONIF) congrega todas as Instituições Federais de Educação Profissional, Científica e Tecnológica do Brasil. É uma instância de discussão, proposição e promoção de políticas de desenvolvimento da formação profissional e tecnológica, pesquisa e inovação.

Dentre suas atividades, desenvolve atividades de promoção de estudos e projetos, de natureza interdisciplinar e interinstitucional, por meio de eventos como congressos e encontros; incentiva o intercâmbio de informações e experiências entre as instituições que compõem o Conselho e também com instituições de ensino, pesquisa e extensão, entidades culturais, científicas e tecnológicas nacionais e estrangeiras; executa articulações com os diversos entes públicos e a sociedade civil organizada nas esferas federal, estadual e municipal.

Este conselho criado em março de 2009, após a publicação da Lei $n^{\circ}$ 11.892/2008, que instituiu a Rede Federal de Educação Profissional e Tecnológica e criou os Institutos Federais de Educação, Ciência e Tecnologia, representou a fusão e transformação dos conselhos anteriormente constituídos, a saber: Conselho de Dirigentes dos Centros Federais de Educação Tecnológica - CONCEFET, Conselho de Diretores das Escolas Técnicas Federais - CONDITEC e o Conselho de Escolas Agrotécnicas Federais - CONEAF.

São objetivos do Conselho Nacional das Instituições da Rede Federal de Educação Profissional, Científica e Tecnológica, previstos em seu regimento:

I - Fomentar a integração, o fortalecimento e a consolidação das instituições federais de educação profissional, científica e tecnológica, bem como sua valorização e defesa;

II - Promover ações para a definição de políticas que assegurem o caráter público, gratuito e inclusivo das Instituições que compõem esse Conselho; 
III - Promover ações visando o desenvolvimento da Educação Profissional, Científica e Tecnológica de acordo com as finalidades, características e objetivos constantes na Lei 11.892/2008.

IV - A representação do conjunto de suas filiadas, inclusive judicialmente, exercida na forma deste Estatuto.

Importa frisar que as atividades relativas a estudos setoriais são de responsabilidade das câmaras e fóruns constituídos no âmbito desse conselho, com periodicidade de reuniões ainda mais frequente e densidade temática expressiva, dentre eles, em especial: o fórum dos pró-reitores de ensino, de extensão, pesquisa e gestão de pessoas. Bem como as câmaras temáticas de desenvolvimento institucional, campo e relações internacionais.

Entender a organização dos subgrupos pode ser importante para entender o comportamento da rede como um todo. Por exemplo, as informações tendem a fluir mais rápida e consistentemente em subgrupos coesos. Usualmente, as redes complexas são compostas de inúmeras estruturas mais simples, o que permite uma análise posicional, procedimentos que analisam as similaridades estruturais de grupos de atores e a padrões de relacionamentos e a identificação de classes de equivalência, denominadas "blocos" ou posições, onde cada posição contém atores que se relacionam de modo semelhante na rede.

Estas redes parciais, seriam "qualquer extração de uma rede total, com base em algum critério que seja aplicável à rede total". Recorrendo a metáfora de uma constelação: os indivíduos que estivessem, em relação direta na rede principal, seriam estrelas de primeira grandeza, enquanto aqueles que não fossem diretamente ligados, mas aqueles que estivessem ligados a um agente diretamente a ela relacionado, poderiam ser acionados para um contato através de sua intermediação, ou seja, estrelas de segunda grandeza. Uma rede seria, portanto, uma construção social de relações de grandezas distintas, mas que possibilitariam o contato entre os diversos elementos que iriam gerar sua composição. A título de exemplificação, da ordem de grandeza numérica do CONIF e seus fóruns, em sua última reunião de dirigentes, ocorrida em Novembro de 2014, na cidade de Porto 
Alegre, o CONIF, congregou cerca de 700 reitores, pró-reitores e diretores das unidades que compõem a rede federal. Este conjunto de dirigentes configura-se como redes de pessoas, conectam-se ou vinculam pessoas, ainda que essa pessoa seja o diretor da instituição e se relacione com seu cargo incluído; mas não se conectam cargos entre si, não se conectam instituições entre si, não se conectam computadores entre si, conectam-se pessoas.

Outro aspecto que merece destaque, relaciona-se a forma de escolha dos dirigentes da Rede Federal.

Desde 2009, o Decreto № 6.986, de 20 de outubro de 2009, disciplina o processo de escolha de dirigentes no âmbito destes Institutos, definindo a eleição para os cargos de Reitor e de Diretor-Geral de campus pela comunidade escolar, com mandatos de quatro anos. Todos os servidores que compõem o Quadro de Pessoal Ativo Permanente da Instituição, bem como os alunos regularmente matriculados nos cursos de ensino médio, técnico, de graduação e de pósgraduação, presenciais ou a distância, participam do processo de consulta e não há a existência de lista tríplice a ser enviada ao Ministério da Educação. O processo de consulta será finalizado com a escolha de um único candidato para cada cargo, considerando-se o peso da participação de cada segmento representado. Posteriormente, o Reitor e o Diretor-Geral de campus designarão seus substitutos na forma do disposto nos regimentos internos. As consultas para o cargo de DiretorGeral nos campi deverão ser realizadas após cinco anos de seu efetivo funcionamento.

Diante deste quadro, destaca-se o papel do CONIF no processo de implementação e apoio as políticas, na forma em que se discutem e analisam os problemas, na criação de rotinas e agendas de comportamento e no estabelecimento de imperativos organizacionais, e eventualmente, no apoio ou oposição as políticas definidas nacionalmente. Marsh e Smith (2000 apud BONAFONT, 2004, p.92) destacam esse modelo de redes políticas a partir três pressupostos:

Os interesses e as preferências dos membros na rede não se definem unicamente nos termos de sua participação. As restrições e oportunidades atribuídas pelo marco institucional não se produzem 
de forma automática, dependem da interpretação que realiza cada um dos atores envolvidos. Os membros da rede têm formação e conhecimentos específicos que influenciam na sua capacidade de aproveitar oportunidades e negociar restrições impostas pelo marco institucional. As estruturas normativas têm um papel importante na definição dos objetivos e estratégias a seguir na política, em curso, mas, isso não significa que não exista espaço para uma outra opção de interpretação e conduta (MARSH e SMITH, 2000, p.6 apud BONAFONT, 2004, p.92).

\subsubsection{PROPOSTA DE TIPOLOGIA DE REDE POLÍTICA}

A primeira contribuição desse trabalho é a elaboração de uma proposta de tipologia de rede política passível de aplicação a qualquer rede de escolas, Todavia, ressalta-se que a referida tipologia é fruto de um processo representacional e classificatório e como todo processo desta natureza é um produto de uma construção que representa o estado e visão do conhecimento desta autora, especificamente relativo a escolas de educação profissional e tecnológica e baseada em revisão de literatura, especialmente as tipologias de Rhodes e Marsh, Van Waarden e Atkinson . (BONAFONT, 2004. p. 79 - 87). Ressalte-se que, ainda no corpo desta tese, no capítulo seguinte, outra tipologia, denominada Atlas da Rede Federal de Educação Tecnológica será apresentada. Por isso convém explicitar os princípios pelos quais tais representações foram construídas, sob óticas distintas. A presente tipologia - Tabela 1, caracteriza-se pelo foco nas informações relacionais de um conjunto de atores - os dirigentes da Rede Federal, em seus parâmetros relacionais que caracterizam redes sociais. Devido ao foco no relacionamento, esta tipologia não confunde-se com a seguinte, na qual, outros atributos e categorias de análise serão representadas.

Através da primeira abordagem, ao se analisar as conexões diretas e indiretas da rede, pode-se olhar para as propriedades relacionadas à sua estrutura $e$ conectividade, na tentativa de obter tendências sociais decorrentes desta estrutura, ou ainda identificação de subestruturas importantes desta rede. Diversas propriedades podem ser obtidas e analisadas considerando-se a estrutura e conectividade da rede. Em geral são propriedades simples, mas que fornecem 
informações relevantes para auxiliar na compreensão da população observada. Exemplos de medidas que avaliam a estrutura básica da rede e sua conectividade são tamanho, compatibilidade, recursos, dentre outros.

- Tamanho da rede: propriedade, aparentemente, simples, todavia, muito importante. O tamanho da população é uma das variáveis críticas na análise sociológica, como também no âmbito das ciências políticas. Podemos nos imaginar que no âmbito das políticas públicas, a gestão de um conjunto pequeno de escolas seria menos extenuante do que a coordenação do que um conjunto de 562 unidades exigindo colaboração de um grande número atores. O tamanho da rede é dado pelo número de atores e de relações.

- Ingresso, continuidade de participantes e o tipo de união: propriedades que descreve o mecanismo de entrada, com suas eventuais barreiras ou limites de entrada a participantes novos; o grau esperado de manutenção dos mesmos atores como participante da rede, bem como o grau de ordem na posterior participação em rede.

- Conectividade: a conectividade da rede pode ser avaliada a partir das relações das quais cada ator participa. O número de relações de que o ator participa na rede é o seu grau de conectividade. As medidas de conectividade ajudam a explicar certos comportamentos ou processos decorrentes da conectividade social, como solidariedade, densidade moral e complexidade da organização social.

- Compatibilidade dos membros: corresponde aos níveis de congruência de valores e de concordância sobre os objetivos. Nesse aspecto, o desafio está em conciliar o objetivo da rede com os objetivos particulares dos membros.

- Ambiente de mobilização de recursos: que corresponde à disponibilidade de fundos e o tipo de controle sobre esses recursos.

- Ambiente social e político: que corresponde às bases de poder e ao padrão de conflitos. Considera-se o conflito como uma consequência inevitável na relação de interdependência e deve ser aproveitado em 
seus aspectos construtivos, como o "ajustamento" de poder e de recursos entre as organizações.

- Legitimidade e monopólio: reconhecimento, por parte dos agentes públicos, de sua interlocução e representação das necessidades de um coletivo. Existem uma ou várias organizações com acesso a arena política? E se o Estado escuta a todos os grupos igualmente, ou a alguns, escuta com maior intensidade? Esta característica representa a posição estrutural do grupo no processo de elaboração de políticas públicas.

- Estabilidade: a formação de redes tem sido frequentemente caracterizada como uma resposta à incerteza e instabilidade que caracteriza o ambiente organizacional. O ambiente incerto é gerado por recursos escassos e pela falta de um perfeito conhecimento das flutuações ambientais. A incerteza induz às organizações a estabelecer e gerenciar inter-relações na busca de uma maior estabilidade e previsibilidade do ambiente.

- Finalidade: a finalidade de uma rede expressa a sua razão de ser nas dimensões política, religiosa, filosófica, científica, econômica, cultural e social. A finalidade dá o significado aos objetos que são trocados na rede e se encontra por vezes incorporada aos indivíduos que participam da rede, orienta as escolhas da dimensão ética dentro do qual uma rede evolui e inspira seus projetos.

- Reciprocidade: a formação das relações está baseada na reciprocidade. Os eventuais motivos de reciprocidade enfatizam a cooperação, colaboração e a coordenação entre organizações, ao invés de dominação, poder e controle. Nessa perspectiva, as redes políticas ocorrem para o propósito de buscar interesses e objetivos comuns.

- Eficiência: a rede reduz a dispersão de esforços e permite um ganho de produtividade e eficiência. Reduz também o tempo de busca de novos objetos uma vez que a interconexão entre indivíduos significa agilidade no compartilhamento de objetos de interesses mútuos. 
- Fluidez: significa a capacidade de flexibilidade e adaptabilidade das redes às novas dimensões do ambiente. Essa propriedade fundamental permite três tipos de inter-relações:

- Espacial: a rede permite colocar em relação subconjuntos ou unidades geograficamente dispersas;

- Temporal: a rede assegura a permanência das ligações entre indivíduos que participam da rede; e

- Social: a rede permite homogeneizar as relações de comunicação por parte dos atores sociais que possuem condições sociais diferentes, sem implicar na mudança dessa condição.

- Tipo de participação: entendida como a capacidade dos participantes de participar da decisão e gestão de um problema concreto. A rede caracteriza-se como horizontal ou hierarquizada? É usual a divisão e diferenciação em subgrupos ou redes específicas?

- Orientação política e autonomia: entendida como a postura política na definição dos objetivos e estratégicas em torno a problemas comuns à rede e o nível existente de autonomia.

Tabela 1-Tipologia de redes de políticas públicas

\begin{tabular}{|c|c|c|}
\hline Dimensão & & \\
\hline Tamanho da rede & Reduzido & Amplo \\
\hline $\begin{array}{l}\text { Ingresso (limites ou } \\
\text { barreiras de entrada a } \\
\text { participantes novos) }\end{array}$ & Apenas Dirigentes & $\begin{array}{l}\text { Aberto conforme demandas } \\
\text { e interesses }\end{array}$ \\
\hline Tipo de união & Caótico & Ordenado \\
\hline $\begin{array}{ll}\text { Continuidade de } \\
\text { participantes }\end{array}$ & Elevada & Variável \\
\hline Conectividade & Elevada & Reduzida ou ocasional \\
\hline $\begin{array}{l}\text { Ambiente de mobilização } \\
\text { de recursos }\end{array}$ & $\begin{array}{l}\text { Todos os participantes têm } \\
\text { recursos que intercambiam em } \\
\text { um plano de igualdade ou a }\end{array}$ & $\begin{array}{lcr}\text { Recursos } & \text { limitados } \mathrm{e} \\
\text { distribuídos } & \text { de forma } \\
\text { desigual } & & \end{array}$ \\
\hline
\end{tabular}




\begin{tabular}{|c|c|c|c|c|}
\hline & \multicolumn{2}{|c|}{ partir de um pacto } & & \\
\hline $\begin{array}{l}\text { Ambiente social e político: } \\
\text { consenso ou conflito }\end{array}$ & \multicolumn{2}{|c|}{$\begin{array}{lr}\text { Consenso } & \text { Elevado. Os } \\
\text { participantes } & \text { compartilham } \\
\text { valores básicos } & \end{array}$} & $\begin{array}{l}\text { Existe um } \\
\text { porém o } \\
\text { presente }\end{array}$ & $\begin{array}{l}\text { certo acordo } \\
\text { conflito está }\end{array}$ \\
\hline $\begin{array}{l}\text { Ambiente social e político: } \\
\text { tipo de interesse }\end{array}$ & \multicolumn{2}{|c|}{ Político/orçamentário } & \multicolumn{2}{|c|}{$\begin{array}{l}\text { Existem muitos tipos de } \\
\text { interesses, não há a } \\
\text { predominância de nenhum }\end{array}$} \\
\hline Legitimidade & \multicolumn{2}{|l|}{ Elevada } & \multicolumn{2}{|c|}{ Reduzida ou ocasional } \\
\hline $\begin{array}{l}\text { Monopólio em relação a } \\
\text { representação do grupo }\end{array}$ & \multicolumn{2}{|l|}{ Existente } & \multicolumn{2}{|l|}{ Ausente } \\
\hline Estabilidade & \multicolumn{2}{|l|}{ Incipiente } & \multicolumn{2}{|l|}{ Conquistada } \\
\hline Finalidades & \multicolumn{2}{|c|}{$\begin{array}{l}\text { Predominam em negociações a } \\
\text { defesa de interesse particular }\end{array}$} & \multicolumn{2}{|c|}{$\begin{array}{ll}\text { Predominam } & \text { em } \\
\text { negociações a defesa de } \\
\text { interesse geral }\end{array}$} \\
\hline Reciprocidade & \multicolumn{2}{|l|}{ Ocasional } & \multicolumn{2}{|c|}{$\begin{array}{l}\text { Constante histórica } \mathrm{e} \\
\text { crescente }\end{array}$} \\
\hline Eficiência & Existente. & Incipiente & & Ausente \\
\hline Fluidez: espacial & \multicolumn{2}{|l|}{ Geográfica } & \multicolumn{2}{|l|}{ Setorial } \\
\hline Fluidez: temporal & \multicolumn{2}{|l|}{ Periódica } & \multicolumn{2}{|l|}{ Ocasional } \\
\hline Fluidez: social & \multicolumn{2}{|c|}{ Apoia a simetria de informações } & \multicolumn{2}{|c|}{ Assimetria de informações } \\
\hline $\begin{array}{l}\text { Tipo de participação: } \\
\text { regime }\end{array}$ & \multicolumn{2}{|l|}{ Voluntária } & \multicolumn{2}{|l|}{ Obrigatória } \\
\hline $\begin{array}{l}\text { Tipo de participação: } \\
\text { coordenação das tarefas } \\
\text { e projetos comuns }\end{array}$ & Hierárquica & Horizontal & Consultivo & Deliberativo \\
\hline $\begin{array}{l}\text { Tipo de participação: } \\
\text { tomada de Decisão }\end{array}$ & \multicolumn{2}{|c|}{$\begin{array}{l}\text { Aberta, proporcionando } \\
\text { informações sobreo conteúdo e } \\
\text { acordos alcançados }\end{array}$} & \multicolumn{2}{|c|}{$\begin{array}{lr}\text { Secreta. } & \text { Opacidade } \\
\text { ao quanto } \\
\text { negociações }\end{array}$} \\
\hline $\begin{array}{l}\text { Tipo de participação: } \\
\text { divisão em subgrupos ou } \\
\text { redes específicas }\end{array}$ & \multicolumn{2}{|c|}{ Frequente e esperada } & \multicolumn{2}{|l|}{ Ocasional } \\
\hline Orientação política & Muito politizada & Pragmática & & Ideológica \\
\hline Nível de autonomia & \multicolumn{2}{|l|}{ Elevada } & \multicolumn{2}{|l|}{ Reduzida } \\
\hline
\end{tabular}

Fonte: Elaboração da autora a partir de revisão bibliográfica e experiência profissional. 
A partir desse esforço conceitual, podemos fazer algumas observações a título de conclusão desta seção e transpor o conceito simbólico de rede para usá-lo analiticamente como instrumento metodológico de compreensão de relações sociais entre indivíduos do CONIF.

A aplicação da tipologia em comento ao CONIF resultaria na tipificação, a seguir apresentada.

O Conselho Nacional de Instituições da Rede Federal de Educação Profissional e Tecnológica é uma rede política de tamanho elevado, com barreiras definidas de acesso, conectividade e autonomia elevada, de caráter pragmático e goza de legitimidade e monopólio junto a entidade governamental central. Ao longo de sua existência, este conselho adquiriu estabilidade, mecanismos de reciprocidade e fluidez, tendo acompanhado, inclusive, as transformações institucionais da Rede Federal mantendo seu espaço de interlocução e poder.

Esta rede política favorece seus laços de densidade por meio de um intenso regime de participação de seus componentes e da usual estratégia de divisão em subgrupos para estudo, acompanhamento e proposição de temas específicos. Possui uma estrutura de coordenação consultiva e horizontalizada. A participação de seus membros é obrigatória e o ambiente de mobilização de recursos é definido a partir de um pacto, especificamente as contribuições à matriz de alocação de recursos MEC. Na discussão de seus temas, percebe-se um consenso elevado, não sendo muito usual, a manutenção de conflito. Por fim o ambiente social e político desta rede configura-se pela predominância de interesses políticos e orçamentários e as negociações, geralmente, finalizam com a defesa interesses de ordem geral.

\subsection{TAXONOMIA DOS INSTITUTOS FEDERAIS}


O segundo produto e contribuição desse trabalho diz respeito a uma proposta de taxonomia para os Institutos Federais, fundamentada na pesquisa bibliográfica, principalmente a da teoria de classificações de Apostel (1963) e na experiência profissional da autora.

Os termos tipologia e taxonomia são utilizados, por diversos autores, de maneira intercambiável. Entretanto, existe consenso, qualquer que seja o termo utilizado, quanto ao fato de que deve haver uma construção teórica - uma teoria das diferenças - amparado esta classificação, a simples observação empírica não atenderia a esse princípio fundamental. De forma contrária aos esquemas classificatórios, tipologias e taxonomias, requerem a existência de uma teoria subjacente.

A teoria proporciona as bases sobre as quais se desenvolve o sistema de classificação; a explicação necessária para a classificação; os temas centrais que regem a classificação; os tipos de variáveis a serem utilizados; as relações complexas entre essas variáveis; e as fronteiras entre os grupos (RICH, 1992). Em síntese, Miller (1996, p.5) considera tipologias como "conjuntos de configurações derivados conceitualmente", e taxonomias como "conjuntos de configurações derivados empiricamente" (MEYER et al., 1993, p. 1182).

Independente do caráter indutivo ou dedutivo que assumem as taxonomias, destacam-se alguns elementos comuns importantes nesse tipo de construção e que consistem:

- incluir todas as características relevantes do fenômeno estudado;

- ter aplicação geral e não específica;

- ser intemporal (e, portanto, aplicável a qualquer período de tempo, passado e futuro);

- existência de construtos (tipos ideais e dimensões usadas para descrevê-los);

- identificação das relações entre os construtos (consistência interna dos tipos ideais); e 
- falsificabilidade (a taxonomia pode ser testada empiricamente e estar sujeita a desconfirmação).

Por sua vez, as taxas (conjuntos de objetos semelhantes entre si e distintos dos demais, ou grupos derivados empiricamente) devem obedecer aos seguintes requisitos:

- ser mutuamente excludentes;

- ser internamente homogêneas (membros de uma taxon devem ser mais semelhantes entre si do que aos membros de outras taxa);

- coletivamente exaustivas (cada caso deve ser enquadrável em alguma taxon); e

- serem nomeadas de forma relevante.

As taxonomias partem das evidências empíricas para explorar similaridades e diferenças dentro de determinada população para, a partir de critérios selecionados com auxílio de um referencial teórico, buscar explicar semelhanças e diferenças nas estruturas e padrões de determinada população ou fenômeno.

A delimitação das fronteiras de uma taxonomia implica na especificação de uma determinada área ou população que ela se propõe a abarcar e, consequentemente, diferenciar em termos de determinados padrões. Nesse aspecto, um aspecto importante no esforço de classificação de Institutos Federais recai particularmente no seu caráter multidimensional. Enquanto que a maior parte das taxonomias educacionais encontradas na literatura ocupam-se de dados referente a oferta educativa, a taxonomia dos IFs implica na delimitação de fronteiras que combinam especificidades setoriais e territoriais. Assim, a inclusão do contexto territorial como parte dos limites que a tipologia de IF pretende explorar aumenta consideravelmente o grau de diversidade e heterogeneidade entre grupos.

Um problema recorrente na construção de tipologias e taxonomias refere-se à a importância do contexto a partir do qual as configurações analisadas se originam, se estruturam e se transformam. Ao ignorar a importância do contexto (em termos das 
especificidades dos agentes, do sistema de relações, dos valores e instituições subjacentes, do ambiente sócio-político-econômico e da própria história) análises freqüentemente se baseiam na suposição de que existem padrões gerais (ou benchmarks) a serem seguidos. Como reflexo, é relativamente comum que realidade seja interpretada não a partir daquilo que ela tem de específico, mas em relação à sua maior ou menor proximidade em relação a um determinado modelo de referência. (BRITO, 2011. p. 2 )

A hipótese geral que orienta o desenvolvimento desta taxonomia é de que cada Instituto Federal de Educação Ciência e Tecnologia apresenta - em função de seu processo histórico, do padrão de especialização de oferta educativa, do contexto sócio-econômico-político e da base institucional subjacente - uma configuração que Ihe é única. A utilização de taxonomia dos Institutos Federais para interpretar essa realidade é um procedimento metodológico válido, mas que não pode se converter em uma "camisa de força" analítica que delimita, a priori, as possibilidades de desenvolvimento e de reestruturação daquele território.

Ainda sobre as características gerais e requisitos necessários aos pesquisadores quando do desenvolvimento de uma taxonomia, Apostel (1963) em sua obra de referência Le Problème Formel des Classifications Empiriques aponta como fundamental o domínio da realidade, a um profundo conhecimento teórico ou tácito do objeto em estudo.

Segundo o autor, cada classificação fundamenta-se a partir de um mecanismo classificador que, em última instância determinará, melhor ou pior, as operações necessárias ao estudo classificatório.

Outro aspecto relevante da atividade classificatória, citado pelo mesmo autor, relaciona-se com a multiplicidade de fins que, em última análise vão determinar a sua estrutura.

Assim, entende-se que cada classificação constrói-se no contexto das classificações precedentes do mesmo domínio, ou seja, há uma inexorável historicidade das classificações ao longo da qual os domínios classificados podem ser modificados, as divisões podem ser completadas, novos critérios de classificação podem ser acrescentados. 
Apostel (1963) refere, ainda, que para cada classificação existe um produto externo da atividade classificadora. A classificação supõe uma dupla operação: o estabelecimento de equivalências entre classes do espaço classificatório global; o estabelecimento de hierarquias entre classes do espaço classificatório global; o estabelecimento de hierarquias entre subclasses no interior das classes estabelecidas.

Bonafont (2004, p.89), por sua vez, alerta para a atenção que deve dedicar o pesquisador no desenvolvimento de propostas classificatórias: a ambiguidade terminológica, a clareza na definição das dimensões e o dissenso na escolha das dimensões mais significativas a serem utilizadas na definição das redes.

A taxonomia proposta, nesta tese, fundamenta-se na pesquisa bibliográfica somada com a experiência profissional da autora - por meio de fontes primárias - e considera a Teoria de Classificações de Apostel (1963).

A Rede Federal de Educação Profissional, Científica e Tecnológica é composta de instituições educacionais com mais de cem anos de existência as quais se configuram por tipologias variadas o que sinaliza para elementos de complexidade e valor agregado numa rede que pode potencializar suas capacidades intrínsecas pela conexão e interparticipação entre si. Com a evolução e expansão da rede, agregaram-se perfis institucionais de diferentes origens, áreas geográficas, população atendida, ofertas educacionais, cultura organizacional, cronologia e distintos vínculos com o setor produtivo em contextos mais ou menos tecnológicos.

Segundo Pacheco e Resende (2009, p.10) a proposta dos Institutos Federais entende a educação como instrumento de transformação e de enriquecimento do conhecimento, capaz de modificar a vida social e atribuir maior sentido e alcance ao conjunto da experiência humana.

Características classificatórias podem constituir-se em variável de força que impacta nos resultados dessas instituições. Para tanto, impõe-se considerar as características que configuram cada uma dessas instituições a partir de categorias que as distinguem, independentemente da moldura legal comum que as definiu.

A lei federal 11.982/2008 que cria os Institutos Federais de Educação, Ciência e Tecnologia define suas finalidades e características, verbis: 
I - ofertar educação profissional e tecnológica, em todos os seus níveis e modalidades, formando e qualificando cidadãos com vistas na atuação profissional nos diversos setores da economia, com ênfase no desenvolvimento socioeconômico local, regional e nacional;

II - desenvolver a educação profissional e tecnológica como processo educativo e investigativo de geração e adaptação de soluções técnicas e tecnológicas às demandas sociais e peculiaridades regionais;

III - promover a integração e a verticalização da educação básica à educação profissional e educação superior, otimizando a infraestrutura física, os quadros de pessoal e os recursos de gestão; IV - orientar sua oferta formativa em benefício da consolidação e fortalecimento dos arranjos produtivos, sociais e culturais locais, identificados com base no mapeamento das potencialidades de desenvolvimento socioeconômico e cultural no âmbito de atuação do Instituto Federal;

$\mathrm{V}$ - constituir-se em centro de excelência na oferta do ensino de ciências, em geral, e de ciências aplicadas, em particular, estimulando o desenvolvimento de espírito crítico, voltado à investigação empírica;

VI - qualificar-se como centro de referência no apoio à oferta do ensino de ciências nas instituições públicas de ensino, oferecendo capacitação técnica e atualização pedagógica aos docentes das redes públicas de ensino;

VII - desenvolver programas de extensão e de divulgação científica e tecnológica;

VIII - realizar e estimular a pesquisa aplicada, a produção cultural, o empreendedorismo, o cooperativismo e o desenvolvimento científico e tecnológico;

IX - promover a produção, o desenvolvimento e a transferência de tecnologias sociais, notadamente as voltadas à preservação do meio ambiente. (BRASIL, 2008).

Tais características e finalidades, delineadas pela lei, fornecem pistas para a construção de taxonomia capaz de orientar a coleta de dados e informações desses institutos que os configurem segundo o grau de conformidade com o modelo prescrito para sua atuação.

Portanto, pode-se estabelecer uma proposta de taxonomia baseada, fundamentalmente, naqueles indicadores construídos a partir de dados secundários, sistematicamente levantados pelo IBGE e do próprio Ministério da Educação. Na proposta de taxonomia desenvolvida nesta tese são apresentados alguns indicadores que seriam desejáveis, permitindo um maior detalhamento da ação educativa dos Institutos, mas que dependeriam de um esforço de levantamento 
através de pesquisas de egressos, conduzidas com metodologia e periodicidade anual.

O foco em dados secundários de fácil acesso garante a praticidade do sistema proposto e sua fácil replicação. Enfatiza-se no sistema classificatório a articulação sistêmica para fortalecimento das capacitações produtivas e inovativas de forma sustentada e comprometimento com o desenvolvimento local.

Associado ao anterior e tendo por base a diversidade histórica dessas instituições federais e os comandos legais estabelecidos para sua atuação, propõese a seguinte taxonomia - Tabela 2, Tabela 3,

Tabela 4, para classificação e estudos que possam fornecer subsídios quanto a possíveis diferenças de resultados alcançados pelos institutos, mesmo contando com iguais aparatos de ordem legal, organizacional e financeira.

Tabela 2-Taxonomia dos Institutos Federais quanto ao porte

\begin{tabular}{|c|c|c|}
\hline \multicolumn{3}{|c|}{ Porte } \\
\hline $\begin{array}{l}\text { Associação com } \\
\text { prioridades e estratégia } \\
\text { da política nacional }\end{array}$ & $\begin{array}{l}\text { - Reduzir desigualdao } \\
\text { aumento do adensamento }\end{array}$ & $\begin{array}{l}\text { es regionais mediante } 0 \\
\text { da oferta educativa de EPT }\end{array}$ \\
\hline \multirow[t]{2}{*}{ Dimensão } & \multicolumn{2}{|c|}{ Indicadores associados } \\
\hline & $\begin{array}{l}\text { Indicadores baseados em dados } \\
\text { secundários }\end{array}$ & $\begin{array}{l}\text { Indicadores baseados em } \\
\text { dados primários }\end{array}$ \\
\hline Localização da sede & Capital ou Interior & - \\
\hline $\begin{array}{l}\text { Arranjo institucional } \\
\text { prévio }\end{array}$ & $\begin{array}{l}\text { Natureza jurídica e vinculação } \\
\text { federal anterior à lei 11.892/2008 }\end{array}$ & - \\
\hline Data de criação & Idade da Sede & \\
\hline $\begin{array}{l}\text { Abrangência } \\
\text { geográfica }\end{array}$ & $\begin{array}{l}\text { População dos municípios } \\
\text { inseridos no raio de abrangência } \\
\text { do IF }\end{array}$ & - \\
\hline
\end{tabular}




\begin{tabular}{|l|l|c|}
\hline Porte & Quantitativo de campi & - \\
\hline Raio de abrangência & $\begin{array}{l}\text { Distância entre os Campi dos } \\
\text { IFS }\end{array}$ & - \\
\hline
\end{tabular}

Fonte: elaboração da autora a partir de pesquisa bibliográfica.

Tabela 3-Taxonomia dos Institutos Federais quanto à ação educativa

\begin{tabular}{|c|c|c|}
\hline \multicolumn{3}{|c|}{ Ação Educativa } \\
\hline $\begin{array}{l}\text { Associação com } \\
\text { prioridades e estratégia } \\
\text { da política nacional }\end{array}$ & \multicolumn{2}{|c|}{$\begin{array}{l}\text { - Ampliar as modalidades, níveis e estratégias de } \\
\text { oferta da EPT } \\
\text { - } \text { Ampliar a diversidade e qualidade dos cursos de } \\
\text { EPT ofertados } \\
\text { - Ampliar a geração, assimilação e uso de } \\
\text { conhecimentos e inovações } \\
\text { - Fomentar a pesquisa e inovação }\end{array}$} \\
\hline \multirow[t]{2}{*}{ Dimensão } & \multicolumn{2}{|c|}{ Indicadores associados } \\
\hline & $\begin{array}{l}\text { Indicadores baseados em dados } \\
\text { secundários }\end{array}$ & $\begin{array}{l}\text { Indicadores baseados em } \\
\text { dados primários }\end{array}$ \\
\hline \multirow[t]{2}{*}{$\begin{array}{l}\text { Níveis de atuação na } \\
\text { educação } \\
\text { - Distribuição } \\
\text { da oferta de } \\
\text { cursos, vagas e } \\
\text { matrículas. }\end{array}$} & $\begin{array}{l}\text { - } \text { FIC } \\
\text { - } \quad \text { Técnico integrado ao } \\
\text { - médio } \\
\text { - } \quad \text { Técnico concomitante } \\
\text { Técnico subsequente } \\
\text { ao médio }\end{array}$ & - \\
\hline & $\begin{array}{cc}\text { Graus de oferta superior } \\
\text { - } & \text { Bacharelado } \\
\text { - } & \text { Tecnológico } \\
\text { - } & \text { Licenciatura } \\
\text { - } & \text { Pós-graduação }\end{array}$ & - \\
\hline $\begin{array}{l}\text { Eixos Tecnológicos de } \\
\text { atuação educacional e } \\
\text { científica } \\
\begin{array}{r}\text { - } \\
\text { Concentraçã } \\
\text { o, especialização }\end{array}\end{array}$ & $\begin{array}{l}\text { - } \text { Todos os eixos tecnológicos } \\
\text { - Apenas eixos tecnológicos } \\
\text { ligados a ciências agrárias } \\
\text { - Apenas eixos tecnológicos } \\
\text { ligados à produção industrial }\end{array}$ & - \\
\hline
\end{tabular}




\begin{tabular}{|c|c|c|}
\hline $\begin{array}{lr}\text { ou } & \text { diversidade } \\
\text { da } & \text { oferta } \\
\text { educativa } & \end{array}$ & $\begin{array}{l}\text { - Apenas eixos tecnológicos } \\
\text { ligados à gestão e comércio } \\
\text { - Apenas eixos tecnológicos } \\
\text { ligados à saúde e meio } \\
\text { ambiente } \\
\text { - Especializado (até três eixos } \\
\text { tecnológicos). }\end{array}$ & \\
\hline \multirow[t]{3}{*}{$\begin{array}{l}\text { Características dos } \\
\text { alunos }\end{array}$} & - & $\begin{array}{l}\text { Caracterização do alunado: } \\
\text { escolaridade, sexo, idade, } \\
\text { raça e renda. } \\
\text { Escolaridade dos pais } \\
\text { Migração } \\
\text { Verticalidade } \\
\text { Ações de assistência } \\
\text { estudantil }\end{array}$ \\
\hline & Quantitativo de Oferta & $\begin{array}{l}\text { Cursos com exclusividade } \\
\text { na oferta nacional }\end{array}$ \\
\hline & Empregabilidade & $\begin{array}{l}\text { Estágios } \\
\text { Inserção laboral do } \\
\text { alunado prévia e pós curso } \\
\text { de EPT } \\
\text { Continuidade de estudos }\end{array}$ \\
\hline Força de trabalho & $\begin{array}{l}\text { Distribuição por faixa etária, } \\
\text { sexo, dedicação } \\
\text { Distribuição por titulação } \\
\text { Razão entre docentes/alunos }\end{array}$ & $\begin{array}{l}\text { Sintonia do currículo com o } \\
\text { entorno sócio-produtivo } \\
\text { Experiências de inserção } \\
\text { laboral }\end{array}$ \\
\hline $\begin{array}{l}\text { Produção científica e } \\
\text { tecnológica }\end{array}$ & $\begin{array}{l}\text { Grupos de pesquisas } \\
\text { Bolsas PIBID } \\
\text { Bolsas PIBIT }\end{array}$ & $\begin{array}{l}\text { Patentes registradas } \\
\text { Alunos envolvidos com } \\
\text { pesquisas } \\
\text { Projetos em tecnologia } \\
\text { social } \\
\text { Projetos de inovação } \\
\text { tecnológica } \\
\text { Programas de extensão } \\
\text { Programas de divulgação }\end{array}$ \\
\hline
\end{tabular}




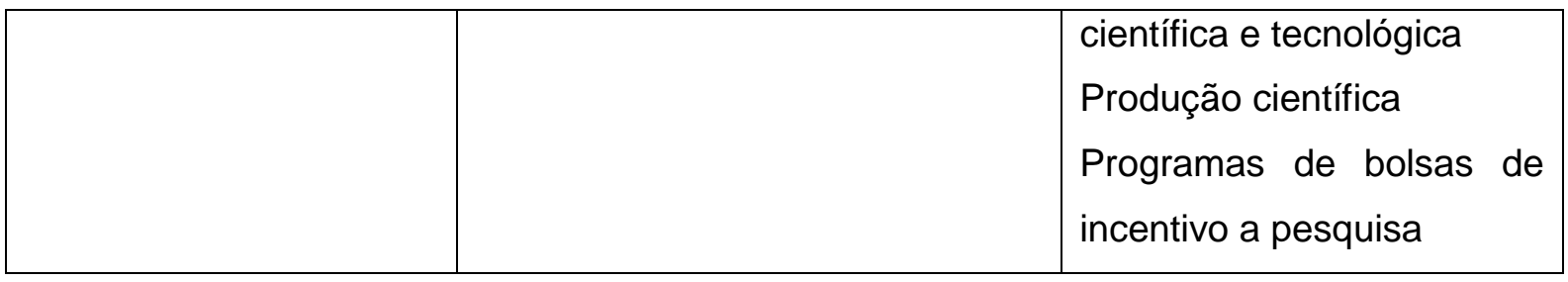

Fonte: elaboração da autora a partir dos dados do Sistec/MEC.

Tabela 4-Taxonomia dos Institutos Federais quanto ao contexto no qual se insere

\begin{tabular}{|c|c|c|}
\hline \multicolumn{3}{|c|}{ Contexto Sócio-cultural-produtivo } \\
\hline $\begin{array}{l}\text { Associação com } \\
\text { prioridades e estratégia } \\
\text { da política nacional }\end{array}$ & \multicolumn{2}{|c|}{$\begin{array}{l}\text { - } \quad \text { Apoiar a inclusão produtiva ; } \\
\text { - } \quad \text { Fomentar a redução de desigualdades regionais } \\
\text { mediante a oferta de ações educativas; } \\
\text { - } \quad \text { Apoiar e fomentar a cena cultural; } \\
\text { - } \quad \text { Apoiar o crescimento socialmente inclusivo e } \\
\text { ambientalmente sustentável. }\end{array}$} \\
\hline \multirow[t]{2}{*}{ Dimensão } & Indicadores ass & sociados \\
\hline & $\begin{array}{l}\text { Indicadores baseados em dados } \\
\text { secundários }\end{array}$ & $\begin{array}{l}\text { Indicadores baseados em } \\
\text { dados primários }\end{array}$ \\
\hline $\begin{array}{lr}\text { Características } & \text { da } \\
\text { População } & \text { alvo } \\
\text { beneficiária } & \end{array}$ & $\begin{array}{l}\text { IDEB } \\
\text { Concluintes do ensino médio/ano } \\
\text { IDH dos municípios-sede }\end{array}$ & - \\
\hline Contexto Tecnológico & $\begin{array}{l}\text { Presença de Internet por tipo, nos } \\
\text { municípios-sede } \\
\text { Presença de centros ou núcleos } \\
\text { de pesquisa nos municípios-sede } \\
\text { Presença de empresas de } \\
\text { produção tecnológica nos } \\
\text { municípios-sede } \\
\text { Recepção de TV analógica e } \\
\text { digital nos municípios-sede } \\
\text { Relação computador/população } \\
\text { nos municípios-sede } \\
\text { Relação aparelho telefonia }\end{array}$ & - \\
\hline
\end{tabular}




\begin{tabular}{|c|c|c|}
\hline & $\begin{array}{l}\text { móvel/população nos municípios- } \\
\text { sede }\end{array}$ & \\
\hline Contexto Produtivo & $\begin{array}{l}\text { Taxa de ocupação da PEA } \\
\text { Taxa de formalização do trabalho } \\
\text { № APLs nos municípios-sede } \\
\text { (arranjos produtivos, sociais e } \\
\text { culturais) } \\
\text { № Empresas de produção de } \\
\text { bens nos municípios-sede } \\
\text { № Empresas comerciais e outros } \\
\text { serviços nos municípios-sede }\end{array}$ & - \\
\hline $\begin{array}{l}\text { Contexto Educacional } \\
\text { e Cultural }\end{array}$ & $\begin{array}{l}\text { № de escolas de educação básica } \\
\text { nos municípios-sede } \\
\text { № de escolas de educação } \\
\text { profissional e tecnológica } \\
\text { № de instituições de ensino } \\
\text { superior nos municípios-sede } \\
\text { № de teatros nos municípios-sede } \\
\text { № de locais para grandes eventos } \\
\text { nos municípios-sede } \\
\text { № de casas de cultura nos } \\
\text { municípios-sede }\end{array}$ & $\begin{array}{l}\text { Movimentos culturais do IF } \\
\text { Ampliação ao acesso a } \\
\text { cultura pós-curso }\end{array}$ \\
\hline
\end{tabular}

Fonte: elaboração da autora a partir da revisão da literatura.

Finalmente, um elemento adicional que está implícito na construção de taxonomias reside na sua capacidade de captar a dinâmica de transformação e evolução, seja de setores ou de configurações educativas. A taxonomia proposta, nesta tese, pretende detalhar, através de um instrumento classificatório, o emaranhado institucional decorrente do processo histórico de constituição dos Institutos Federais, traduzindo a riqueza e diversidade deste conjunto de Instituições. 


\subsection{ATLAS DA REDE FEDERAL DE EDUCAÇÃO PROFISSIONAL E TECNOLÓGICA}

O terceiro produto desse trabalho apresenta a conjuntura e a configuração da oferta educativa dos Institutos Federais de Educação, Ciência e Tecnologia, no ano de 2013, utilizando, quando possível, as categorias de análise previstas na taxonomia proposta por esta tese. Neste sentido, seguiram-se as seguintes etapas de elaboração:

Analisar os dados da Educação Profissional sob a ótica de variáveis selecionadas que possibilitem conhecer aspectos relacionados com as categorias do corpo docente, comunidade, entorno produtivo, ofertas de cursos de graduação e de técnicos, e atividades de pesquisa nos Institutos Federais, entre outras, possibilita por um lado, conhecer o contexto na qual a Rede Federal de Educação Profissional, Científica e Tecnológica vem se expandindo e, por outro, permite fazer um diagnóstico sobre o adensamento da Rede e sua contribuição na qualificação de egressos para o trabalho.

Esta agregação de dados se traduz em mapas de identidade da rede federal revelando suas classes, agrupando num instrumento de organização intelectual o atual estágio do objeto em estudo. O produto final constitui-se em uma Atlas da Rede Federal de Educação Profissional e Tecnológica. A seguir detalhamse as categorias de análise e a respectiva distribuição dos Institutos Federais.

\subsubsection{CATEGORIA DE ANÁLISE: CONFIGURAÇÃO DE ORIGEM}

Nesta categoria importa detalhar a origem dos atuais Institutos Federais quanto a sua composição. Anterior a Lei de criação da rede federal, o cenário da Educação Profissional e Tecnológica Federal era composto por CEFET - Centro 
Federal de Educação Profissional e Tecnológica; EAF - Escola Agrotécnica Federal, ETF - Escola técnica Federal e ETUF - Escola Técnica vinculada às Universidades Federais. Com a criação a rede, estas instituições sofreram na maior parte das vezes, processos de fusão e transformação, e em outras, processos de separação, por exemplo, o Instituto Federal do Paraná que constituído por desmembramento da escola Técnica vinculada à Universidade Federal do Paraná.

Para além das questões práticas referentes a patrimônio e acervo, outras questões devem ser consideradas, em especial, a cultura escolar e o comportamento do corpo docente e técnicos administrativos face a nova realidade. Vale ressaltar, que dentre as unidades preexistentes muitas eram instituições centenárias, ocupando prédios antigos. Com a expansão, novas unidades foram construídas ocupadas por professores e técnicos recém concursados. O que pode levar a criação de classes, novatos e veteranos, entre as unidades.

Outro aspecto a ser considerado refere-se especificamente as unidades que incorporaram Escolas Agrotécnicas Federais. Estas escolas agrotécnicas estão localizadas fora da cidade, no campo, ocupam fazendas e precisam lidar com uma rotina atípica para as outras unidades urbanas e industriais da rede: a lida com rebanhos e plantações, regime didático de alternância, funcionamento 24 horas, internato para alunos. Ou seja, a fusão, aparentemente simples no marco legal, trouxe novos elementos desafiadores ao dia-a-dia escolar e as novas finalidades atribuídas aos Institutos.

$\mathrm{Na}$ Tabela 5 estão listadas as sete configurações que originaram os atuais Institutos Federais.

Tabela 5-Configurações institucionais de origem dos atuais Institutos Federais

\begin{tabular}{l|ll}
\hline Núm. & Quanto a origem & Institutos Federais \\
\hline & & IF de Alagoas \\
& IF do Amazonas \\
& IF do Ceará \\
\hline
\end{tabular}




\begin{tabular}{|c|c|c|}
\hline Núm. & Quanto a origem & Institutos Federais \\
\hline & $\begin{array}{l}\text { Por fusão e transformação de Centro Federal de } \\
\text { Educação Profissional e Tecnológica e Escola } \\
\text { Agrotécnica Federal }\end{array}$ & $\begin{array}{l}\text { IF do Espírito Santo } \\
\text { IF Goiano } \\
\text { IF do maranhão } \\
\text { IF de Minas Gerais } \\
\text { IF do Norte de Minas } \\
\text { IF do Sudeste de } \\
\text { Minas } \\
\text { IF do Triângulo mineiro } \\
\text { IF do Mato Grosso } \\
\text { IF do Pará } \\
\text { IF da Paraíba } \\
\text { IF de Pernambuco } \\
\text { IF Farroupilha } \\
\text { IF Sergipe }\end{array}$ \\
\hline 2 & Por transformação de Escola Técnica Federal & $\begin{array}{l}\text { IF do Acre } \\
\text { IF do Amapá } \\
\text { IF de Brasília }\end{array}$ \\
\hline 3 & $\begin{array}{l}\text { Por transformação de Centro Federal de } \\
\text { Educação Profissional e Tecnológica }\end{array}$ & $\begin{array}{l}\text { IF da Bahia } \\
\text { IF de Goiás } \\
\text { IF do Sertão } \\
\text { Pernambucano } \\
\text { IF do Piauí } \\
\text { IF do Rio de Janeiro } \\
\text { IF Fluminense }\end{array}$ \\
\hline
\end{tabular}




\begin{tabular}{|c|c|c|}
\hline Núm. & Quanto a origem & Institutos Federais \\
\hline & & $\begin{array}{l}\text { IF do Rio Grande do } \\
\text { Norte } \\
\text { IF Sul-Rio-Grandense } \\
\text { IF de Roraima } \\
\text { IF de Santa Catarina } \\
\text { IF de São Paulo }\end{array}$ \\
\hline 4 & $\begin{array}{l}\text { Por fusão e transformação de Escolas } \\
\text { Agrotécnicas Federais }\end{array}$ & $\begin{array}{l}\text { IF Baiano } \\
\text { IF Sul de Minas } \\
\text { IF Catarinense }\end{array}$ \\
\hline 5 & $\begin{array}{l}\text { Por fusão e transformação Escola Agrotécnica } \\
\text { Federal e Escola Técnica Federal }\end{array}$ & $\begin{array}{l}\text { IF de Rondônia } \\
\text { IF do Mato Grosso do } \\
\text { Sul } \\
\text { IF do Tocantins }\end{array}$ \\
\hline 6 & $\begin{array}{l}\text { Por transformação da Escola Técnica vinculada à } \\
\text { Universidade Federal }\end{array}$ & IF do Paraná \\
\hline 7 & $\begin{array}{l}\text { Por fusão e transformação de Centro Federal de } \\
\text { Educação Profissional e Tecnológica, Escola } \\
\text { Agrotécnica Federal e Escola Técnica Federal }\end{array}$ & $\begin{array}{l}\text { IF do Rio Grande do } \\
\text { Sul }\end{array}$ \\
\hline
\end{tabular}

Fonte: elaboração da autora a partir da revisão do marco legal.

\subsubsection{CATEGORIA DE ANÁLISE: QUANTIDADE DE CAMPI}

A expansão vivenciada pela rede de Institutos Federais, da ordem de $300 \%$, incorporou um componente adicional de complexidade à gestão escolar: 0 número de novos campi incorporados à estrutura preexistente (Tabela 6). 
O esforço de interiorização requereu, inicialmente, a construção ou reforma de unidades escolares e posteriormente a sua efetiva implementação com o início de sua oferta educativa.

Em 2013, dez (10) Institutos Federais possuíam acima de dez (10) campi (Tabela 6). Destaque-se o instituto de São Paulo com vinte e oito (28), e o instituto do Maranhão com dezoito (18) campi.

Vinte e quatro (24) institutos dispunham, em sua estrutura administrativa e acadêmica, um total de campi entre cinco e dez unidades. Ou seja, a maior parte desses institutos, em 2013, estavam neste grupo.

Por fim, apenas sete (04) institutos contavam com número de unidades no intervalo de 2 a 4 .

Devem ser considerados nesta análise o esforço e dificuldade na gestão, em aspectos tais como: definição do tipo da oferta educativa e sua adesão ao entorno sócio produtivo, estruturação curricular, definição do projeto pedagógico da escola, montagem de laboratórios e mobiliário, realização de concurso público para corpo docente e técnicos administrativos, acolhida e capacitação do corpo social da unidade, nomeação de gestores para os cargos de direção. Tais aspectos relacionados ao "nascer" de uma escola de educação profissional somados a manutenção das unidades preexistentes em cada instituto federal, sugerem consequentes impactos na qualidade da oferta, que pode vir a ser tema de estudos futuros.

Tabela 6-Quantitativo de campi por Institutos Federais

\begin{tabular}{l|lr}
\hline Instituição & Sede & $\begin{array}{r}\text { Qtde de } \\
\text { Campi }\end{array}$ \\
\hline Instituto Federal de São Paulo & São Paulo & 28 \\
Instituto Federal do Maranhão & São Luís & 18 \\
Instituto Federal de Santa Catarina & Florianópolis & 17 \\
Instituto Federal do Espírito Santo & Vitoria & 17 \\
Instituto Federal do Rio Grande do Norte & Natal & 14 \\
Instituto Federal do Ceará & Fortaleza & 12 \\
Instituto Federal do Paraná & Curitiba & 12 \\
Instituto Federal de Alagoas & Maceió & 11 \\
Instituto Federal do Pará & Belém & 11
\end{tabular}




\begin{tabular}{l|lr}
\hline Instituição & Sede & $\begin{array}{r}\text { Qtde de } \\
\text { Campi }\end{array}$ \\
\hline Instituto Federal do Rio Grande do Sul & Porto Alegre & 11 \\
Instituto Federal Catarinense & Blumenau & 10 \\
Instituto Federal de Mato Grosso & Cuiabá & 10 \\
Instituto Federal do Amazonas & Manaus & 10 \\
Instituto Federal do Piauí & Teresina & 10 \\
Instituto Federal do Rio de Janeiro & Rio de Janeiro & 10 \\
Instituto Federal Baiano & Salvador & 9 \\
Instituto Federal da Bahia & Salvador & 9 \\
Instituto Federal da Paraíba & João Pessoa & 9 \\
Instituto Federal de Pernambuco & Recife & 9 \\
Instituto Federal de Goiás & Goiânia & 8 \\
Instituto Federal Sul-Rio-Grandense & Pelotas & 8 \\
Instituto Federal de Brasília & Brasília & 7 \\
Instituto Federal de Mato Grosso do Sul & Campo Grande & 7 \\
Instituto Federal do Norte de Minas Gerais & Montes Claros & 7 \\
Instituto Federal Farroupilha & Santa Maria \\
Instituto Federal Fluminense & Campo dos Goytacazes & 7 \\
Instituto Federal de Minas Gerais & Belo Horizonte & 7 \\
Instituto Federal de Rondônia & Porto Velho & 6 \\
Instituto Federal de Sergipe & Aracaju & 6 \\
Instituto Federal de Tocantins & Palmas & 6 \\
Instituto Federal do Sudeste de Minas Gerais & Juiz de Fora & 6 \\
Instituto Federal do Sul de Minas Gerais & Pouso Alegre & 6 \\
Instituto Federal do Triângulo Mineiro & Uberaba & 6 \\
Instituto Federal Goiano & Goiânia & 5 \\
Instituto Federal do Sertão Pernambucano & Petrolina & 5 \\
Instituto Federal de Roraima & Boa Vista & 3 \\
Instituto Federal do Acre & Rio Branco & 2 \\
Instituto Federal do Amapá & Macapá & \\
\hline Total geral & & 546 \\
\hline & & 5
\end{tabular}

Fonte: Elaboração da autora a partir de dados SISTEC/MEC.

\subsubsection{CATEGORIA DE ANÁLISE: MAIOR RAIO DE ABRANGÊNCIA}

Em complemento à categoria de análise descrita anteriormente, outro aspecto está relacionado ao desafio de um instituto federal multicampi: o seu raio de 
abrangência, ou o seu limite máximo de distância entre sua sede e seu campus mais distante. Na Tabela estão listadas a maior distância existente entre a sede do instituto federal e o seu campus mais longínquo.

Em 2013, onze (11) Institutos Federais possuíam, em sua estrutura administrativa e acadêmica, campus distantes da sede acima de $500 \mathrm{KM}$. Neste grupo, merece destaque a distância entre a sede do Instituto Federal do Amazonas, Manaus, e seu campus de Tabatinga/Am: $1607 \mathrm{Km}$ fluviais, o que representa uma viagem de cinco (05) dias e cinco (05) noites de barco. Os Institutos Federais do Mato Grosso e do Pará tem igualmente um limite superior de distância entre a sede e o campus mais longínquo de cerca $1000 \mathrm{~km}$, respectivamente a distância de Cuiabá/MT ao campus de Confresa/MT e de Belém/PA até o campus de Conceição do Araguaia/PA.

No intervalo de 200 a 500 KM para a distância máxima entre a sede do instituto federal e seu campus mais distante, são listados vinte (20) institutos, conforme tabela seguinte. Contudo, mesmo nesta faixa de distância, por vezes o acesso ao campus remoto apresenta dificuldades, é o caso do Instituto Federal do Amapá, onde sua sede Macapá fica distante $265 \mathrm{Km}$ do campus Laranjal do Jari/AP, porém, o acesso é feito em grande parte por estrada de terra fazendo com que o trajeto, quando possível, seja executado em 6 horas de viagem. Por fim, sete (07) Institutos Federais distam até $200 \mathrm{~km}$ entre sede e campus mais afastado. A melhor situação em casos de menor distância entre unidades é vivenciada pelo Instituto Federal de Brasília, com maior de distância de $43 \mathrm{KM}$ e acesso rodoviário facilitado.

Este cenário, número de campi elevado, grandes distâncias e consequente tempo elevado de deslocamentos é outra externalidade trazida pela expansão e, principalmente, por sua característica de interiorização, num país com dimensões continentais como o Brasil. A questão que se coloca é: como os Institutos Federais fazem par lidar com esta característica? Quais estratégias utilizadas para rotinas de visita e uniformização de procedimentos? Foram incorporadas soluções inovadoras de comunicação à rotina dos IF? O conceito de pertencimento ao IF é presente em todas as suas unidades? Ou percebe-se um isolamento? São questões advindas da análise dos dados e passíveis de resposta por estudos futuros. 
Tabela 7-Maior distância entre Sede e Campus dos Institutos Federais

\begin{tabular}{|c|c|c|}
\hline Instituição & Sede & $\begin{array}{l}\text { Maior distância } \\
(\text { em } \mathrm{Km})\end{array}$ \\
\hline Instituto Federal do Amazonas & Manaus & 1607 \\
\hline Instituto Federal de Mato Grosso & Cuiabá & 1008 \\
\hline Instituto Federal do Pará & Belém & 1000 \\
\hline Instituto Federal do Piauí & Teresina & 843 \\
\hline Instituto Federal de Rondônia & Porto Velho & 761 \\
\hline Instituto Federal do Maranhão & São Luís & 708 \\
\hline Instituto Federal de Santa Catarina & Florianópolis & 655 \\
\hline Instituto Federal de São Paulo & São Paulo & 644 \\
\hline Instituto Federal do Paraná & Curitiba & 635 \\
\hline Instituto Federal de Tocantins & Palmas & 612 \\
\hline Instituto Federal do Ceará & Fortaleza & 507 \\
\hline Instituto Federal da Bahia & Salvador & 490 \\
\hline Instituto Federal Sul-Rio-Grandense & Pelotas & 490 \\
\hline Instituto Federal da Paraíba & João Pessoa & 476 \\
\hline Instituto Federal do Norte de Minas Gerais & Montes Claros & 459 \\
\hline Instituto Federal de Mato Grosso do Sul & Campo Grande & 429 \\
\hline Instituto Federal do Rio Grande do Norte & Natal & 392 \\
\hline Instituto Federal Catarinense & Blumenau & 390 \\
\hline Instituto Federal do Triângulo Mineiro & Uberaba & 379 \\
\hline Instituto Federal de Pernambuco & Recife & 370 \\
\hline Instituto Federal de Goiás & Goiânia & 320 \\
\hline Instituto Federal do Rio Grande do Sul & Porto Alegre & 319 \\
\hline Instituto Federal do Sul de Minas Gerais & Pouso Alegre & 319 \\
\hline Instituto Federal Farroupilha & Santa Maria & 296 \\
\hline Instituto Federal de Minas Gerais & Belo Horizonte & 285 \\
\hline Instituto Federal de Alagoas & Maceió & 278 \\
\hline Instituto Federal do Amapá & Macapá & 265 \\
\hline Instituto Federal do Espírito Santo & Vitoria & 247 \\
\hline Instituto Federal do Sertão Pernambucano & Petrolina & 236 \\
\hline Instituto Federal Goiano & Goiânia & 232 \\
\hline Instituto Federal Baiano & Salvador & 226 \\
\hline Instituto Federal Fluminense & Campo dos Goytacazes & 191 \\
\hline Instituto Federal do Rio de Janeiro & Rio de Janeiro & 163 \\
\hline Instituto Federal de Roraima & Boa Vista & 156 \\
\hline $\begin{array}{l}\text { Instituto Federal do Sudeste de Minas } \\
\text { Gerais }\end{array}$ & Juiz de Fora & 155 \\
\hline Instituto Federal do Acre & Rio Branco & 144 \\
\hline Instituto Federal de Sergipe & Aracaju & 118 \\
\hline Instituto Federal de Brasília & Brasília & 43 \\
\hline
\end{tabular}

Fonte: Elaboração da autora a partir de dados SISTEC/MEC e DETRAN. 


\subsubsection{CATEGORIA DE ANÁLISE: GRAUS DE ESPECIALIZAÇÃO DA REDE}

Nesta categoria são apresentados os eixos tecnológicos nos quais a rede federal de Institutos Federais concentra a oferta de seus cursos, tomando como base a oferta do ano de 2013, fonte: SISTEC/MEC.

Os eixos tecnológicos consideram para a organização dos cursos as matrizes de tecnologias simbólicas, físicas e organizacionais associadas ao desenvolvimento de determinado produto, bem, processo ou serviço. Esta classificação implica o resgate do histórico e da lógica do desenvolvimento dos conhecimentos científico- -tecnológicos imbricados nesses conjuntos de tecnologias. Esse mapeamento possibilita a identificação de diferentes formações profissionais que se encontram associadas dentro de um eixo tecnológico ou mesmo entre eixos, isto é, permite a estruturação de itinerários formativos.

O planejamento da oferta em eixos tecnológicos deve considerar a sintonia com o entorno sócio produtivo, a otimização de corpo docente e infraestrutura laboratorial e o fomento à verticalidade. Entende-se por verticalidade na oferta de educação profissional, a possibilidade oferecida ao estudante de percorrer um itinerário formativo em uma unidade da rede federal, partindo de cursos de menor complexidade e avançando em sua escolaridade.

Da análise dos Gráfico 5 e Gráfico 6, percebe-se que o conjunto de Institutos Federais concentra, ainda de forma majoritária, sua oferta na base das ciências exatas, considerando os eixos tecnológicos de "Controle e Processos Industriais", "Produção Industrial", "Infraestrutura" e "Tecnologia e Comunicação". E tem sua segunda maior oferta nos eixos de "Recursos Naturais" e "Produção Alimentícia". Caracterizando, na matriz de oferta de cursos em 2013, de forma eloquente, os matizes originais da composição da rede federal. 
Gráfico 5-Distribuição da oferta de cursos por Eixo Tecnológico, em 2013 Qtd. de cursos

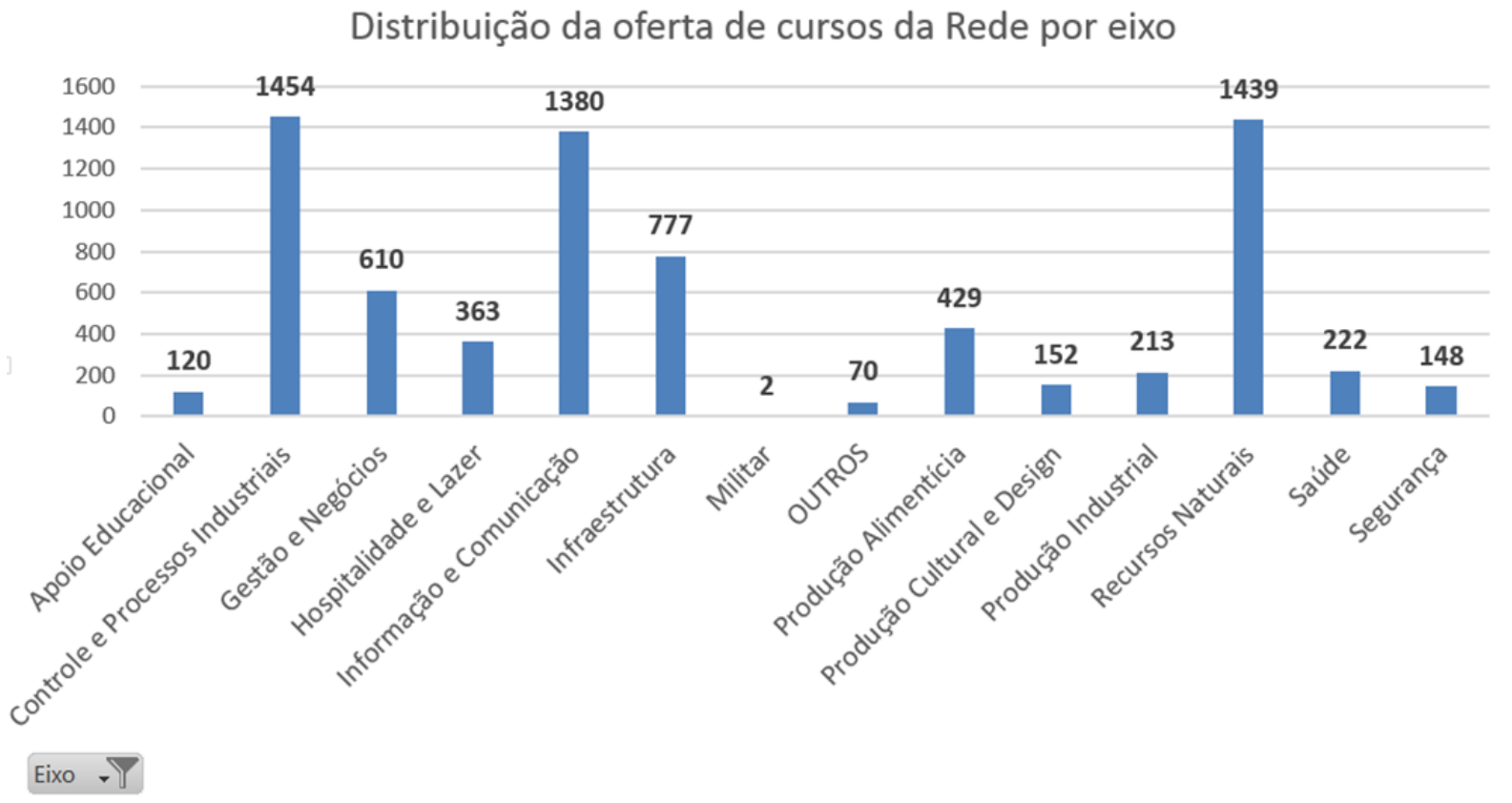

Fonte: Elaboração da autora a partir do cruzamento de dados SISTEC/MEC.

Gráfico 6-Distribuição da oferta de cursos por grupos de Eixos Tecnológicos, em 2013 


\section{Distribuição da oferta de cursos da Rede por agrupamento de eixos}

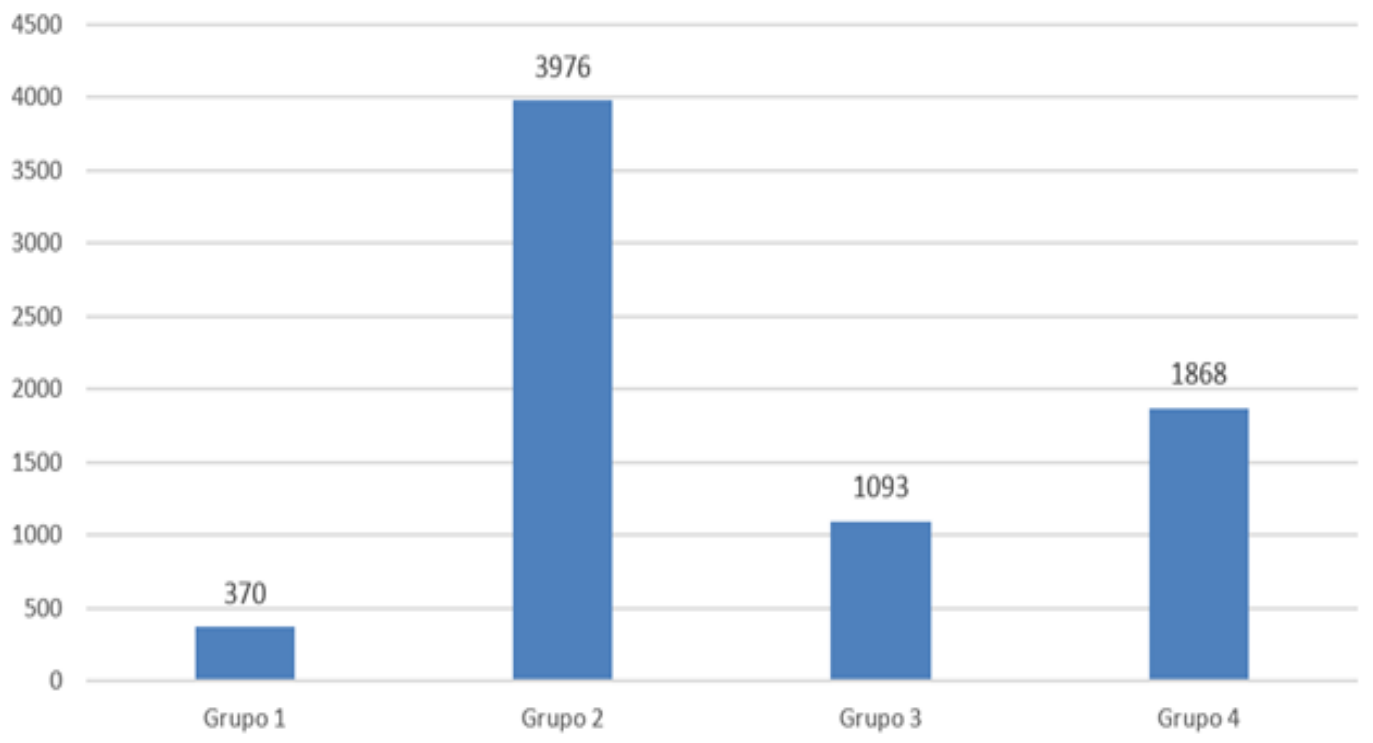

Agrupamento de eixos - $Y$

Legenda

G 1 - Saúde e Segurança

G 2 - Infraestrutura, Info. e Comunicação, Controle e Processos Industriais e Prod. Industrial

G 3 - Hospi. e Lazer, Gestão e Negócios e Apoio educacional

G 4 - Recursos Naturais e Produção Alimentícia

Fonte: Elaboração da autora a partir do cruzamento de dados SISTEC/MEC.

\subsubsection{CATEGORIA DE ANÁLISE: OFERTA EDUCATIVA}

Em 2013 a distribuição de matrículas e cursos entre os níveis da educação profissional e tecnológica da Rede Federal - em seu conjunto de unidades - caracterizou-se pela oferta de $52 \%$ de cursos técnicos de nível médio, $26 \%$ de oferta de cursos de graduação, $18 \%$ de oferta de cursos de formação inicial e continuada e $4 \%$ distribuídos em outros tipos de oferta, conforme Gráfico 7. Assim, conclui-se que em termos percentuais houve cumprimento da destinação de, no mínimo, $50 \%$ para a oferta de cursos técnicos. 
Gráfico 7-Distribuição do grau da oferta de cursos nos Institutos Federais, em 2013

\section{Distribuição da oferta de cursos da Rede por modalidade}
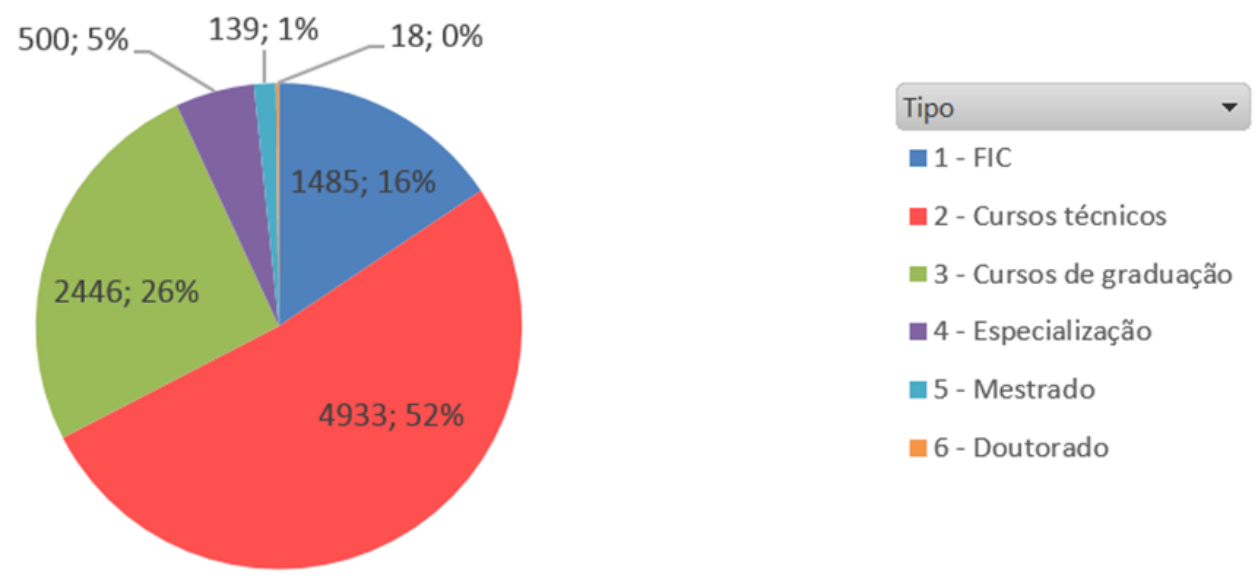

Fonte: Elaboração da autora a partir de dados SISTEC/MEC.

O Gráfico 8 e o Gráfico 9 apresentam a distribuição da oferta educativa dos Institutos Federais, quanto a cursos técnicos de nível médio e cursos de graduação respectivamente. Os Institutos Federais do Pará, São Paulo, Maranhão, Santa Catarina, Pernambuco e Espírito Santo apresentaram a maior quantidade de ciclos de matrículas em cursos técnicos de nível médio. No caso do Instituto Federal do Pará a oferta elevada foi, sobremaneira, impulsionada por cursos técnicos na modalidade EaD. 
Gráfico 8-Distribuição da oferta de cursos técnicos nos Institutos Federais, em 2013

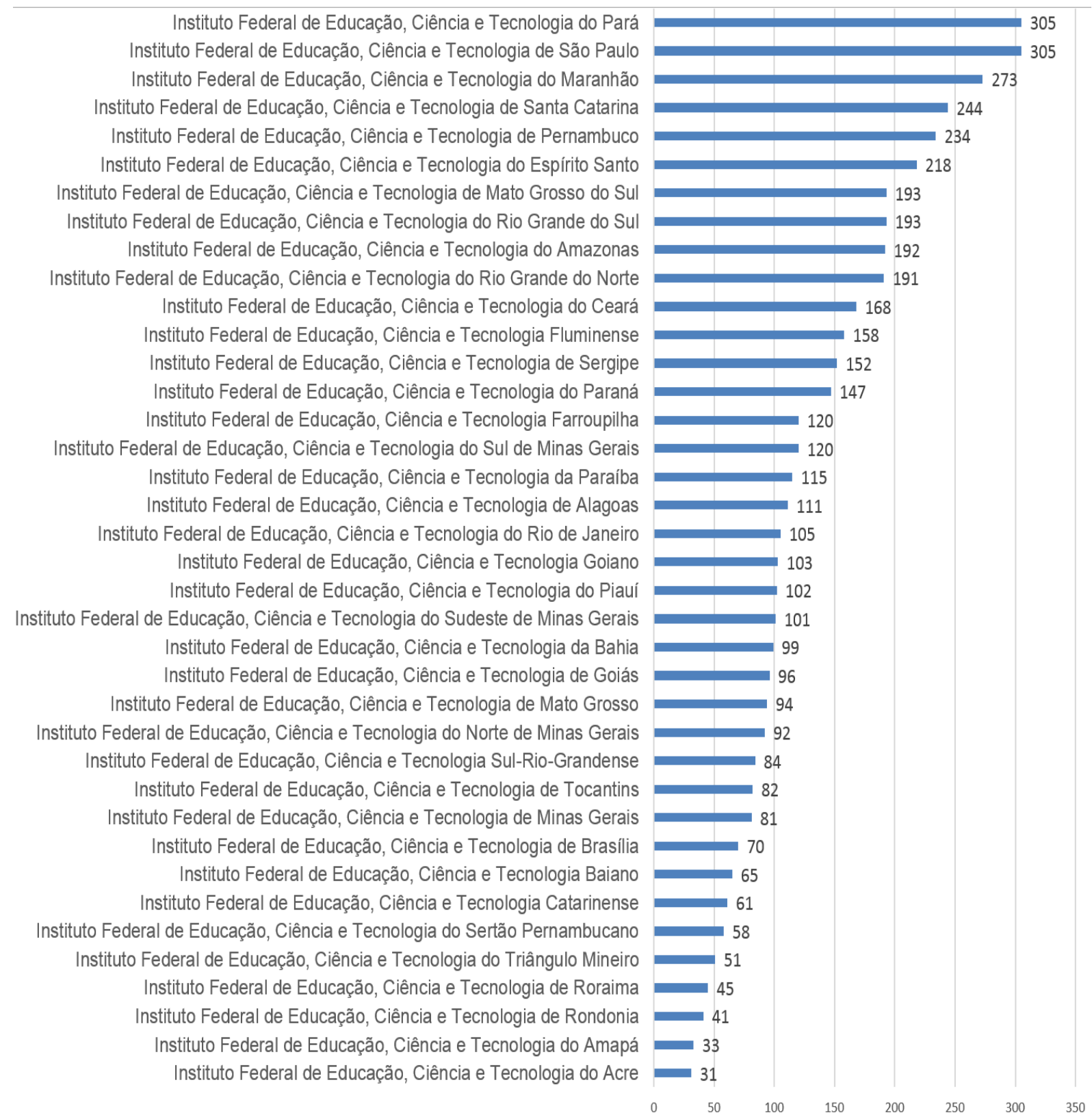

Fonte: Elaboração da autora a partir de dados SISTEC/MEC. 


\section{Gráfico 9-Distribuição da oferta de cursos de graduação nos Institutos Federais, em 2013}

\footnotetext{
Instituto Federal de Educação, Ciência e Tecnologia do Rio Grande do Norte Instituto Federal de Educação, Ciência e Tecnologia de São Paulo Instituto Federal de Educação, Ciência e Tecnologia do Pará Instituto Federal de Educação, Ciência e Tecnologia do Ceará Instituto Federal de Educação, Ciência e Tecnologia de Santa Catarina Instituto Federal de Educação, Ciência e Tecnologia da Paraíba Instituto Federal de Educação, Ciência e Tecnologia do Maranhão Instituto Federal de Educação, Ciência e Tecnologia de Goiás Instituto Federal de Educação, Ciência e Tecnologia do Rio Grande do Sul Instituto Federal de Educação, Ciência e Tecnologia Goiano Instituto Federal de Educação, Ciência e Tecnologia do Espírito Santo Instituto Federal de Educação, Ciência e Tecnologia de Mato Grosso do Sul

Instituto Federal de Educação, Ciência e Tecnologia do Rio de Janeiro Instituto Federal de Educação, Ciência e Tecnologia Fluminense Instituto Federal de Educação, Ciência e Tecnologia de Mato Grosso Instituto Federal de Educação, Ciência e Tecnologia do Norte de Minas Gerais Instituto Federal de Educação, Ciência e Tecnologia de Sergipe Instituto Federal de Educação, Ciência e Tecnologia Farroupilha Instituto Federal de Educação, Ciência e Tecnologia Sul-Rio-Grandense

Instituto Federal de Educação, Ciência e Tecnologia de Pernambuco Instituto Federal de Educação, Ciência e Tecnologia do Sul de Minas Gerais Instituto Federal de Educação, Ciência e Tecnologia do Piaú Instituto Federal de Educação, Ciência e Tecnologia do Paraná Instituto Federal de Educação, Ciência e Tecnologia de Alagoas Instituto Federal de Educação, Ciência e Tecnologia do Amazonas Instituto Federal de Educação, Ciência e Tecnologia de Minas Gerais Instituto Federal de Educação, Ciência e Tecnologia do Sudeste de Minas Gerais Instituto Federal de Educação, Ciência e Tecnologia de Tocantins Instituto Federal de Educação, Ciência e Tecnologia Catarinense Instituto Federal de Educação, Ciência e Tecnologia do Sertão Pernambucano Instituto Federal de Educação, Ciência e Tecnologia de Brasília Instituto Federal de Educação, Ciência e Tecnologia Baiano Instituto Federal de Educação, Ciência e Tecnologia do Triângulo Mineiro Instituto Federal de Educação, Ciência e Tecnologia de Rondonia Instituto Federal de Educação, Ciência e Tecnologia da Bahia Instituto Federal de Educação, Ciência e Tecnologia de Roraima Instituto Federal de Educação, Ciência e Tecnologia do Acre Instituto Federal de Educação, Ciência e Tecnologia do Amapá

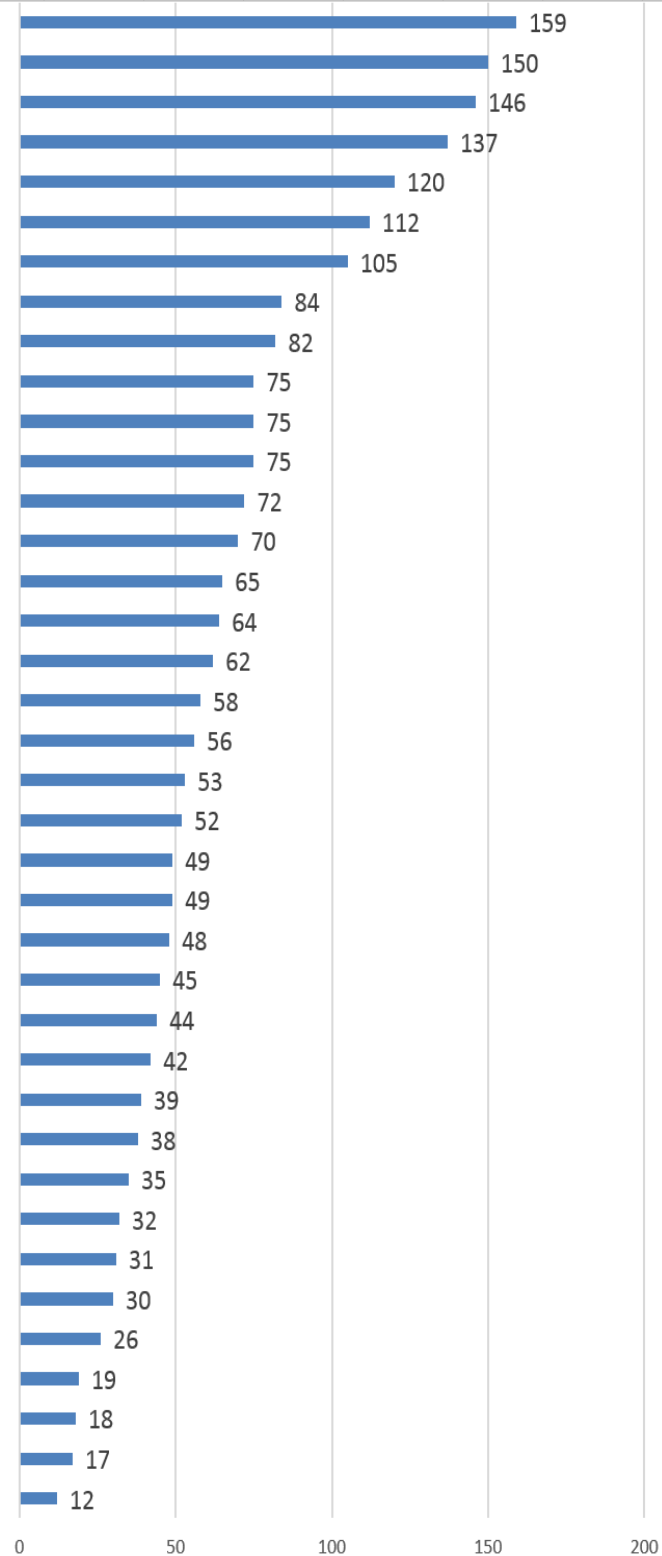

Fonte: Elaboração da autora a partir de dados SISTEC/MEC.

Por fim, merece destaque nesta categoria de análise, a proporcionalidade da oferta entre cursos técnicos e cursos de graduação calculada para cada Instituto Federal. No Gráfico 10 estão dispostos os fatores encontrados entre estas ofertas. 
Por exemplo, o Instituto Federal da Bahia, listado no topo do referido gráfico, apresenta o fator de 5,2 (cinco vírgula dois), ou seja, este Instituto dispõe de uma oferta de cursos técnicos maior em 5,2 vezes a oferta de cursos de graduação. Ainda observando o mesmo gráfico percebe-se que o Instituto Federal da Paraíba dispõe da mesma proporcionalidade entre cursos técnicos e de graduação, tendo em vista o seu fator listado no gráfico ser igual a 1 (um).

Gráfico 10-Distribuição da proporção de ofertas de cursos técnicos em relação a oferta de cursos de graduação por Instituto Federal, em 2013

Proporção de ofertas de cursos técncios em relação aos de cursos de graduação po IFs

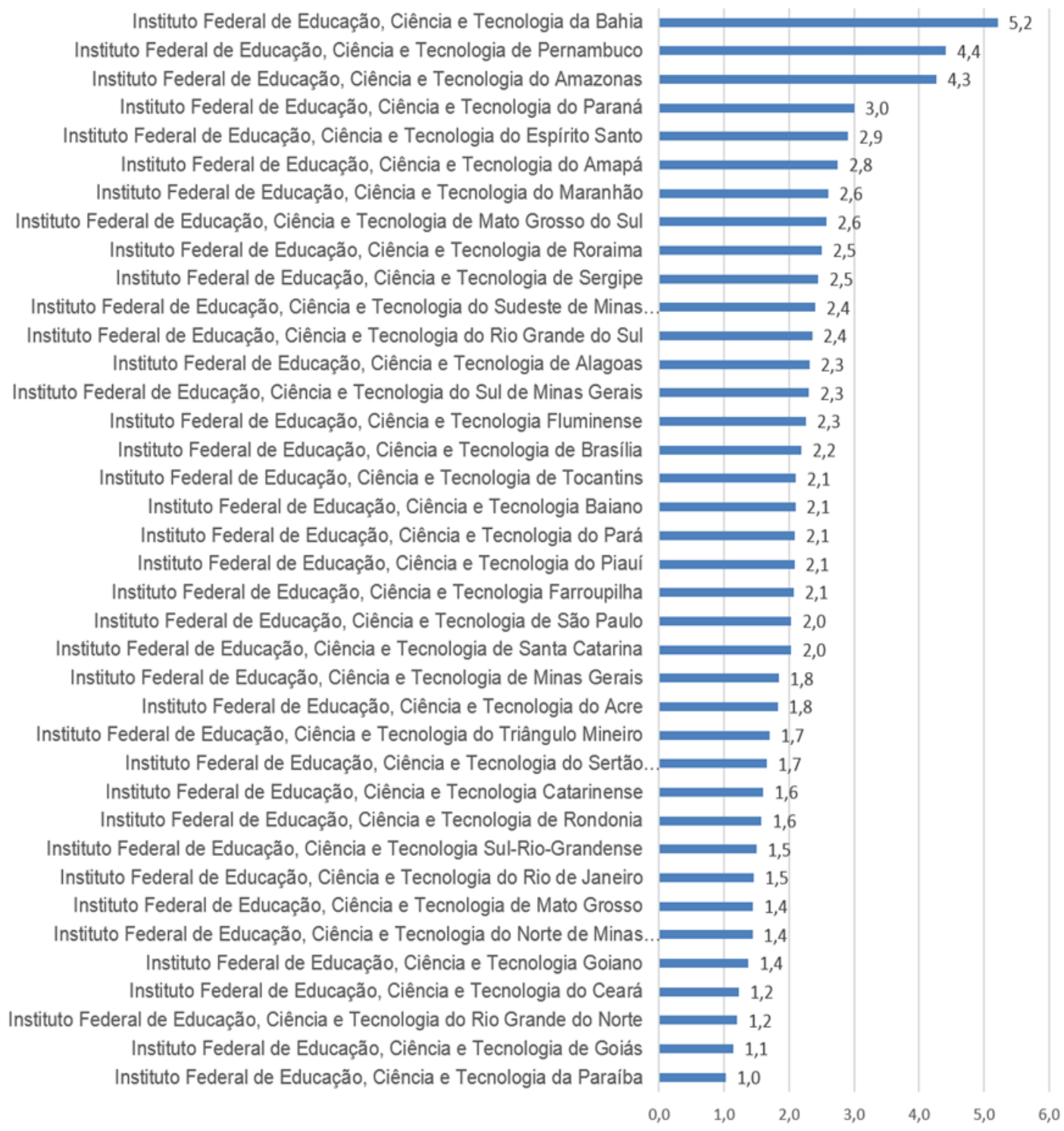

Fonte: Elaboração da autora a partir de dados SISTEC/MEC. 
Com relação a modalidade da oferta de cursos, no ano de 2013, ela foi predominantemente presencial (Gráfico 11). A oferta de cursos a distância representou apenas $6 \%$ do total.

Gráfico 11-Distribuição da modalidade de oferta (Presencial ou EaD) de cursos nos Institutos Federais, em 2013

\section{Distribuição da oferta de} cursos da Rede por tipo

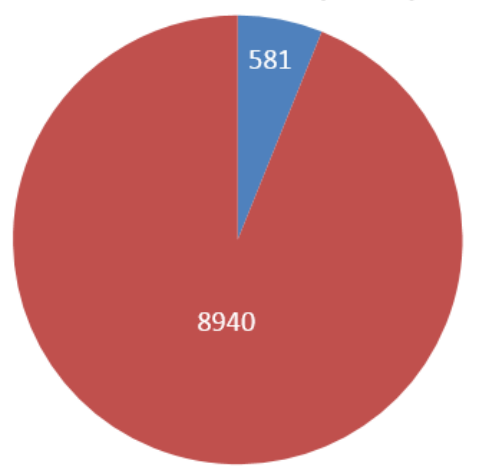

Tipo de Curso

口 A Distância

- Presencial

Fonte: Elaboração da autora a partir de dados SISTEC/MEC.

\subsubsection{CATEGORIA DE ANÁLISE: TITULAÇÃO}

Nesta categoria, estão tabuladas informações referente à titulação do corpo social dos Institutos Federais, aqui representados por seus docentes e técnicos administrativos. A característica marcante da análise destes dados é a alta titulação do corpo docente dos Institutos Federais.

Da análise dos dados, percebe-se que 0 total de professores com mestrado e doutorado representa, no pior caso, $40,6 \%$ do total do efetivo de docentes, dados do Instituto Federal do Acre e alcança os $93,1 \%$ no Instituto Federal 
do Espírito Santo, o Instituto mais bem posicionado com relação a titulação docente - Tabela 8.

Com relação ao percentual de doutores na rede federal, os números, a exceção dos Institutos dos Estados do Norte, também são bastante favoráveis. $\mathrm{Na}$ rede federal o maior percentual de docentes com doutorado está no Estado do Espírito Santo, com 39,7\% dos docentes com doutorado. E as piores proporções, tratando-se da titulação dos docentes com doutorado são respectivamente: IF de Roraima com 2,5\% e IF do Amapá com nenhum docente possuidor do título de doutor.

Vale ressaltar que o alto percentual de titulação da rede federal teve estímulos de quatro ordens: (i) incentivo institucional para afastamento e curso de pós-graduação para os docentes em exercício; (ii) incentivo para implantação de programas próprios de pós-graduação na própria rede; (iii) incentivo a programas de pós-graduação que utilizassem estratégias de educação a distância; e por fim (iv) a seleção por concurso público, sendo uma das etapas de seleção, a pontuação da titulação dos candidatos.

Tabela 8-Titulação do corpo docente nos Institutos Federais.

\begin{tabular}{l|rr}
\hline Instituição & $\begin{array}{r}\text { \% Mestres } \\
\text { e Doutores }\end{array}$ & \% Doutores \\
\hline Instituto Federal Baiano & $78,90 \%$ & $26,10 \%$ \\
Instituto Federal Catarinense & $87,80 \%$ & $29,10 \%$ \\
Instituto Federal da Bahia & $64,90 \%$ & $19,80 \%$ \\
Instituto Federal da Paraíba & $81,60 \%$ & $25,60 \%$ \\
Instituto Federal de Alagoas & $75,60 \%$ & $15,80 \%$ \\
Instituto Federal de Brasília & $86,20 \%$ & $30,30 \%$ \\
Instituto Federal de Goiás & $75,00 \%$ & $18,80 \%$ \\
Instituto Federal de Mato Grosso & $78,70 \%$ & $24,40 \%$ \\
Instituto Federal de Mato Grosso do Sul & $60,90 \%$ & $11,30 \%$ \\
Instituto Federal de Minas Gerais & $73,80 \%$ & $24,40 \%$ \\
Instituto Federal de Pernambuco & $66,60 \%$ & $15,70 \%$ \\
Instituto Federal de Rondônia & $51,10 \%$ & $8,90 \%$ \\
Instituto Federal de Roraima & $45,90 \%$ & $2,50 \%$ \\
Instituto Federal de Santa Catarina & $83,70 \%$ & $31,00 \%$ \\
Instituto Federal de São Paulo & $84,10 \%$ & $30,30 \%$ \\
Instituto Federal de Sergipe & $87,10 \%$ & $23,30 \%$ \\
Instituto Federal de Tocantins & $47,30 \%$ & $12,50 \%$
\end{tabular}




\begin{tabular}{l|rr}
\hline Instituição & $\begin{array}{r}\text { \% Mestres } \\
\text { e Doutores }\end{array}$ & \% Doutores \\
\hline Instituto Federal do Acre & $40,60 \%$ & $7,10 \%$ \\
Instituto Federal do Amapá & $43,30 \%$ & $0,00 \%$ \\
Instituto Federal do Amazonas & $78,30 \%$ & $29,10 \%$ \\
Instituto Federal do Ceará & $67,20 \%$ & $16,90 \%$ \\
Instituto Federal do Espírito Santo & $82,90 \%$ & $39,70 \%$ \\
Instituto Federal do Maranhão & $59,20 \%$ & $16,20 \%$ \\
Instituto Federal do Norte de Minas Gerais & $57,40 \%$ & $13,30 \%$ \\
Instituto Federal do Pará & $45,20 \%$ & $10,80 \%$ \\
Instituto Federal do Paraná & $76,10 \%$ & $20,40 \%$ \\
Instituto Federal do Piauí & $55,80 \%$ & $11,40 \%$ \\
Instituto Federal do Rio de Janeiro & $87,90 \%$ & $38,40 \%$ \\
Instituto Federal do Rio Grande do Norte & $73,50 \%$ & $22,30 \%$ \\
Instituto Federal do Rio Grande do Sul & $90,60 \%$ & $33,30 \%$ \\
Instituto Federal do Sertão Pernambucano & $52,20 \%$ & $11,30 \%$ \\
Instituto Federal do Sudeste de Minas Gerais & $80,40 \%$ & $26,60 \%$ \\
Instituto Federal do Sul de Minas Gerais & $78,30 \%$ & $33,30 \%$ \\
Instituto Federal do Triângulo Mineiro & $82,60 \%$ & $37,30 \%$ \\
Instituto Federal Farroupilha & $93,10 \%$ & $32,30 \%$ \\
Instituto Federal Fluminense & $71,40 \%$ & $27,70 \%$ \\
Instituto Federal Goiano & $82,00 \%$ & $34,90 \%$ \\
Instituto Federal Sul-Rio-Grandense & $74,10 \%$ & $25,30 \%$ \\
\hline
\end{tabular}

Fonte: Elaboração da autora a partir do cruzamento de dados Censo INEP.

Quantitativamente, estão em exercício nos Institutos Federais 383.683 funções docentes dos quais 125.847 possuem título de Doutorado. Com relação aos Técnicos Administrativos a proporção é invertida, como pode-se observar, a partir da análise do Gráfico 12 e Gráfico 13. Dentre os técnicos administrativos o maior quantitativo é o de não graduados, ao 197.705 . 
Gráfico 12-Titulação das funções docentes nos Institutos Federais, em 2013

\section{Funções Docentes Rede Federal 2013 Titulação}

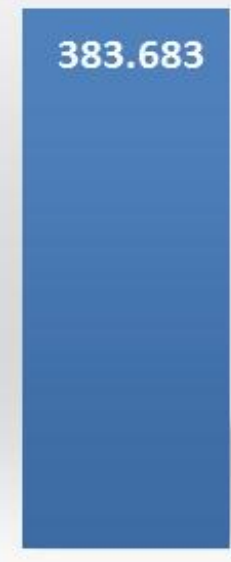

Total

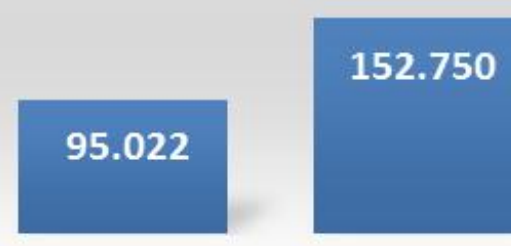

Mestrado

Especialização

\subsection{7}

10.064

Graduação

Fonte: Elaboração da autora a partir de dados do Censo INEP.

Gráfico 13-Titulação das funções docentes nos Institutos Federais, em 2013 


\section{Técnicos Administrativos Rede Federal 2013 \\ Titulação}

\subsection{6}

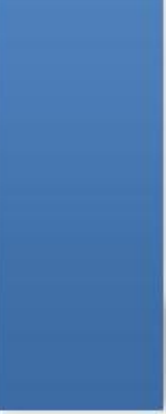

Total

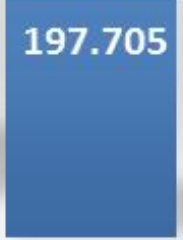

Não graduados

\subsection{4}

\section{\begin{tabular}{lll}
61.830 & 19.208 & 4.809 \\
\hline
\end{tabular}}

Graduação
Especialização Mestrado

Fonte: Elaboração da autora a partir de dados do Censo INEP.

Adicionalmente, apresenta-se a seguir a distribuição quanto ao sexo dos docentes e técnicos administrativos da rede federal de institutos - Gráfico $14 \mathrm{e}$ Gráfico 15. Observa-se, novamente, uma relação invertida. Os homens são maioria no corpo docente e as mulheres constituem-se maioria nos técnicos administrativos.

Além das observações de assimetria entre os sexos, a realidade do corpo docente, no exame dos microdados disponibilizados pelo INEP, demonstra um enfraquecimento do fenômeno de "masculinazação das exatas". Ainda menores quantitativa e percentualmente, percebe-se, ademais, um crescimento do número de docentes mulheres atuando em institutos notadamente de vocação industrial. 
Gráfico 14-Funções docentes nos Institutos Federais, por sexo, em 2013

\section{Funções Docentes - Rede Federal 2013}

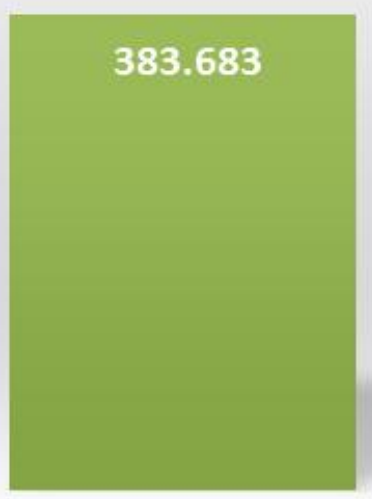

Total

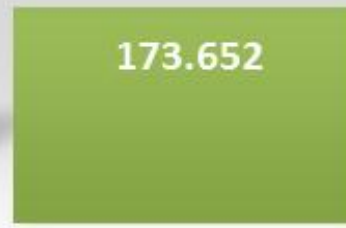

Mulheres

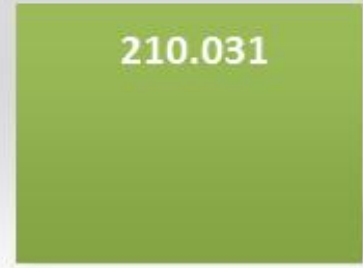

Homens

Fonte: Elaboração da autora a partir de dados do Censo INEP.

Gráfico 15-Técnicos administrativos nos Institutos Federais, por sexo, em 2013

\section{Técnicos-Administrativos - Rede Federal 2013}

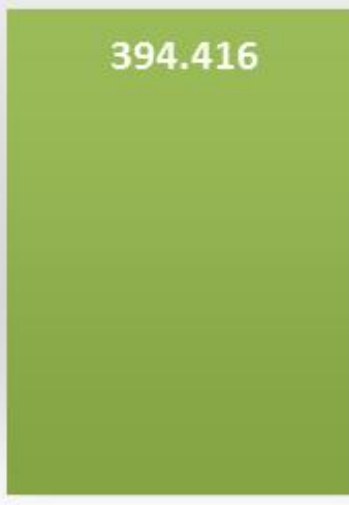

Total

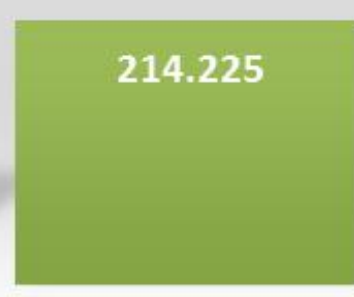

Mulheres

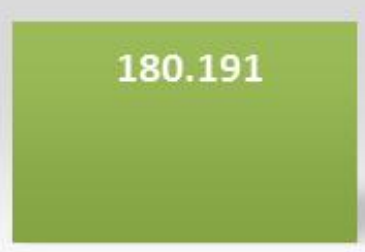

Homens

Fonte: Elaboração da autora a partir de dados do Censo INEP. 


\subsubsection{CATEGORIA DE ANÁLISE: IDEB.}

O Índice de Desenvolvimento da Educação Básica (IDEB), criado pelo Inep em 2007, é um indicador de qualidade da educação básica e reúne duas dimensões: fluxo escolar e médias de desempenho nas avaliações. Assim, sinteticamente, fornece uma visão sobre o sistema educacional das cidades. $O$ indicador é calculado a partir dos dados sobre aprovação escolar, obtidos no Censo Escolar, e médias de desempenho nas avaliações do Inep, o Saeb - para as unidades da federação e para o país, e a Prova Brasil - para os municípios.

As unidades da rede federal estão localizadas, na sua maioria em cidades que possuem um IDEB na faixa de 4 a 5,7 , conforme figura a seguir.

Figura 11-Mapa das Unidades da Rede Federal com a variável selecionada IDEB

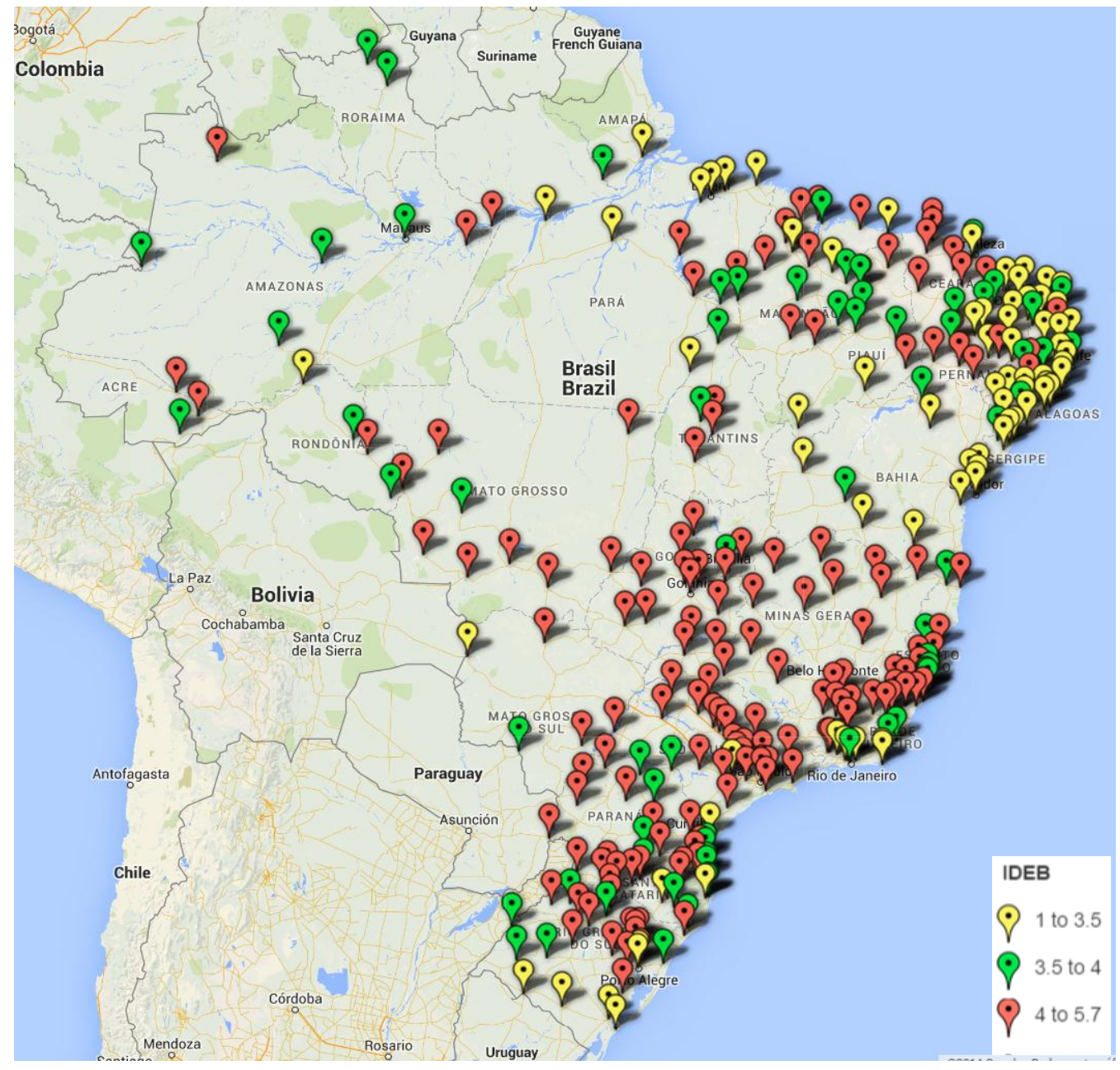

Fonte: Elaboração da autora 


\subsubsection{CATEGORIA DE ANÁLISE: IDHM}

O Índice de Desenvolvimento Humano Municipal (IDHM) é uma medida composta de indicadores de três dimensões do desenvolvimento humano: longevidade, educação e renda.

O índice varia de 0 a 1 . Quanto mais próximo de 1 , maior o desenvolvimento humano. O IDHM brasileiro segue as mesmas três dimensões do IDH Global - longevidade, educação e renda, mas vai além: adequa a metodologia global ao contexto brasileiro e à disponibilidade de indicadores nacionais. Embora meçam os mesmos fenômenos, os indicadores levados em conta no IDHM são mais adequados para avaliar o desenvolvimento dos municípios brasileiros.

$\mathrm{Na}$ sequência, serão apresentadas quatro figuras contendo mapas com as cidades onde estão situadas unidades da rede federal de institutos e os seus valores de IDHM. No primeiro mapa (Figura 12), estão plotadas todas as unidades da rede federal existentes em 2013. O segundo mapa (Figura 13), apresenta as cidades, e seus valores de IDHM, nas quais haviam unidades da rede federal preexistentes e anteriores a expansão vivenciada a partir de 2003. O terceiro mapa (Figura 14), evidencia a primeira fase da expansão de unidades dos institutos com relação ao IDHM, período de 2003 a 2010. E por fim, o quarto mapa desta seção (Figura 15), apresenta os municípios e seus valores de IDHM contemplados com a expansão de unidades ocorrida nos anos de 2011 a 2012.

Da análise dos mapas, percebe-se o esforço empreendido pela autoridade governamental no sentido de interiorizar a expansão, alcançado centros urbanos pequenos e com baixo IDHM.

Em 2002, período pré-expansão, havia apenas cinco (05) unidades de Institutos Federais localizados em municípios com IDHM na faixa de 0,484 a 0,62.

No primeiro período de expansão, período de 2003 a 2010, este número salta para dezessete (17) municípios na mesma faixa de IDHM. 
Por fim, no período de 2011 a 2012, no segundo período de expansão, foram contemplados quatorze (14) municípios na menor faixa de IDHM.

Outro ponto merecedor de destaque, foi a ocupação de cidades com indicador IHDM mediano, ou seja, aparentemente, a expansão também buscou alcançar cidades polos regionais.

Figura 12- Mapa do IDHM dos municípios onde estavam localizados os Institutos Federais existentes em 2013.

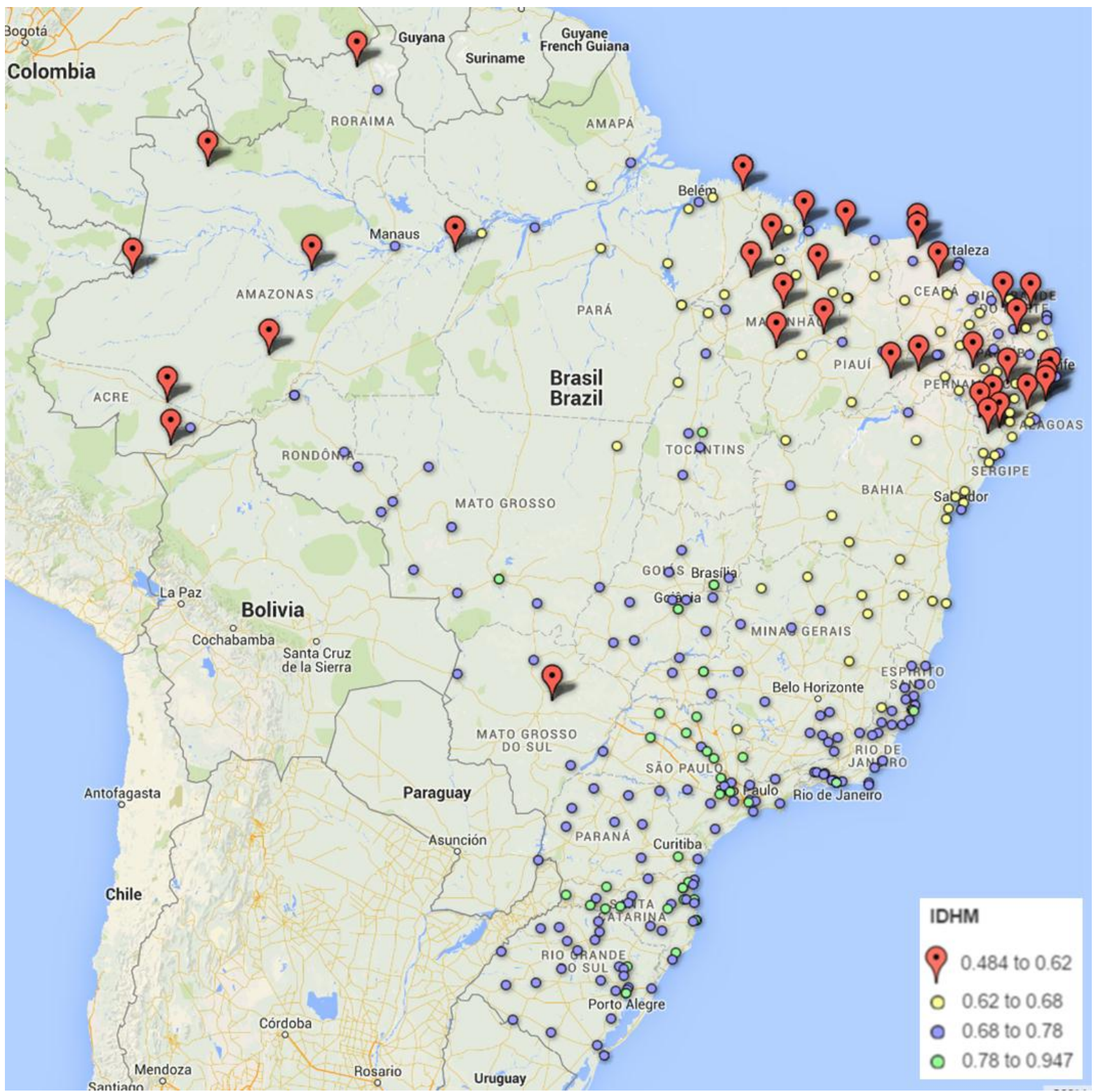

Fonte: Elaboração da autora a partir do cruzamento de dados SISTEC/MEC e IBGE. 
Figura 13-Mapa do IDHM dos municípios onde estavam localizados os Institutos Federais existentes em 2002 (Pré expansão).

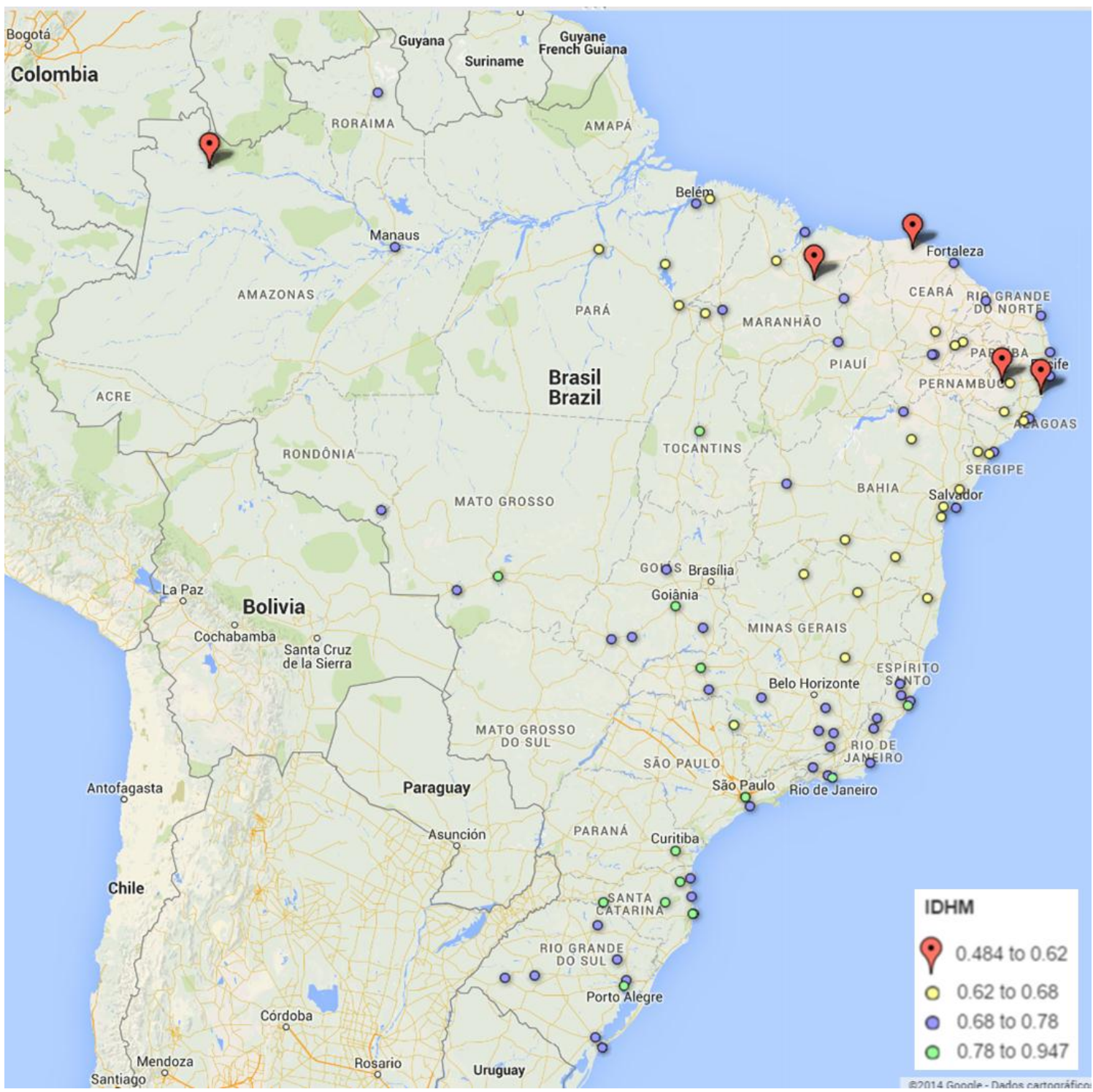

Fonte: Elaboração da autora a partir do cruzamento de dados SISTEC/MEC e IBGE. 
Figura 14-Mapa do IDHM dos municípios onde estavam previstos a implantação de Institutos Federais, durante a 1 ${ }^{a}$. Fase da expansão (2003-2010).

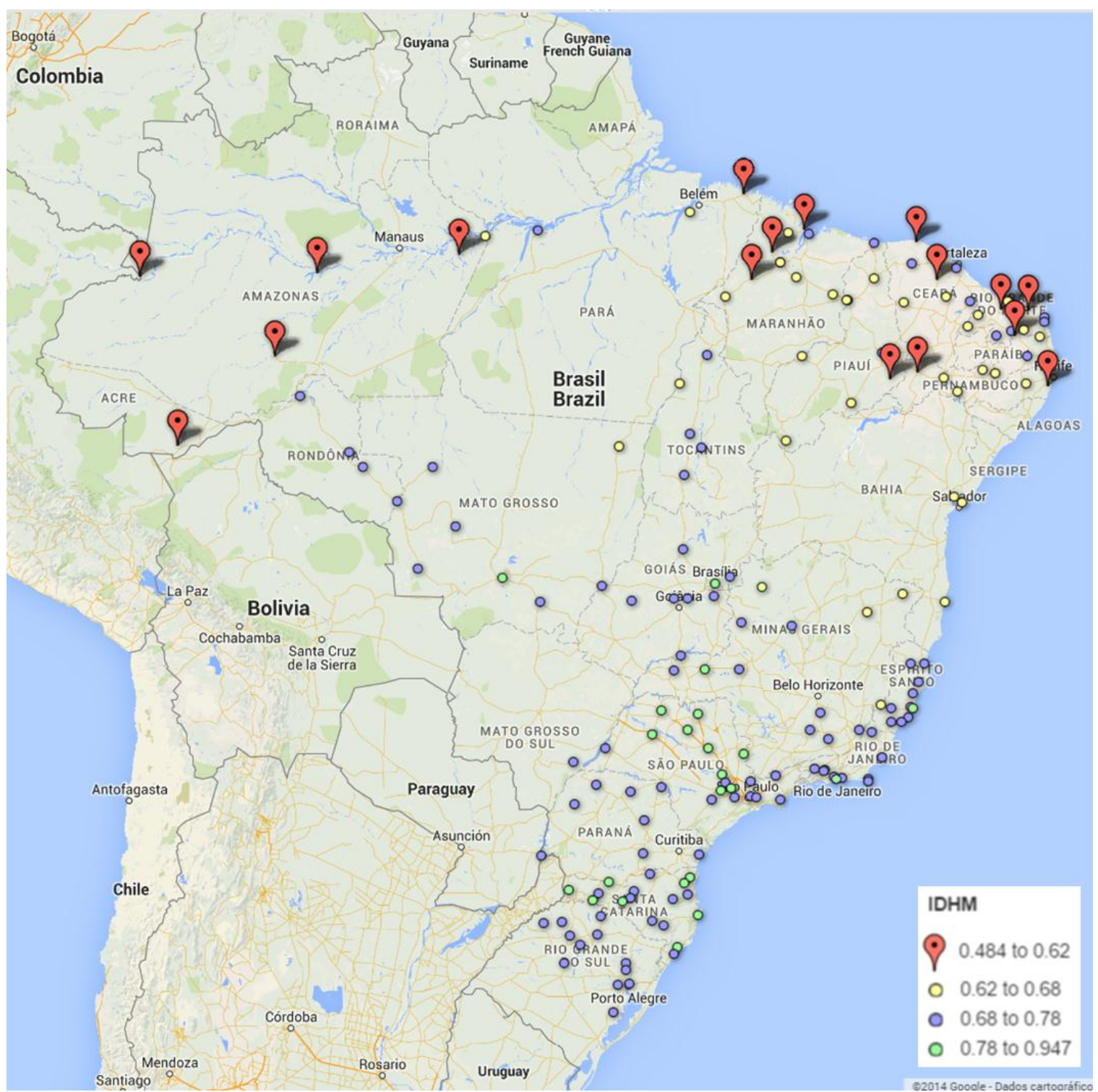

Fonte: Elaboração da autora a partir do cruzamento de dados SISTEC/MEC e IBGE. 
Figura 15-Mapa do IDHM dos municípios onde estavam previstos a implantação de Institutos Federais, durante a 2ª . Fase da expansão (2011-2012).

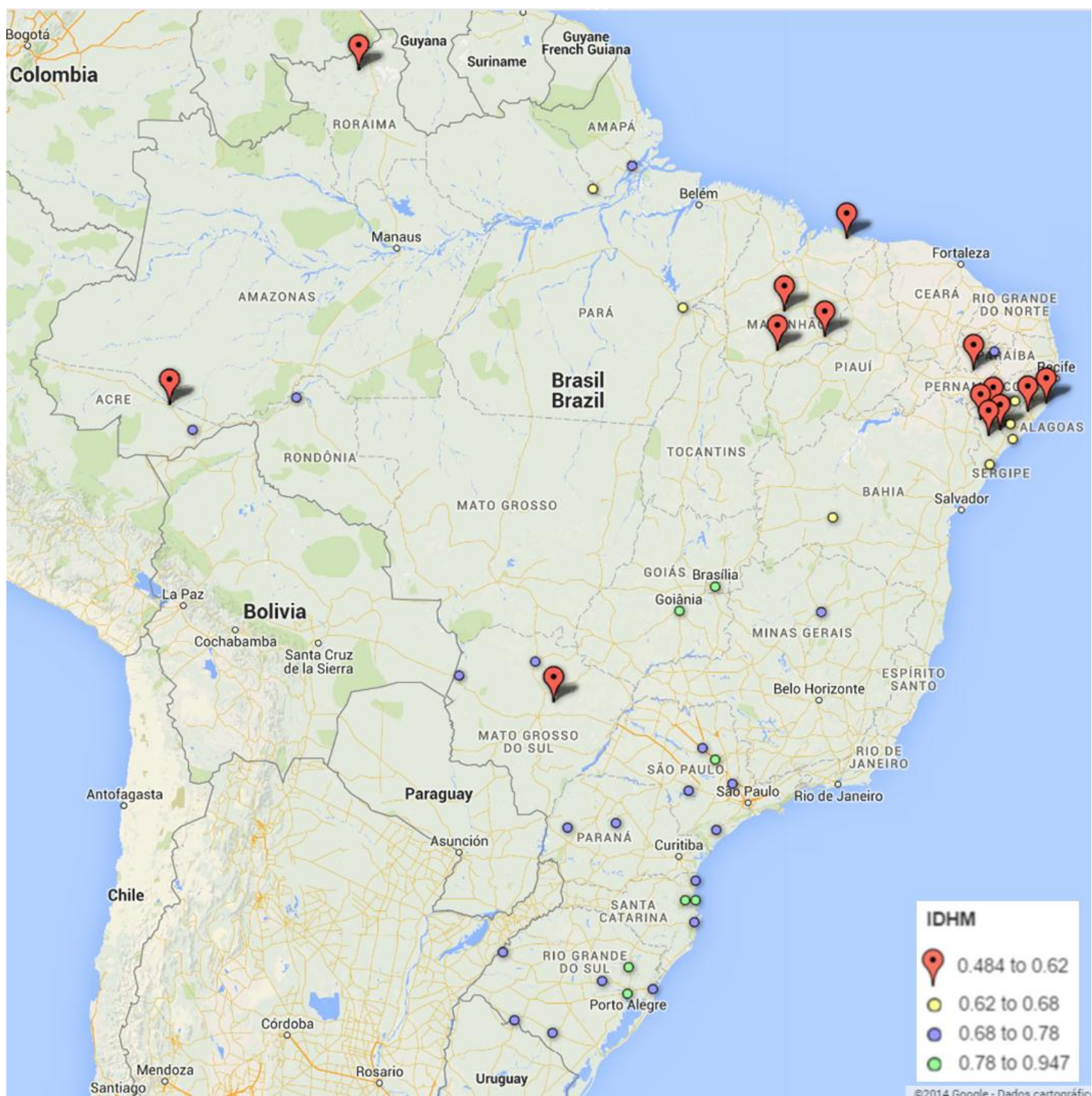

Fonte: Elaboração da autora a partir do cruzamento de dados SISTEC/MEC e IBGE. 


\subsubsection{CATEGORIA DE ANÁLISE: PIB}

O Produto Interno Bruto per capita (ou por pessoa) é a soma das riquezas produzidas dividida em partes iguais pela população. Este indicador mede a atividade econômica e o nível de riqueza de uma região. O Produto Interno Bruto é o principal medidor do crescimento econômico de uma região, seja ela uma cidade, um estado, um país ou mesmo um grupo de nações. Sua medida é feita a partir da soma do valor de todos os serviços e bens produzidos na região escolhida em um período determinado.

A seguir, quatro figuras contendo mapas com os municípios onde estão localizadas as unidades da rede federal de institutos e o seu valor de PIB. No primeiro mapa (Figura 16), estão marcados todas os municípios das unidades da rede federal existentes em 2013. O segundo mapa (Figura 17), apresenta os municípios nos quais haviam unidades da rede federal preexistentes e anteriores a expansão vivenciada a partir de 2003. O terceiro mapa (Figura 18), evidencia a primeira fase da expansão de unidades dos institutos com relação ao PIB, período de 2003 a 2010. E por fim, o quarto mapa desta seção (Figura 19), apresenta, ainda com relação ao PIB, a expansão de unidades ocorrida nos anos de 2011 a 2012.

Da análise dos mapas, percebe-se o dinâmica da expansão, em três pontos:

- interiorizando suas unidades, mesmo em cidades com pouca expressividade no PIB - nas quais, a instalação do instituto tem o potencial de se tornar vetor de desenvolvimento social;

- interiorizando suas unidades, buscando cidades-polo. Cidades do interior distantes das grandes capitais que se destacam dentre os demais núcleos urbanos menores e exercem grande influência em seu entorno. Essas cidades apresentam forte comércio e prestação de serviços para a região e possuem um PIB mediano;

- ocupando com suas unidades cidades de expressividade industrial ou econômica, e consequentemente, possuidoras de PIB elevado, a 
saber: Ipojuca em Pernambuco, Matão em São Paulo e Brasília no Distrito Federal.

Figura 16-Mapa do PIB dos municípios onde estavam localizados os Institutos Federais existentes em 2013.

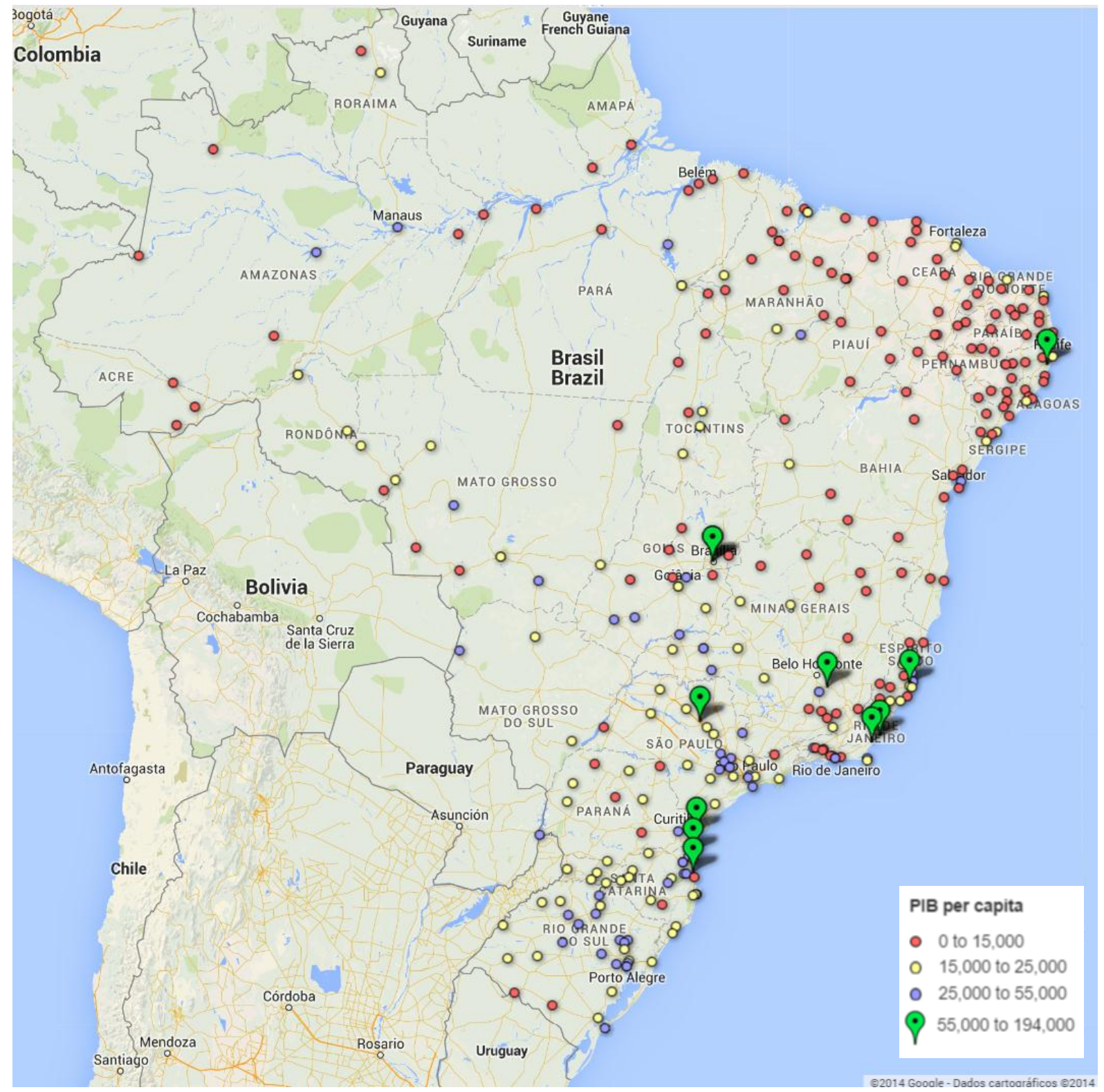

Fonte: Elaboração da autora a partir do cruzamento de dados SISTEC/MEC e IBGE. 
Figura 17-Mapa do PIB dos municípios onde estavam localizados os Institutos Federais existentes em 2002 (Pré expansão).

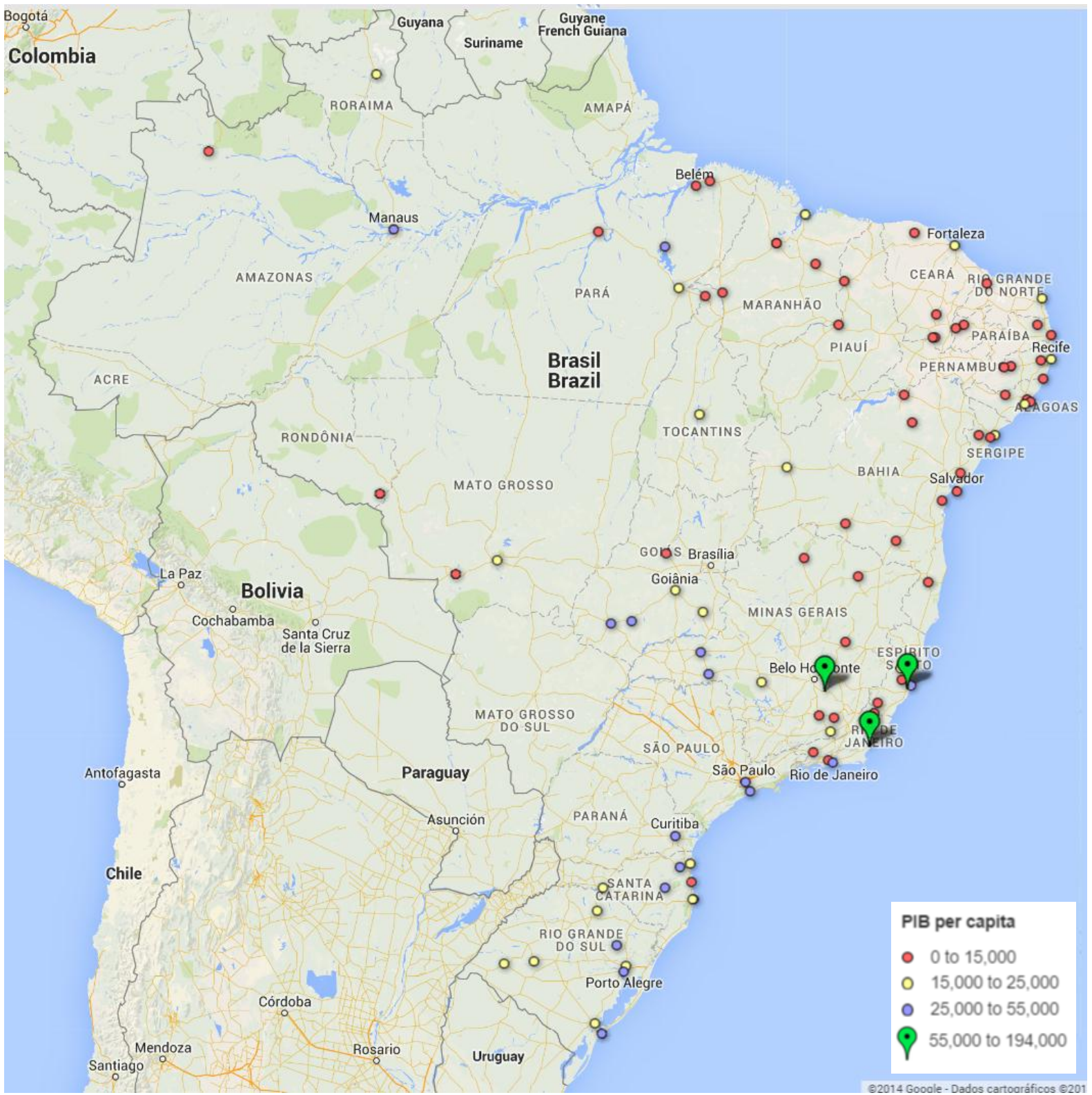

Fonte: Elaboração da autora a partir do cruzamento de dados SISTEC/MEC e IBGE. 
Figura 18-Mapa do PIB dos municípios onde estavam previstos a implantação de Institutos Federais, durante a 1‥ Fase da expansão (2003-2010).

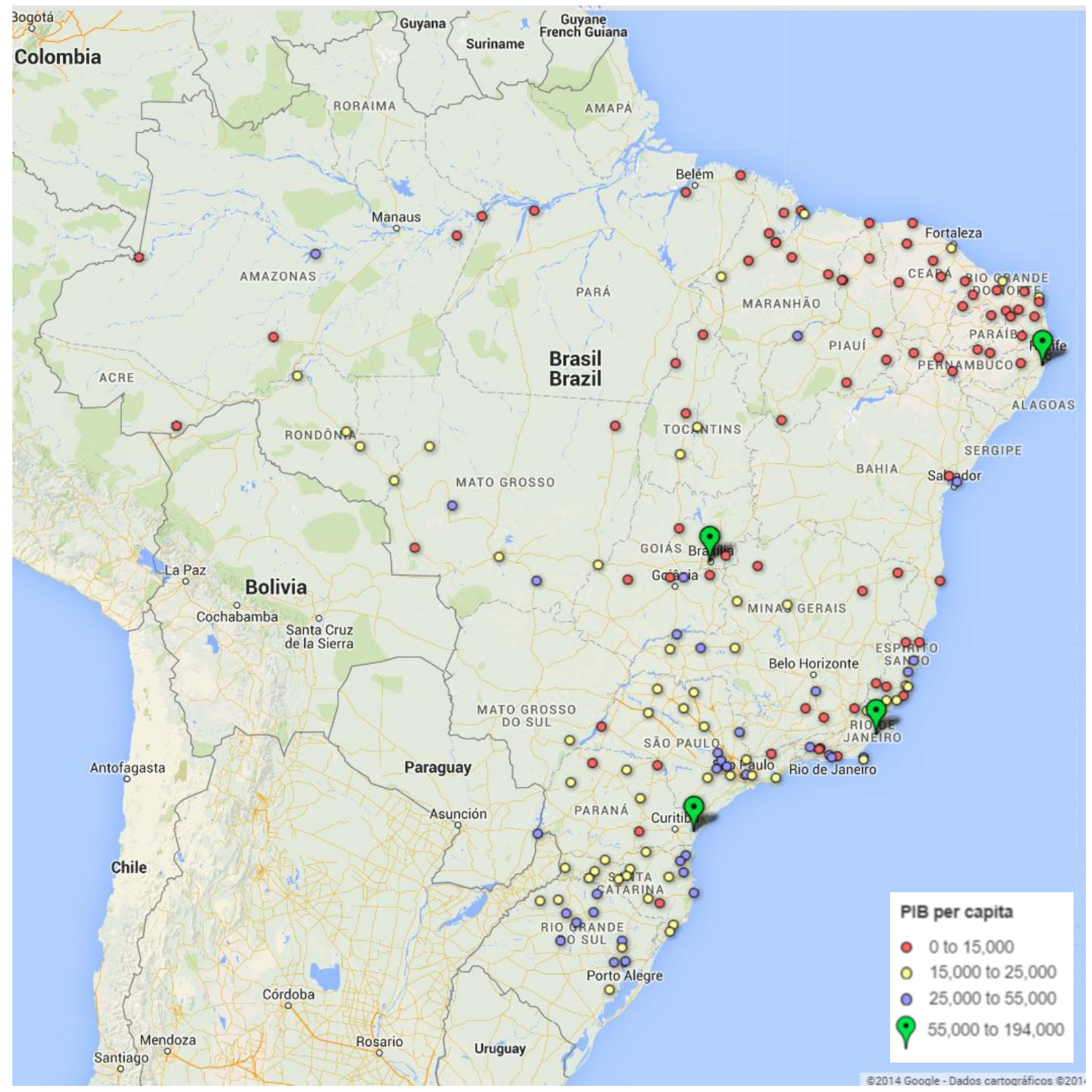

Fonte: Elaboração da autora a partir do cruzamento de dados SISTEC/MEC e IBGE. 
Figura 19-Mapa do PIB dos municípios onde estavam previstos a implantação de Institutos Federais, durante a 2ª ${ }^{\mathrm{a}}$. Fase da expansão (2011-2012).



Fonte: Elaboração da autora a partir do cruzamento de dados SISTEC/MEC e IBGE. 


\title{
6.4.10. CATEGORIA DE ANÁLISE: PIBID
}

O Programa Instituição de Bolsas de Iniciação à Docência (PIBID) é um programa que permite que alunos de licenciatura participantes de projetos de iniciação à docência desenvolvidos por Instituições de Educação Superior (IES) possam ter vivências do ambiente escolar das escolas de educação básica da rede pública de ensino. Este programa objetiva o fomento ao aperfeiçoamento e a valorização da formação de professores para a educação básica.

O programa concede bolsas a alunos de licenciatura participantes destes projetos e promovem a inserção dos estudantes no contexto das escolas públicas desde 0 início da sua formação acadêmica para que desenvolvam atividades didático-pedagógicas sob orientação de um docente da licenciatura e de um professor da escola.

Considerando as novas finalidades dos Institutos Federais, em especial o estímulo a oferta de licenciaturas e:

\begin{abstract}
$V$ - constituir-se em centro de excelência na oferta do ensino de ciências, em geral, e de ciências aplicadas, em particular, estimulando o desenvolvimento de espírito crítico, voltado à investigação empírica $e$

$V I$ - qualificar-se como centro de referência no apoio à oferta do ensino de ciências nas instituições públicas de ensino, oferecendo capacitação técnica e atualização pedagógica aos docentes das redes públicas de ensino; (Brasil, 2008).
\end{abstract}

Este quantitativo de bolsas PIBID ofertadas se constitui num bom indicador de alcance destes objetivos - e articulação dos IFs com a rede pública de ensino - , principalmente feita a proporcionalidade de bolsas com as vagas ofertadas em Licenciatura.

A Figura 20 apresenta as faixas de quantitativo de Bolsas PIBID ofertadas pelos Institutos Federais. Ressalte-se que a maior parte dos institutos oferta acima de 100 bolsas PIBID. 
Figura 20- Mapa de Distribuição de bolsas PIBID nos Institutos Federais, em 2013.

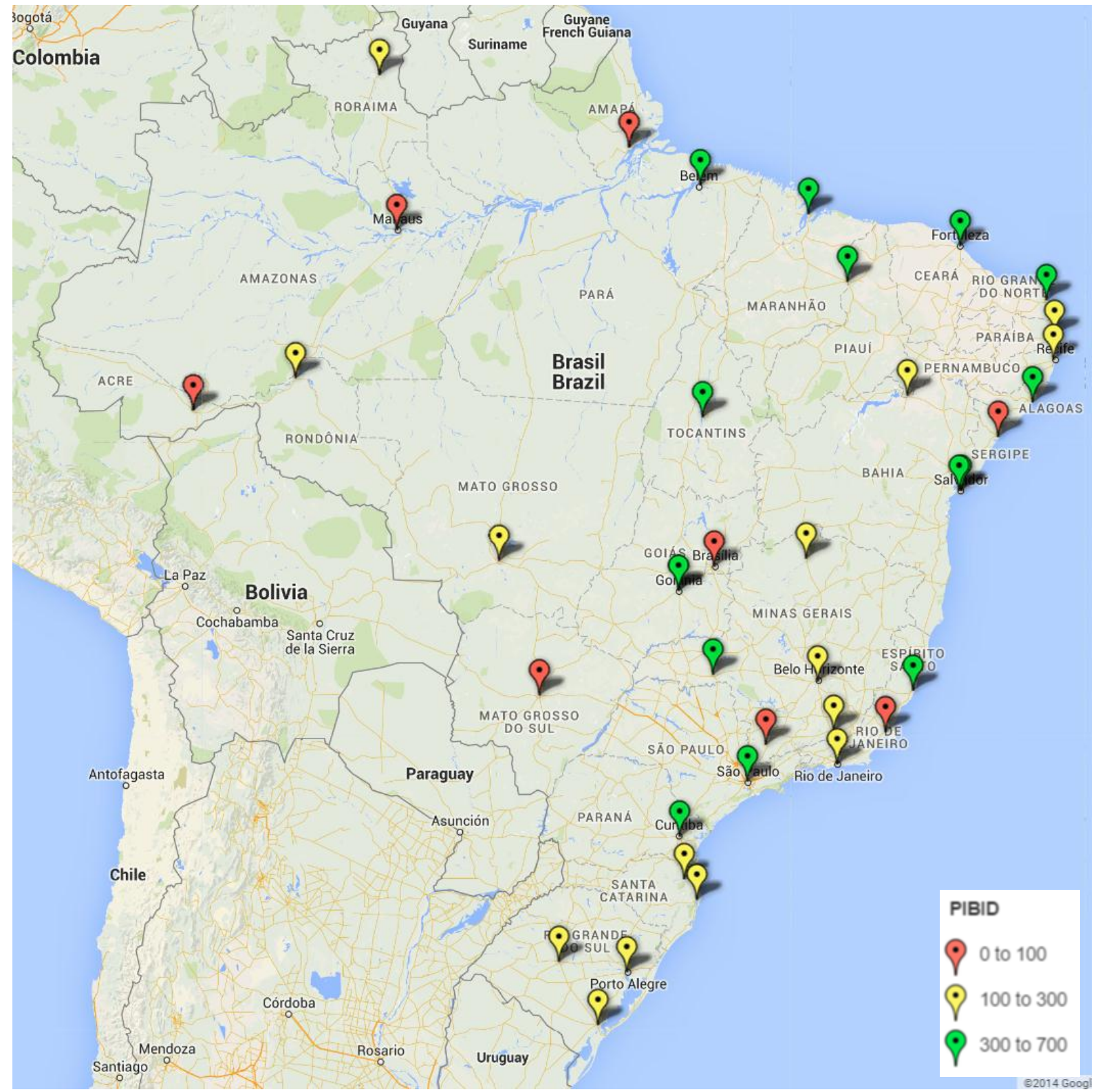

Fonte: Elaboração da autora a partir do cruzamento de dados SISTEC/MEC e CAPES. 


\subsubsection{CATEGORIA DE ANÁLISE: GRUPO DE PESQUISA CNPQ}

Nesta categoria estão listados os Institutos Federais e seus grupos de pesquisa constantes do diretório do Conselho Nacional de Desenvolvimento Científico e Tecnológico - CNPQ.

Um grupo de pesquisa é a denominação atribuída ao grupo de pesquisadores e estudantes que se organizam em torno de uma ou mais linhas de pesquisa de uma área do conhecimento, com o objetivo de desenvolver pesquisa científica. Há o envolvimento profissional e permanente com atividades de pesquisa no qual o trabalho se organiza em torno de linhas comuns de pesquisa e que, em algum grau, compartilha instalações e equipamentos.

Grupos de Pesquisa abrangem linhas de pesquisa definidas no interior de uma área de conhecimento. Usualmente, as atividades de pesquisa na instituição, individuais ou integradas, estão inseridas em grupos de pesquisa previamente cadastrados.

$\mathrm{Na}$ rede federal de institutos, os IF do Rio Grande do Norte, Espírito Santo, Ceará e Santa Catarina, são os que possuem a maior quantidade de grupos de pesquisa. Assim, o quantitativo de grupos de pesquisa na rede federal não acompanha a distribuição do parque industrial brasileiro (a exceção de Santa Catarina), nem tampouco, estão diretamente relacionados com aos grandes centros urbanos onde estão localizados os Institutos. Ao que parece, a expressiva quantidade de grupos de pesquisa nestes Estados deve-se, menos a conjunturas locais e mais ao esforço coletivo de seu grupo de docentes.

O quantitativo de grupo de pesquisa cadastrados na base do CNPQ é um bom indicador do potencial utilizado pelo instituto para pesquisa. Entretanto, este não é um indicador exclusivo de pesquisa nos institutos. Vale ressaltar, de um lado, a existência de atividades de pesquisa não cadastrada nesta base (CNPQ), bem como, no lado oposto, a existência de grupos de pesquisa cadastrados na base sem aparente ação, ou seja, cadastrados porém inativos. 
Alguns pontos são merecedores de atenção, quando dessa análise: qual o tipo de pesquisa o IF faz, de forma mais comum? Como fomentar o número de pesquisa tecnológica? Como ampliar o acesso aos órgãos de fomento? A título de exemplo, do potencial para pesquisa de cunho tecnológico da rede federal, vale citar o caso recente da chamada CNPq-SETEC/MEC № 17/2014, lançada em agosto deste ano e que visa apoiar projetos de pesquisa científica e tecnológica aplicada, de extensão tecnológica, que contribuam significativamente para o desenvolvimento científico e tecnológico do País. Foi divulgado pela imprensa o volume recorde de submissões de 1800 projetos.

Figura 21-Mapa de Distribuição de grupos de pesquisa cadastrados na base CNPQ presentes nos Institutos Federais, em 2013.

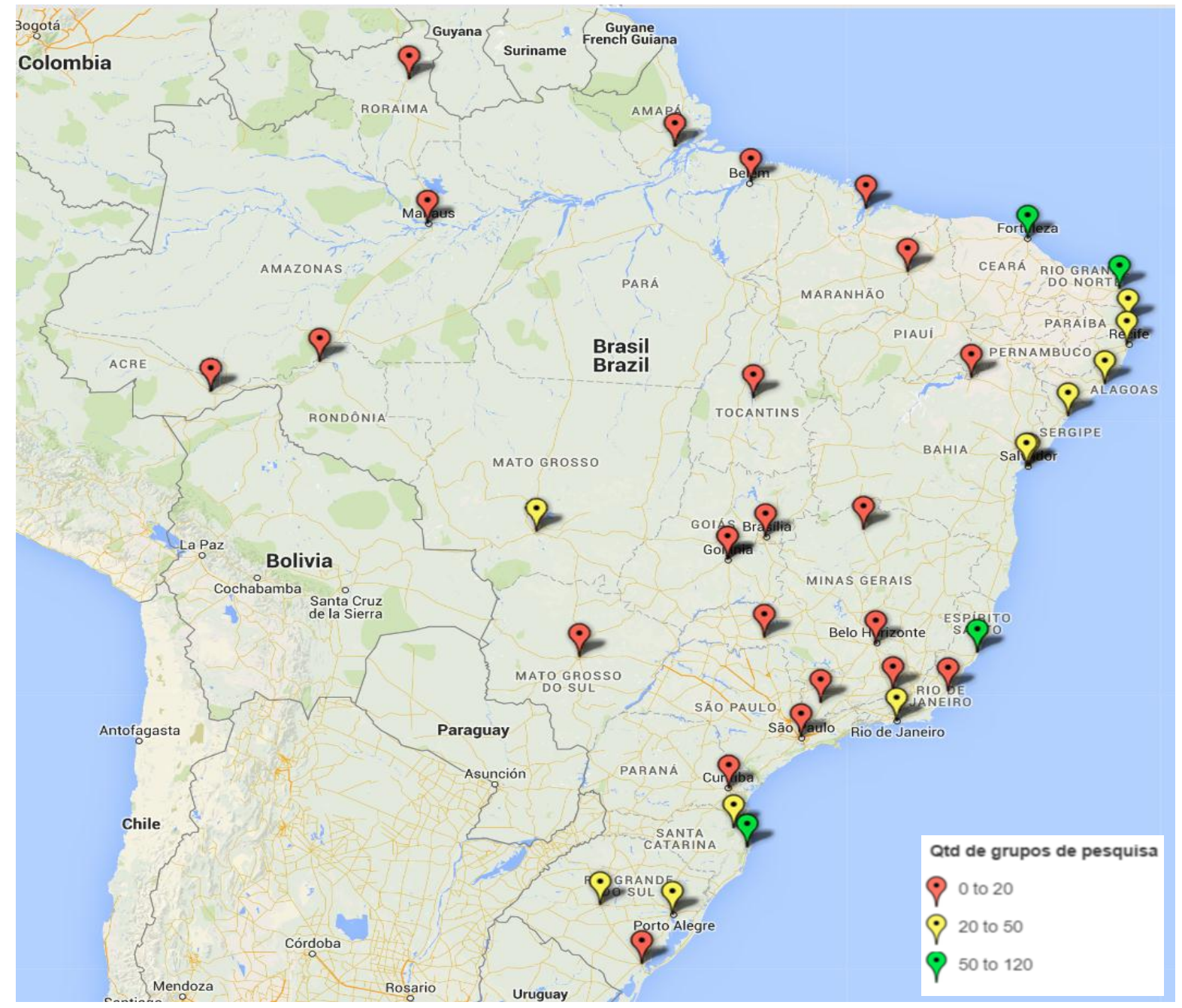

Fonte: Elaboração da autora a partir do cruzamento de dados SISTEC/MEC e CNPQ. 


\subsection{MODELO TEÓRICO DAS FINALIDADES DOS INSTITUTOS FEDERAIS DE EDUCAÇÃO, CIÊNCIA E TECNOLOGIA}

O quarto produto desse trabalho é uma proposta de modelagem teórica das finalidades dos Institutos Federais de Educação Ciência e Tecnologia. A seguir será descrito as etapas desenvolvidas para chegar à definição do modelo das finalidades dos Institutos Federais - produto principal deste estudo - com base no disposto na legislação que os instituiu. A partir do exame detalhado de cada uma das nove finalidades - elencadas no Art $6^{\circ}$ da Lei Federal $n^{\circ} 11.892 / 2008$, o passo seguinte foi identificar o conjunto de variáveis que emergem da legislação, mapeando suas possíveis relações.

Ademais, importa destacar as interfaces e até sobreposições entre as diversas finalidades descritas para esses Institutos, as quais exigem do pesquisador, necessariamente, a aplicação de visão sistêmica e não linear do conjunto das finalidades, conduzindo à identificação de articulações entre elas, assim como entre suas variáveis.

A seguir definem-se os esquemas que representam os elementos constitutivos das finalidades dispostas nos incisos do Art $6^{\circ}$ da ${ }^{\circ}$ da Lei Federal $n^{\circ}$ $11.892 / 2008$, os quais intencionam apontar para o conjunto de variáveis e possíveis relações envolvidas no modelo. Ressalta-se que devem ser entendidos como as etapas do raciocínio desenvolvido que conduziram, metodologicamente, à construção do modelo inicial proposto neste estudo.

Assim, na construção gradativa do modelo, identificam-se as variáveis e suas relações a partir dos elementos constitutivos de cada finalidade. Nos esquemas ilustrativos a seguir, destacam-se evolutivamente - para cada finalidade - essas variáveis e suas relações, ressaltadas em cor diferenciada. Com elas, gradativamente o modelo teórico das finalidades vai sendo definido. 
Inciso I do Art. $6^{\circ}$

"I - ofertar educação profissional e tecnológica, em todos os seus níveis e modalidades, formando e qualificando cidadãos com vistas na atuação profissional nos diversos setores da economia, com ênfase no desenvolvimento socioeconômico local, regional e nacional".

Variáveis e suas relações integrantes da representação gráfica desta finalidade Figura 22:

Figura 22-Representação gráfica das variáveis e suas relações presentes no Inciso I do Art 6ํำ da Lei Federal n 11.892/2008.

Modelo teórico das finalidades dos Institutos Federais de Educação e Tecnologia

Inciso I

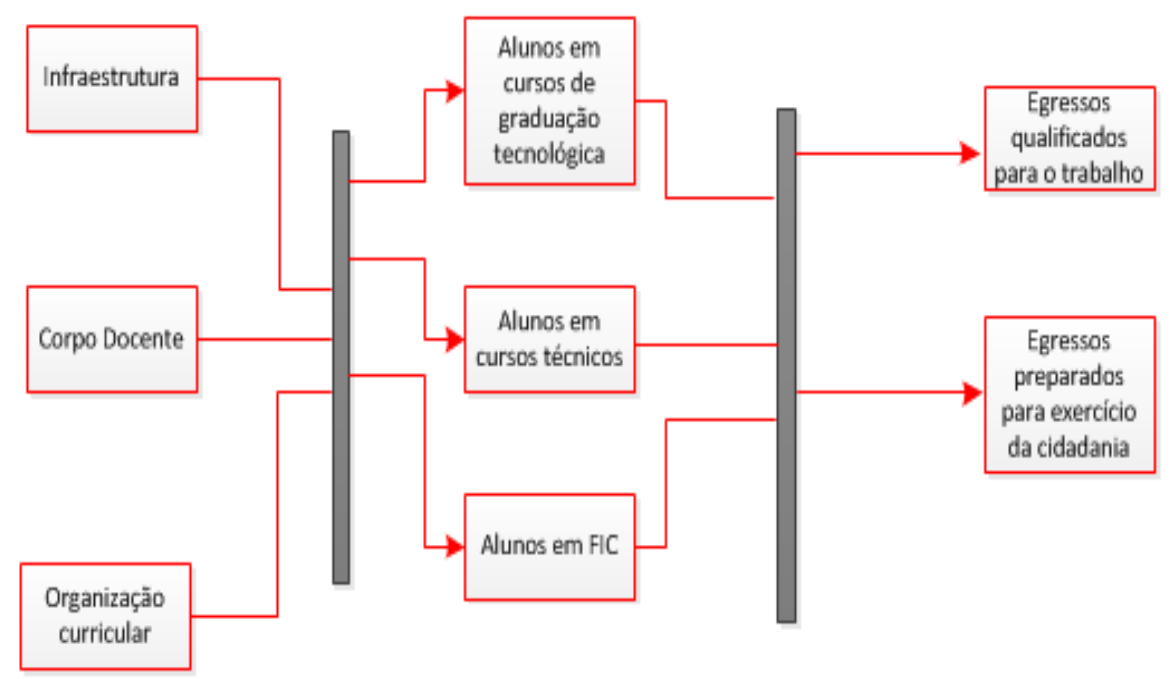

Fonte: Elaboração da autora a partir de revisão da literatura 
Inciso II do Art. $6^{\circ}$

"Il - desenvolver a educação profissional e tecnológica como processo educativo e investigativo de geração e adaptação de soluções técnicas e tecnológicas às demandas sociais e peculiaridades regionais;".

Variáveis e suas relações integrantes da representação gráfica desta finalidade - Figura 23:

Figura 23-Representação gráfica das variáveis e suas relações presentes nos Incisos I e II do Art 6으 da Lei Federal n 11.892/2008.

Modelo teórico das finalidades dos Institutos Federais de Educação e Tecnologia Incisos I e II

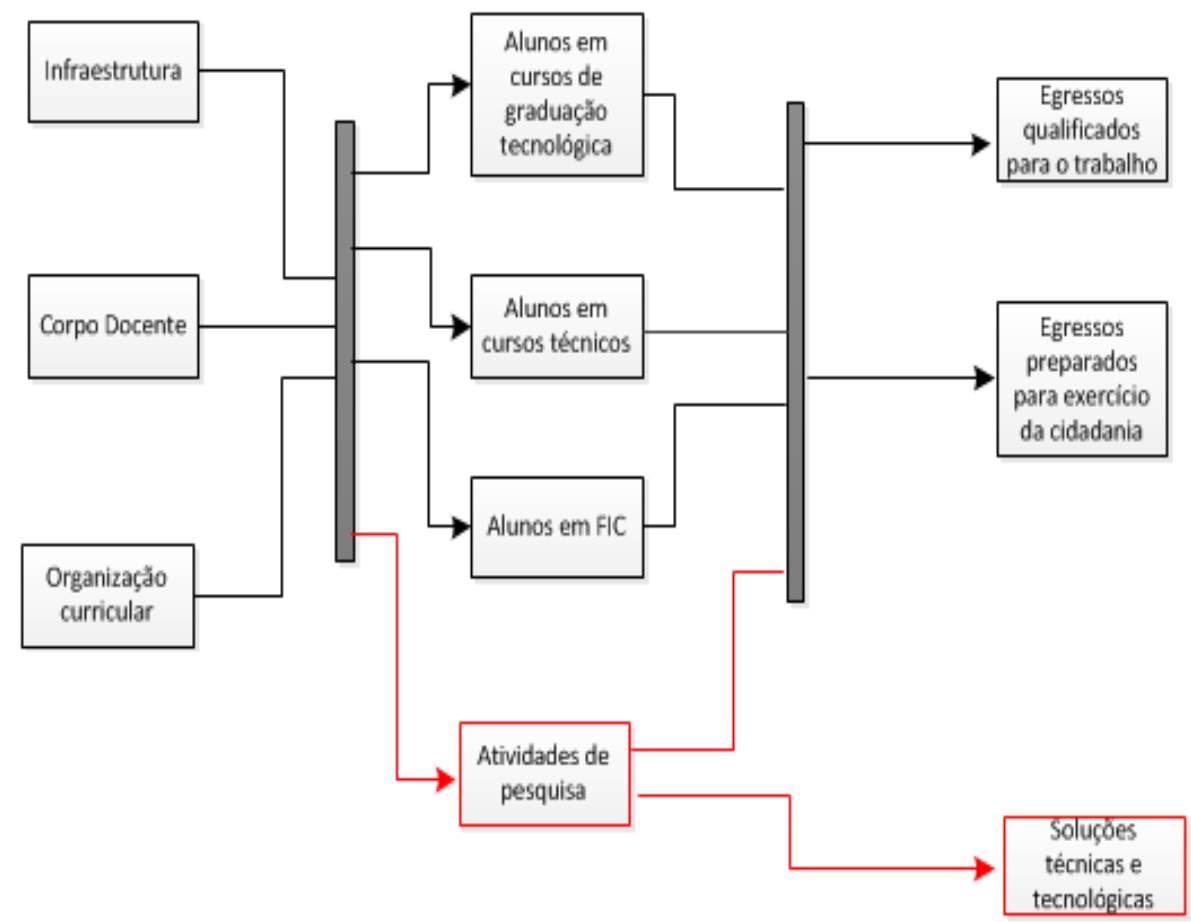

Fonte: Elaboração da autora a partir de revisão da literatura 
Inciso III do Art. $6^{\circ}$

“III - promover a integração e a verticalização da educação básica à educação profissional e educação superior, otimizando a infraestrutura física, os quadros de pessoal e os recursos de gestão;".

Variáveis e suas relações integrantes da representação gráfica desta finalidade - Figura 24:

Figura 24-Representação gráfica das variáveis e suas relações presentes nos Incisos I, II e III do Art 6º da Lei Federal n 11.892/2008.

Modelo teórico das finalidades dos Institutos Federais de Educação e Tecnologia Incisos I, II e III

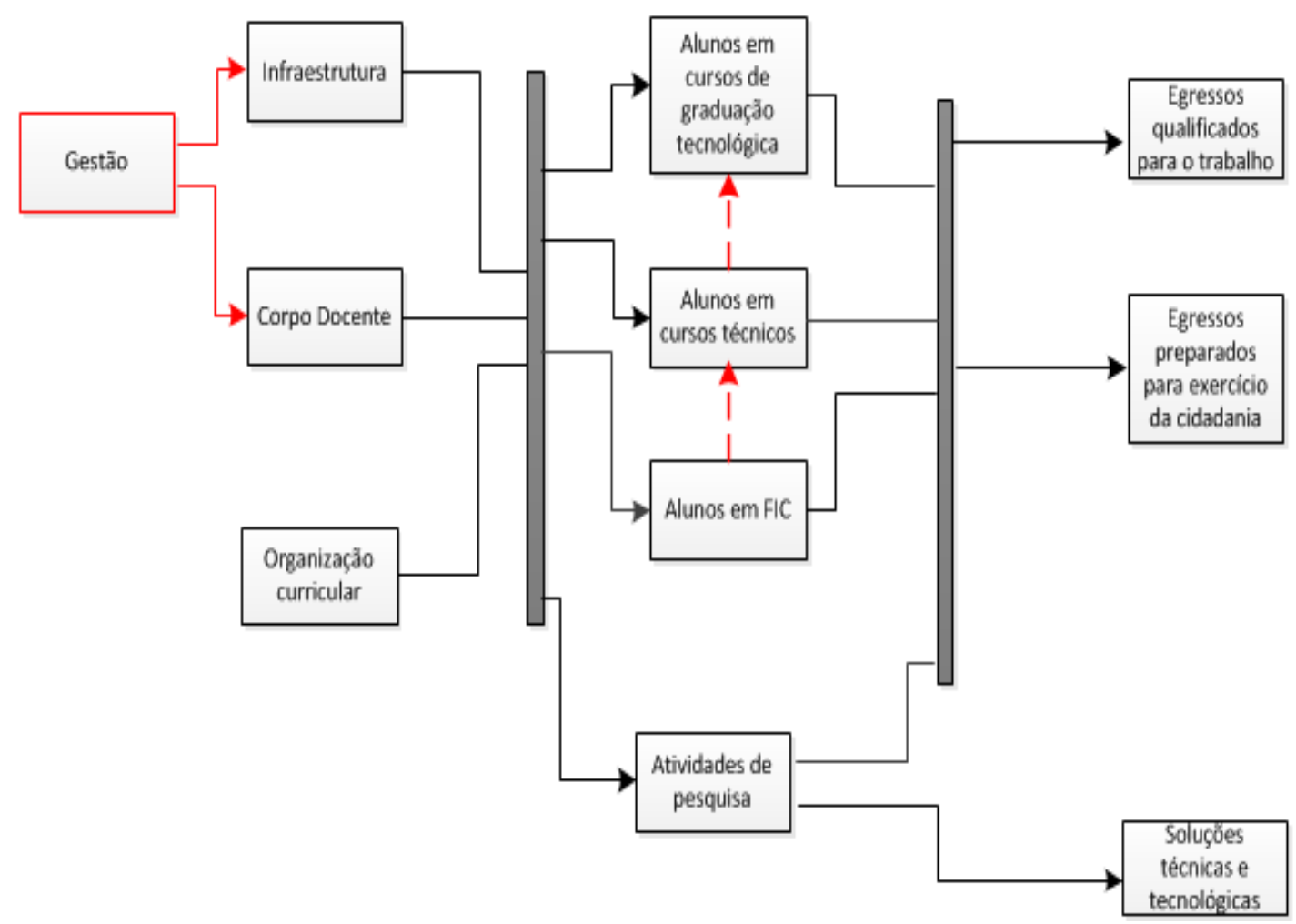

Fonte: Elaboração da autora a partir de revisão da literatura 
Inciso IV do Art. 60

"IV - orientar sua oferta formativa em benefício da consolidação e fortalecimento dos arranjos produtivos, sociais e culturais locais, identificados com base no mapeamento das potencialidades de desenvolvimento socioeconômico e cultural no âmbito de atuação do Instituto Federal;".

Variáveis e suas relações integrantes da representação gráfica desta finalidade - Figura 25:

Figura 25-Representação gráfica das variáveis e suas relações presentes nos Incisos I, II, III e IV do Art 6º da Lei Federal n 11.892/2008.

\begin{tabular}{|c|}
\hline Modelo teórico das finalidades dos Institutos Federais de Educação e Tecnologia \\
Incisos I, II, III e IV
\end{tabular}

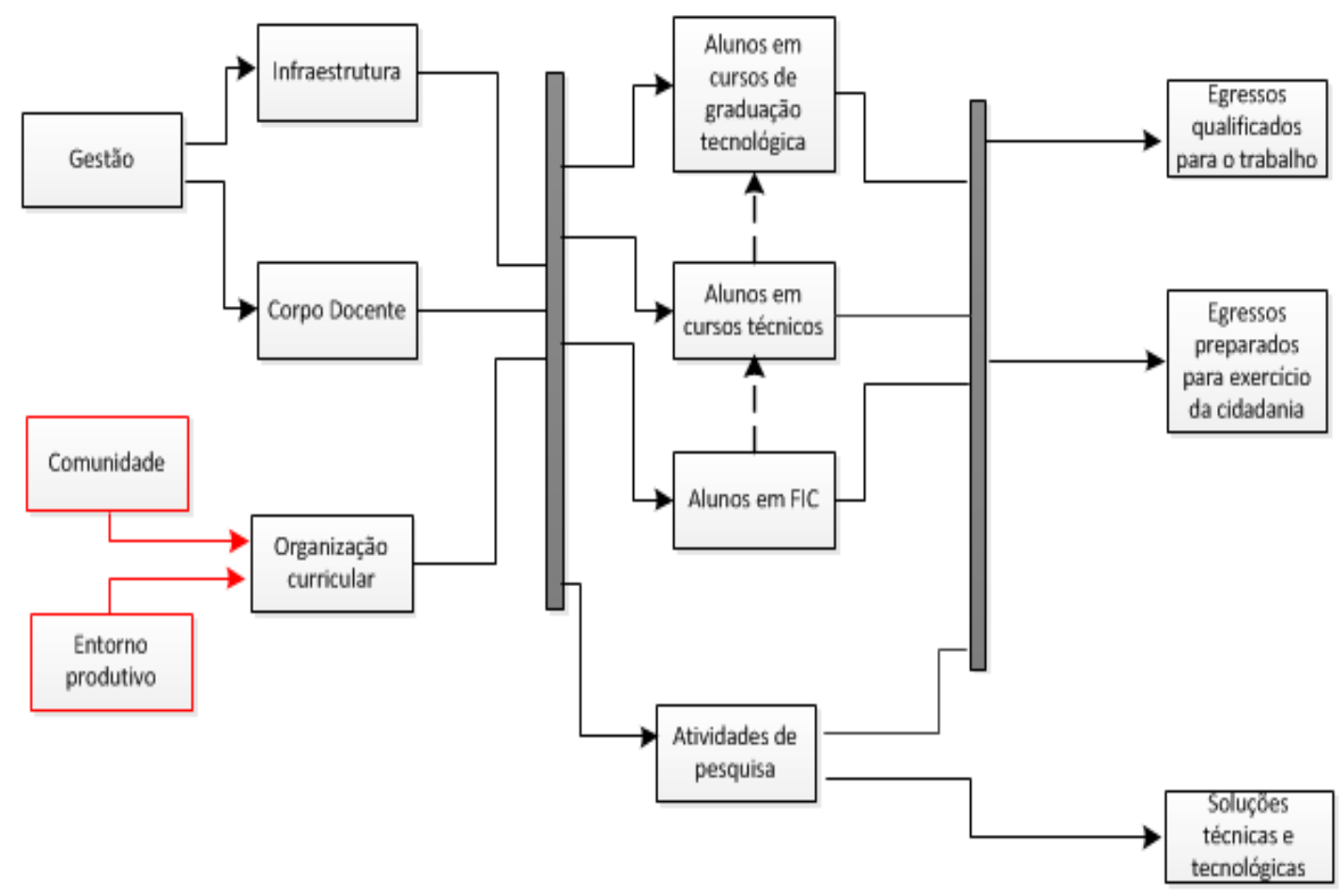

Fonte: Elaboração da autora a partir de revisão da literatura 
Inciso V do Art. 60

"V - constituir-se em centro de excelência na oferta do ensino de ciências, em geral, e de ciências aplicadas, em particular, estimulando o desenvolvimento de espírito crítico, voltado à investigação empírica;".

Variáveis e suas relações integrantes da representação gráfica desta finalidade - Figura 26:

Figura 26-Representação gráfica das variáveis e suas relações presentes nos Incisos I, II, III, IV e V do Art 6o da Lei Federal n 11.892/2008.

Modelo teórico das finalidades dos Institutos Federais de Educação e Tecnologia Incisos I, II, III, IV e V

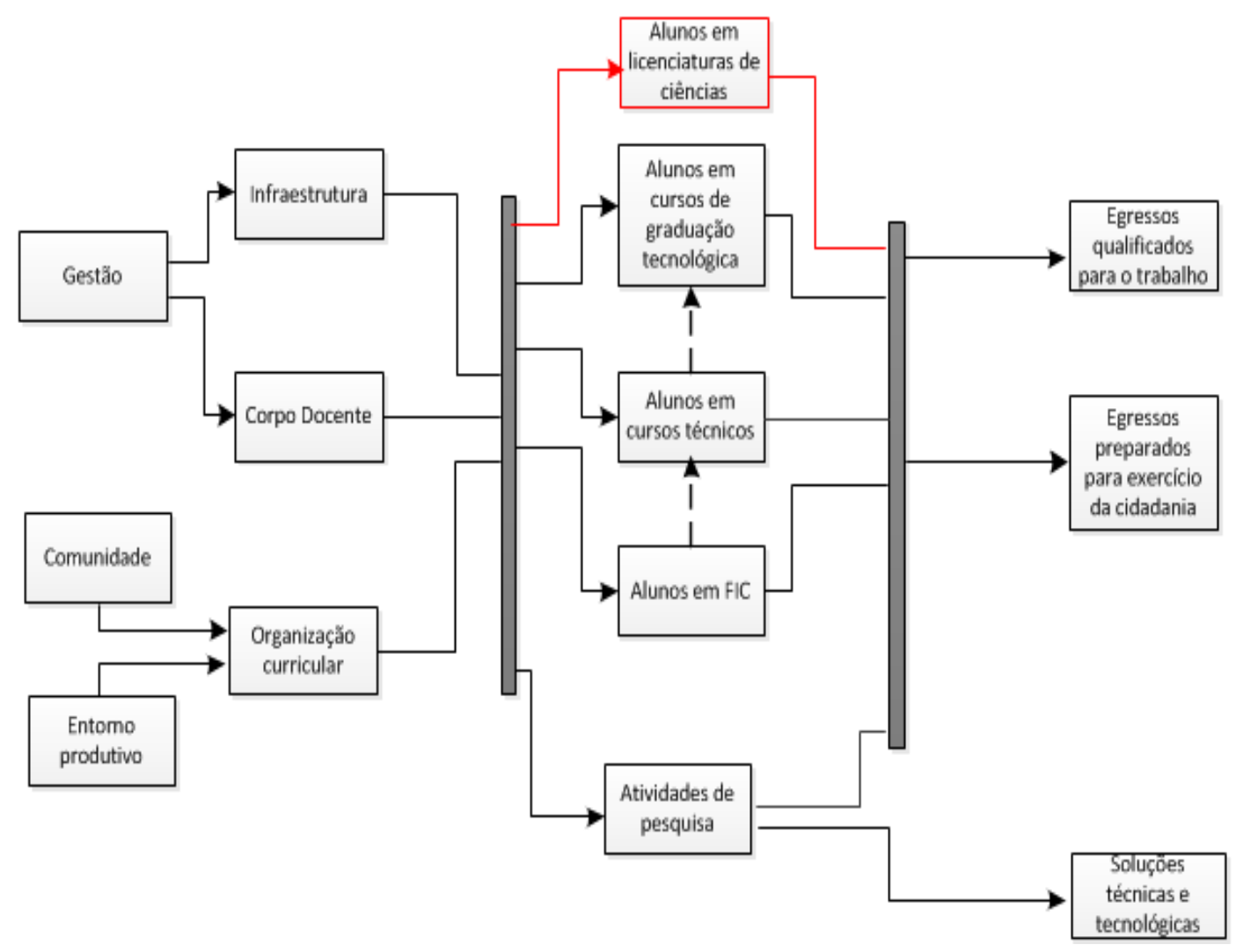

Fonte: Elaboração da autora a partir de revisão da literatura 
Inciso VI do Art. 6o

"VI - qualificar-se como centro de referência no apoio à oferta do ensino de ciências nas instituições públicas de ensino, oferecendo capacitação técnica e atualização pedagógica aos docentes das redes públicas de ensino;".

Variáveis e suas relações integrantes da representação gráfica desta finalidade Figura 27:

Figura 27-Representação gráfica das variáveis e suas relações presentes nos Incisos I, II, III, IV, V e VI do Art 6º da Lei Federal n 11.892/2008.

Modelo teórico das finalidades dos Institutos Federais de Educação e Tecnologia Incisos I, II, III, IV, V e VI

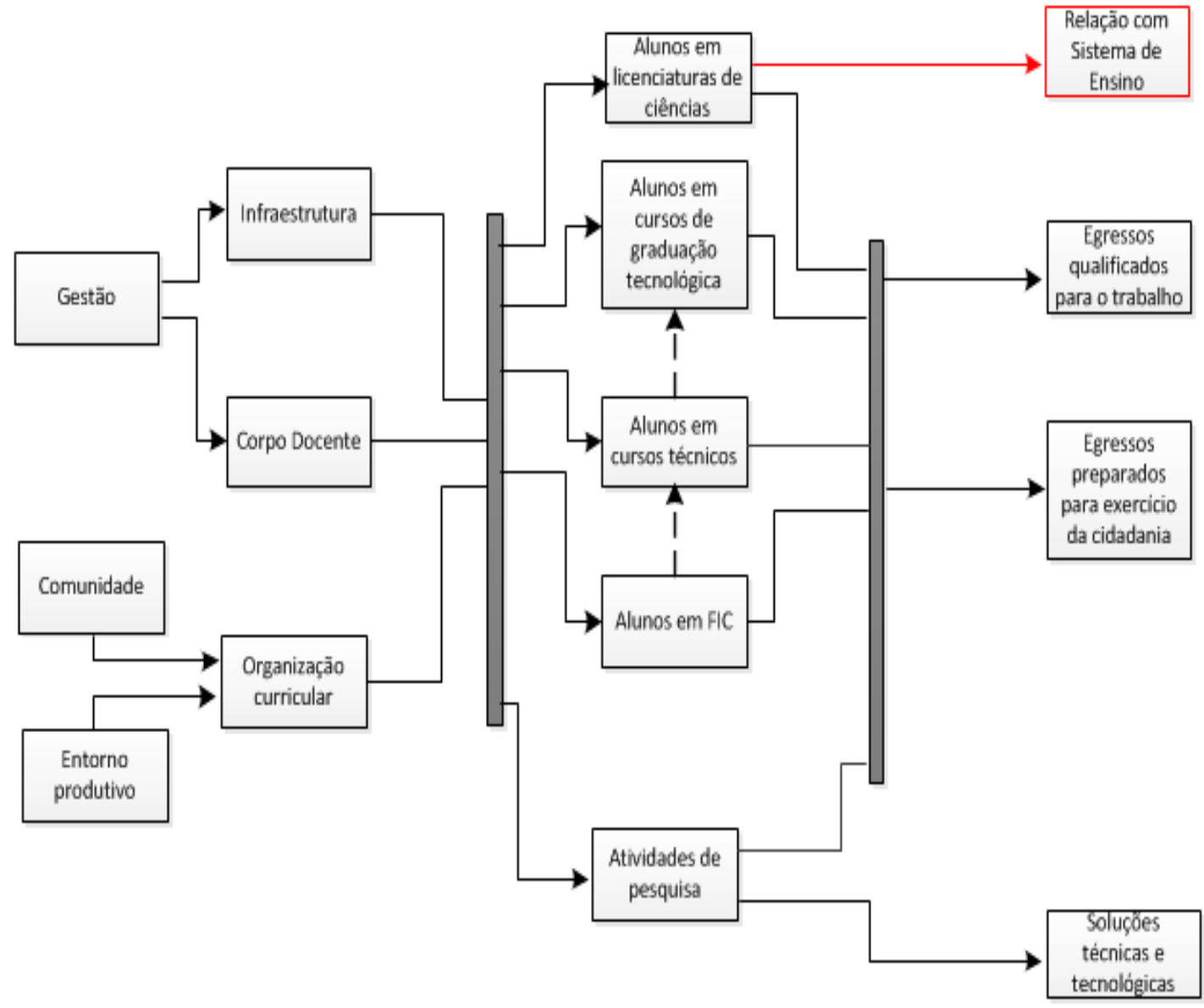

Fonte: Elaboração da autora a partir de revisão da literatura 
Inciso VII do Art. 60

"VII - desenvolver programas de extensão e de divulgação científica e tecnológica;".

Variáveis e suas relações integrantes da representação gráfica desta finalidade - Figura 28:

Figura 28-Representação gráfica das variáveis e suas relações presentes nos Incisos I, II, III, IV, V , VI e VII do Art 6º da Lei Federal n 11.892/2008.

Modelo teórico das finalidades dos Institutos Federais de Educação e Tecnologia Incisos I, II, III, IV, V, VI e VII

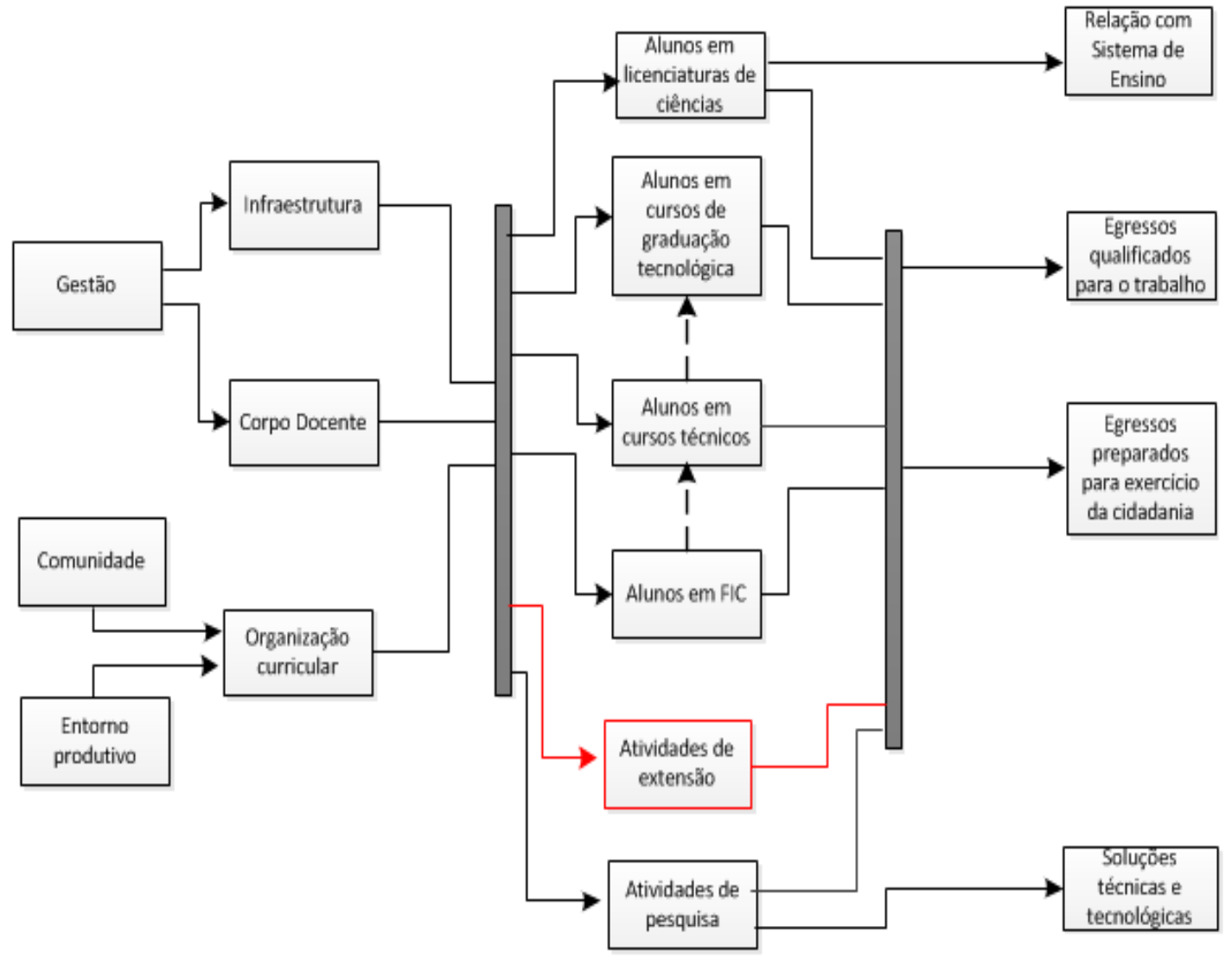

Fonte: Elaboração da autora a partir de revisão da literatura 
Inciso VIII do Art. $6^{\circ}$

"VIII - realizar e estimular a pesquisa aplicada, a produção cultural, o empreendedorismo, o cooperativismo e o desenvolvimento científico e tecnológico;".

Variáveis e suas relações integrantes da representação gráfica desta finalidade - Figura 29:

Figura 29-Representação gráfica das variáveis e suas relações presentes nos Incisos I, II, III, IV, V , VI, VII e VIII do Art 6ํ da Lei Federal n 11.892/2008.

Modelo teórico das finalidades dos Institutos Federais de Educação e Tecnologia Incisos I, II, III, IV, V, VI, VII e VIII

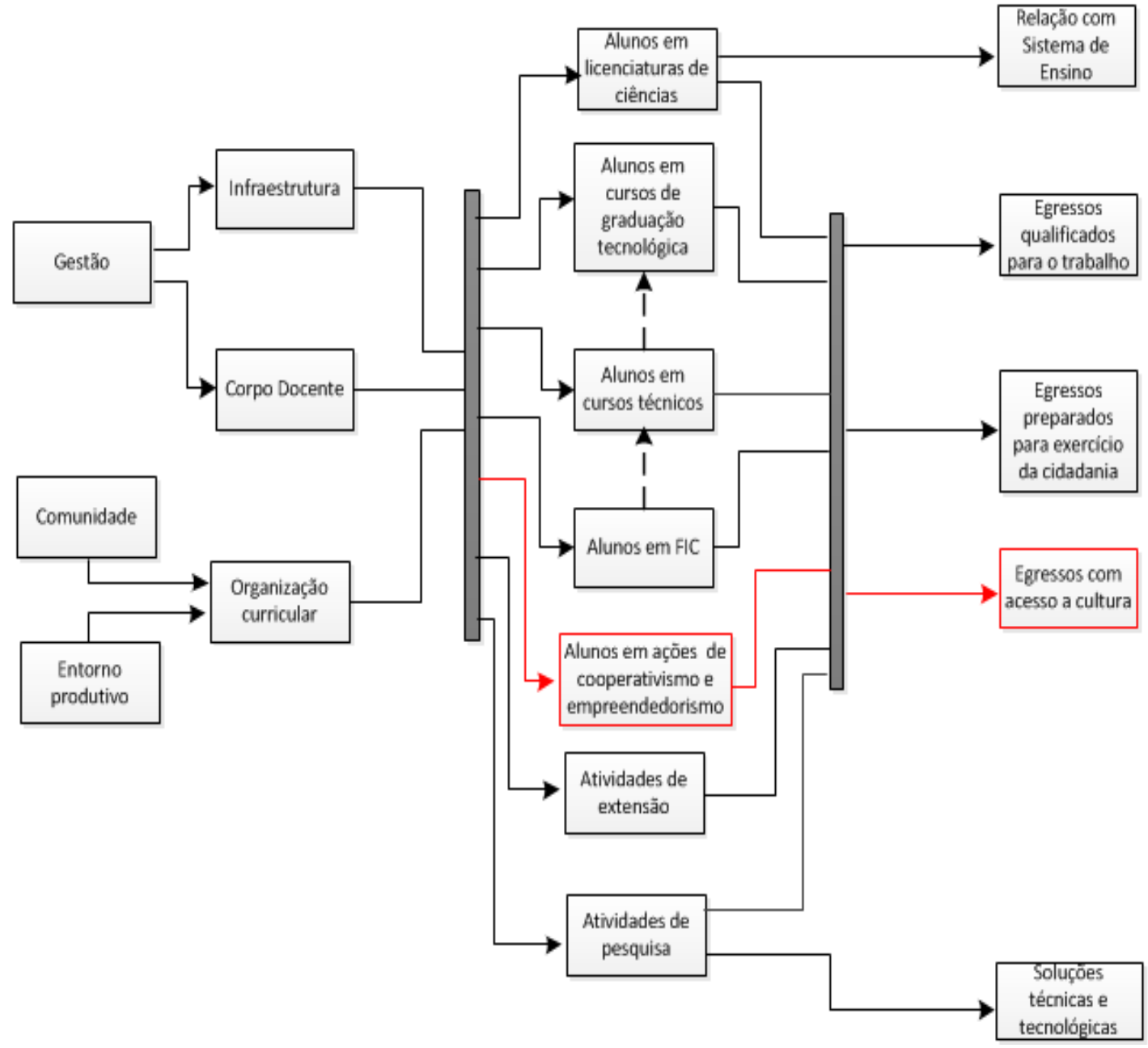

Fonte: Elaboração da autora a partir de revisão da literatura 
Inciso IX do Art. $6^{\circ}$

"IX - promover a produção, o desenvolvimento e a transferência de tecnologias sociais, notadamente as voltadas à preservação do meio ambiente.".

Variáveis e suas relações integrantes da representação gráfica desta finalidade - Figura 30:

Figura 30-Representação gráfica das variáveis e suas relações presentes nos Incisos I, II, III, IV, V , VI, VII ,VIII e IX do Art 6ํ da Lei Federal n 11.892/2008.

Modelo teórico das finalidades dos Institutos Federais de Educação e Tecnologia Incisos I, II, III, IV, V, VI, VII, VIII e IX

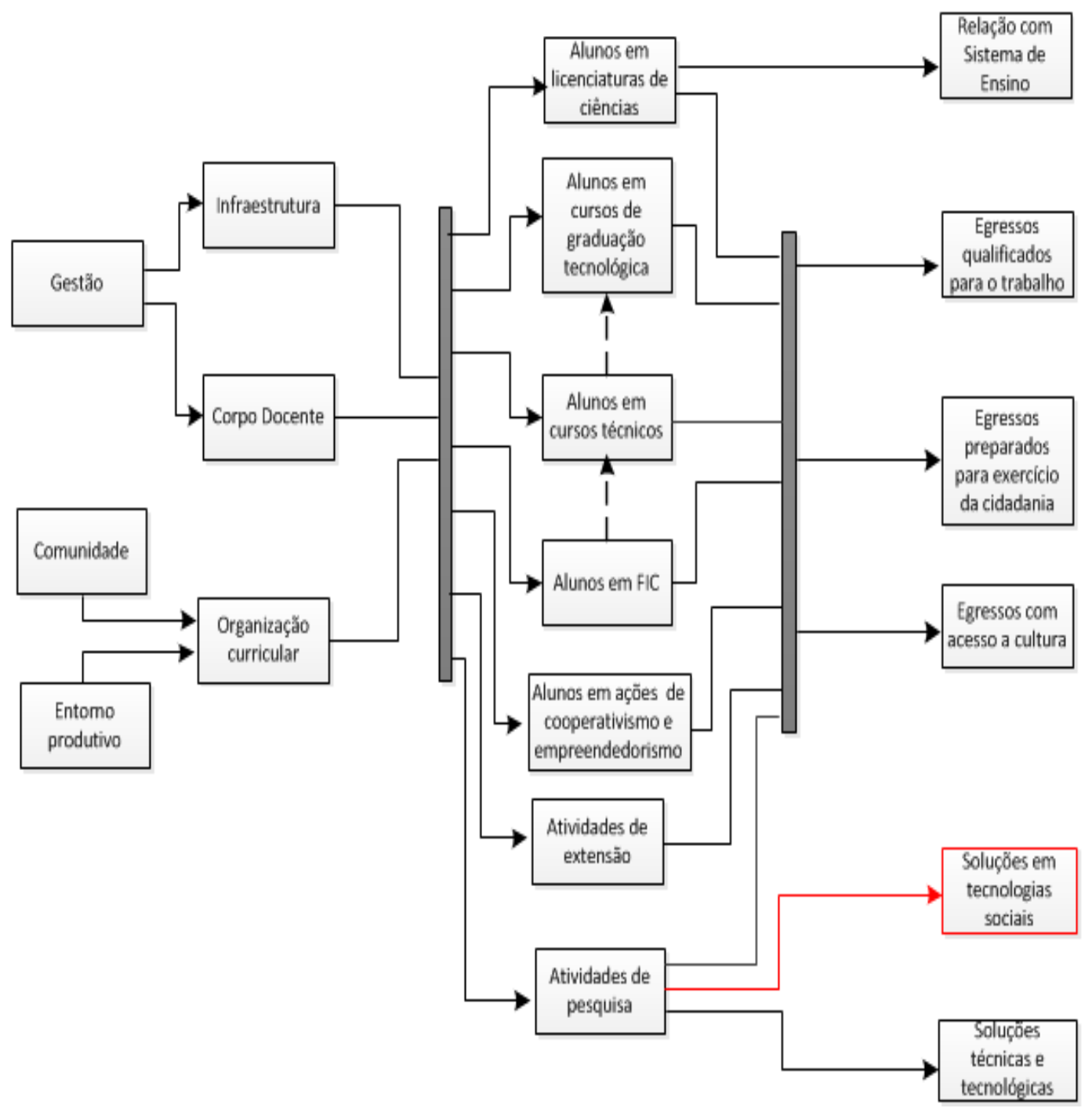

Fonte: Elaboração da autora a partir de revisão da literatura 


\subsubsection{MODELO TEÓRICO DAS FINALIDADES DOS INSTITUTOS FEDERAIS}

Da construção descrita anteriormente nessa seção resulta a proposição do modelo teórico especificado na Figura 31

Figura 31-Representação gráfica das variáveis e suas relações presentes nos Incisos do Art 6º da Lei Federal n 11.892/2008. 
Modelo teórico das finalidades dos Institutos Federais de Educação e Tecnologia Incisos I, II, III, IV, V, VI, VIII, VIII e IX

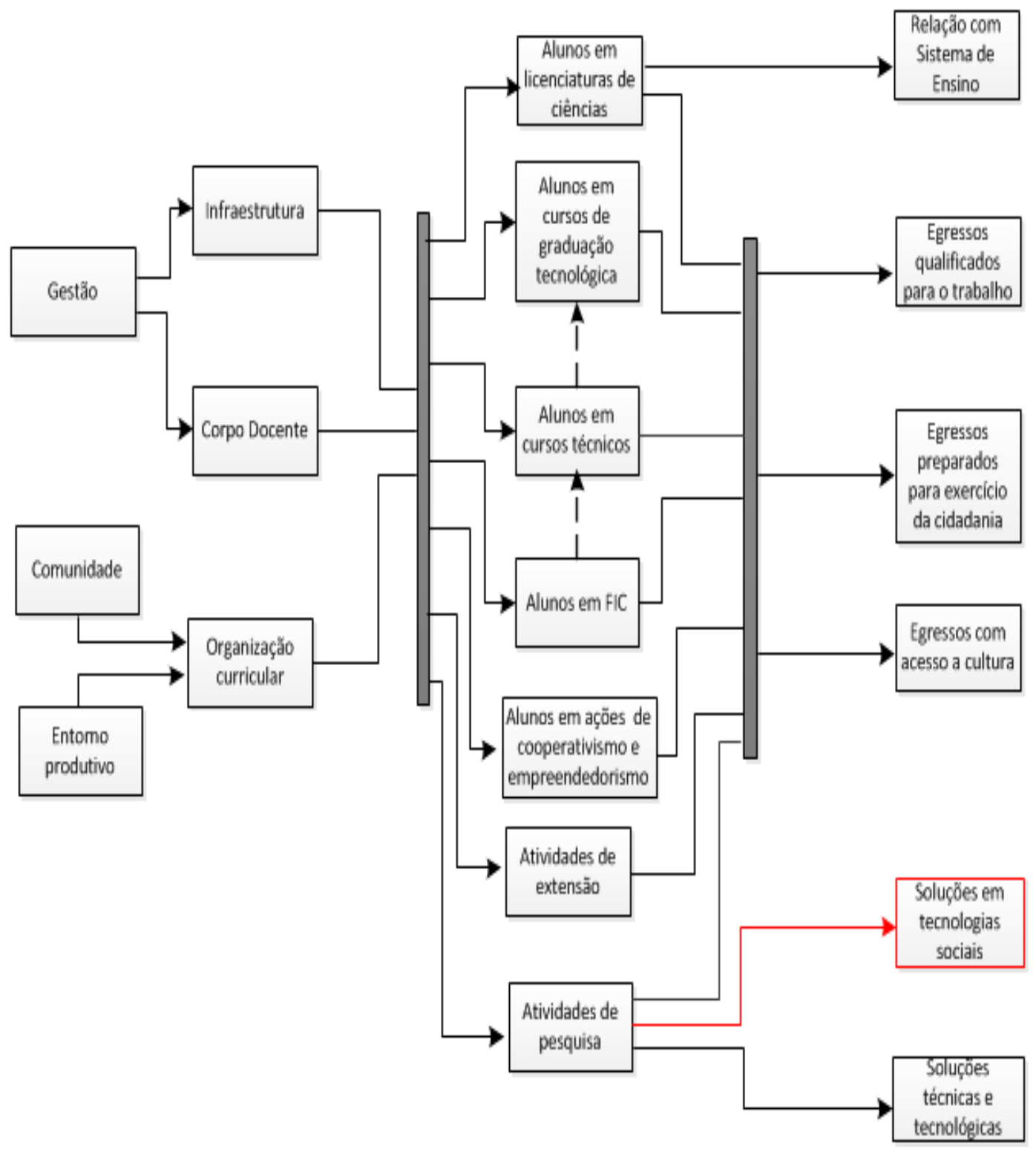

Fonte: Elaboração da autora a partir de revisão da literatura

\subsubsection{VARIÁVEIS E CONSTRUCTOS: DEFINIÇÃO OPERACIONAL}


Da construção descrita anteriormente nessa seção resulta a proposição do modelo teórico especificado na Figura 31

Figura 31 a sua definição constitutiva e definição operacional (vide Anexo I para informações a respeito da definição de variáveis e constructos).

Além das definições constitutivas e operacionais, é apresentado uma proposta de aquisição de dados de forma primária e secundária. A seguir, para os dados advindos de fontes secundárias são apresentadas sua respectiva fonte de dados. Por sua vez, para os dados atualmente não disponíveis - aqueles em que seria necessário a sua obtenção por instrumento de pesquisa primária - é apresentado um conjunto de questões que integrariam este instrumento. Portanto, o conjunto de questões formuladas no escopo desta tese, e apresentado nesta seção, constitui subsídios suficientes para um instrumento de avaliação de egressos voltado para a educação profissional e tecnológica.

\section{Variável: Gestão Escolar}

- Definição constitutiva: Processo político-administrativo contextualizado, por meio do qual a prática social da educação é organizada, orientada e viabilizada. Implica gestão colegiada de recursos materiais e humanos, planejamento de suas atividades, distribuição de funções e atribuições, na relação interpessoal de trabalho e partilha de poder (BORDIGNON, 2004, p. 147).

- Definição operacional: Quantitativo e capacitação de servidores técnico-administrativos.

- Dados primários: proposta de questões a serem aplicadas em instrumento de avaliação de egressos 
- Existem servidores em quantidade suficiente para fornecer apoio administrativo aos professores e gestores do campus?

Resposta em escala de 5 níveis

- Os servidores de apoio administrativo do campus estão bem preparados para exercer suas funções?

Resposta em escala de 5 níveis

2. Variável: Comunidade

- Definição constitutiva: As comunidades são construídas a partir dos interesses e anseios de seus membros, o que faz delas fontes específicas de identidades. Em todas elas existem processos de identidade, objetivos e interesses em comum, a participação em prol deste objetivo, o sentimento de pertença, oriundo da identidade em questão. Portanto, a inserção social do indivíduo, a sua rede de relações, a sua atividade social em geral, são fatores chave na aquisição de novos atributos na qualificação contínua. Incorpora-se ao conceito de comunidade todos os aspectos das mesorregiões em que se situam: os físico-territoriais, os étnico-culturais, os socioeconômicos e os político-institucionais (FIDALGO E MACHADO , 2000, p.340).

- Definição operacional: Escolaridade parental; Cotas em políticas afirmativas; Origem escolar; Dados demográficos censitários do município.

- Dados primários: proposta de questões a serem aplicadas em instrumento de avaliação de egressos

- Qual o nível de escolaridade do seu Pai?

Resposta em níveis

- $\quad$ Qual o nível de escolaridade de sua mãe?

Resposta em níveis 
- Que tipo de curso de ensino médio você concluiu? Resposta em níveis.

- Seu ingresso no curso se deu por meio de políticas de ação afirmativa?

Não;

Sim, por critério étnico-racial (negros, pardos e indígenas);

Sim, por critério de renda;

Sim, por ter estudado em escola pública;

Sim, por sistema diferente dos anteriores.

- Qual o tipo de escola frequentou antes deste curso?

Somente em escola pública;

Somente em escola particular;

Maior parte em escola pública;

Maior parte em escola particular.

- Dados secundários/ Fonte de dados: IDHM/Censo IBGE e IDEB/INEP

3. Variável: Entorno Produtivo

- Definição constitutiva: Entorno produtivo diz respeito a regiões, espaços ou localidades onde empresas se estabelecem, organizam-se, cooperam e concorrem, contribuindo para o desenvolvimento regional e para a definição da vocação daquela região (FIDALGO $\mathrm{E}$ MACHADO, 2000, p.307).

- Definição operacional: Dados econômicos censitários do município; Estágio.

- Dados primários: proposta de questões a serem aplicadas em instrumento de avaliação de egressos

- $\quad$ Com relação a estágio, durante o seu curso de graduação: 
Não fiz nenhum tipo de estágio;

Fiz ou faço somente estágio obrigatório;

Fiz ou faço somente estágio não obrigatório.

- Dados secundários/Fonte de dados: PIB/IBGE e número de empresas no município/IBGE

4. Variável: Infraestrutura

- Definição constitutiva: Infraestrutura escolar é um sistema de serviços que visam sustentar as atividades finalística (ensino, pesquisa e extensão) das escolas. Tais serviços incluem a aquisição, a manutenção e o controle de bens patrimoniáveis, serviços de edificação e conservação de instalações como salas de aula, bibliotecas, laboratórios, auditórios, etc, serviços de telecomunicações e redes de dados, entre outros.

- Definição operacional: quantidade e adequação de laboratórios, condições gerais de salas de aula, biblioteca e espaço de convivência. Acesso à internet.

- Dados primários: proposta de questões a serem aplicadas em instrumento de avaliação de egressos

- Os Laboratórios que utilizo no campus estão devidamente equipados para aulas?

Resposta em escala de 5 níveis

- Há técnicos trabalhando nos laboratórios do campus em quantidade suficiente para que as aulas em laboratório aconteçam normalmente?

Resposta em escala de 5 níveis 


\section{Corpo Docente}

- Definição constitutiva: É o conjunto de professores, pertencentes a determinada escola, que conduzem atividades de ensino, pesquisa e/ou extensão, com qualquer vínculo de emprego: contratação temporária ou concurso público - ou regime de dedicação, exclusiva ou não, às atividades docentes.

- Definição operacional: Regime de trabalho e titulação.

- Dados secundários/ Fonte de dados: Censo INEP.

6. Organização curricular

- Definição constitutiva: O termo currículo é derivado da expressão latina curriculum significando "pista ou circuito atlético". No campo pedagógico, inicialmente significava um elenco de disciplinas e conteúdos. Atualmente, passa a ser entendido como todas as experiências e conhecimentos proporcionados aos estudantes no cotidiano escolar, através do currículo explicito, quanto do currículo oculto.

- Definição operacional: conhecimento teórico e prático do currículo; atualização curricular.

- Dados primários: proposta de questões a serem aplicadas em instrumento de avaliação de egressos

- Como você avalia os conhecimentos práticos da sua área de formação técnica?

Resposta em escala de 5 níveis 
- Como você avalia o currículo do seu curso em relação à sua atualização curricular?

Resposta em escala de 5 níveis

- Você considera que seu curso contribui para a aquisição de formação teórica na área?

Resposta em escala de 5 níveis

7. Alunos em licenciaturas de ciências

- Definição constitutiva: Discentes regulamente matriculados nos cursos de graduação em licenciatura nos Institutos Federais.

- Definição operacional: Quantitativo de discentes em cursos em Licenciatura

- Dados secundários/ Fonte de dados: SISTEC/MEC ou alternativamente Censo INEP.

8. Alunos em cursos de graduação tecnológica

- Definição constitutiva: Discentes regulamente matriculados nos cursos de graduação tecnológica nos Institutos Federais em cada um dos eixos tecnológicos.

- Definição operacional: Quantitativo de discentes em cursos de graduação tecnológica.

- Dados secundários/ Fonte de dados: SISTEC/MEC ou alternativamente Censo INEP. 
9. Alunos em cursos técnicos

- Definição constitutiva: Discentes regulamente matriculados nos cursos técnicos de nível médio nos Institutos Federais em cada um dos eixos tecnológicos.

- Definição operacional: Quantitativo de discentes

- Dados secundários/ Fonte de dados: SISTEC/MEC ou alternativamente Censo INEP.

10. Alunos em FIC

- Definição constitutiva: Discentes regulamente matriculados nos cursos de formação inicial e continuada nos Institutos Federais

- Definição operacional: Quantitativo de discentes

- Dados secundários/ Fonte de dados: SISTEC/MEC.

11. Alunos em ações de cooperativismo e empreendedorismo

- Definição constitutiva: discentes participantes de ações de cooperativismo e empreendedorismo nos Institutos Federais. Comumente se destacam três formas de gestão cooperativa: a cooperativa de produção, a cooperativa de comercialização e a cooperativa de crédito. Conquanto o termo empreendedorismo se referem às condições de inserção e permanência do sujeito no mercado de trabalho e ainda as estratégias de valorização e negociação de sua capacidade de trabalho de forma empreendedora. 
- Definição operacional: Empresas júniores, incubadoras ou cooperativas.

- Dados primários: proposta de questões a serem aplicadas em instrumento de avaliação de egressos

- Há em seu Instituto Federal Incubadora de Empresas?

- Há em seu Instituto Federal Empresas Júnior?

- Você considera que aprendeu em seu curso noções de empreendedorismo e cooperativismos?

Resposta em escala de 5 níveis

12. Atividades de extensão

- Definição constitutiva: Uma das funções sociais da Universidade, realizada por meio de um conjunto de ações dirigidas à sociedade, as quais devem estar indissociavelmente vinculadas ao Ensino e à Pesquisa. Num âmbito geral, sua finalidade é a promoção e o desenvolvimento do bem-estar físico, espiritual e social, a promoção e a garantia dos valores democráticos de igualdade de direitos e de participação, o respeito à pessoa e à sustentabilidade das intervenções ao ambiente.

- Definição operacional: Envolvimento de discentes em projetos de extensão; Bolsistas de extensão.

- Dados primários: proposta de questões a serem aplicadas em instrumento de avaliação de egressos

- Seu curso oferece atividades complementares?

Resposta em escala de 5 níveis

- Você participou de programas de extensão? 
- Dados secundários/ Fonte de dados: SISTEC/MEC e Institutos Federais.

13. Atividades de pesquisa

- Definição constitutiva: Processo sistemático de desenvolvimento do método científico, realizado objetivando produzir novos conhecimentos. Distinguem-se três categorias: básica, aplicada e desenvolvimento experimental. A pesquisa básica é o estudo teórico que visa contribuir para a compreensão sobre os fatos e fenômenos observáveis, sem ter em vista aplicação específica imediata. A pesquisa aplicada é realizada para determinar os possíveis usos para as descobertas da básica ou para definir novos métodos de alcançar um objetivo específico. $O$ desenvolvimento experimental é o trabalho sistemático aplicado na produção ou aperfeiçoamento de novos materiais, produtos e sistemas (OCDE, 1993, p. 29).

- Definição operacional: Bolsistas PIBITI; Discentes em Iniciação Científica; Discentes em programas de pós-graduação; Grupo de pesquisa.

- Dados secundários/ Fonte de dados: CNPQ, CAPES e Institutos Federais.

14. Relação com Sistema de Ensino

- Definição constitutiva: Relação que se dá entre os sujeitos envolvidos no processo pedagógico das licenciaturas nos Institutos Federais e 
entre estes e os objetos do conhecimento no campo de prática. Tratase de uma relação de dependência ou influência recíproca.

- Definição operacional: Bolsistas do PIBID.

- Dados secundários/ Fonte de dados: CAPES.

15. Egressos qualificados para o trabalho

- Definição constitutiva: Conjunto de competências, habilidades e conhecimentos adquiridos para o exercício de uma atividade de trabalho. A qualificação não se cristaliza num determinado tempo, ao contrário, está em constante movimento em razão do permanente acumulo de experiência concretas de trabalho e de vida em geral e da aquisição de novos conhecimentos e habilidades, no trabalho, na escola e na vivência social. Desta forma, a qualificação é uma construção social, ao contrário dos que nela veem um processo essencialmente individual institucionais (FIDALGO E MACHADO, 2000, p.56)..

- Definição operacional: ocupação profissional do egresso.

- Dados primários: proposta de questões a serem aplicadas em instrumento de avaliação de egressos

- Atualmente, você está:

Trabalhando;

Trabalhando e estudando;

Apenas estudando;

Não está trabalhando e nem estudando.

- Qual a relação entre o seu trabalho atual e a sua formação técnica?

Fortemente relacionada com a área profissional do curso técnico;

Fracamente relacionada com o curso técnico anterior; 
Não tem nenhuma relação com o curso técnico anterior;

Não sabe /Não Opinou.

- Como é a exigência da sua capacitação profissional na atualidade?

Inferior a recebida no curso técnico em que se formou;

Compatível com a recebida no curso técnico;

Superior a recebida no curso técnico em que se formou.

- Você considera que seu curso contribui na preparação para o exercício profissional?

Resposta em escala de 5 níveis.

16. Egressos preparados para exercício da cidadania

- Definição constitutiva: Condição de pessoa que, como membro de um Estado, se acha no gozo de direitos que lhe permitem participar da vida política. Processo mediante o qual os membros de uma sociedade participam nos processos dinâmicos que a constituem. Dessa forma, elementos como a informação, a motivação e a educação agem sobre os indivíduos, tornando-os mais ou menos inclinados ao processo participativo institucionais (FIDALGO E MACHADO , 2000, p.50)..

- Definição operacional: formação geral do discente.

- Dados primários: proposta de questões a serem aplicadas em instrumento de avaliação de egressos

- O curso contextualiza o conhecimento da área com os temas gerais e situações do cotidiano da realidade brasileira?

Resposta em escala de 5 níveis.

- Como você avalia a contribuição do curso para a sua formação cidadã? 
Resposta em escala de 5 níveis.

17. Egressos com acesso à cultura

- Definição constitutiva: Valores, normas e modelos de comportamento característicos de toda a sociedade (as artes, por exemplo). Desse modo, a cultura geral e técnica não devem ser percebidas como antagônicas e sim como reciprocamente complementares, visto que ambas estabelecem dois aspectos do mesmo fenômeno que é a cultura humana.

- Definição operacional: Leitura extracurricular; atividade cultural.

- Dados primários: proposta de questões a serem aplicadas em instrumento de avaliação de egressos

- Excetuando-se os livros indicados na bibliografia do seu curso, quantos livros você leu este ano?

Resposta em escala de 5 níveis.

- Com qual frequência você frequenta teatros, cinemas, museus ou outro espaço cultural?

Resposta em escala de 5 níveis.

18. Soluções em tecnologias sociais

- Definição constitutiva: Compreende produtos, técnicas ou metodologias reaplicáveis, desenvolvidas na interação com a comunidade e que representem efetivas soluções de transformação social. Remete para 
uma proposta inovadora de desenvolvimento, considerando a participação coletiva no processo de organização, desenvolvimento e implementação. Está baseado na disseminação de soluções para problemas voltados a demandas de alimentação, educação, energia, habitação, renda, recursos hídricos, saúde, meio ambiente, dentre outras (IBICT).

- Definição operacional: Envolvimento discente em projetos de tecnologias sociais

- Dados primários: proposta de questões a serem aplicadas em instrumento de avaliação de egressos

- Durante seu curso você se envolveu em algum projeto de tecnologia social?

Resposta em escala de 5 níveis.

19. Soluções técnicas e Tecnológicas

- Definição constitutiva: Refere-se às técnicas, métodos, procedimentos, ferramentas, equipamentos e instalações que concorrem para a realização e obtenção de um ou vários produtos. O termo implica o que fazer, por quem, por quê, para quem e como fazer. Em geral, divide-se em duas grandes categorias: tecnologia de produto e tecnologia de processo. As de produto são aquelas cujos resultados são componentes tangíveis e facilmente identificáveis, tais como: equipamentos, instalações físicas, ferramentas, artefatos, etc. As de processo são aquelas em que se incluem as técnicas, métodos e procedimentos utilizados para se obter um determinado produto (IBICT). 
- Definição operacional: Bolsistas em projetos de pesquisa e inovação.

- Dados secundários/ Fonte de dados: CNPQ e CAPES.

20. Verticalidade

- Definição constitutiva: Continuidade com a qual o discente se relaciona com a instituição. Indicativo de sua confiança, comprometimento e satisfação com a Instituição tendo como externalidade positiva a retenção e reingresso do aluno em outras ofertas educativas.

- Definição operacional: discentes em continuidade de cursos da EPT.

- Dados primários: proposta de questões a serem aplicadas em instrumento de avaliação de egressos

- Você cursou outro curso de EPT neste Instituto Federal?

\subsection{TESTES DAS HIPÓTESES}

Para os testes das hipóteses foi construído um modelo de verificação inspirado no modelo teórico apresentado na seção anterior porém com um número de relações e variáveis reduzido.

Cada variável presente no modelo teve a seguinte definição operacional Tabela 9, conforme listada na Figura 32.

Figura 32-Modelo para teste de hipóteses 


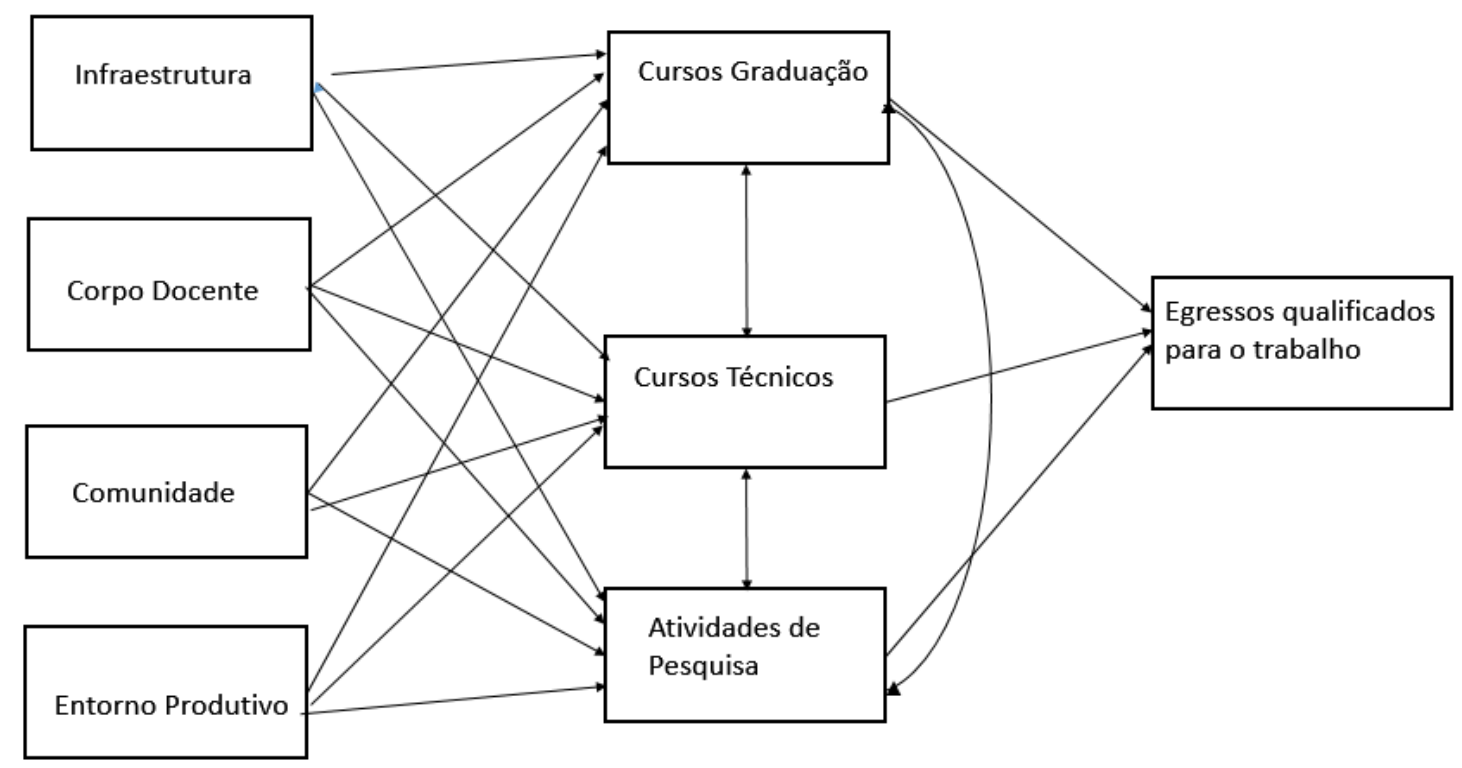

Fonte: Elaboração da autora

Tabela 9-Definição operacional de variáveis e constructos

\begin{tabular}{ll}
\hline VARIÁVEL/CONSTRUTO & DEFINIÇÃO OPERACIONAL \\
\hline Comunidade & Constructo definido a partir dos \\
& indicadores IDHM e IDEB \\
\hline Entorno Produtivo & Constructo definido a partir do PIB \\
& município e número de empresas atuantes \\
\hline Corpo Docente & Percentual de especialistas, mestres, \\
& doutores, respectivamente. \\
& Quantidade de docentes \\
\hline Infraestrutura & Conceito obtido quando da avaliação \\
& SINAES INEP na 3ª. Dimensão do \\
& instrumento de avaliação (infraestrutura) \\
\hline Cursos Técnicos & Quantidade de eixos tecnológicos \\
& Quantidade de cursos \\
\hline Cursos de Graduação & Quantidade de cursos \\
\hline
\end{tabular}




\begin{tabular}{ll}
\hline & Quantidade de eixos tecnológicos \\
& ENADE \\
\hline Atividades de Pesquisa & Grupos de pesquisa \\
& Bolsas PIBID \\
\hline Empregabilidade & Situação dos egressos no que se refere ao \\
& Trabalho segundo a Pesquisa Nacional de \\
& Egressos 2009, MEC/SETEC \\
\hline
\end{tabular}

Fonte: elaboração da autora

A partir do modelo para a verificação de hipóteses, procedeu-se a identificação da significância dos coeficientes de regressão (parâmetro estimado) através da análise do seu respectivo t-value. Valores de t-value superiores a 1,96 designam um nível de significância de no mínimo 0,05 e sustentam a hipótese. Em adição, valores de t-value superiores a 2,58 designam um nível de significância estatística de 1\% (GARVER e MENTZER, 1999; REICHELT, 2007).

Também foram calculadas as magnitudes dos parâmetros estimados, através das cargas fatoriais padronizadas $(\beta)$ das relações, que indicam a força de cada uma das relações estabelecidas (Hair et al., 1995).

A tabela 11 apresenta os caminhos estruturais preconizados pelo modelo, suas respectivas cargas fatoriais padronizadas $(\beta)$, t-values e os coeficientes de significância.

Tabela 10-Significância das Hipóteses

\begin{tabular}{lllccc}
\hline Hipótese & Enunciado & B & t-value & Sig \\
\hline H1 & A titulação dos professores influencia na & $\mathbf{0 , 4 8 3}$ & 6,161 & \\
& ampliação da oferta de cursos superiores. & & & \\
\hline H2 & A titulação do corpo docente e infraestrutura & $\mathbf{0 , 6}$ & 5,702 & \\
& laboratorial incidem positivamente na & $\mathbf{0 , 5 3}$ & & \\
& $\begin{array}{l}\text { qualidade dos cursos de graduação } \\
\text { ofertados. }\end{array}$ & & & & \\
& O crescimento da oferta de cursos & $\mathbf{0 , 3 6}$ & 6,76 & 0,0 \\
\hline H3 &
\end{tabular}




\begin{tabular}{|c|c|c|c|c|}
\hline & $\begin{array}{l}\text { superiores inibe o crescimento da oferta de } \\
\text { cursos técnicos. }\end{array}$ & & & \\
\hline $\mathrm{H} 4$ & $\begin{array}{l}\text { O contexto produtivo local exerce impacto } \\
\text { positivo na produção científica. }\end{array}$ & $-0,070$ & $-0,872$ & 0,383 \\
\hline $\mathrm{H} 5$ & $\begin{array}{l}\text { A maior especialização do Instituto influencia } \\
\text { o aumento na produção científica. }\end{array}$ & 0,002 & 0,016 & 0,987 \\
\hline $\mathrm{H} 6$ & $\begin{array}{l}\text { O contexto educativo influencia } \\
\text { positivamente a quantidade e diversidade de } \\
\text { cursos ofertados. }\end{array}$ & 0,299 & 2,988 & 0,003 \\
\hline $\mathrm{H} 7$ & $\begin{array}{l}\text { A titulação do corpo docente e a qualidade } \\
\text { da infraestrutura laboratorial impactam } \\
\text { positivamente na produção científica. }\end{array}$ & $\begin{array}{c}0,2 \\
0,23\end{array}$ & 7,005 & $\star \star \star *$ \\
\hline $\mathrm{H} 8$ & $\begin{array}{l}\text { A diversidade da oferta de cursos (técnicos e } \\
\text { tecnológicos) influencia na inserção laboral } \\
\text { dos egressos. }\end{array}$ & 0,74 & 19,24 & 0,0 \\
\hline $\mathrm{H} 9$ & $\begin{array}{l}\text { A qualidade da infraestrutura associada ao } \\
\text { entorno produtivo impacta positivamente a } \\
\text { empregabilidade do egresso. }\end{array}$ & 0,33 & 6,29 & 0,0 \\
\hline
\end{tabular}

Fonte: elaboração da autora

Os coeficientes de determinação $\left(R^{2}\right)$ para as variáveis dependentes do modelo também foram avaliados. Hair et al. (2009) explicam que o coeficiente de determinação $\left(R^{2}\right)$ pode variar de 0 a 1 , e que o pesquisador pode assumir que quanto maior for o valor de $\mathrm{R}^{2}$, maior o poder de explicação da equação de regressão e, portanto, melhor a previsão da variável dependente.

Os dados da Tabela 11 apresentam os coeficientes de explicação $\left(R^{2}\right)$ de cada construto endógeno do modelo.

Tabela 11-Coeficientes de explicação

\begin{tabular}{cc}
\hline CONSTRUTO & $\mathbf{R}^{\mathbf{2}}$ \\
\hline Comunidade & 0,652 \\
\hline Entorno Produtivo & 0,509 \\
\hline
\end{tabular}



Atividades de Pesquisa
0,837

Fonte: elaboração da autora

A partir da análise das cargas fatoriais padronizadas, t-values e significância das relações hipotéticas, é possível apresentar na Tabela 12 os resultados das hipóteses desenvolvidas neste estudo.

Tabela 12-Teste das Hipóteses

\begin{tabular}{|c|c|c|}
\hline & Hipótese & Resultado \\
\hline H1 & $\begin{array}{l}\text { A titulação dos professores influencia na ampliação da } \\
\text { oferta de cursos superiores. }\end{array}$ & $\mathrm{Col}$ \\
\hline $\mathrm{H} 2$ & $\begin{array}{l}\text { A titulação do corpo docente e infraestrutura laboratorial } \\
\text { incidem positivamente na qualidade dos cursos de } \\
\text { graduação ofertados. }\end{array}$ & \\
\hline H3 & $\begin{array}{l}\text { O crescimento da oferta de cursos superiores inibe } 0 \\
\text { crescimento da oferta de cursos técnicos. }\end{array}$ & \\
\hline H4 & $\begin{array}{l}\text { O contexto produtivo local exerce impacto positivo na } \\
\text { produção científica. }\end{array}$ & Refutada \\
\hline H5 & $\begin{array}{l}\text { A maior especialização do Instituto influencia o aumento na } \\
\text { produção científica. }\end{array}$ & Refutada \\
\hline H6 & $\begin{array}{l}\text { O contexto educativo influencia positivamente a quantidade } \\
\text { e diversidade de cursos ofertados. }\end{array}$ & Corroborada \\
\hline H7 & $\begin{array}{l}\text { A titulação do corpo docente e a qualidade da infraestrutura } \\
\text { laboratorial impactam positivamente na produção científica. }\end{array}$ & Cor \\
\hline H8 & $\begin{array}{l}\text { A diversidade da oferta de cursos (técnicos e tecnológicos) } \\
\text { influencia na inserção laboral dos egressos. }\end{array}$ & Cor \\
\hline H9 & $\begin{array}{l}\text { A qualidade da infraestrutura associada ao entorno } \\
\text { produtivo impacta positivamente a empregabilidade do } \\
\text { egresso. }\end{array}$ & Corroborada \\
\hline
\end{tabular}

Fonte: elaboração da autora 


\section{Coleta de dados}

Os dados utilizados nessa pesquisa são de fontes secundárias. A Tabela 13 apresenta a caracterização dos dados e sua fonte de origem.

Tabela 13-bases de dados utilizadas na pesquisa

\begin{tabular}{|c|c|c|}
\hline Dados & Origem & Fonte \\
\hline $\begin{array}{l}\text { Coord. geográficas } \\
\text { dos municípios } \\
\text { Brasileiros }\end{array}$ & IBGE & $\begin{array}{l}\text { http://downloads.ibge.gov.br/downloads_ } \\
\text { geociencias.htm }\end{array}$ \\
\hline $\begin{array}{l}\text { Dados selecionados } \\
\text { dos IFs (cursos, } \\
\text { matrículas, } \\
\text { modalidade, eixo, } \\
\text { tipo, etc) }\end{array}$ & MEC & $\begin{array}{l}\text { SISTEC (Sistema Nacional de } \\
\text { Informações da Educação Profissional e } \\
\text { Tecnológica) }\end{array}$ \\
\hline $\begin{array}{l}\text { Distâncias entre } \\
\text { municípios }\end{array}$ & $\begin{array}{l}\text { DENATRAN } \\
\text { Ministério das } \\
\text { Cidades }\end{array}$ & http://www.rotasdascidades.com.br/ \\
\hline $\begin{array}{l}\text { PIB per capita; } \\
\text { IDHM; Salário } \\
\text { Médio Mínimo; } \\
\text { Empresas atuantes; } \\
\text { Pessoal com } \\
\text { ocupação }\end{array}$ & IBGE & $\begin{array}{l}\text { http://downloads.ibge.gov.br/downloads_ } \\
\text { estatisticas.htm }\end{array}$ \\
\hline $\begin{array}{l}\text { Qualificação de } \\
\text { professores; } \\
\text { infraestrutura }\end{array}$ & INEP & www.inep.gov.br \\
\hline Dados do ENADE & INEP & www.inep.gov.br \\
\hline IDEB 2013 & INEP & www.inep.gov.br \\
\hline Grupos de pesquisa & CNPQ & www.cnpq.gov.br \\
\hline
\end{tabular}




\begin{tabular}{l|ll}
\hline Dados & Origem & Fonte \\
\hline PIBID & CAPES & www.capes.gov.br \\
\hline
\end{tabular}

Definição dos recursos e ferramentas utilizadas no tratamento e análise dos dados.

A diversificação e o grande volume das bases de dados trabalhadas nessa pesquisa, geraram a necessidade de desenvolver um aplicativo de banco de dados em ACCESS ${ }^{\circledR}$, denominado de Repositório de Análise da Rede de Institutos Federais sob a Ótica de Variáveis Selecionadas - Figura 33, com a finalidade de consolidar e realizar os devidos tratamentos dessas diferentes bases.

As bases de dados sofreram ajustes, complementações, consolidações e glosas para atendimento ao contexto das análises desse trabalho, bem como para o teste das hipóteses formuladas. 
Figura 33-Banco de dados desenvolvido no âmbito desta pesquisa

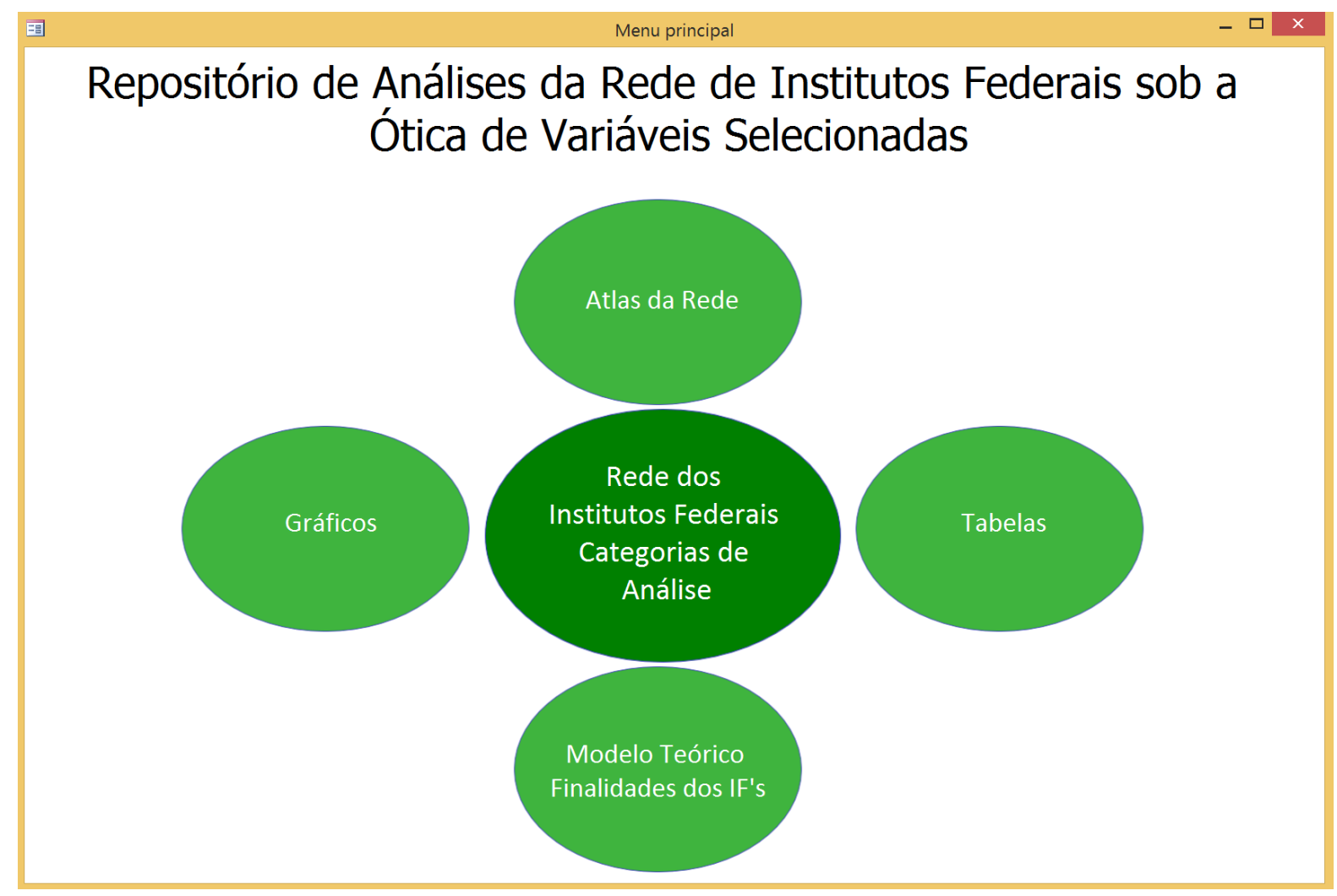

Fonte: Elaboração da autora.

O aplicativo de banco de dados tem como objetivo armazenar todos os dados e análises desta pesquisa. No hiperlink Atlas da Rede estão armazenados todos os mapas elaborados com o Google Fusion Tables ${ }^{\circledR}$. A base de gráficos e de tabelas são recursos dinâmicos que permitem executar cruzamentos de diversas bases de dados com diversas variáveis, possibilitando estratificar e visualizar recortes dos dados em diferentes dimensões. O hiperlink modelo teórico consolida os principais testes realizados nas hipóteses no âmbito desta pesquisa e sua respectiva documentação.

O Google Fusion Tables® foi utilizado na elaboração dos mapas georeferenciados. Essa e outras bases de dados, constantes no repositório, juntamente com as variáveis selecionadas possibilitaram criar arranjos e "olhares" diferenciados da Rede que, identificados em diversos mapas, deram origem ao Atlas da Rede Federal, anteriormente apresentado. 


\subsubsection{DISCUSSÃO DAS HIPÓTESES}

Nove hipóteses foram testadas, sendo que seis foram confirmadas pelos dados empíricos coletados. A seguir serão apresentadas as relações entre os construtos propostos no modelo de pesquisa e as hipóteses derivadas destas relações.

\section{Hipóteses 1 e 3.}

A nova institucionalidade conjugada à expansão demandou - na rede federal - a realização de diversos concursos para docentes, ou seja, tem atraído profissionais iniciantes no campo da educação profissional para compor o quadro de professores.

Ferretti (2010, p.3), Otranto (2011, p.13) observam que estes profissionais, são geralmente, advindos universidade, com formação "bacharelesca" e supostamente sem uma ampla e crítica visão da história e das finalidades da educação profissional no Brasil, tampouco das diferenças entre os projetos de educação técnica e educação tecnológica.

[...] a maioria dos novos professores que participam dos concursos e estão sendo contratados são mestres e doutores que querem e estão preparados para lecionar na educação superior, mas que também recebem turmas dos ensinos médio e técnico, quase sempre sem experiência neste nível e modalidade de ensino, para cumprir o que lei denomina de verticalização.

Dessa constatação, compartilhada pela autora desta tese - a partir de sua

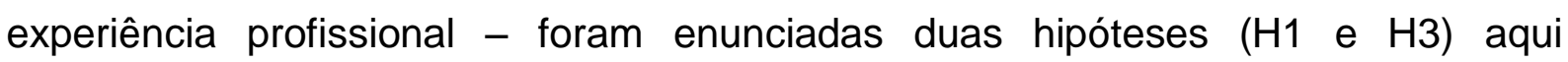
comentadas. 
Da análise estatística feita, percebe-se o impacto positivo e significante da titulação docente na oferta de cursos superiores. A hipótese 1 foi corroborada pelos dados empíricos $(\beta=0,483$ e $p<0,001)$, demonstrando importante impacto da titulação na oferta de cursos superiores. Entretanto, a hipótese 3 previa que "o crescimento da oferta de cursos superiores inibiria o crescimento da oferta de cursos técnicos" não foi corroborada. Através da análise dos dados empíricos, a hipótese H3 foi rejeitada $(\beta=0,36$ e $p>0,05)$.

Assim, diferentemente da suposição inicial desta pesquisa, não foi possível confirmar que haveria a probabilidade de decréscimo na oferta de cursos técnicos mediante a ampliação de cursos superiores. Alguns pontos podem explicar esta questão, dentre eles: o estímulo a oferta de cursos técnicos via PRONATEC e uma ação efetiva de monitoramento da previsão normativa legal de oferta de cursos técnicos.

\section{Hipóteses 2 e 7.}

A relação entre titulação e qualidade de infraestrutura laboratorial e seus reflexos na qualidade dos cursos e na produção científica tem sido defendida por uma série de estudos (DIAS SOBRINHO, 1997; FERREIRA, 2008; CUNHA, 2005). Tal relação fundamenta, inclusive, os instrumentos de avaliação utilizados pelo INEP em processos avaliativos no âmbito do Sistema Nacional de Avaliação do Ensino Superior.

Da análise sobre os dados empíricos efetuada não restou nenhuma controvérsia e ambas as hipóteses foram corroboradas.

Assim, a hipótese 2 "A titulação do corpo docente e infraestrutura laboratorial incidem positivamente na qualidade dos cursos de graduação ofertados" foi confirmada apresentando $(\beta=0,6$ e $\beta=0,53$ e $p>0,05)$. Importa ressaltar que a medida de qualidade para cursos de graduação utilizada foram os conceitos ENADE disponíveis de seus cursos superiores. Da mesma forma que a hipótese 7 "A titulação do corpo docente e a qualidade da infraestrutura laboratorial impactam positivamente na produção científica" também se confirmou com relação forte e 
positiva $(\beta=0,2$ e $\beta=0,23$ e $p>0,05)$. Esta foi por sinal a relação mais fortemente encontrada entre as hipóteses analisadas.

\section{Hipótese 4.}

Schwartzman (1998, p.5) ao destacar a necessidade de uma articulação do setor produtivo com o setor científico acadêmico faz severas críticas a situação vivenciada pela pesquisa nos idos da década de 90

vale notar que o projeto político implícito nessa política de ciência e tecnologia não consegue mobilizar senão apoio pontual no âmbito do sistema produtivo, caracterizando-se assim como um projeto restrito a um segmento particular da burocracia estatal e da comunidade acadêmica. Cabe registrar também que essa política, de maneira geral, não convergia com a política econômica e, em particular, com a política industrial implementada na maior parte do período - voltada sim para a promoção do processo de substituição de importações e de crescimento industrial do país, mas indiferente quanto à origem da tecnologia que viabilizava esse processo. SCHWARTZMAN (1998, p.5).

O autor também apontava para a pequena participação do sistema produtivo no financiamento do custeio de atividades científicas e tecnológicas, configurando assim, um pequeno comprometimento do setor produtivo privado com os gastos em ciência e tecnologia.

Contudo, entre o período observado no estudo e os dias atuais, foi promulgada a Lei de Inovação, de 2004, considerada um avanço importante porque deu sustentação legal ao financiamento da pesquisa no Brasil objetivando a criação de instrumentos para aumentar a competitividade das empresas nos mercados interno e externo e melhor aproveitar o capital intelectual do país, além do fomento aos Núcleos de Inovação Tecnológica para atuar nas instituições de ciência e tecnologia com a finalidade de gerir políticas de inovação.

Em função deste cenário foi enunciada a hipótese 4 "O contexto produtivo local exerce impacto positivo na produção científica”. Todavia, esta hipótese, a partir da análise dos dados empíricos não foi corroborada $(\beta=0,070, p>0,05)$. 
Assim, a pesquisa nos Institutos Federais traduzida por seus números de grupos de pesquisa não apresentou correlação direta com o entorno produtivo.

\section{Hipótese 5.}

As eventuais vantagens e limitações da especialização da oferta educativa nos Institutos Federais é uma discussão recorrente e teve seu ponto maior quando do período prévio à implantação da rede federa, em 2008. Provem desta observação, o enunciado desta hipótese "a maior especialização do Instituto influencia o aumento na produção científica".

Entretanto, apesar da aparente otimização de recursos e sinergia em suas atividades acadêmicas a especialização da oferta educativa dos Institutos Federais não implica numa maior produção científica. Este estudo, a partir de dados empíricos, rejeitou a hipótese H5 ( $\beta=0,002$ e $p>0,05)$.

\section{Hipótese 6.}

A hipótese 6, enunciada da seguinte maneira "o contexto educativo influencia positivamente a quantidade e diversidade de cursos ofertados" aborda a temática da influência da comunidade do município, em especial sua trajetória em níveis educacionais, e o consequente dinamismo de um instituto federal.

Tal hipótese advém das observações da autora desta tese ao longo do período em que trabalhou na Secretaria de Educação Profissional e Tecnológica. A hipótese investiga se os Institutos Federais "mimetizariam" as características educacionais dos municípios nos quais se localizam. Assim, um instituto localizado em um município com melhores indicadores educacionais teria também, ele próprio, um maior dinamismo em sua oferta educativa traduzido em quantidade e diversidade da oferta de seus cursos. 
Através da análise do t-value e coeficiente de regressão padronizado, verificou-se que a hipótese $\mathrm{H} 6$ foi confirmada pelos dados empíricos $(\beta=0,299$ e $p>$ $0,05)$.

Hipóteses 8 e 9.

As hipóteses 8 e 9 tem como variável dependente a inserção laboral do aluno, sua empregabilidade. $\mathrm{O}$ teste destas hipóteses usou como projeção desta empregabilidade os resultados obtidos quando da pesquisa de egressos da rede federal realizada em 2009.

Com relação à empregabilidade, Kyrillos (1998, p. 11) questiona:

Seriam os problemas encontrados na educação os responsáveis pela inadequação dos profissionais que necessitam estar aptos a conviver com tecnologias que buscam uma especialização flexível? Ou estaria na escola a solução para tais dificuldades? O sistema educacional, ultimamente, tem sofrido duras críticas e as avaliações têm mostrado os focos dessas. Se por um lado as ciências que focalizam o ambiente do trabalho, os valores, os anseios e as expectativas dos educadores não são completamente atendidos, por outro os educadores não possuem ou não recebem informações exatas a respeito da real situação do ambiente de trabalho e das profundas transformações pelas quais vem passando o sistema produtivo.

A atual competitividade do mercado de trabalho requer novas habilidades aos profissionais, dentre elas: maior independência e criatividade, além de conceitos subjetivos ligados ao comportamento e que valorizam a necessidade de auto realização e desenvolvimento pessoal.

Kyrillos (1998, p.13) enumera requisitos que incidem positivamente na inserção laboral, são eles:

a) experiência em áreas diferentes de atuação profissional - polivalência;

b) formação acadêmica, em áreas tais como eletrônica, mecânica, matemática aplicada, administração entre outras, e em segmentos diferenciados do conhecimento; 
c) utilização de ferramentas de comunicação e linguagem variadas; desde a escrita e a oralidade até aquelas que se utilizam da informática.

Outro princípio da educação profissional e tecnológica, a interdisciplinaridade, se apresenta como uma opção capaz de favorecer a integração curricular, uma vez que estimula a reorganização das áreas do conhecimento, sendo também referenciada pelos autores como favorecedora do êxito das comunidades escolares.

Assim, a interdisciplinaridade e o estímulo a polivalência parecem ser aspectos favorecidos por escolas que mantem alta diversidade na oferta de cursos, propiciando a troca e convívio entre corpo docente e discente e tendo reflexos na empregabilidade de seus egressos. A interdisciplinaridade na oferta de cursos favorece a polivalência, e esses dois aspectos não podem ser separados, pois são componentes das relações sociais concretas em que os alunos estão inseridos como cidadãos. Dessa forma, a hipótese 8 relacionando a diversidade da oferta de cursos (técnicos e tecnológicos) e sua influência na inserção laboral dos egressos foi corroborada $(\beta=0,74$ e $p>0,05)$.

Outro aspecto importante, diz respeito a qualidade do parque de instalações laboratoriais que favorece a consequente na formação enriquecida dos alunos. E o contexto produtivo no qual a escola está inserida.

Nesse contexto, manifesta-se Assis (1996, p.65):

As desigualdades em relação à educação têm hoje, conseqüências, além de causar diferenças sobre as oportunidades que se possa ter. receber ou não educação é condição para a participação na sociedade desde o momento em que, para desempenhar o exercício de muitas atividades e postos de trabalho, se requer uma preparação prévia, assim como ferramentas e habilidades para adquiri-la.

A opção pela profissionalização não universitária, tanto para quem elas se mostre como uma ação planejada como para quem ela represente maior possibilidade de participação na sociedade deve ser acompanhada de acesso a 
ferramental de qualidade favorecendo a atualização curricular e incidindo em vantagens competitivas quando da inserção laboral.

Ademais. Assis (1996, p. 95), em seu trabalho sobre a educação profissional e a encruzilhada entre as novas e velhas tecnologias, explana que: [...] no nível da atividade concreta do trabalhador tornam-se prioritários no novo paradigma conhecimentos sobre processo global de fabricação e gestão da produção, que se configuram como conhecimentos abrangentes e amplos do processo produtivo.

Na revolução, dita tecnológica, que vem impondo à questão educacional, particularmente para aquela direcionada à área da indústria, novos desafios, estar inserido num contexto produtivo favorável traduz em vantagens competitivas na inserção laboral dos estudantes. O contexto produtivo pujante parece favorecer que a escola acompanhe, mais facilmente, o ritmo de mudanças e das novas habilidades e competências requeridas pelas organizações produtivas, quanto se inteire das possibilidades da tecnologia aplicada ao ambiente de trabalho. Dessa maneira, a hipótese 9, a partir de dados empíricos, foi corroborada com ( $\beta=0,33$ e $p>0,05)$, ou seja, a qualidade da infraestrutura associada ao entorno produtivo impacta positivamente a empregabilidade do egresso.

No próximo capítulo serão apresentadas as conclusões desta tese, discutidos seus principais resultados, são também apresentadas as limitações da pesquisa e as indicações de pesquisas futuras. 


\section{CONCLUSÕES}

Na última década, o Brasil vivenciou o seu período mais expressivo, em toda a sua história, de crescimento de instituições de educação profissional e tecnológica. Ainda que este estudo se limitasse a entender tal crescimento, nas suas dimensões: quantitativa - da ordem de $300 \%$ - e qualitativa, novas finalidades atribuídas, já teria em mãos um interessante objeto de pesquisa. No entanto, considerar, adicionalmente, que estas instituições atuam na convergência de importantes políticas públicas no âmbito do trabalho, no âmbito da juventude, do desenvolvimento produtivo, da ciência, tecnologia e inovação e da educação torna o objeto deste estudo ainda mais desafiador em sua multidimensionalidade e complexidade.

Os resultados já apresentados tencionam responder ao problema de pesquisa desta tese: "Se os Institutos podem ser considerados como uma política pública inovadora, de que forma a proposição de um modelo teórico pode refletir essa inovação e permitir seu teste empírico?"

Assim, o objetivo central desta tese foi o de prover um referencial conceitual, analítico e metodológico sobre a nova institucionalidade da rede federal, contribuindo para o avanço do conhecimento na área via teste de hipóteses, proposição de tipologia de rede política, atlas da oferta, taxonomia dos Institutos Federais e ainda seu modelo teórico o que propiciará importantes subsídios a estudos futuros de avaliação desta política pública.

Para orientar o desenvolvimento da argumentação que sustenta esta pesquisa, delineou-se inicialmente o percurso histórico de constituição da rede federal e a trajetória do pensamento científico sobre o objeto empírico e teorias adjacentes. Posteriormente, recorreu-se à análise documental e a modelagem da pesquisa empírica com o estudo, utilização e composição de dados secundários advindos de distintas bases de dados oficiais.

Um primeiro resultado desta tese foi a proposição de uma Tipologia de Rede Política para os Institutos Federais que pode, entretanto, ser aplicada a 
qualquer outro conjunto de instituições escolares. O desenvolvimento desta tipologia ampara-se no conceito de rede política, definido como um conjunto de relações relativamente estáveis, de natureza não-hierárquica e independente, que vincula uma variedade de atores que compartilham interesses comuns em referência a uma política, e que fazem intercâmbio de recursos para perseguir esses interesses compartilhados, admitindo que a cooperação é a melhor maneira de alcançar as metas comuns (BONAFONT, 2004. p. 89). Neste contexto, esta tipologia ajuda a clarificar o mecanismo de governança da rede federal, em especial o CONIF - aqui denominado "a rede dentro da Rede" - num cenário de elevado grau de autonomia destas instituições, grande diversidade de realidades, diversos interesses envolvidos e, principalmente, diante do protagonismo e relevância da atuação destas instituições e de seu conjunto de dirigentes. Faz-se necessário frisar a ausência de uma entidade representativa na interlocução com o agente governamental que congregue além dos dirigentes de Institutos Federais, outros segmentos, igualmente importantes, a saber: setor produtivo, discentes, docentes e técnico-administrativos.

Posterior à proposição desta tipologia de rede política, foi igualmente proposta, uma Taxonomia dos Institutos Federais, com o objetivo de ampliar o entendimento sobre a pluralidade e multidimensionalidade envolvida no objeto em estudo. Com a taxonomia proposta espera-se contribuir para o aprofundamento do debate acerca dos Institutos Federais em pelo menos três aspectos:

i) no estabelecimento de critérios que permitam avaliar o impacto decorrente do contexto regional e setorial sobre suas potencialidades;

ii) no fornecimento de instrumentos analíticos que permitam o seu conhecimento e diferenciação; e

iii) na proposição de indicadores de avaliação que permitam uma conexão mais clara entre os institutos e as estratégias de desenvolvimento local e regional.

Esta tese apresenta, adicionalmente, como resultado um Atlas dos Institutos Federais, produto que reúne informações sintetizadas em categorias de análise envolvendo importantes indicadores sociais, a saber: PIB, IDEB, IDHM e outras fontes de dados. Esta seção objetiva oferecer ao leitor um panorama 
detalhado da diversidade e riqueza do objeto de estudo, Institutos Federais.

Aponta-se como traço distintivo desta tese o fato do desenvolvimento de um modelo teórico das finalidades dos Institutos Federais de Educação, Ciência e Tecnologia. Dessa forma, viu-se que a construção teórica das finalidades do instituto federal, de fato, delineia uma realidade complexa caracterizada pela participação simultânea de importantes aspectos. Desse modo uma vez, estabelecida as relações entre as variáveis associadas ao objeto em estudo, tornou-se desejável uma representação gráfica do fenômeno, fornecendo uma visão pictórica e facilitando a compreensão de seu caráter relacional. Ressalte-se que, para além do modelo teórico causal proposto, foram especificadas as definições constitutivas e operacionais de cada variável constante do modelo. A partir da utilização do modelo proposto deve ser possível determinar que fatores se mostram mais influentes na formação humana e profissional dos alunos egressos da rede federal e, por conseguinte, possibilitar estudos avaliativos acerca de sua qualidade educacional.

A proposição do modelo teórico de finalidades dos Institutos Federais conciliou aspectos de três dimensões:

- A dimensão do território: entorno sócio produtivo e suas especificidades;

- A dimensão da ação educativa: oferta de cursos, ações de pesquisa e extensão; e

- A dimensão do egresso: formação humana, cultural, cidadã e profissional.

Outro resultado da tese foi a proposição e verificação de um conjunto de hipóteses relacionadas aos Institutos Federais. Para realizar os testes de hipóteses foi necessário, como é usual nesses casos, a definição de um modelo relacional de hipóteses, a construção de uma base de dados e a utilização de um software estatístico, especificamente o IBM SPSS Statistical Package for the Social Sciences.

Da análise estatística das hipóteses verificadas, a partir de dados empíricos constata-se, sumariamente, que: 
(i) Foi corroborada o impacto positivo da titulação docente na oferta de cursos superiores $(\beta=0,483$ e $p<0,001)$;

(ii) Foi refutada a hipótese de que o crescimento da oferta de cursos superiores inibiria o crescimento da oferta de cursos técnicos $(\beta=0,36$ e $p>0,05)$;

(iii) A hipótese de que a titulação do corpo docente e infraestrutura laboratorial incidem positivamente na qualidade dos cursos de graduação ofertados foi confirmada ( $\beta=0,6$ e $\beta=0,53$ e $p>0,05$ );

(iv) A hipótese de que a titulação do corpo docente e a qualidade da infraestrutura laboratorial impactam positivamente a produção científica também se confirmou com relação forte e positiva $(\beta=0,2$ e $\beta=0,23$ e $p>0,05$ );

(v)Não foi corroborada a hipótese de que o contexto produtivo local exerce impacto positivo na produção científica $(\beta=0,070, p>0,05)$;

(vi) A hipótese de que uma maior especialização do Instituto influencia o aumento na produção científica foi rejeitada $(\beta=0,002$ e $p>0,05)$;

(vii) Foi corroborada a hipótese de que o contexto educativo influencia positivamente a quantidade e diversidade de cursos ofertados $(\beta=0,299$ e $p<0,01)$;

(viii) A hipótese de que a diversidade da oferta de cursos (técnicos e tecnológicos) influencia na inserção laboral dos egressos foi corroborada $(\beta=0,74$ e $p>0,05)$; e por fim

(ix) A hipótese de que a qualidade da infraestrutura associada ao entorno produtivo impacta positivamente a empregabilidade do egresso foi corroborada $(\beta=0,33$ e $p>0,05)$.

Do ponto de vista empírico, o estudo sobre o modelo de institucionalidade dos Institutos Federais abrange o espaço que simboliza o locus real, onde ocorre o aprendizado, são criadas as capacitações educativas e inovativas e fluem os conhecimentos tácitos; e representa o nível no qual as políticas de promoção do 
aprendizado, inovação e criação de capacitações podem ser mais efetivas. Este modelo permite estabelecer uma ponte entre condicionantes que operam nas esferas intra-escola e entre estas e o território proporcionando uma visão abrangente sobre a realidade.

Em síntese, o estudo sobre a institucionalidade dos Institutos Federais envolve um conjunto amplo e complexo de questões a partir dos quais é possível concluir, adicionalmente, que:

- A localização geográfica do instituto federal deve inspirar políticas diferenciadas que considerem as especificidades do território e seu respectivo estágio de desenvolvimento;

- A avaliação, atualmente implementada pelo SINAES, considera tão somente o segmento do ensino superior de graduação dos Institutos Federais, que the é minoritário. Resta lacunosa a avaliação de sua oferta educativa majoritária, cursos técnicos, bem como, sua oferta de qualificação profissional. Devido às peculiaridades da educação profissional e tecnológica, conclui-se pela não reprodução do mecanismo de avaliação da educação superior para outros níveis educacionais do instituto. Sugerindo-se, em seu lugar, uma proposição inovadora que considere o contexto produtivo e social, bem como a opinião e situação de seus egressos;

- A partir de bases de dados existentes - relacionados a educação e trabalho - e amparado em modelo relacional é possível traçar hipóteses e implementar o seu teste, no tocante aos Institutos Federais;

- Segundo os achados desta tese, os resultados de uma pesquisa de egressos, adicionados aos indicadores sociais existentes poderiam ser utilizados - amparados por um modelo relacional, aqui proposto - para a previsão de tendências, inferência de qualidade da oferta educativa e avaliação de efetividade da política pública de expansão. Contudo, um elo fundamental é faltante: a existência de pesquisas de egressos 
sistemáticas e periódicas;

- De forma mais empírica, esta pesquisa traz importantes elementos, que por um lado, retiram a ênfase de que a oferta de educação superior, nos institutos, seria predominante e danosa à oferta de cursos técnicos e caminha mais na direção que reforça aspectos do peso de sua historicidade e tradição na oferta de cursos técnicos. Existe uma influência mútua entre a oferta de cursos técnicos e de graduação, com a predominância, de seu matiz técnico;

- A implantação dos Institutos Federais requer acompanhamento para além de seus indicadores educacionais. Este acompanhamento deve entender esta implantação como um vetor de estímulo ao fomento à geração de renda e emprego, adensamento de cadeias produtivas regionais no entorno de grandes empreendimentos estruturantes ou mesmo na criação de novos eixos de desenvolvimento a partir de sistemas produtivos intensivos em conhecimento.

Dentre as limitações relacionadas a esta tese, é necessário frisar, que apesar de terem sido usadas técnicas de regressão linear para teste da relação entre variáveis - o que pode ser entendido como um caso específico da MEE, Modelagem de Equações Estruturais, o modelo teórico proposto não foi testado utilizando esta técnica. Tal fato configura-se tanto numa limitação do presente estudo quanto numa possibilidade de estudo futuro em continuidade a este. Ressalte-se, ainda, que o modelo teórico proposto foi pensado para ser validado, em sua complexidade, com a utilização do componente AMOS do SPSS, entretanto, tal teste foi prejudicado pela ausência de dados, na mesma base temporal das demais variáveis (ano de 2013) para as variáveis dependentes do modelo, a saber: egressos qualificados para o trabalho, com atuação cidadã e acesso à cultura. Tais dados poderão ser facilmente obtidos a partir da conclusão da pesquisa nacional de egressos, em andamento, conduzida pela SETEC/MEC.

Finalmente, espera-se que a proposição de um arcabouço analítico, modelo teórico, teste e discussão de hipóteses, das tipologias classificatórias 
apresentadas nessa tese contribuam para construção do conhecimento, fornecendo um quadro de referências, a partir do qual se busca compreender os processos de geração, difusão e uso de conhecimentos e da dinâmica educacional e inovativa no âmbito dos Institutos Federais. Com o instrumental desenvolvido, entende-se ser possível integralizar o ciclo de políticas públicas, na linha de uma avaliação que considere o entorno social, as cadeias produtivas, articulando políticas subjacentes que são fundamentais ao sucesso da política de expansão da rede federal de institutos. 


\section{REFERÊNCIAS}

AFONSO, Almerindo Janela. Avaliação Educacional/; regulação e emancipação para uma sociologia das políticas avaliativas contemporâneas. São Paulo: Cortez, 2000.

APOSTEL, Leo. Le Problème Formel des Classifications Empiriques in Centre National de Recherche de Logique / Société belge de Logique et Philosophie des Sciences (ed.), La Classification dans les Sciences, 157- 230, Bruxelles: Éditions J. Duculot S.A..1963

ARRETCHE, Marta. Tendências no estudo sobre avaliação. In: Rico, Elizabeth $M$. (org) Avaliação de Políticas Sociais: uma questão em debate. São Paulo: Cortez Editora, 1998.

ARRUDA, M.C.C. Políticas de Educação Profissional de nível médio: limites e possibilidades. In: Anais do II SEPNET. Belo Horizonte: UFMG, 2010.

ASSIS, Marcos. A educação e a formação profissional na encruzilhada das velhas e novas tecnologias. In: Novas tecnologias, trabalho e educação. Um debate multidisciplinar. 3a ed. Petrópolis: Vozes, 1996.

AZEVEDO, Fernando ET AL. Manifestos dos pioneiros da Educação Nova (1932) e dos educadores 1959. Recife: Fundação Joaquim Nabuco, Editora Massangana, 2010. 122 p. Coleção Educadores.

BARNETT, Ronald. Improving Higher Education - total quality care. Bristol, USA: SRHE and Open University Press, 1992. Disponível em < http://www.amazon.co.uk/Improving-Higher-Education-QualityResearch/dp/033509984X>. Acesso em 10.01.2014.

BELLONI, I. A função social da avaliação institucional. In: DIAS SOBRINHO, J.; RISTOFF, D. I. (Orgs.). Universidade desconstruída: avaliação institucional e resistência. Florianópolis: Insular, 2000, p. 37-58.

BERGER FILHO, R. Educação profissional no Brasil: novos rumos. Revista Iberoamericana de Educación. Madri, n.20, mai/ago, 1999. 
BERTOLIN, Julio. Avaliação da qualidade do sistema de educação superior brasileiro em tempos de mercantilização - período 1994-2003. 2007. 281 f. Tese (Doutorado em Educação) - Universidade Federal do Rio Grande do Sul, Porto Alegre, 2007.

BORDIGNON, Genuíno. Conselhos Escolares: uma estratégia de gestão democrática da educação pública. Brasília: Ministério da Educação/Secretaria da Educação Básica, 2004.

BONAFONT, Laura. 2004. Redes de Políticas Públicas Madrid: Centro de Investigaciones Sociológicas. 2004

BRASIL. Decreto no 7.566, de 23 de setembro de 1909. Créa Escolas de Aprendizes Artícifes. Diário Oficial, Poder Executivo, Brasília, DF, 23 set. 1909.

BRASIL. Lei o 9.649, de 27 de maio de 1998. Dispõe sobre a organização da Presidência da República e dos Ministérios, e dá outras providências. Diário Oficial da União, Poder Legislativo, Brasília, DF, 28 mai. 1998.

BRASIL. Constituição da República Federativa do Brasil: promulgada em 10 de novembro de 1937. Série Legislação Brasileira, 1937.

BRASIL. Decreto Federal n. 2208, de 17 de abril de 1997. Regulamenta o § 2 do art. 36 e os arts. 39 a 42 da Lei Federal n. 9.394 de 1996, 1997.

BRASIL. Decreto no 1.606, de 29 de dezembro de 1906. Cria o Ministério dos Negócios da Agricultura, Indústria e Comércio. Collecção das Leis da República dos Estados Unidos do Brazil - 1906. Rio de Janeiro: Imprensa Nacional, v.1, 1906.

BRASIL. Lei no 11.892, de 29 dezembro de 2008. Institui a Rede Federal de Educação Profissional, Científica e Tecnológica. Diário Oficial da União, Poder Legislativo, Brasília, DF, 30 dez. 2008.

CIAVATTA, Maria. Universidades tecnológicas horizonte dos Institutos Federais de Educação, Ciência e Tecnologia (IFETS)?. In: MOLL, Jaqueline (Org.). Educação Profissional e Tecnológica no Brasil Conteporâneo: desafios, tensões e possibilidades. Porto Alegre: Artmed Editora, 2009. p. 159-174.

COSTA E SILVA, Cleide Maria Rodrigues Clímaco. Uma contribuição à definição de indicadores de desempenho de Instituições Federais de Educação Tecnológica do Brasil na abordagem do balanced scorecard. 2008. $88 \mathrm{f}$. Dissertação (Mestrado em Engenharia da Produção) - Universidade Federal do Rio 
Grande do Norte, Natal, 2008.

CUNHA, Luiz Antônio. O ensino profissional na irradiação do industrialismo. 2 ed. São Paulo: Editora UNESP, 2005.

DIAS SOBRINHO, José. Avaliação Quantitativa e Avaliação Qualitativa: Interações e Ênfases. In: SGUISSARDI, V. Avaliação universitária em questão: reformas do estado e da educação superior. (Org.). Campinas: Autores Associados, 1997.

DIAS SOBRINHO, José. Avaliação: políticas educacionais e reformas da educação superior. São Paulo: Cortez, 2003.

DYE, Thomas R. Mapeamento dos modelos de análise de políticas públicas. In: HEIDEMANN, Francisco G. e SALM, José Francisco (Orgs.). Políticas públicas e desenvolvimento: bases epistemológicas e modelos de análise. Brasília: Editora Universidade de Brasília, 2009. p. 99-132.

FARIAS, Salomão Alencar de; SANTOS, Rubens da Costa. Modelagem de equações estruturais e satisfação do consumidor: uma investigação teórica e prática. Rev. adm. contemp., Curitiba, v. 4, n. 3, Dec. 2000 . Disponível em $<$ http://www.scielo.br/scielo.php?script=sci_arttext\&pid=S1415$65552000000300007 \&$ lng=en\&nrm=iso >. Acesso em 12.03.2014.

FERREIRA, Getúlio Marques. Avaliação de desempenho de Instituições de Ensino Tecnológico aplicando análise envoltória de dados - DEA: um estudo no Brasil. 2007. 98 f. Dissertação (Mestrado em Engenharia da Produção) Universidade Federal do Rio Grande do Norte, Natal, 2008.

FIDALGO, Fernando; MACHADO, Lucília Regina de Souza. Dicionário da Educação Profissional. Belo Horizonte: Núcleo de Estudos sobre Trabalho e Educação, 2000.

FREITAG, Barbara. Escola, Estado e sociedade. 7 ed. São Paulo: Centauro Editora, 2005.

FRIGOTTO, Gaudêncio; CIAVATTA, Maria. Educação básica no Brasil na década de 1990: subordinação ativa e consentida à lógica do mercado. Educ. Soc., Campinas , v. 24, n. 82, Abr. 2003 Dísponível em

<http://www.scielo.br/scielo.php?script=sci_arttext\&pid=S0101-

$73302003000100005 \&$ Ing=en\&nrm=iso >. Acesso em 12.03.2014. 
FRIGOTTO, Gaudêncio; CIAVATTA, Maria. A formação do cidadão produtivo: a cultura de mercado no ensino médio técnico. Brasília: INEP Instituto de Pesquisas Educacionais Anísio Teixeira, 2006. p. 283-310.

GILBERT, John. , \& BOULTER, Clark. (1995). Stretching models too far. Paper presented at the Annual Meeting of the American Educational Research Association, San Francisco, 22-26 April.

HAIR, J.; WILLIAM, B.; BABIN, B.; ANDERSON, R.; TATHAM, R. Análise Multivariada de Dados. 6트 Edição. Porto Alegre: Bookman, 2009.

HALLOUN, Ibrahim. (2004). Modeling Theory in Science Education. Dordrecht: Kluwer.

HARVEY, Lee; GREEN, Diana. Definig Quality. Assessment \& Evaluation in Higher Education, vol. 18 Issue 1, p. 9-26, Abr.1993.

HEIDEMANN, Francisco G. Do sonho do progresso às políticas de desenvolvimento. In: HEIDEMANN, Francisco G. e SALM, José Francisco (Orgs.). Políticas públicas e desenvolvimento: bases epistemológicas e modelos de análise. Brasília: Editora Universidade de Brasília, 2009. p. 23-40.

IBICT. Rede Nacional de Transferência e Difusão de Tecnologias Apropriadas. Capturado em 13 Ago. 2013. On line. Disponível na Internet .http:// www.ibict.br

INDICADOR. In: HOUAISS Dicionário. 4. ed. São Paulo: Editora Objetiva, 2009.

JANNUZZI, Paulo de Martino. Indicadores Sociais no Brasil: conceitos, fontes de dados e aplicações. Barcelona, Espanha: Octaedro, 2004.

KAPLAN, David. Structural Equation Modelling: Foundations and Extensions. Thousand Oak: sage Publications, 2000

KERLINGER, Fred. Metodologia da pesquisa em ciências sociais: um tratamento conceitual. São Paulo: EPU, 1980.

KYRILLOS, Sérgio. Empregabilidade e Educação Para Empreendedores.

Disponível em: <http://www.ifsp.br>. Acesso em: 03 nov. 2014. 
KUENZER, A.Z. A educação profissional nos anos 2000: a dimensão subordinada das políticas de inclusão. Educ. Soc., vol. 27, n.96, out - Especial. Campinas, 2006.

KUNZE, N.C. O surgimento da rede Federal de Educação Profissional nos Primórdios do Regime Republicano Brasileiro. Revista Brasileira de educação Profissional e Tecnológica, v.2, .n.2., Brasília, nov. 2009. p. 9-24.

LEMAITRE, Maria José. Qualidade no ensino superior: desafios e perspectivas para a américa latina. Boletim técnico do Senac, Rio de Janeiro, v. 37, no 2, mai./ago. 2011

LEMME, Paschoal. O manifesto dos pioneiros da educação nova e suas repercussões na realidade educacional brasileira. Revista Brasileira de Estudos Pedagógicos, Brasília, v. 86, n. 212, p. 163-178, jan./abr. 2005.

LIMA FILHO, Domingos Leite. Universidade tecnológica e redefinição da institucionalidade da educação profissional. In: MOLL, Jaqueline (Org.). Educação Profissional e Tecnológica no Brasil Contemporâneo: desafios, tensões e possibilidades. Porto Alegre: Artmed Editora, 2009. p. 141-158.

MACHADO, Lucília Regina De Souza. Saberes profissionais nos planos de desenvolvimento de Institutos Federais de educação. Cad. Pesqui., São Paulo, v. 41, n. 143, Aug. 2011.

MACRAE, Dunkan Jr. Policy indicators: links between social Science and public debate. Chapel Hill: The University of North Carolina Press, 1985.

MINISTÉRIO DA EDUCAÇÃO. Secretaria de Educação Profissional e Tecnológica. Brasília, 2008. Disponível em: <http://portal.mec.gov.br/setec/>. Acesso em 01.10 .2009 .

MINISTÉRIO DO ORÇAMENTO, PLANEJAMENTO E GESTÃO. Indicadores de Programas: guia metodológico. Secretaria de Planejamento e Investimentos Estratégicos. Brasília: MPOG, 2010, 128 p.

OTRANTO, Célia Regina. A Política de Educação Profissional do Governo Lula. In: Anais eletrônicos da 34를 Reunião Anual da ANPED, Natal, RN, 2011.

OTRANTO, Célia Regina. A reforma da educação superior do governo Lula: da inspiração à implantação. In: SILVA Jr., João dos Reis; OLIVEIRA, João Ferreira; 
MANCEBO, Deise (Orgs.). Reforma universitária: dimensões e perspectivas. Campinas, SP: Editora Alínea, 2006, p.43-58.

OTRANTO, Célia Regina. Criação e implantação dos Institutos Federais de Educação, Ciência e Tecnologia - IFETs. In: Revista RETTA (PPGEA/UFRRJ), Ano I, no 1, jan-jun 2010, p.89-110.

PACHECO, Eliezer. Os Institutos Federais: Uma revolução na educação profissional e tecnológica. (s.d). Disponível em:

<http://portal.mec.gov.br/setec/arquivos/pdf2/artigos>. Acesso: 22 fev. 2012.

PACHECO, Eliezer. SETEC/MEC: Bases para uma Política Nacional de EPT. (2008). Disponível em: <http://portal.mec.gov.br/setec/arquivos/pdf2/artigos>. Acesso em: 22 fev. 2012.

PEREIRA, Luiz Augusto Caldas. Institutos Federais de Educação, Ciência e Tecnologia. (s.d). Disponível em:

<http://portal.mec.gov.br/setec/arquivos/pdf2/artigos>. Acesso em: 22 fev. 2012.

PASQUALI L. Princípios de elaboração de escalas psicológicas. In: Gorenstein C, Andrade LHSG, Zuardi AW, editores. Escalas de avaliação clínica em psiquiatria e psicofarmacologia. São Paulo: Lemos; 2000. p. 15-21.

PEREZ, Iriarte. Indicadores para políticas educativas de calidad em España. Madrid, Espanha: Santillana, 2002.

PNUD et al. Desenvolvimento humano e condições de vida: indicadores brasileiros. Brasília: PNUD, 1998.

RAMOS, Marise. A reforma do ensino médio técnico nas Instituições Federais de Educação Tecnológica: da legislação aos fatos. In: FRIGOTTO, Gaudêncio e CIAVATTA, Maria Available from $<$ http://www.scielo.br/scielo.php?script=sci_arttext\&pid=S0100$15742011000200003 \&$ Ing=en\&nrm=iso $>$. access on 11 May 2012. http://dx.doi.org/10.1590/S0100-15742011000200003.

SARRAMONA, Jaume. Factores e indicadores de calidad em la educación. Barcelona, Espanha: Octaedro, 2004.

SAVIANI, Demerval. História das idéias pedagógicas no Brasil. Campinas: 
Autores associados, 2008.

SCHARPF, Fred. Games Real Actors Play - Actor-Centered Institutionalism in Policy. Research. Westview Press, 1997.

SCHNEIDER, Anne Larason. Pesquisa avaliativa e melhoria da decisão política: evolução histórica e guia prático. In: HEIDEMANN, Francisco G. e SALM, José Francisco (Orgs.). Políticas públicas e desenvolvimento: bases epistemológicas e modelos de análise. Brasília: Editora Universidade de Brasília, 2009. p. 311-338.

SCHWARTZMAN, Simon, ed. 1982. Universidades e instituições científicas no Rio de Janeiro. Brasília: Conselho Nacional de Desenvolvimento Científico Tecnológico.

SILVA, Jorge Ferreira da; ROCHA, Ângela da. Réplica 2 - a estrutura intelectual da produção científica de alianças estratégicas: impressionismo ou realismo?.Rev. adm. contemp., Curitiba , v. 14,n. 4,Aug. 2010 . Disponível em <http://www.scielo.br/scielo.php?script=sci_arttext\&pid=S1415$65552010000400012 \&$ Ing=en\&nrm=iso $>$. Acesso em 30 Nov.

SOBRINHO, Moisés Domingos. Universidade Tecnológica ou Instituto Federal de Educação, Ciência e Tecnologia. (s.d). Disponível em:<http://portal.mec.gov.br/setec/arquivos/pdf2/artigos>. Acesso: 22 fev. 2012.

TEIXEIRA, Mônica e ARRUDÃO, Bias. Indicadores da educação da OCDE. Publicação mostra acesso diminuto a ensino superior no país, com melhoria muito lenta; investimento em relação ao PIB melhora. Disponível em: <http://www.inovacao.unicamp.br/report/noticias/index.php?cod=602>. Acesso em: 10 jan. 2012.

VAN BELLEN, Hans Michael. Indicadores de Sustentabilidade: uma análise comparativa. Rio de Janeiro: Editora FGV, 2006.

VOSNIADOU, Sean. (2002). Mental Models in Conceptual Development. In L. Mangani, N.J. Nersessian \& P. Thagard (eds.) Model Based Reasoning in Scientific Discovery. (pp. 353-368) New York: Kluwer. 


\section{ANEXO I - DEFINIÇÃO DE CONSTRUCTOS}

O desafio da utilização de constructos relaciona-se a conceituação clara e precisa dos fatores para os quais se quer construir o instrumento de medida. Novamente, de forma usual, recorre-se a literatura pertinente, aos especialistas da área e à própria experiência. Na definição dos constructos, são esperados dois produtos: as definições constitutivas e as definições operacionais.

\section{A definição constitutiva}

A definição constitutiva realiza a construção conceitual do constructo por meio de outros conceitos, ou seja, os conceitos, que são realidades abstratas, são definidos em termos de realidades abstratas. Por exemplo, se a inteligência verbal for definida como a "capacidade de compreender a linguagem", estamos diante de uma definição constitutiva, porque capacidade de compreender constitui uma realidade abstrata, um construto, um conceito (PASQUALI, 2000, p.17).

Delimitar de forma constitutiva os constructos é de muita relevância por pois proporcionam os contornos teóricos. Assim, definições dessa natureza impõem limitações definidas sobre o que se deve explorar quando o construto estiver sendo medido, limitações não somente em termos de fronteiras que não podem ser ultrapassadas, porém, mais ainda, em termos de fronteiras que devem ser alcançadas.

Usualmente a amplitude semântica de uma conceito não é alcançada por um instrumento que mede um construto. Assim, o grau de acerto nas definições constitutivas incidem na qualidade do instrumento, que mede o construto em termos de extensão semântica. Disso, decorrem instrumentos melhores e piores à medida que medem mais ou menos da extensão conceitual do construto, extensão essa delimitada pela definição constitutiva desse mesmo construto (PASQUALI, 2000, p.17). 


\section{A definição operacional}

Após as definições constitutiva, ainda, situa-se no campo da teoria, do abstrato. Aí decorre a necessidade de migrar do abstrato para o concreto, visto que um instrumento de medida é uma operação concreta, empírica. A definição operacional dos construtos, é, talvez, a etapa de maior criticidade na construção de medidas, almejando a legitimidade da representação empírica dos traços latentes (os construtos).

Duas preocupações são relevantes e decisivas neste momento: 1) as definições operacionais dos construtos devem ser realmente operacionais e 2) devem ser o mais abrangente possível. Esta tautologia é proposital, porque uma definição de um construto somente é operacional quando o mesmo é definido, não mais em termos de outros construtos, mas em termos de operações concretas, isto é, de medidas através dos quais o tal construto se expressa.

Assim, se inteligência verbal for definida como a "capacidade de compreender uma frase" ou, mesmo "compreender uma frase", estamos diante de uma definição constitutiva e não operacional. Isto porque compreender não é um comportamento, mas um construto. Seria uma definição operacional de compreensão da frase, reproduzir a frase com outras palavras.

Quanto à abrangência, nenhuma definição operacional esgota a amplitude semântica de um construto; assim, podem haver definições operacionais mais ou menos abrangentes do mesmo construto e essa grandeza de abrangência, evidentemente, fala da boa, má ou pior qualidade da definição operacional, o que vai obviamente repercutir sobre o instrumento de medida do construto, que será baseado nesta definição operacional (PASQUALI, 2000, p.17). Aliás, uma definição operacional pode ser perfeitamente operacional e também equivocada ou errada, quando esta não cobrir nada do espaço semântico próprio do construto.

Assim definir inteligência verbal como "desenhar círculos na areia" constitui uma definição perfeitamente operacional, pois todo o mundo entende quando se manda desenhar círculos na areia; contudo, apesar de operacional, ela é 
uma definição perfeitamente equivocada de inteligência verbal, pois o comportamento de desenhar círculos na areia não tem nada a ver com o construto em questão.

Para garantir melhor cobertura do construto, as definições operacionais deverão especificar e elencar aquelas categorias, que seriam a representação comportamental do construto. Quanto melhor e mais completa for esta especificação, melhor será a garantia de que o instrumento que resultar para a medida do construto será válido e útil. Por exemplo, quais seriam as categorias de comportamentos que expressariam a compreensão verbal? Seriam tais como: reproduzir texto, dar sinônimos e antônimos, explicar o texto, etc. O desafio será alcançar uma representação clara e suficiente que permita a abordagem científica apropriada (PASQUALI, 2000, p.17) 


\section{ANEXO II - DISTRIBUIÇÃO DA OFERTA DE CURSOS DA EPT NOS INSTITUTOS FEDERAIS EM 2013}

\begin{tabular}{l|cc}
\hline Institutos & Qtd. & \\
\hline Instituto Federal de Educação, Ciência e Tecnologia Baiano & $\%$ \\
\hline 1 - FIC & 109 & 1,14 \\
2 - Cursos técnicos & 8 & 7,34 \\
3 - Cursos de graduação & 65 & 59,63 \\
4 - Especialização & 31 & 28,44 \\
Instituto Federal de Educação, Ciência e Tecnologia Catarinense & 5 & 4,59 \\
\hline 1 - FIC & 101 & 1,06 \\
\hline - Cursos técnicos & 1 & 0,99 \\
3 - Cursos de graduação & 61 & 60,40 \\
5 - Mestrado & 38 & 37,62 \\
Instituto Federal de Educação, Ciência e Tecnologia da Bahia & 1 & 0,99 \\
\hline 2 - Cursos técnicos & 118 & 1,24 \\
\hline - Cursos de graduação & 99 & 83,90 \\
Instituto Federal de Educação, Ciência e Tecnologia da Paraíba & 19 & 16,10 \\
\hline 1 - FIC & 254 & 2,67 \\
\hline - Cursos técnicos & 12 & 4,72 \\
3 - Cursos de graduação & 115 & 45,28 \\
4 - Especialização & 112 & 44,09 \\
5 - Mestrado & 11 & 4,33 \\
Instituto Federal de Educação, Ciência e Tecnologia de Alagoas & 4 & 1,57 \\
\hline 1 - FIC & 171 & 1,80 \\
\hline 2 - Cursos técnicos & 3 & 1,75 \\
3 - Cursos de graduação & 111 & 64,91 \\
4 - Especialização & 48 & 28,07 \\
5 - Mestrado & 8 & 4,68 \\
Instituto Federal de Educação, Ciência e Tecnologia de Brasília & 1 & 0,58 \\
\hline 1 - FIC & 155 & 1,63 \\
\hline - Cursos técnicos & 39 & 25,16 \\
3 - Cursos de graduação & 70 & 45,16 \\
4 - Especialização & 32 & 20,65 \\
5 - Mestrado & 12 & 7,74 \\
Instituto Federal de Educação, Ciência e Tecnologia de Goiás & 2 & 1,29 \\
\hline 1 - FIC & 288 & 3,02 \\
\hline
\end{tabular}




\begin{tabular}{|c|c|c|}
\hline Institutos & $\begin{array}{l}\text { Qtd. } \\
\text { Curso }\end{array}$ & $\%$ \\
\hline 2 - Cursos técnicos & 96 & 33,33 \\
\hline 3 - Cursos de graduação & 84 & 29,17 \\
\hline 4 - Especialização & 10 & 3,47 \\
\hline 5 - Mestrado & 4 & 1,39 \\
\hline Instituto Federal de Educação, Ciência e Tecnologia de Mato Grosso & 202 & 2,12 \\
\hline $1-\mathrm{FIC}$ & 12 & 5,94 \\
\hline 2 - Cursos técnicos & 94 & 46,53 \\
\hline 3 - Cursos de graduação & 65 & 32,18 \\
\hline 4 - Especialização & 3 & 1,49 \\
\hline 5 - Mestrado & 24 & 11,88 \\
\hline 6 - Doutorado & 4 & 1,98 \\
\hline Instituto Federal de Educação, Ciência e Tecnologia de Mato Grosso do Sul & 309 & 3,25 \\
\hline $1-\mathrm{FIC}$ & 41 & 13,27 \\
\hline 2 - Cursos técnicos & 193 & 62,46 \\
\hline 3 - Cursos de graduação & 75 & 24,27 \\
\hline Instituto Federal de Educação, Ciência e Tecnologia de Minas Gerais & 168 & 1,76 \\
\hline $1-\mathrm{FIC}$ & 28 & 16,67 \\
\hline 2 - Cursos técnicos & 81 & 48,21 \\
\hline 3 - Cursos de graduação & 44 & 26,19 \\
\hline 4 - Especialização & 12 & 7,14 \\
\hline 5 - Mestrado & 3 & 1,79 \\
\hline Instituto Federal de Educação, Ciência e Tecnologia de Pernambuco & 356 & 3,74 \\
\hline $1-\mathrm{FIC}$ & 57 & 16,01 \\
\hline 2 - Cursos técnicos & 234 & 65,73 \\
\hline 3 - Cursos de graduação & 53 & 14,89 \\
\hline 4 - Especialização & 9 & 2,53 \\
\hline 5 - Mestrado & 3 & 0,84 \\
\hline Instituto Federal de Educação, Ciência e Tecnologia de Rondonia & 108 & 1,13 \\
\hline $1-\mathrm{FIC}$ & 18 & 16,67 \\
\hline 2 - Cursos técnicos & 41 & 37,96 \\
\hline 3 - Cursos de graduação & 26 & 24,07 \\
\hline 4 - Especialização & 23 & 21,30 \\
\hline Instituto Federal de Educação, Ciência e Tecnologia de Roraima & 119 & 1,25 \\
\hline $1-\mathrm{FIC}$ & 23 & 19,33 \\
\hline 2 - Cursos técnicos & 45 & 37,82 \\
\hline 3 - Cursos de graduação & 18 & 15,13 \\
\hline 4 - Especialização & 32 & 26,89 \\
\hline 5 - Mestrado & 1 & 0,84 \\
\hline Instituto Federal de Educação, Ciência e Tecnologia de Santa Catarina & 765 & 8,03 \\
\hline $1-\mathrm{FIC}$ & 351 & 45,88 \\
\hline 2 - Cursos técnicos & 244 & 31,90 \\
\hline 3 - Cursos de graduação & 120 & 15,69 \\
\hline 4 - Especialização & 30 & 3,92 \\
\hline 5 - Mestrado & 20 & 2,61 \\
\hline
\end{tabular}




\begin{tabular}{|c|c|c|}
\hline Institutos & $\begin{array}{c}\text { Qtd. } \\
\text { Curso }\end{array}$ & $\%$ \\
\hline Instituto Federal de Educação, Ciência e Tecnologia de São Paulo & 634 & 6,66 \\
\hline $1-\mathrm{FIC}$ & 146 & 23,03 \\
\hline 2 - Cursos técnicos & 305 & 48,11 \\
\hline 3 - Cursos de graduação & 150 & 23,66 \\
\hline 4 - Especialização & 27 & 4,26 \\
\hline 5 - Mestrado & 6 & 0,95 \\
\hline Instituto Federal de Educação, Ciência e Tecnologia de Sergipe & 227 & 2,38 \\
\hline $1-\mathrm{FIC}$ & 3 & 1,32 \\
\hline 2 - Cursos técnicos & 152 & 66,96 \\
\hline 3 - Cursos de graduação & 62 & 27,31 \\
\hline 4 - Especialização & 10 & 4,41 \\
\hline Instituto Federal de Educação, Ciência e Tecnologia de Tocantins & 121 & 1,27 \\
\hline 2 - Cursos técnicos & 82 & 67,77 \\
\hline 3 - Cursos de graduação & 39 & 32,23 \\
\hline Instituto Federal de Educação, Ciência e Tecnologia do Acre & 49 & 0,51 \\
\hline 2 - Cursos técnicos & 31 & 63,27 \\
\hline 3 - Cursos de graduação & 17 & 34,69 \\
\hline 5 - Mestrado & 1 & 2,04 \\
\hline Instituto Federal de Educação, Ciência e Tecnologia do Amapá & 59 & 0,62 \\
\hline $1-\mathrm{FIC}$ & 14 & 23,73 \\
\hline 2 - Cursos técnicos & 33 & 55,93 \\
\hline 3 - Cursos de graduação & 12 & 20,34 \\
\hline Instituto Federal de Educação, Ciência e Tecnologia do Amazonas & 289 & 3,04 \\
\hline $1-\mathrm{FIC}$ & 6 & 2,08 \\
\hline 2 - Cursos técnicos & 192 & 66,44 \\
\hline 3 - Cursos de graduação & 45 & 15,57 \\
\hline 4 - Especialização & 27 & 9,34 \\
\hline 5 - Mestrado & 17 & 5,88 \\
\hline 6 - Doutorado & 2 & 0,69 \\
\hline Instituto Federal de Educação, Ciência e Tecnologia do Ceará & 308 & 3,23 \\
\hline 2 - Cursos técnicos & 168 & 54,55 \\
\hline 3 - Cursos de graduação & 137 & 44,48 \\
\hline 4 - Especialização & 1 & 0,32 \\
\hline 5 - Mestrado & 2 & 0,65 \\
\hline Instituto Federal de Educação, Ciência e Tecnologia do Espírito Santo & 375 & 3,94 \\
\hline $1-\mathrm{FIC}$ & 51 & 13,60 \\
\hline 2 - Cursos técnicos & 218 & 58,13 \\
\hline 3 - Cursos de graduação & 75 & 20,00 \\
\hline 4 - Especialização & 21 & 5,60 \\
\hline 5 - Mestrado & 8 & 2,13 \\
\hline 6 - Doutorado & 2 & 0,53 \\
\hline Instituto Federal de Educação, Ciência e Tecnologia do Maranhão & 421 & 4,42 \\
\hline 2 - Cursos técnicos & 273 & 64,85 \\
\hline 3 - Cursos de graduação & 105 & 24,94 \\
\hline
\end{tabular}




\begin{tabular}{|c|c|c|}
\hline Institutos & $\begin{array}{l}\text { Qtd. } \\
\text { Curso }\end{array}$ & $\%$ \\
\hline 4 - Especialização & 33 & 7,84 \\
\hline 5 - Mestrado & 5 & 1,19 \\
\hline 6 - Doutorado & 5 & 1,19 \\
\hline $\begin{array}{l}\text { Instituto Federal de Educação, Ciência e Tecnologia do Norte de Minas } \\
\text { Gerais }\end{array}$ & 178 & 1,87 \\
\hline $1-\mathrm{FIC}$ & 12 & 6,74 \\
\hline 2 - Cursos técnicos & 92 & 51,69 \\
\hline 3 - Cursos de graduação & 64 & 35,96 \\
\hline 4 - Especialização & 8 & 4,49 \\
\hline 5 - Mestrado & 2 & 1,12 \\
\hline Instituto Federal de Educação, Ciência e Tecnologia do Pará & 558 & 5,86 \\
\hline $1-\mathrm{FIC}$ & 72 & 12,90 \\
\hline 2 - Cursos técnicos & 305 & 54,66 \\
\hline 3 - Cursos de graduação & 146 & 26,16 \\
\hline 4 - Especialização & 32 & 5,73 \\
\hline 5 - Mestrado & 3 & 0,54 \\
\hline Instituto Federal de Educação, Ciência e Tecnologia do Paraná & 247 & 2,59 \\
\hline $1-\mathrm{FIC}$ & 40 & 16,19 \\
\hline 2 - Cursos técnicos & 147 & 59,51 \\
\hline 3 - Cursos de graduação & 49 & 19,84 \\
\hline 4 - Especialização & 9 & 3,64 \\
\hline 5 - Mestrado & 1 & 0,40 \\
\hline 6 - Doutorado & 1 & 0,40 \\
\hline Instituto Federal de Educação, Ciência e Tecnologia do Piauí & 181 & 1,90 \\
\hline $1-\mathrm{FIC}$ & 28 & 15,47 \\
\hline 2 - Cursos técnicos & 102 & 56,35 \\
\hline 3 - Cursos de graduação & 49 & 27,07 \\
\hline 4 - Especialização & 1 & 0,55 \\
\hline 5 - Mestrado & 1 & 0,55 \\
\hline Instituto Federal de Educação, Ciência e Tecnologia do Rio de Janeiro & 272 & 2,86 \\
\hline $1-\mathrm{FIC}$ & 77 & 28,31 \\
\hline 2 - Cursos técnicos & 105 & 38,60 \\
\hline 3 - Cursos de graduação & 72 & 26,47 \\
\hline 4 - Especialização & 14 & 5,15 \\
\hline 5 - Mestrado & 4 & 1,47 \\
\hline $\begin{array}{l}\text { Instituto Federal de Educação, Ciência e Tecnologia do Rio Grande do } \\
\text { Norte }\end{array}$ & 438 & 4,60 \\
\hline $1-\mathrm{FIC}$ & 24 & 5,48 \\
\hline 2 - Cursos técnicos & 191 & 43,61 \\
\hline 3 - Cursos de graduação & 159 & 36,30 \\
\hline 4 - Especialização & 60 & 13,70 \\
\hline 5 - Mestrado & 4 & 0,91 \\
\hline Instituto Federal de Educação, Ciência e Tecnologia do Rio Grande do Sul & 289 & 3,04 \\
\hline $1-\mathrm{FIC}$ & 10 & 3,46 \\
\hline 2 - Cursos técnicos & 193 & 66,78 \\
\hline
\end{tabular}




\begin{tabular}{|c|c|c|}
\hline Institutos & $\begin{array}{l}\text { Qtd. } \\
\text { Curso }\end{array}$ & $\%$ \\
\hline 3 - Cursos de graduação & 82 & 28,37 \\
\hline 4 - Especialização & 4 & 1,38 \\
\hline $\begin{array}{l}\text { Instituto Federal de Educação, Ciência e Tecnologia do Sertão } \\
\text { Pernambucano }\end{array}$ & 197 & 2,07 \\
\hline $1-\mathrm{FIC}$ & 93 & 47,21 \\
\hline 2 - Cursos técnicos & 58 & 29,44 \\
\hline 3 - Cursos de graduação & 35 & 17,77 \\
\hline 4 - Especialização & 7 & 3,55 \\
\hline 5 - Mestrado & 4 & 2,03 \\
\hline $\begin{array}{l}\text { Instituto Federal de Educação, Ciência e Tecnologia do Sudeste de Minas } \\
\text { Gerais }\end{array}$ & 162 & 1,70 \\
\hline $1-\mathrm{FIC}$ & 15 & 9,26 \\
\hline 2 - Cursos técnicos & 101 & 62,35 \\
\hline 3 - Cursos de graduação & 42 & 25,93 \\
\hline 4 - Especialização & 2 & 1,23 \\
\hline 5 - Mestrado & 2 & 1,23 \\
\hline Instituto Federal de Educação, Ciência e Tecnologia do Sul de Minas Gerais & 257 & 2,70 \\
\hline $1-\mathrm{FIC}$ & 64 & 24,90 \\
\hline 2 - Cursos técnicos & 120 & 46,69 \\
\hline 3 - Cursos de graduação & 52 & 20,23 \\
\hline 4 - Especialização & 21 & 8,17 \\
\hline Instituto Federal de Educação, Ciência e Tecnologia do Triângulo Mineiro & 92 & 0,97 \\
\hline $1-\mathrm{FIC}$ & 3 & 3,26 \\
\hline 2 - Cursos técnicos & 51 & 55,43 \\
\hline 3 - Cursos de graduação & 30 & 32,61 \\
\hline 4 - Especialização & 8 & 8,70 \\
\hline Instituto Federal de Educação, Ciência e Tecnologia Farroupilha & 238 & 2,50 \\
\hline $1-\mathrm{FIC}$ & 38 & 15,97 \\
\hline 2 - Cursos técnicos & 120 & 50,42 \\
\hline 3 - Cursos de graduação & 58 & 24,37 \\
\hline 4 - Especialização & 16 & 6,72 \\
\hline 5 - Mestrado & 5 & 2,10 \\
\hline 6 - Doutorado & 1 & 0,42 \\
\hline Instituto Federal de Educação, Ciência e Tecnologia Fluminense & 291 & 3,06 \\
\hline $1-\mathrm{FIC}$ & 45 & 15,46 \\
\hline 2 - Cursos técnicos & 158 & 54,30 \\
\hline 3 - Cursos de graduação & 70 & 24,05 \\
\hline 4 - Especialização & 17 & 5,84 \\
\hline 5 - Mestrado & 1 & 0,34 \\
\hline Instituto Federal de Educação, Ciência e Tecnologia Goiano & 240 & 2,52 \\
\hline $1-\mathrm{FIC}$ & 45 & 18,75 \\
\hline 2 - Cursos técnicos & 103 & 42,92 \\
\hline 3 - Cursos de graduação & 75 & 31,25 \\
\hline 4 - Especialização & 8 & 3,33 \\
\hline 5 - Mestrado & 6 & 2,50 \\
\hline
\end{tabular}




\begin{tabular}{l|cc}
\hline Institutos & Qtd. & \\
Curso & $\%$ \\
\hline 6 - Doutorado & 3 & 1,25 \\
Instituto Federal de Educação, Ciência e Tecnologia Sul-Rio-Grandense & 175 & 1,84 \\
\hline 1 - FIC & 12 & 6,86 \\
2 - Cursos técnicos & 84 & 48,00 \\
3 - Cursos de graduação & 56 & 32,00 \\
4 - Especialização & 19 & 10,86 \\
5 - Mestrado & 4 & 2,29 \\
\hline Total Geral & 9521 & 100,00 \\
\hline
\end{tabular}

Fonte: SISTEC/MEC

\section{ANEXO III - ANÁLISE ESTATÍSTICA DAS HIPÓTESES}

\section{H1: A titulação dos professores influencia na ampliação da oferta de cursos Superiores.}

Para testar essa hipótese foi utilizada a técnica de regressão linear, a variável dependente foi a de números de matriculas nos cursos de graduação e como variável independente as variáveis (Especialização, Mestrado e Doutorado) que representam a titulação dos professores.

O quadro abaixo demonstra os impactos das variáveis na ampliação dos cursos de graduação:

Coeficientes $^{\mathbf{a}}$

\begin{tabular}{|c|c|c|c|c|c|c|c|}
\hline \multirow{2}{*}{ Modelo } & \multicolumn{2}{|c|}{$\begin{array}{l}\text { Coeficientes não } \\
\text { padronizados }\end{array}$} & \multirow{2}{*}{$\begin{array}{c}\text { Coeficientes } \\
\text { padronizados } \\
\text { Beta }\end{array}$} & \multirow{2}{*}{$\mathrm{t}$} & \multirow{2}{*}{ Sig. } & \multicolumn{2}{|c|}{$\begin{array}{c}95,0 \% \text { Intervalo de Confiança } \\
\text { para B }\end{array}$} \\
\hline & B & Erro Padrão & & & & $\begin{array}{l}\text { Limite } \\
\text { inferior }\end{array}$ & Limite superior \\
\hline (Constante) & 0,04 & 0,06 & & 0,74 & $45,84 \%$ & $-0,15$ & 0,07 \\
\hline Especialista & 0,004 & 0,05 & 0,040 & 0,67 & $0,79 \%$ & 0,060 & 0,095 \\
\hline Mestre & 0,043 & 0,05 & 0,043 & 0,96 & $5,04 \%$ & 0,060 & 0,100 \\
\hline Doutores & 0,046 & 0,08 & 0,047 & 0,82 & $41,20 \%$ & 0,06 & 0,095 \\
\hline
\end{tabular}

a. Variável Dependente: Matriculas_CG_Padronizada

Podemos observar que as variáveis Especialistas e Mestres impactam a ampliação de cursos de graduação de forma positiva, ou seja, quanto maior o número de 
mestres e especialistas maior o número de novas matriculas nos cursos de graduação.

H2: O crescimento da oferta de cursos superiores inibe o crescimento da oferta de cursos técnicos.

\begin{tabular}{|c|c|c|c|c|c|c|c|}
\hline \multirow{2}{*}{ Modelo } & \multicolumn{2}{|c|}{$\begin{array}{l}\text { Coeficientes não } \\
\text { padronizados }\end{array}$} & \multirow{2}{*}{$\begin{array}{c}\begin{array}{c}\text { Coeficientes } \\
\text { padronizados }\end{array} \\
\text { Beta }\end{array}$} & \multirow[b]{2}{*}{$t$} & \multirow{2}{*}{ Sig. } & \multicolumn{2}{|c|}{$\begin{array}{c}95,0 \% \text { Intervalo de } \\
\text { Confiança para B }\end{array}$} \\
\hline & B & Erro Padrão & & & & $\begin{array}{l}\text { Limite } \\
\text { inferior }\end{array}$ & $\begin{array}{l}\text { Limite } \\
\text { superior }\end{array}$ \\
\hline (Constante) & 0,00 & 0,05 & & 0,00 & $100,00 \%$ & $-0,11$ & 0,11 \\
\hline $\begin{array}{l}\text { Matriculas cursos } \\
\text { Técnicos }\end{array}$ & 0,36 & 0,05 & 0,36 & 6,76 & $0,00 \%$ & 0,26 & 0,47 \\
\hline
\end{tabular}

a. Variável Dependente: Matriculas Curso de Graduação

Pelo demonstrado acima quanto maior o número de matriculas nos cursos de graduação maior também será a oferta nos cursos técnicos, desse modo o aumento dos cursos de graduação não inibe a oferta de cursos técnicos.

H3: A titulação do corpo docente e a qualidade da infraestrutura laboratorial impacta positivamente na qualidade dos cursos de graduação.

Para essa análise foi construída a variável corpo docente. Essa variável é composta pelas variáveis (Especialista, Mestre e Doutores), foi feita uma análise fatorial para construir a variável Corpo docente, e posteriormente utilizamos essa variável em 
uma regressão linear para verificar o impacto dela na qualidade dos cursos de graduação.

O quadro abaixo demonstra a hipótese testada.

\begin{tabular}{|c|c|c|c|c|c|c|c|}
\hline \multirow{2}{*}{ Modelo } & \multicolumn{2}{|c|}{$\begin{array}{c}\text { Coeficientes não } \\
\text { padronizados }\end{array}$} & \multirow{2}{*}{$\begin{array}{c}\begin{array}{c}\text { Coeficientes } \\
\text { padronizados }\end{array} \\
\text { Beta }\end{array}$} & \multirow{2}{*}{$\mathrm{t}$} & \multirow{2}{*}{ Sig. } & \multicolumn{2}{|c|}{$\begin{array}{c}95,0 \% \text { Intervalo de } \\
\text { Confiança para B }\end{array}$} \\
\hline & B & $\begin{array}{c}\text { Erro } \\
\text { Padrão }\end{array}$ & & & & $\begin{array}{l}\text { Limite } \\
\text { inferior }\end{array}$ & $\begin{array}{l}\text { Limite } \\
\text { superior }\end{array}$ \\
\hline (Constante) & 0,00 & 0,06 & & 0,00 & $100,00 \%$ & $-0,11$ & 0,11 \\
\hline Corpo Docente & 0,20 & 0,06 & 0,60 & 3,49 & $0,06 \%$ & 0,09 & 0,65 \\
\hline
\end{tabular}

a. Variável Dependente: Qualidade dos cursos de graduação

Podemos observar que o corpo docente impacta positivamente a qualidade dos cursos de graduação, quanto maior a titulação do corpo docente maior a qualidade dos cursos de graduação.

Utilizou-se uma regressão linear para testar o impacto da infraestrutura na qualidade dos cursos de graduação.

\begin{tabular}{|c|c|c|c|c|c|c|c|}
\hline \multirow{2}{*}{ Modelo } & \multicolumn{2}{|c|}{$\begin{array}{l}\text { Coeficientes não } \\
\text { padronizados }\end{array}$} & \multirow{2}{*}{$\begin{array}{c}\text { Coeficientes } \\
\text { padronizados } \\
\text { Beta }\end{array}$} & \multirow{2}{*}{$\mathrm{t}$} & \multirow{2}{*}{ Sig. } & \multicolumn{2}{|c|}{$\begin{array}{c}95,0 \% \text { Intervalo de Confiança } \\
\text { para B }\end{array}$} \\
\hline & B & Erro Padrão & & & & Limite inferior & Limite superior \\
\hline (Constante) & 0,00 & 0,06 & & 0,05 & $95,94 \%$ & $-0,11$ & 0,11 \\
\hline Infraestrutura & 0,22 & 0,05 & 0,53 & 4,03 & $0,01 \%$ & 0,11 & 0,60 \\
\hline
\end{tabular}

a. Variável Dependente: Qualidade dos cursos de graduação

\section{H4: A titulação do corpo docente e a qualidade da infraestrutura laboratorial impacta positivamente na Produção Científica.}

O mesmo raciocínio relacionado à análise da hipótese anterior foi aplicado a está, ou seja, primeiramente foi construída a variável corpo docente. Essa variável é composta pelas variáveis (Especialista, Mestre e Doutores), foi feita uma análise fatorial para construir a variável Corpo docente, e posteriormente utilizamos essa variável em uma regressão linear para verificar o impacto dela na atividade de 
pesquisa.

O quadro abaixo demonstra a hipótese testada.

\begin{tabular}{|c|c|c|c|c|c|c|c|}
\hline \multirow{2}{*}{ Modelo } & \multicolumn{2}{|c|}{$\begin{array}{c}\text { Coeficientes não } \\
\text { padronizados }\end{array}$} & \multirow{2}{*}{$\begin{array}{c}\begin{array}{c}\text { Coeficientes } \\
\text { padronizados }\end{array} \\
\text { Beta }\end{array}$} & \multirow{2}{*}{$\mathrm{t}$} & \multirow{2}{*}{ Sig. } & \multicolumn{2}{|c|}{$\begin{array}{c}95,0 \% \text { Intervalo de } \\
\text { Confiança para B }\end{array}$} \\
\hline & B & $\begin{array}{c}\text { Erro } \\
\text { Padrão }\end{array}$ & & & & $\begin{array}{l}\text { Limite } \\
\text { inferior }\end{array}$ & $\begin{array}{l}\text { Limite } \\
\text { superior }\end{array}$ \\
\hline (Constante) & 0,00 & 0,06 & & 0,00 & $100,00 \%$ & $-0,11$ & 0,11 \\
\hline Corpo Docente & 0,20 & 0,06 & 0,20 & 3,49 & $0,06 \%$ & 0,09 & 0,31 \\
\hline
\end{tabular}

a. Variável Dependente: Produção Científica

Podemos observar que o corpo docente impacta positivamente a atividade de pesquisa, quanto maior a titulação do corpo docente maior a atividade de pesquisa.

Utilizou-se uma regressão linear para testar o impacto da infraestrutura na produção científica os resultados estão demonstrados no quadro abaixo.

\begin{tabular}{|c|c|c|c|c|c|c|c|}
\hline \multirow{2}{*}{ Modelo } & \multicolumn{2}{|c|}{$\begin{array}{l}\text { Coeficientes não } \\
\text { padronizados }\end{array}$} & \multirow{2}{*}{$\begin{array}{c}\begin{array}{c}\text { Coeficientes } \\
\text { padronizados }\end{array} \\
\text { Beta }\end{array}$} & \multirow{2}{*}{$\mathrm{t}$} & \multirow{2}{*}{ Sig. } & \multicolumn{2}{|c|}{$\begin{array}{c}95,0 \% \text { Intervalo de Confiança } \\
\text { para B }\end{array}$} \\
\hline & B & Erro Padrão & & & & Limite inferior & Limite superior \\
\hline (Constante) & 0,00 & 0,06 & & 0,05 & $95,94 \%$ & $-0,11$ & 0,11 \\
\hline Infraestrutura & 0,22 & 0,05 & 0,23 & 4,03 & $0,01 \%$ & 0,11 & 0,33 \\
\hline
\end{tabular}

a. Variável Dependente: Produção Científica

\section{H5: O entorno produtivo local exerce impacto positivo na produção científica.}

Para testar essa hipótese optou-se por utilizar uma regressão linear, no qual a variável explicativa era o entorno produtivo e a variável dependente a produção científica, o intuito é verificar o impacto do entorno produtivo na produção científica. No quadro abaixo podemos verificar o impacto do entorno produtivo na produção científica: 


\begin{tabular}{|l|c|c|c|c|c|c|c|}
\multirow{2}{*}{ Modelo } & \multicolumn{2}{|c|}{$\begin{array}{c}\text { Coeficientes não } \\
\text { padronizados }\end{array}$} & $\begin{array}{c}\text { Coeficientes } \\
\text { padronizados }\end{array}$ & \multirow{2}{*}{$t$} & \multirow{2}{*}{ Sig. } & \multicolumn{2}{|c|}{$\begin{array}{c}95,0 \% \text { Intervalo de } \\
\text { Confiança para B }\end{array}$} \\
\cline { 2 - 4 } & $\mathrm{B}$ & Erro Padrão & Beta & & & $\begin{array}{c}\text { Limite } \\
\text { inferior }\end{array}$ & $\begin{array}{c}\text { Limite } \\
\text { superior }\end{array}$ \\
\hline (Constante) & $-0,011$ & 0,057 & & $-0,199$ & $84,20 \%$ & $-0,123$ & 0,101 \\
\hline Entorno Produtivo & 0,4 & 0,06 & 0,070 & 0,0 & $5,00 \%$ & $-0,237$ & 0,82 \\
\hline
\end{tabular}

a. Variável Dependente: Produção Científica

No quadro acima podemos notar que a variável Entorno Produtivo não exerce um impacto positivo sobre a produção científica.

H6: A maior especialização do Instituto (menor número de eixos ofertados) influencia o aumento na produção científica.

Para testar essa hipótese optou-se por utilizar uma regressão linear, no qual a variável explicativa era o número de eixos do curso técnico e a variável dependente a produção científica, o intuito é verificar o impacto do número de eixos de cursos técnicos ofertados na produção científica.

No quadro a baixo podemos verificar o impacto desses eixos na produção científica:

\begin{tabular}{|c|c|c|c|c|c|c|c|}
\hline \multirow{2}{*}{ Modelo } & \multicolumn{2}{|c|}{$\begin{array}{l}\text { Coeficientes não } \\
\text { padronizados }\end{array}$} & \multirow{2}{*}{$\begin{array}{c}\text { Coeficientes } \\
\text { padronizados } \\
\text { Beta }\end{array}$} & \multirow{2}{*}{$\mathrm{t}$} & \multirow{2}{*}{ Sig. } & \multicolumn{2}{|c|}{$\begin{array}{c}95,0 \% \text { Intervalo de } \\
\text { Confiança para B }\end{array}$} \\
\hline & B & Erro Padrão & & & & $\begin{array}{l}\text { Limite } \\
\text { inferior }\end{array}$ & $\begin{array}{l}\text { Limite } \\
\text { superior }\end{array}$ \\
\hline (Constante) & 0,00 & 0,06 & & 0,00 & $100,00 \%$ & $-0,11$ & 0,11 \\
\hline $\begin{array}{l}\text { Eixos Cursos } \\
\text { Técnicos }\end{array}$ & 0,002 & 0,06 & 0,002 & $-0,65$ & $51,39 \%$ & $-0,15$ & 0,08 \\
\hline
\end{tabular}

a. Variável Dependente: produção científica

Como podemos observar o Eixo de cursos técnicos não causa nenhum efeito na atividade de pesquisa, a hipótese foi rejeitada.

\section{H7: O contexto educativo influencia positivamente a quantidade e diversidade de cursos ofertados (técnicos e Tecnológicos).}


Com o intuito de testar a hipótese foi feito uma regressão no qual a variável dependente utilizada foi (Diversidade de Cursos Técnicos - Eixos de Cursos Técnicos) e as variáveis dependentes (IDEB e IDHM).

\begin{tabular}{|l|c|c|c|c|c|c|c|}
\multirow{2}{*}{ Modelo } & \multicolumn{2}{|c|}{$\begin{array}{c}\text { Coeficientes não } \\
\text { padronizados }\end{array}$} & $\begin{array}{c}\text { Coeficientes } \\
\text { padronizados }\end{array}$ & \multirow{2}{*}{$\mathrm{t}$} & \multirow{2}{*}{ Sig. } & \multicolumn{2}{|c|}{$\begin{array}{c}95,0 \% \text { Intervalo de } \\
\text { Confiança para B }\end{array}$} \\
\cline { 2 - 3 } & $\mathrm{B}$ & Erro Padrão & Beta & & & $\begin{array}{c}\text { Limite } \\
\text { inferior }\end{array}$ & $\begin{array}{c}\text { Limite } \\
\text { superior }\end{array}$ \\
\hline (Constante) & 0,004652 & 0,056979481 & & 0,081638 & $93,50 \%$ & $-0,10748$ & 0,116785 \\
\hline IDEB & 0,23782 & 0,06017716 & 0,23 & 1,980974 & $89,66 \%$ & $-0,12625$ & 0,110603 \\
IDHM & 0,154412 & 0,06025221 & 0,28 & 2,562763 & $1,09 \%$ & 0,035838 & 0,272986 \\
\hline
\end{tabular}

a. Variável Dependente: Eixos_CT_Padronizado

A Tabela acima demonstra que tanto o IDEB quanto o IDHM causam impacto positivo na diversidade de cursos técnicos.

\section{H8: A diversidade da oferta de cursos (técnicos e tecnológicos) influencia na inserção laboral dos egressos.}

Para testar essa hipótese foi construída a variável "Egresso qualificado para o trabalho", utilizamos as variáveis: Cursos de Graduação, Cursos Técnicos e Atividade de Pesquisa, conforme demonstrado no quadro enviado essa variável (Egresso Qualificado) não é mensurável e provem das três variáveis citadas, foi utilizada uma análise fatorial para a construção dessa variável não observada.

\begin{tabular}{|c|c|c|c|c|c|c|c|}
\hline \multirow{2}{*}{ Modelo } & \multicolumn{2}{|c|}{$\begin{array}{c}\text { Coeficientes não } \\
\text { padronizados }\end{array}$} & \multirow{2}{*}{$\begin{array}{c}\begin{array}{c}\text { Coeficientes } \\
\text { padronizados }\end{array} \\
\text { Beta }\end{array}$} & \multirow{2}{*}{$\mathrm{t}$} & \multirow{2}{*}{ Sig. } & \multicolumn{2}{|c|}{$\begin{array}{c}95,0 \% \text { Intervalo de } \\
\text { Confiança para B }\end{array}$} \\
\hline & B & $\begin{array}{c}\text { Erro } \\
\text { Padrão }\end{array}$ & & & & $\begin{array}{l}\text { Limite } \\
\text { inferior }\end{array}$ & $\begin{array}{l}\text { Limite } \\
\text { superior }\end{array}$ \\
\hline (Constante) & 0,00 & 0,04 & & 0,00 & $100,00 \%$ & $-0,08$ & 0,08 \\
\hline Eixos Cursos Técnicos & 0,74 & 0,04 & 0,74 & 19,24 & $0,00 \%$ & 0,67 & 0,82 \\
\hline
\end{tabular}

a. Variável Dependente: Egresso qualificado ao mercado de Trabalho 
Como observado no quadro acima a diversidade de curso técnico influência de forma significativa e positiva o egresso qualificado para o trabalho.

\section{H9: A qualidade da infraestrutura associada ao entorno produtivo impacta positivamente a empregabilidade do egresso.}

Com o intuito de verificar o impacto da variável infraestrutura com a variável entorno produtivo na variável egresso qualificado para o trabalho, foi construída uma variável nova que é a junção dessas duas variáveis. A análise utilizada foi uma regressão linear a variável dependente utilizada foi a Egresso qualificado e as variáveis explicativas (Entorno Produtivo, Infraestrutura, Entorno produtivo * Infraestrutura).

\begin{tabular}{|c|c|c|c|c|c|c|c|}
\hline \multirow{2}{*}{ Modelo } & \multicolumn{2}{|c|}{$\begin{array}{c}\text { Coeficientes não } \\
\text { padronizados }\end{array}$} & \multirow{2}{*}{$\begin{array}{c}\begin{array}{c}\text { Coeficientes } \\
\text { padronizados }\end{array} \\
\text { Beta }\end{array}$} & \multirow{2}{*}{$\mathrm{t}$} & \multirow{2}{*}{ Sig. } & \multicolumn{2}{|c|}{$\begin{array}{c}95,0 \% \text { Intervalo de } \\
\text { Confiança para B }\end{array}$} \\
\hline & B & Erro Padrão & & & & $\begin{array}{l}\text { Limite } \\
\text { inferior }\end{array}$ & $\begin{array}{l}\text { Limite } \\
\text { superior }\end{array}$ \\
\hline (Constante) & $-0,02$ & 0,05 & & $-0,30$ & $76,09 \%$ & $-0,12$ & 0,09 \\
\hline $\begin{array}{l}\text { Entorno Produtivo } \mathrm{x} \\
\text { Infraestrutura }\end{array}$ & 0,13 & 0,06 & 0,12 & 2,40 & $1,72 \%$ & 0,02 & 0,24 \\
\hline $\begin{array}{l}\text { Infraestrutura } \\
\text { Padronizada }\end{array}$ & 0,22 & 0,05 & 0,23 & 4,32 & $0,00 \%$ & 0,12 & 0,32 \\
\hline Entorno Produtivo & 0,33 & 0,05 & 0,33 & 6,29 & $0,00 \%$ & 0,23 & 0,43 \\
\hline
\end{tabular}

a. Variável Dependente: Egresso qualificado ao mercado de Trabalho

Como podemos observar, a infraestrutura associada ao entorno produtivo impacta positivamente a egresso qualificado ao mercado de trabalho, podemos também verificar que tanto a infraestrutura quanto 0 entorno produtivo analisado separadamente impactam o egresso qualificado. 